\title{
Universiteit
}

Leiden

The Netherlands

\section{Negotiating an Anglophone identity: a study of the politics of recognition and representation in Cameroon}

Konings, P.J.J.; Nyamnjoh, F.B.

\section{Citation}

Konings, P. J. J., \& Nyamnjoh, F. B. (2003). Negotiating an Anglophone identity: a study of the politics of recognition and representation in Cameroon. Leiden: Brill. Retrieved from https://hdl.handle.net/1887/12878

Version:

Not Applicable (or Unknown)

License: $\quad$ Leiden University Non-exclusive license

Downloaded from: $\quad$ https://hdl.handle.net/1887/12878

Note: To cite this publication please use the final published version (if applicable). 
Negotiating an Anglophone Identity 


\title{
Afrika-Studiecentrum Series
}

\author{
Editorial Board
}

Prof. Nicolas van de Walle (Michigan State University, USA)

Prof. Deborah Posel (Director WISER, South Africa)

Dr Ruth Watson (University of London, UK)

Dr Paul Mathieu (FAO, Rome)

Dr Piet Konings (African Studies Centre)

VOLUME 1 


\section{Negotiating an \\ Anglophone Identity}

\section{A Study of the Politics of Recognition and \\ Representation in Cameroon}

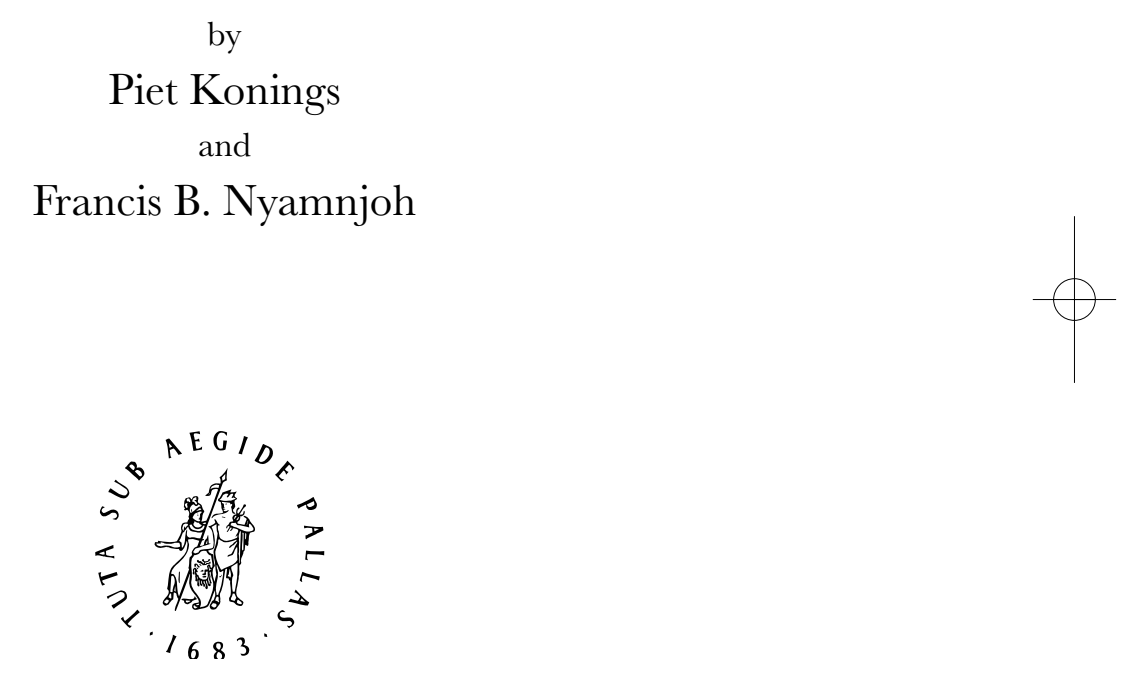

BRILL

LEIDEN $\cdot$ BOSTON

2003 
This book is printed on acid-free paper.

\section{Library of Congress Cataloging-in-Publication Data}

Konings, Piet.

Negotiating an Anglophone identity : a study of the politics of recognition and representation in Cameroon / by Piet Konings and Francis B. Nyamnjoh.

p. cm. - (Afrika-Studiecentrum series, ISSN 1570-9310 ; v. 1)

Includes bibliographical references and index.

ISBN 90-04-13295-3 (pbk. : alk. paper)

1. Cameroon-Languages - Political aspects. 2. English language-Political aspects - Cameroon. 3. Cameroon-Politics and government-1960-I. Nyamnjoh Francis B., $1961-$ II. Title. III. Series.

P119.32.C17K66 2003

306.44 ’ $6711-\mathrm{dc} 21$

2003049588

ISSN $\quad 1570-9310$

ISBN 9004132953

\section{(C) Copyright 2003 by Koninklijke Brill NV, Leiden, The Netherlands}

Cover design by Thorsten's Celine Ostendorf

All rights reserved. No part of this publication may be reproduced, translated, stored in a retrieval system, or transmitted in any form or by any means, electronic, mechanical, photocopying, recording or otherwise, without prior written permission from the publisher.

Authorization to photocopy items for internal or personal use is granted by Brill provided that the appropriate fees are paid directly to The Copyright

Clearance Center, 222 Rosewood Drive, Suite 910 Danvers, MA 01923, USA.

Fees are subject to change.

PRINTED IN THE NETHERLANDS 


\section{Contents}

Acknowledgements vii

Abbreviations viii

1. POLITICAL LIBERALISATION AND THE MOBILISATION OF AN ANGLOPHONE IDENTITY IN CAMEROON 1

The post-colonial nation-state project in Cameroon 2

The construction of an Anglophone identity and competing identities 9

Anglophones and the reconfiguration of state power 17

Organisation of the book and research methodology 20

2. SOUTHERN CAMEROONS ON THE ROAD TO REUNIFICATION AND FEDERATION 22

The emergence of nationalism and reunification ideas in the Southern Cameroons 23

The 1961 United Nations plebiscite 31

The 1961 Foumban constitutional conference 41

Conclusion 48

3. THE DEVELOPMENT OF AN ANGLOPHONE CONSCIOUSNESS DURING

THE FEDERAL AND ONE-PARTY UNITARY STATE, 1961-1990 51

Anglophones and the dismantling of the federated state of

West Cameroon, 1961-1972 52

Anglophones and the one-party unitary state, 1972-1990 66

Conclusion 74

4. ANGLOPHONE STRUGGLES FOR A RETURN TO THE FEDERAL STATE

OR FOR SECESSION DURING POLITICAL LIBERALISATION, 1990-2002 76

The growth of Anglophone organisations 77

Anglophone struggles for constitutional reform $\quad 82$

The Anglophone diplomatic offensive 94

The Anglophone leadership's 'sensitisation campaign' 101

Conclusion 106

5. STRATEGIES OF THE BIYA GOVERNMENT TO DECONSTRUCT

THE ANGLOPHONE IDENTITY 108

Trivialisation and demonisation of the Anglophone problem 109

Divide and rule 111

The establishment of direct and indirect control over the mass media

Repression 133

Conclusion 136 
6. ANGLOPHONE AND FRANCOPHONE RESPONSES TO THE VIEWS OF THE ANGLOPHONE MOVEMENTS 139

Anglophone views 140

Francophone views 153

Conclusion 161

7. THE ANGLOPHONE STRUGGLE FOR THE PRESERVATION

OF ITS EDUCATIONAL AND ECONOMIC LEGACY 162

The Anglophone struggle for the preservation of its educational legacy 163

The Anglophone struggle for the preservation of its economic legacy $\quad 173$ Conclusion 191

8. THE ANGLOPHONE PROBLEM:

IMPASSE AND SUGGESTIONS FOR A SOLUTION 193

Impasse in relations between Anglophone movements and the regime 193

Suggestions for a solution to the Anglophone problem 202

References 209

Index 223 


\section{Acknowledgements}

During our fieldwork in Cameroon we became indebted to a great number of people and unfortunately there is room to mention only a few of them here. We are particularly grateful to the leaders of the various Anglophone movements who spent much of their precious time giving us an insight into the aims and strategies of their organisations. We highly appreciated the assistance offered by Prince Henry Mbayn of the Buea National Archives who provided us with access to relevant archives, papers and documents. We also benefited from the regular advice and support of some Cameroonian colleagues, especially Benedict Nantang Jua, Nicodemus Fru Awasom and Lucien Mufor Atanga. They have been a constant source of friendship and intellectual stimulation.

We would like to express our gratitude to the African Studies Centre in Leiden, which not only funded the entire project but also offered an eight-month visiting fellowship to Francis Nyamnjoh to allow this joint project to come to fruition.

Finally, we wish to thank Ann Reeves for copy-editing the text and Mieke Zwart for the lay-out work. 


\section{Abbreviations}

\begin{tabular}{|c|c|}
\hline AAC & All Anglophone Conference \\
\hline AM & Ambazonian Movement \\
\hline AMENORD & Amicale des Elites du Nord \\
\hline BLCC & Bakweri Land Claim Committee \\
\hline BNA & Buea National Archives \\
\hline BPI & Buea Peace Initiative \\
\hline CAM & Cameroon Anglophone Movement \\
\hline CAMASEJ & Cameroon Association of English-Speaking Journalists \\
\hline CANSA & Cameroon Anglophone Students' Association \\
\hline CAPSU & Cameroon Anglophone Public Servants' Union \\
\hline CAPTAC & $\begin{array}{l}\text { Confederation of Anglophone Parent Teacher Associations of } \\
\text { Cameroon }\end{array}$ \\
\hline $\mathrm{CBC}$ & Cameroon Baptist Convention \\
\hline $\mathrm{CCC}$ & Cameroons Commoners' Congress \\
\hline CCCE & $\begin{array}{l}\text { Central Fund for Economic Cooperation/Caisse Centrale de } \\
\text { Coopération Economique }\end{array}$ \\
\hline $\mathrm{CDC}$ & Cameroon Development Corporation \\
\hline CDU & Cameroon Democratic Union \\
\hline CFA & Communauté Financière Africaine \\
\hline CIP & Cameroon Indigenes Party \\
\hline $\mathrm{CNF}$ & Cameroon National Federation \\
\hline $\mathrm{CNU}$ & Cameroon National Union \\
\hline COMDEV & Commonwealth Development Corporation \\
\hline $\mathrm{CPC}$ & Congrès Panafricain du Cameroun \\
\hline CPDM & Cameroon People's Democratic Movement \\
\hline CPNC & Cameroon People's National Congress \\
\hline CRP & Conservative Republican Party \\
\hline CRTV & Cameroon Radio and Television \\
\hline CUC & Cameroon United Congress \\
\hline CYL & Cameroon's Youth League \\
\hline DCK & Dynamique Culturelle Kirdi \\
\hline
\end{tabular}


ECOSOG United Nations Economic and Social Council

FAC

Front of Allies for Change

FCWU

French Cameroon's Welfare Union

FEDO

FRSC

Fako Elite Development Organisation

FWCM

Federal Republic of Southern Cameroons

GCE

Free West Cameroon Movement

IDA

General Certificate of Education

IMF

International Development Association

KNC

International Monetary Fund

KNDP

Kamerun National Convention

KPP

Kamerun National Democratic Party

KUNC

Kamerun People's Party

KUP

Kamerun United National Congress

LDA

Kamerun United Party

LDP

Liberal Democratic Alliance

MDP

Liberal Democratic Party

MINAT

Mouvement pour la Démocratie Populaire

MOREPAH

Ministry of Territorial Administration

MP

Mouvement de Renaissance Pahwin

NDP

Mouvement Progressive

$\mathrm{NGO}$

National Democratic Party

NOCUDA

Non-Governmental Organisation

NOWEDA

North West Cultural and Development Association

NOWEFA

NOWEFCO

NUDP

OAU

North West Development Association

North West Fons' Association

North West Fons' Conference

National Union of Democracy and Progress

Organisation of African Unity

PAL

Parti de l'Alliance Libérale

PCC

Presbyterian Church in Cameroon

PSP

PTA

Parti de Solidarité du Peuple

RCC

Parent-Teacher Association

SAP

Roman Catholic Church

SCAC

Structural Adjustment Programme

Southern Cameroons Advisory Council

SCARM

Southern Cameroons Restoration Movement

$\mathrm{SCNC}$

Southern Cameroons National Council 
SCPC

SCYL

SDF

SDP

SONARA

SONEL

SWECC

SWELA

TAC

$\mathrm{UC}$

UDC

UFDC

UN

UNGA

UNPO

UPC
Southern Cameroons People's Conference

Southern Cameroons Youth League

Social Democratic Front

Social Democratic Party

Société Nationale de Raffinage

Société Nationale d'Electricité

South West Chiefs' Conference

South West Elite Association

Teachers' Association of Cameroon

Union Camerounaise

Union Démocratique du Cameroun

Union des Forces Démocratiques du Cameroun

United Nations

United Nations General Assembly

Unrepresented Nations and Peoples Organisation

Union des Populations du Cameroun 


\section{Political liberalisation and the mobilisation of an Anglophone identity in Cameroon}

As in other parts of the world, political liberalisation in Cameroon has been marked by the construction and mobilisation of ethno-regional identities that pose a major challenge to the post-colonial nation-state project (cf. McGarry \& O’Leary 1993; Rothchild 1997; Zognong \& Mouiche 1997). The unitary approach to the nation-state project was the predominant choice of African leaders in the decades following independence (Wunsch \& Olowu 1990). Usually this amounted to a continuation of the colonial state's nation-building programme, the primary concern of which had been to integrate the diverse ethno-regional groups into the state and place them under one centralised authority. It was seen as a sine qua non for avoiding administrative chaos and civil war and for achieving rapid development in Africa (Olukoshi \& Laakso 1996). Today it is generally agreed that this approach fostered political monolithism and authoritarianism at the expense of constitutionalism. Alternative constitutional arrangements - notably federalism, which according to Elaigwu \& Orunsola (1983: 282) 'basically emanates from the desire of people to form a union without necessarily losing their various identities' - were either ignored or consciously violated by African leaders or, as in Nigeria, they experienced an increasing concentration of power in the federal centre (Thomas-Woolley \& Keller 1994; Woodward \& Forsyth 1994; Olukoshi \& Agbu 1997). In the 
current processes of liberalisation in Africa, highly centralised unitary states are facing a serious crisis of legitimacy.

In this book we focus on Anglophone Cameroon, which has been at the forefront of ethno-regional protests and demands for the rearrangement of state power. There is a widespread feeling in this region that reunification with Francophone Cameroon in 1961 has led to a growing marginalisation of the Anglophone minority in the nation-state project controlled by the Francophone political elite, endangering its cultural heritage and identity. It was not until the political liberalisation process in the early 1990s that the Anglophone elite began to mobilise the regional population against the allegedly subordinated position of Anglophones and to demand self-determination and autonomy, reintroducing federalism and secession to the political agenda. It soon became evident, however, that the Anglophone elite was divided, offering conflicting explanations for the origin of and proposals for redressing the so-called 'Anglophone problem' (Eyoh 1998a: 249). This cleavage within the Anglophone elite can be largely attributed to ethno-regional divisions and tensions within the Anglophone community itself, particularly between South West Province (the coastal forest area) and the inland-savannah area (the so-called Grassfields), now North West Province (see Map 1).

The post-colonial state has often taken advantage of existing contradictions within the Anglophone community to play off the southwestern elite against its northwestern counterpart in persistent efforts to bolster the unitary state and to deconstruct the Anglophone identity.

In the first section of this introductory chapter, we provide a description of the Cameroonian post-colonial state's nation-state project. In the second section we argue that the colonial borders, reunification, and the post-colonial state's nation-state project are responsible for the construction of the Anglophone and competing identities. In the third section we discuss the various options for a reconfiguration of power proposed by the Anglophone and Francophone elite within the post-colonial state. In the fourth section we explain the organisation of the book and our research methodology.

\section{The post-colonial nation-state project in Cameroon}

Like many former colonies in Africa, Cameroon faced a difficult political set of circumstances at independence and reunification. Two territories, inherited from British and French colonial rule and with different cultural legacies, languages and levels of economic development, needed to be merged. There was the problem of cultural pluralism and ethnic fragmentation as evidenced by the 
coexistence of Islam and Christianity alongside indigenous systems of beliefs and the presence of more than 200 ethnic groups. And, last but not least, a bloody and destructive civil war was taking place at the time of independence and reunification in present-day Littoral and West Provinces as a direct consequence of determined efforts by the government and the French to suppress the radical nationalist party, the Union des Populations du Cameroun (UPC) (Joseph 1977). This was an indication that France would only settle for a token independence that would not upset French interests in the territory.

The challenge of constructing a nation-state lay with Ahmadou Ahidjo, who used to be prime minister (in 1958) and president (in 1960) of Francophone Cameroon before becoming the first president of the Federal Republic of Cameroon in 1961. He was a Muslim and a Fulbe, the dominant ethnic group in northern Cameroon (Azarya 1978; Schilder 1994). Initially, he was considered by many to be a mere puppet of the French and he enjoyed very little support in the southern part of the country, which had been more exposed to colonial capitalism, education and Christianity than the north (Bayart 1979). Soon, however, Ahidjo was to display an unexpected political craftsmanship that would enable him to strengthen his originally weak position and eventually to construct a system of personal rule (Gaillard 1994). Nation-building, or national unity, provided ideological support for concentrating political and economic power in his office and person (Fogui 1990). Centralisation, coalition-building and repression were his major strategies in achieving his aim (DeLancey 1989; Derrick 1992; Van de Walle 1993; Konings 1996a).'

The first strategy, centralisation, had numerous aspects. There was the introduction of a highly centralised form of federation, the concentration of administrative decision-making in the capital, Yaoundé, and the use of the constitution to focus authority in the office of the president. In addition, there was the formation of a single party, the Cameroon National Union (CNU), which was completed in 1966 after a two-step process to forge a single party in the Francophone region, and then its merger with the remaining parties of the Anglophone region. There was also the dissolution of the federation in 1972 to form a unitary system of government. Centralisation was enhanced by the elimination of autonomous forms of organisation. Previously independent organisations became subordinated to the political party through the party's women's, youth and labour wings or through domination by, or incorporation into, government agencies (as had occurred with the Anglophone cooperative movement). Related to this were policies to destroy any limited autonomy

\footnotetext{
Such strategies form the core of what McGeary \& O'Leary (1993: 23) call 'hegemonic control', one of the most common forms of managing ethnic diversity and conflict.
} 
enjoyed either by local governments (more a reality in Anglophone Cameroon) or traditional governments.

The second strategy was coalition-building. In his masterful study of the Cameroonian post-colonial state, Bayart (1979) highlighted Ahidjo's pursuit of building a hegemonic alliance out of different elite groups at the national and regional levels. This hegemonic alliance was comprised not only of politicians, bureaucrats and businessmen but equally of the traditional elite, the chiefs, and was pulled together by, among other means, the development of an extensive patron-client system. Clients were supposed to owe ultimate and total allegiance to Ahidjo, and any attempt to build their own power base was construed as betrayal and sanctioned removal from office. Ahidjo selected his clients on the basis of ethnic arithmetic or ethnic balancing (Ngayap 1983; Nkwi \& Nyamnjoh 1997). He was conscious that representation in the cabinet, national assembly and so on would reflect the various ethnic groups in society. As a matter of fact, the government's hand-picked elite or barons served as transmission belts between the president and the different ethnic groups. Thus all the important ethnic groups felt represented within the regime and were able to influence government policy (Jua 1991: 162-70; Van de Walle 1993). Paradoxically, while the politics of ethnic balance served to manage ethnic diversity and conflict, it actually tended to create an acute, sustained awareness of ethnic belonging and regional affiliation. It engraved on the minds of Cameroonians the notion that access to state functions depended not primarily on competence and merit but instead on one's strategic ethnic and regional affiliations (Monga 2000; Nyamnjoh 1999; Eyoh 1998a and b).

Loyal followers in the ethno-client network were rewarded with appointments and nominations to state offices, access to state resources, and rentseeking appointments. Beyond the numerous appointments Ahidjo could make to the cabinet and the system at large, he had a variety of other techniques to allow individuals to benefit, even though they might not receive a lucrative appointment. For some of the president's associates there were special interestfree bank loans that they were not expected to repay, and smuggling and corruption provided a major avenue for the president to allow supporters to receive rewards. Special efforts were also made to appease and maintain support among civil servants and bureaucrats. They received excellent salaries compared to the average income of Cameroonian citizens, as well as numerous perks including free housing and various degrees of impunity in the face of the law. They were allowed to convert their posts into monopoly rent-seeking opportunities and they considered the state a resource base from which various pathways of capital accumulation could be explored (Geschiere \& Konings 1993). State expansion, particularly in the economic arena, was promoted to manipulate and sustain the alliance but it would be wrong to argue that rent- 
seeking and patronage were the only reasons the government promoted state expansion after independence. Extensive public ownership conformed to prevailing development doctrines, was warmly supported by donors, and responded to real development needs. Still, the scope that state ownership was to achieve (by 1988 the state had more than 150 parastatals in its portfolio) was helped by the fact that it afforded leaders like Ahidjo positions of power to distribute. In the context of the patrimonial state, these parastatals were converted into prebends for directors-general or to serve other exclusive interests of the hegemonic class (Joseph 1978).

While Ahidjo constantly emphasised the need for ethnic balance and national unity, there is nevertheless sufficient evidence to suggest that three elite ethnic groups enjoyed a privileged position regarding capital accumulation. There was, first of all, the Muslim Fulbe elite, especially those who originated from Garoua, Ahidjo's home town, the so-called 'Garoua barons'. Second, there were the members of the Christian Beti elite from the southern part of Francophone Cameroon who formed the core of the bureaucratic-administrative faction of the hegemonic alliance on the basis of their high educational qualifications. The Fulbe-Beti axis constituted the regime's major ethnic underpinning. And thirdly, there were the members of the Bamileke elite from the Francophone part of the Grassfields, the present-day West Province. They are renowned in Cameroon for their entrepreneurial ethos (Warnier 1993; Tabapssi 1999) and it was widely believed that Ahidjo was ready to grant the Bamileke elite ample room for capital accumulation on condition that they did not meddle in politics. Ultimately, in spite of the incentives for cooperation and agreement used by Ahidjo, the stability of the regime was based on the widespread use of repression and the suppression of human rights.

The regime's apparent political stability, its lack of ideological posturing and its liberal investment code appealed to Western donors and business circles. With an annual growth rate of some 6-7 per cent between 1970 and 1985, the Cameroonian economy was considered one of Sub-Saharan Africa's success stories. It should, however, be pointed out that the country's seemingly impressive growth rate during this period was inflated by the discovery of oil in the Anglophone part of Cameroon. Strikingly, oil output and oil revenues remained a state secret throughout Ahidjo's administration. ${ }^{2}$ Apparently, most oil revenues were placed in foreign banks as 'extra-budgetary accounts'. The official justification given by Ahidjo for this strategy was the elimination of the boom

2 Under Ahidjo's successor, Paul Biya, there has been little change in this respect. Anglophones have been repeatedly incensed by his arrogant declarations that oil revenues and statistics are too complex to be understood by ordinary Cameroonians and that no one had the need to concern themselves with such figures. 
mentality that had crippled agricultural production in other African countries following the discovery of oil. Nevertheless, to conform with the regime's patrimonial logic, the primary functions of these extra-budgetary accounts were soon to cover parastatal deficits (Van de Walle 1993; Jua 1993) and to bolster the personal foreign bank accounts of the president and some of his privileged collaborators.

Ahidjo voluntarily resigned from the presidency in 1982 and was succeeded by Paul Biya, his prime minister since 1975. Unlike Ahidjo, Biya was a Christian Beti. ${ }^{3}$ This political transition did not presage fundamental alterations in state-society relations, as patronage and repression remained the main props of state power. The most conspicuous aspect of the change was the ethnoregional realignment at the summit of state power. An abortive coup in 1984, in which Ahidjo and senior northern politicians were rumoured to be implicated, provided Biya the opportunity to remove from office a number of ministers, bureaucrats and politicians who were closely associated with the Ahidjo regime or whose loyalties to the new regime were suspect. In 1984, the single party, the CNU, was renamed the Cameroon People's Democratic Movement (CPDM), with Biya in firm control (Takougang \& Krieger 1998). Despite the regime's continuous emphasis on national integration (Biya 1987), there was an increasing monopolisation of economic and political power by Biya's ethnic group, the Beti. This was a significant reversal of Ahidjo's policy of ethnic balance and formed a threat to political stability. To contain any possible challenges to its grip on power by Fulbe political barons, the Biya regime carved up the north into three administrative provinces (Adamawa, North and Far North). With this, the regime turned to a greater reliance on politicians from northern minority ethnic groups (misleadingly lumped together as 'Kirdi') as its support base in these provinces (Schilder 1994; Burnham 1996; Logo 1999). Fulbe and Bamileke businessmen, who had enjoyed a privileged position during Ahidjo's administration, were increasingly replaced by Beti businessmen (often officially backed and generously supported financially), the so-called Beti Mafia. In protest at such discrimination, Bamileke businessmen withdrew their savings from the banks and transferred them to informal saving circuits called tontines (Henry et al. 1991). This contributed to the growing liquidity problems facing banks. The Biya regime increased the number of civil servants from about 80,000 in 1982 to about 180,000 in 1988 , the majority of the new employees having been recruited among the Beti. Some of them were ghost workers - a

3 It is important to emphasise here that the name 'Beti' as an ethnic label is a historically circumscribed construct and subject to constant change. Since the 1980s the term has come to cover a number of ethnic groups in the Centre and South Provinces of Cameroon, in particular the Bulu and Eton or Ewondo. President Biya belongs to the Bulu group. 
problem that would occasion repeated censuses of civil servants under the supervision of the International Monetary Fund (IMF) and the World Bank. The Beti also increasingly monopolised pivotal positions in government and in the security forces. Takougang (1993: 95-96) reported that, as of August 1991, thirty-seven of the forty-seven senior prefects (heads of administrative divisions), three-quarters of the directors and general managers of parastatal corporations in the country, and twenty-two out of the thirty-eight high-ranking bureaucrats who had been appointed in the newly created office of the prime minister were from the president's own ethnic group. The new regime's barons appeared to be much bolder in staking claim to the state's resources than Ahidjo's supporters had been. Corruption and rent-seeking were always fundamental characteristics of the regime (Joseph 1978; Médard 1977; Gabriel 1999) but after 1984, they increased to a point at which the system became dysfunctional. When this political conjuncture was combined with a severe exogenous economic shock, the system finally started to crumble.

In the mid-1980s, the post-colonial state was confronted with a severe economic crisis (Van de Walle 1993; Konings 1996a). It posed a major threat to the economic base of the patrimonial state as well as to the system of prerogatives and privilege of the hegemonic alliance. A sharp downfall in commodity prices and a slide in the value of the American dollar against the CFA franc resulted in a 70 per cent deterioration in the country's terms of trade between 1986 and 1993. After some initial hesitation, the Biya government realised it had no alternative but to call upon the IMF and the World Bank to implement a Structural Adjustment Programme (SAP).

By 1990 widespread popular discontent with the regime in power and growing dissent within the hegemonic class could be observed. The majority of the population held the corrupt, authoritarian regime responsible for the serious economic crisis and draconian SAP measures, resulting in its loss of legitimacy. Some members of the elite, particularly those who had become dissatisfied with the regime because of its promotion of Beti domination, began to express general discontent and even tried to organise the urban masses into political parties. Taking advantage of widespread Anglophone resentment to their allegedly second-rate citizenship in the Francophone-dominated unitary state, John Fru Ndi, a book-dealer, launched the first opposition party, the Social Democratic Front (SDF), in Bamenda, the capital of the North West Province of Anglophone Cameroon in May 1990. By the end of the year, the regime had capitulated to demands for the introduction of a multi-party system and a certain degree of freedom of mass communication, association and the holding of public meetings and demonstrations (Takougang \& Krieger 1998).

Given the nature of the state-centred system of power, political liberalisation opened up the way for the articulation of deeply entrenched feelings of ethno- 
regional injustice. The vast majority of the newly created political parties had a clear ethno-regional base and at the time of the 1992 parliamentary and presidential elections, only four out of over 100 political parties claimed a national constituency. Still, the core support base and leadership of these four major parties were generally identified with particular regions. The party of the dominant class, the ruling CPDM party was perceived to be a Beti party while the National Union of Democracy and Progress (NUDP) was generally seen as a Fulbe party. Considered an Anglophone party backed by the Bamileke, the leadership of the SDF was dominated by people from the North West Province in Anglophone Cameroon. The stronghold of the Cameroon Democratic Union (CDU) was the Bamoun region (Eyoh 1998a and b; Mbembe 1993).

Even more significantly with the growing impasse of multi-party politics, the ethno-regional elites began to found associations to promote ethno-regional interests and achieve a larger ethno-regional share in national economic and political resources, including Essingang (Beti elite), La'akam (Bamileke elite), the South West Elite Association (SWELA), the Amicale des Elites du Nord (AMENORD), and the Dynamique Culturelle Kirdi (DCK) founded by the new elite of the 'silent majority' (the Kirdi) in the Far North (Nyamnjoh \& Rowlands 1998; Logo 1999). The Anglophone elite, too, created several associations to protest against the supposed subordinate position of the Anglophone minority in the Francophone-dominated unitary state and to lay claims to self-determination and autonomy.

\section{The construction of an Anglophone identity and competing identities}

Colonial boundaries have had an ambivalent impact on what has come to be known as the Anglophone problem. On the one hand, the boundary between Anglophone and Francophone Cameroon has laid the foundation for the construction of Anglophone and Francophone identities and the development of cleavages between the two elites. On the other hand, this boundary has failed to erase the existing ethnic relations between both territories altogether, enabling the Anglophone and Francophone elites to cement alliances if they were felt to be opportune. Moreover, although the population of the Anglophone territory came to share a common colonial legacy, ethno-regional boundaries continued to exist between the coastal forest area (the present South West Province) and the inland Grassfields area (North West Province) and cleavages developed within the Anglophone elite during decolonisation.

The colonial process of identity formation was strengthened by reunification and the post-colonial nation-state project. Determined to achieve and maintain a 
unitary state, successive Francophone-dominated post-colonial regimes have attempted to deconstruct Anglophone identity by encouraging existing divisions within the Anglophone elite and stimulating new ethno-regional identities that appear to transcend the Anglophone-Francophone divide.

\section{The construction of an Anglophone identity}

There is general agreement that the roots of the Anglophone problem can be traced back to the partitioning of the erstwhile German Kamerun Protectorate into British and French mandate and trust territories after the First World War (cf. Johnson 1970; Le Vine 1964 and 1971; Benjamin 1972). Separate colonial state formation and the development of territorial differences in languages and cultural legacies laid the spatial and historical foundation for the construction of Anglophone and Francophone identities. That one part of Anglophone Cameroon, which came to be called the Southern Cameroons, nevertheless voted for reunification with Francophone Cameroon rather than for integration into Nigeria in a United Nations-organised referendum on 11 February 1961 can not therefore simply be explained in terms of a long-awaited reunion of people separated by arbitrarily imposed colonial borders. Other factors seem to have been more important. First, having been administered as an integral part of Nigeria during the mandate and trust eras, the majority of the Anglophone population tended to perceive the integration option as a guarantee of continued domination of the Southern Cameroons by Nigerians. Second, ethno-regional power struggles between the Anglophone elite prevented them from finding a compromise concerning the political future of the Southern Cameroons and championing what the Anglophone population wanted, namely an independent Southern Cameroons state. And, last but not least, the anti-colonial Africa bloc at the United Nations, with the blessings of the United Kingdom, ruled out the possibility of sovereignty for the Southern Cameroons, claiming that this option was economically unviable and politically undesirable (since it would promote a further 'Balkanisation' of the continent).

An even more important factor in the construction of an Anglophone identity was the form of state that the Francophone elite imposed upon the Anglophone minority during the constitutional negotiations for a reunified Cameroon. The Anglophone delegation, led by Prime Minister John Ngu Foncha, had proposed a loose form of federation, which it considered a safe guarantee of equal partnership for both parties and of the preservation of the cultural heritage and identity of each. Contrary to Anglophone expectations, the Francophone delegation, headed by President Ahmadou Ahidjo, opted for a highly centralised form of federation that it saw merely as a transition phase in the creation of a unitary state. The most decisive factor, however, was the nation-state project after reunification. For the Anglophone population, nation-building was driven 
by the Francophone political elite's firm determination to dominate the Anglophone minority in the post-colonial state and to wipe out the cultural and institutional foundation of Anglophone identity (Eyoh 1998a: 262). Gradually, Anglophones felt they were being recolonised and marginalised in all spheres of public life and were becoming second-class citizens in their own country.

While there is a general tendency among Anglophones to blame the Francophone elite for the entire Anglophone problem, it cannot be denied that Anglophone political leaders bear an important share of the responsibility for the Anglophone predicament. Apparently, when they realised that their influence within the Federated State of West Cameroon (the former Southern Cameroons) was beginning to be whittled down, the federal arrangements no longer suited their designs. They started competing for Ahidjo's favours and aspiring to positions of power first within the single party and the federal government and eventually within the unitary state, thus blatantly neglecting the defence of West Cameroon's autonomy and interests (Kofele-Kale 1987).

The co-opting of the Anglophone elite into the hegemonic alliance and the autocratic nature of the Ahidjo regime largely explain why Anglophones failed to protest publicly against Francophone domination and recolonisation during the Ahidjo era. Immediately after succeeding Ahidjo, Paul Biya promised a New Deal to the Cameroonian people. Many Anglophones came to believe that Biya's reform programme would put an end to their allegedly subordinate position in the unitary state. They used the limited degree of political freedom during the first years of Biya's presidency to voice their long-standing grievances. Unfortunately, Anglophone optimism soon turned to despair as they began to realise that the much-trumpeted New Deal slogans were nothing but politicians paying lip-service to the problem and that the hegemonic and assimilative tendencies of the Francophone-dominated state continued unabated under Biya's rule. It was not until the political liberalisation process in the early 1990s that Anglophones openly began to organise in associations to defend their own interests.

\section{The construction of an ethnic identity transcending}

\section{the Anglophone-Francophone divide}

The newly created Anglophone associations often tend to stress the insurmountable gap between Anglophones and Francophones on the basis of their different colonial legacies and Francophone hegemonic and assimilative tendencies in the post-colonial state. While this is helpful in justifying their claims for either a return to the federal state or outright secession, it denies the continuous ethnic links between peoples in the so-called southwestern quadrant - the South West and North West Provinces of Anglophone Cameroon and the Littoral and West Provinces of Francophone Cameroon (Awasom 1998 and 2000). Most of the 
peoples in the coastal area of the Anglophone South West Province are, in terms of indigenous traditions and customs, closely related to the peoples in the coastal area of the Francophone Littoral Province, while most of those in the Anglophone part of the Grassfields (the North West Province) are closely related to peoples in the Francophone part of the Grassfields (the West Province) (Ardener 1967 and 1996).

The Anglo-French boundary was regarded as an unnecessary inconvenience by the frontier people in this area, restricting the free movement and trade of people belonging to the same ethnic group. It is, therefore, not surprising that the idea of reunification arose in this area. The quest for reunification was not shared with equal enthusiasm by other peoples in the former German Kamerun Protectorate, some of whom had more affinities with ethnic groups in neighbouring Nigeria than with the rest of Cameroon.

It was in the Francophone part of the southwestern quadrant, especially among the Bassa in the Littoral Province and the Bamileke in the West Province, that the UPC was formed in 1948 (Joseph 1977; Mbembe 1996). This radical nationalist party championed rapid independence and reunification. Its ideas of reunification influenced the nationalist leaders in the Anglophone part of the southwestern quadrant, with whom UPC leaders were in regular contact. The Anglophone nationalist leaders used the idea of reunification to obtain first a larger measure of autonomy within Nigeria and later separation from Nigeria. When the UPC was banned by the French in 1955, many of its leaders fled to Anglophone Cameroon where they opened local branches of the party. They considered the ethnically-related Anglophone region as offering refuge to their armed resistance against the pro-French government of Ahmadou Ahidjo until they were eventually expelled by the British. Awasom $(1998,2000)$ claims that John Ngu Foncha - the leader of the Kamerun National Democratic Party (KNDP), the pro-reunification party in the then Southern Cameroons - received substantial funds from Francophone politicians in the southwestern quadrant to support his campaign during the $1961 \mathrm{UN}$-organised plebiscite.

Ahidjo was shocked by the plebiscite results because of the close ethnic links between the Anglophone and Francophone elite in the southwestern area. He had expected the plebiscite to strengthen his position of power, which was still vulnerable at the time because of the persistent fierce opposition in the southern part of Francophone Cameroon to Fulbe-Muslim rule (Bayart 1979). His calculations were that the northern part of Anglophone Cameroon (the Northern Cameroons) dominated by the Fulbe Muslim elite, would vote for reunification with Francophone Cameroon where their ethnic brothers were in power, while the southern part of Anglophone Cameroon (the Southern Cameroons), whose elite shared a common colonial heritage with the southern Nigerian elite, would vote - with British support - for integration into Nigeria. 
The plebiscite results turned out to be the exact opposite of his prediction: the Northern Cameroons was lost to Nigeria while the Southern Cameroons opted to join Francophone Cameroon (cf. Le Vine 1964).

It was little wonder that Ahidjo started to panic. Instead of increased FulbeMuslim power in a reunified Cameroon, he now foresaw a possible coalition between the ethnically-related elite in the southwestern quadrant that was capable of destabilising his regime. To survive and consolidate his position, he was compelled to implement a number of strategies. First, he took full advantage of both France's continuous strong support of his regime and Britain's understandable withdrawal of support from its former trust territory that had refused to yield to British pressure to vote for integration into Nigeria rather than for reunification with Francophone Cameroon in the 1961 plebiscite. Capitalising on this situation during the constitutional talks for a reunified Cameroon, Ahidjo managed to insert extensive powers for the president of the federal republic into the constitution in spite of Anglophone proposals for a ceremonial presidency. Secondly, following reunification Ahidjo used his new powers to persuade Foncha to restrict the actions of its political parties to their region of origin: the Union Camerounaise (UC) of Ahidjo to Francophone Cameroon and the KNDP of Foncha to Anglophone Cameroon. Ahidjo was thus able to forestall any recruitment efforts by the KNDP in the Francophone part of the southwestern quadrant.

While Ahidjo succeeded in preventing any opposition alliance in the southwestern quadrant during his authoritarian regime, such an alignment did occur during political liberalisation when the SDF expanded its base from the North West Province to other provinces in the southwestern quadrant, especially the West Province where the Bamileke are the dominant ethnic group. By entering an alliance - often labelled the 'Anglo-Bami' alliance in common parlance with their Anglophone kinsmen, the Bamileke hoped to seize power from the Beti. In response to this alliance and the growing influence of Anglophone organisations, the Biya government tried to divide the newly founded alliance by promoting the so-called Grand Sawa Movement, a realignment of the ethnically-related coastal peoples in the Anglophone South West Province and Francophone Littoral Province on the basis of alleged North West-Bamileke (Grassfields) domination in their provinces.

\section{The construction of a South West and a North West identity}

Colonial boundaries have exacerbated rather than erased the existing ethnoregional cleavages within the Anglophone region between the coastal forest area (the present South West Province) and the inland savannah area (Grassfields), the North West Province. The South West elite has been inclined to perceive the colonial era as the starting-point of northwestern domination over 
their region in demographic, economic and political terms. Anglophone identity is therefore not homogeneous but marked by contradictions, contentions and contestations between the South West and North West elites.

Colonial rule brought together peoples in the coastal forest and Grassfields areas of Anglophone Cameroon who differed in socio-political organisation, culture and kinship structures. The highly centralised societies in the Grassfields were controlled by powerful, or even sacred, chiefs (Fons) and contrasted sharply with the segmented societies in the coastal forest areas where chieftaincy was a weak institution in most cases and often a colonial creation (Nkwi \& Warnier 1982; Geschiere 1993; Fisiy 1995; Konings 1999b). According to Eyoh (1998a: 270), such regional differences, in popular imagination, gave North Westerners an advantage over South Westerners in any struggle for economic or political power:

[There is] the representation of North Westerners as a people given to excessive deference to traditional authority and ethnic solidarity, and the adverse typing of South Westerners as a people with a weak sense of community and incapacity to unite behind common goals.

Colonial rule also set in motion massive labour migration from the more densely and less developed Grassfields to the coastal plantations created during German colonial rule. By 1950, the North West had become the most important supplier of labour to the southwestern plantations (Ardener et al. 1960; Konings 1993a). While initially most migrants returned to their region of origin after short spells of work on the estates, a growing number gradually decided to settle in the South West after retiring. 'Settlers' were soon joined by fellow members of their ethnic group who were eager to grow food or cash crops on the fertile volcanic soils in the South West or aspired to becoming artisans, traders or employees in local enterprises. In some coastal districts, like the Victoria District, the local population 'almost became overwhelmed by these strangers even before the Second World War' (Gwan 1975: 121). Indeed, settlers came to form the majority in local towns and villages.

Initially, settlers were welcomed by the local population and given land in usufruct, becoming more or less incorporated in the land-giving lineage. They were usually expected to provide a small token of appreciation for the landgiver. However as plantation agriculture expanded, it soon became evident that the local tenure system could not cope with the increasing flow of migrants that was leading to the development of a land market, land shortages and numerous land disputes (Ardener et al. 1960; Fisiy 1992). Local chiefs and elders regularly protested to the British administration about unscrupulous land grabbing by strangers in their areas of jurisdiction but they did not receive the 
support they expected. The British authorities acknowledged the existing land problems but did not introduce any structural changes. They did not want to disrupt the economic role of immigrants whose entrepreneurial spirit and hard work were said to compare favourably with the consumerist attitudes and laziness of the local population - a stereotype that has become internalised by South Westerners and North Westerners alike to explain northwestern domination over the South West.

Land was not the only reason for the development of antagonistic relations between the autochthonous population and the settlers. The local population also envied the settlers' success in agriculture, trade and other entrepreneurial activities and resented their frequent disrespect for local authority and customs, their seduction of local women and their alleged disinclination to invest in local development, preferring instead to transfer their accumulated capital to their region of origin (Ardener et al. 1960; Ardener 1962). It was generally believed that settlers were only interested in exploiting and dominating the local population, while continuing to remain loyal to their own ethnic group, as ultimately evidenced by their frequent desire either to return home at the end of their working life or to be buried on their ancestors' land. The simmering conflict between autochthons and strangers in southwestern communities continued to provide explosive material that could easily be manipulated and used by southwestern political entrepreneurs to strengthen the South West identity and to incite the local population against North Westerners (Konings 2001b).

The Anglophone elite initially demonstrated a large degree of unity during nationalist struggles after the Second World War but they became increasingly divided during the last phase of decolonisation. Different views on the political trajectory of the Southern Cameroons tended to be reinforced by personality differences between the major political leaders and ethno-regional differences within the Trust Territory: the South West-based Kamerun National Convention (KNC) party led by Dr Emmanuel Endeley championed integration into Nigeria, while the KNDP led by John Ngu Foncha favoured (eventual) reunification with Francophone Cameroon. The KNDP's victory in the 1959 elections was a political event with important consequences for South West-North West relations. While the South West elite had dominated the political scene in the Southern Cameroons until 1959, the KNDP's victory signified the start of North West hegemony in the Anglophone region, with Foncha becoming prime minister.

The results of the plebiscite reinforced the South West-North West divide. Pro-reunification votes were significantly higher in the North West than in the South West. The South West elite even alleged that the pro-reunification victory in the South West could be attributed to the large-scale settlement of North Western workers. Interregional elite rivalries reappeared when the Anglophones 
entered negotiations with the Francophone elite about the creation of a federal state. John Ngu Foncha headed the multi-party delegation of Anglophone Cameroon at the Foumban constitutional talks in June 1961. The delegation exhibited a preponderance of KNDP ministers who were obviously inclined to limit the role of the southwestern opposition parties at the deliberations (Ngoh 1996, 2001). The South West elite is still inclined to interpret the outcome of this conference, a highly centralised federation, and the post-colonial nationstate project as a self-interested betrayal of the autonomy of West Cameroon by the North West elite. They point out that northwestern politicians were in control of the Federated State of West Cameroon during the 1961-1972 period when multi-partyism and federalism were abolished. They add that North Westerners used their control over the Federated State to exclude the South West elite from administrative and bureaucratic posts and to promote North West business expansion (Rowlands 1993; Ngwane 1994). While these southwestern claims cannot be totally dismissed, it would be a historical error to exonerate the South West elite from blame for the Anglophone post-colonial predicament. The South West-North West divide was one of the most decisive factors preventing the Anglophone elite from forming a united front against Ahidjo's attempts to weaken the federal structure and undermine the autonomy and identity of West Cameroon. The speed with which the entire Anglophone political elite embraced the single-party concept and was incorporated into the hegemonic alliance is clear evidence of their lust for power and influence within the post-colonial nation-state project (Kofele-Kale 1987), even if equally a sign of their weakness in relation to their Francophone counterparts.

To reduce any danger of united Anglophone action, Ahidjo decided to formalise the ethno-regional boundaries between the coastal forest and Grassfields areas by dividing the erstwhile Federated State of West Cameroon into two provinces, the South West and North West Provinces in the aftermath of the establishment of the unitary state in 1972. This decision, masterfully informed by the internal contradictions within the Anglophone territory, would exacerbate these divisions that in future would be the Achilles' heel of most attempts at Anglophone identity and organisation.

Political liberalisation in the early 1990s fanned the rivalry between the South West and North West elite in their struggles for power at regional and national levels. The South West elite became alarmed by the rapid growth of both the North West-based SDF and several Anglophone associations. Since many members of the Anglophone associations were simultaneously SDF members, the South West elite was inclined to perceive these associations as auxiliary organisations of the SDF. Out of fear for renewed North West domination and in the face of their own inability to come up with a rival political party, they attempted to stimulate South West identity and organisa- 
tion, manifest in particular in the foundation of the South West Elite Association (SWELA) and the South West Chiefs' Conference (SWECC).

Given the intensification of the power struggles between the South West and North West elites during the political liberalisation process, the Biya government found it increasingly lucrative and politically expedient to tempt the South West elite away from Anglophone solidarity with strategic appointments and the idea that their real enemy was the unpatriotic, ungrateful and powermongering North West elite. Government divide-and-rule tactics culminated in the 1996 constitution, promising the southwestern autochthonous minorities state protection against the so-called dominant and exploitative North Westerners. Appeals to the state for protection were often accompanied by threats of ethnic cleansing and the removal of strangers (cf. Geschiere \& Nyamnjoh 1998 and 2000; Konings 2001b).

\section{Anglophones and the reconfiguration of state power}

The construction and mobilisation of ethno-regional identities during political liberalisation have given rise to widespread demands for constitutional change in Cameroon and brought about a fierce struggle between the government and ethno-regional political entrepreneurs concerning a reconfiguration of state power. The leaders of the newly created Anglophone organisations pose the greatest challenge to the continued existence of the highly centralised, unitary state by demanding first the reintroduction of a two-state (Anglophone/Francophone) federation and later outright secession. Both options have become a bone of contention between the ethno-regional elites within the Anglophone community itself and between the Anglophone and Francophone elite, though in some cases the Anglophone-Francophone divide appears to have been overcome.

The Anglophone political elite had already proposed a two-state federation in the decolonisation era with the aim of accommodating the different colonial legacies of the Anglophone and Francophone territories. At that time the concept of federalism appealed to the metropolitan powers as a means of conflict regulation in heterogeneous African states, particularly in countries like Ghana, Nigeria, Kenya, Uganda, Sudan and Eritrea-Ethiopia where the dominant ethno-regional groups tended to be geographically concentrated (Young 1998a). ${ }^{4}$ While the metropolitan powers usually took the initiative or

4 This comes close to the position of experts on federalism who maintain that if the territorial boundaries between the components of the federation match the boundaries between the relevant ethnic, religious and linguistic communities, i.e. if 
dominated constitutional negotiations concerning the introduction of a federal state, they had no authority and for the most part no inclination to maintain federal arrangements after the transfer of sovereignty. As in Cameroon, federal arrangements were undermined by the centralisation of power. The intolerance of federal arrangements were driven in large part by the desire to dominate state processes, which was seen as the principal means of promoting economic development and national integration. Moreover, the alluding fear in most countries where federalism had been proposed was that it was but a step to secession. Ghai (1998) argues persuasively that a refusal of regional autonomy is more likely to catalyse secessionist sentiments than federalism, as can be seen for example in the case of Sudan. Since its independence in 1956, Sudan has known only one decade of civil peace, from 1972 to 1983, when a semifederalist system was in place, giving some cultural security to the three southern provinces that do not share the Arabic-Islamic culture of the north (much less the fundamentalist version that has been dominant since 1989). The abolition of southern autonomy in 1983 led at once to a resumption of an unending civil war (Young 1998b: 11).

The apparent failure of the highly centralised unitary state to achieve economic development and national integration has given rise, during the second wave of democratisation, to renewed demands for the introduction of a federal state in several African countries including Cameroon (Basta \& Ibrahim 1999). Currently on the African continent only Ethiopia and Nigeria claim to operate federal polities and the legitimacy of their federal status has been questioned (Basta \& Ibrahim 1999; Bach 1999). The Ethiopian experiment is unique in Africa in the sense that the federating units are defined in ethnic terms and that the 1995 constitution (Article 39) allows for the secession of new states - a provision that could cause problems for the country's future territorial integrity (Abbink 1995 and 1997; Jembere 1999).

The reintroduction of a federal state is widely supported in the Anglophone community in Cameroon but the Anglophone elite appears to be divided on the number of states. The leaders of the newly created Anglophone organisations advocate a two-state federation based on the Anglophone-Francophone divide. The South West elite champions a ten-state federation based on the country's ten existing provinces, which they perceive as a safeguard against renewed northwestern domination in a two-state federation. The SDF supports a fourstate federation to appease its Francophone membership's persistent resistance to Anglophone demands for the return to a federal state. Interestingly, the renewed calls for the reintroduction of federalism seem to have transcended the

there is a federal society, then federalism can be an effective conflict-regulating device. See, for instance, McGeary \& O’Leary 1993: 33. 
Anglophone-Francophone divide. A small minority of the Francophone elite, most belonging to the opposition, also favours a federation but they, like the Anglophone elite, seem to differ on the number of states that should be established (Donfack 1998).

Faced with the Francophone-dominated state's refusal to enter into negotiations about a return to federalism, the leaders of the Anglophone organisations began to propagate secession. Like federalism, secession (from Nigeria) and the concomitant establishment of an independent Anglophone state was already an option in the Anglophone territory in the period preceding independence and reunification. Apparently, it was the preferred option in the region until eventually being dismissed by Britain and the United Nations. Subsequently, it was propagated only by small political parties like the Kamerun United Party (KUP), the Cameroons Commoners' Congress (CCC) and the Cameroons Indigenes Party (CIP), which boycotted the 1961 UN-organised plebiscite. Secessionist demands reemerged in Anglophone Cameroon in the mid-1980s when a prominent Anglophone chief and lawyer, Fon Gorji Dinka, demanded the immediate promulgation of an independent Anglophone state which he called the Republic of Ambazonia (Mukong 1990: 93-105).

Secession has been a rare option in post-colonial Africa and has been strongly opposed by the new independent states and the Organisation of African Unity (OAU) to safeguard territorial integrity. Secessionist attempts, as witnessed in Nigeria (Biafra), Congo/Zaire (Katanga) and Sudan are the exception. Secessionist demands have been on the increase since the early 1990s but appear mostly to revolve around the re-establishment of colonial partition-lines that were once erased or transformed into internal administrative boundaries. Eritrea's independence in 1993 after several decades of a national war of liberation is the only example of a formal reorganisation of the continent's political map. It may be interpreted as the re-establishment of the frontier that separated the former Italian colony from Ethiopia until it was invaded by Mussolini's troops in 1936. In the Horn of Africa, the Somali conflict has provoked a de facto return to the boundary that existed between the ex-British Somaliland and the Italian Somali until they merged in 1960. Further to the south, the United Republic of Tanzania - born out of the unification of Tanganyika (a former German colony) and Zanzibar (a former British protectorate) in 1964 - has been confronted with demands for the constitution of a separate government for the mainland. In Zambia, calls have been made for Barotseland to become a bastion of resistance against attempts by the Zambian government to act against the terms and spirit of the Barotseland Agreement signed in 1964 between Northern Rhodesia, Barotseland and Great Britain (Akashambatwa 2001). In West Africa, the Saharawi independence movement has been fighting for decades to secure international recognition of a boundary 
that has undisputed colonial origins. Elsewhere, agitation in Senegal's Casamance and in Anglophone Cameroon is rooted in the assertion of identity claims that draw some of their specificity from distinct colonial and linguistic legacies - Portuguese in the first case, British in the second (Bach 1999).

Strikingly, the Anglophone secessionist demand is not only strongly opposed by the Cameroonian government but also faces far more resistance than federalist demands in the Anglophone community itself. The South West elite and the SDF in particular continue to insist on the preservation of national unity and territorial integrity. It could even be argued that the re-emergence of the secessionist option has contributed to recent attempts to transcend the Anglophone-Francophone divide, as manifest in the creation and articulation of alliances such as the Grand West (the North West-Bamileke alliance) and Grand Sawa (the coastal South West-Littoral alliance).

In reaction to Anglophone demands for a return to a federal state or outright secession, the ruling regime continued to uphold the unitary state but eventually was willing to concede to a degree of decentralisation based on the ten existing provinces. Decentralisation is supported by the majority of the Francophone elite and the pro-CPDM Anglophone elite. Some members of the Francophone elite, however, seem to advocate a larger measure of decentralisation than the government is proposing (Olinga 1994; Donfack 1998). They claim that this would be a politically more acceptable and economically more effective method than federalism to accommodate the widespread dissatisfaction with the unequal regional distribution of power and income and the concomitant pursuit of regional autonomy in both the Anglophone and Francophone parts of the country. And finally, they argue that the Anglophone-Francophone divide has been exaggerated by some Anglophone power seekers, referring in particular to the close ethnic relations between Anglophones and Francophones in the southwestern quadrant.

\section{Organisation of the book and research methodology}

Having provided in this introductory chapter an overview of the most important themes that are to be explored, we can now proceed to explain how the book is organised and how we arrived at the research findings on which it is based.

Chapter 2 traces the historical trajectory of Anglophone Cameroon to reunification with Francophone Cameroon and the Francophone imposition of a highly centralised form of federation upon the Anglophone minority during constitutional talks proceeding reunification.

Chapter 3 outlines the various strategies by the Francophone-dominated state to undermine the autonomy and identity of Anglophone Cameroon during the 
federal and one-party unitary state (1961-1990) and the development of an Anglophone consciousness.

Chapter 4 describes the emergence of Anglophone organisations in the aftermath of political liberalisation in 1990 and their struggle first for a return to a federal state and later for secession.

Chapter 5 reviews the most important strategies employed by the Biya government during political liberalisation to deconstruct the Anglophone identity and uphold the unitary state.

Chapter 6 provides the reader with an insight into Anglophone and Francophone responses to the Anglophone movements' views and calls for autonomy, showing that both groups are by no means homogeneous and monolithic blocs.

Chapter 7 pays particular attention to two of the major confrontations between the government and the Anglophones, namely the struggle for the preservation of the Anglophone educational and economic legacy. During these struggles Anglophones have displayed a large measure of solidarity and forced the government to make some (temporary) concessions.

Chapter 8 summarises the book's major findings and provides some suggestions on how the present stalemate between the regime and the Anglophone movement could be broken and how the Anglophone problem could be solved.

The present study is based on our long-standing research in the Anglophone region of Cameroon. During fieldwork in 1998 and 2001 we consulted primary and secondary sources in libraries, archives, departments and ministerial offices. The rich historical material kept at the Buea National Archives was of particular use and interest. We also interviewed several leaders of various Anglophone organisations as well as a number of government officials and members of the Anglophone and Francophone communities who were either supporters, sympathisers or opponents of the Anglophone movement. Finally, the Scncforum on the Internet helped us to follow the current debate surrounding the Anglophone problem and to regularly update our research findings.

We recognise that the focus of our research has been mainly on the Anglophone elite. This is to a certain extent understandable since nationalism in Anglophone Cameroon, as in other parts of the Third World, has been first and foremost a project of the elites. Nevertheless, we are fully aware that grassroots considerations are necessary for a comprehensive account of the Anglophone problem in Cameroon. It would be interesting to know what impact the Anglophone struggle has had on the regional peasantry and we encourage future research on this subject to complement our own study. 


\section{Southern Cameroons on the road to reunification and federation}

The roots of the current Anglophone problem can be traced back to the First World War when the British and French occupied the erstwhile German Kamerun Protectorate and divided its territory into two parts. This partition gradually gave rise to the development of a different cultural heritage and identity in the British and French regions, a development that would create serious problems for any future attempts at reunification. It is therefore necessary to explain why, cultural and identity differences notwithstanding, the majority of the population in the southern part of the British Cameroon (which came to be called Southern Cameroons) voted for reunification with Francophone Cameroon in a UN-organised plebiscite in 1961.

An even more decisive factor in the current Anglophone problem was the form of state that the leaders of the Francophone majority more or less imposed upon the Anglophone minority following reunification. Anglophone leaders had proposed a loose form of federation that they considered a safe guarantee of the equal partnership of both parties and of the preservation of the cultural heritage and identity of each. Contrary to Anglophone expectations, however, the Francophone leaders opted for a highly centralised form of federation, which they saw as merely a transitory phase in the total integration of the Anglophone minority into a centralised unitary state. 
Eyoh (1998a) has rightly remarked that the narratives of pre- and postreunification experiences by the present Anglophone leaders have often been characterised by an impressive dose of historical amnesia - willed acts of selective remembrance of the past so that the Francophones would be seen fully responsible for the Anglophone problem. We want to show in this chapter that the divisions among the Anglophone political elite and their struggles for power are also responsible for reunification and the present Anglophone predicament.

This chapter is divided into three sections. The first presents a concise outline of the emergence of nationalism and the idea of reunification in the Southern Cameroons. The second section explains why the majority of the Southern Cameroonian population voted for reunification in the February 1961 United Nations plebiscite. And the final section describes the Francophone imposition of a highly centralised form of federation upon the Anglophone delegation during the July 1961 constitutional conference in Foumban.

\section{The emergence of nationalism and reunification ideas} in the Southern Cameroons

Several authors have narrated in considerable detail the complex historical trajectory of the Southern Cameroons toward reunification (cf. Le Vine 1964; Welch 1966; Johnson 1970; Ngoh 1990; Ebune 1992; Awasom 2001). Here we discuss only those elements that are important to the arguments in this book.

Southern Cameroons came into being after the First World War when the erstwhile German Kamerun Protectorate (1884-1916) was partitioned between the British and the French, first as 'mandates' under the League of Nations and later as 'trusts' under the United Nations (Rudin 1938; Gardinier 1963; Le Vine 1964; Joseph 1977). As a result of this partitioning, the British acquired two narrow non-contiguous regions in the western part of the country stretching from the Atlantic coast to Lake Chad and bordering Nigeria. The southern part and the focus of our study was christened Southern Cameroons, and the northern part was christened Northern Cameroons. ${ }^{1}$ Significantly, the British territory was much smaller than the French one, comprising only one fifth of the total area and population of the former German colony.

The partitioning of the territory into an English and a French sphere had some significant consequences for future political developments. For one thing, it had a lasting effect on the construction of Anglophone and Francophone

1 For the history of the Northern Cameroons, see, for instance, Le Vine 1964 and Welch 1966. Northern Cameroons voted in the 1961 plebiscite for integration into the Federation of Nigeria. 
identities in the territory. The populations of each sphere came to see themselves as distinct communities, defined by differences in language and inherited colonial traditions of education, law and public administration, and world view. Second, it could be argued that the very fact of partitioning the territory into two unequal parts sowed the seeds for the ultimate emergence in a reunified Cameroon of an Anglophone minority and a Francophone majority (Awasom 1998) that would affect the structure and distribution of power, resources and opportunities between the two communities in the postcolony. Third, the partitioning led to marked differences in the administration and level of development of the two parts. French Cameroon was incorporated into the French colonial empire as a distinct administrative unit, separate from neighbouring French Equatorial Africa. British Cameroon was instead administered as part of Nigeria. Whereas the Northern Cameroons was administered as an integral part of the Northern Region of Nigeria, the Southern Cameroons was initially governed as part of the Southern Provinces of Nigeria and later as an integral part of the Eastern Region of Nigeria. Differential administration also led to differential allocation of investment funds. Being administered as a separate unit, French Cameroon received substantial development funds from the mother country during the mandate and trust periods, resulting in a higher level of socio-economic development than in British Cameroon (Ndongko 1975). Being administered as a mere appendage of Nigeria, British Cameroon was starved of development funds by the administering authority and its economy remained centred around the plantations which had been established under German rule (Ardener et al. 1960; Epale 1975; Konings 1993a). There was not even a separate budget for the Southern Cameroons until 1954 when it achieved a quasi-regional status and a limited degree of self-government. Although no exact figures were kept about the territory's revenues and expenditures, the Southern Cameroons seems to have run at a deficit throughout the mandate and trust periods, and it required subsidies from the Nigerian budget. The question of the Southern Cameroons' economic viability outside the Nigerian structure became important as the separational and reunification movements grew stronger (Le Vine 1964: 201; Rubin 1971: 78; Mbuagbaw et al. 1987: 86-87).

Blatant neglect of regional development was only one consequence of the administration of Southern Cameroons as an integral part of Nigeria. Another, and maybe even more important one for future political developments, was the increasing migration of eastern Nigerians, especially Igbo and Ibibio, to the Southern Cameroons. Their dominant position in the Southern Cameroonian economy was deeply resented by the local population. The 'Igbo scare' was going to be exploited by regional politicians during the nationalist struggles after the Second World War (Kleis 1980; Amazee 1990). It is beyond any doubt 
that both the Southern Cameroonian peripheral position as a "colony of a colony' (Nigeria) and the Nigerian domination of the Southern Cameroonian economy contributed to the development of a Cameroonian identity and nationalism among the local population.

The nationalist movement began with the creation of several associations and pressure groups formed by the Southern Cameroonian elite, the first of them being established in Lagos in 1939. These organisations, like the Cameroons Youth League (CYL) and the Cameroons National Federation (CNF) (Chiabi 1982; Ebune 1992; Ngoh 2001), began to attack the subordinate position of the Southern Cameroons in the British-Nigerian colonial system. Their most important claims were initially a larger representation of the Southern Cameroonian elite in the Nigerian administration and later regional autonomy. Such claims received special encouragement after the Second World War when the Southern Cameroons became a trust territory under the supervision of the United Nations. The United Nations Charter stipulated that trusteeship was intended to promote the political advancement of the trust territories towards self-government and independence. The United Nations Trusteeship Council had the right to undertake investigations and to secure reports to determine if such advancement was occurring. The Council sent missions to the Southern Cameroons in 1949, 1952, 1955 and 1958 to receive petitions and interview representatives of Southern Cameroonian political groups. Such missions were important stimuli to the formation of local groups and the articulation of their demands (DeLancey 1989: 36).

Interestingly, from the late 1940s onwards the question of reunification cropped up in the programmes of the various Southern Cameroonian pressure groups and newly created parties, raising the possibility of an alternative political option for the Southern Cameroons to escape from its subordinate position in the British-Nigerian colonial system and from Igbo domination. Several factors underpinned their reunification campaign. There was the emergence of the 'Kamerun Idea' among some members of the Southern Cameroonian elite - the belief that the period of German rule had created a Cameroon identity or nation (Welch 1966: 158-88; Johnson 1970: 42). Some authors have pointed out that this idea hardly corresponded with reality since German colonial rule had been too short to create a Cameroon identity among the multiplicity of ethnic groups in its territory (Ardener 1967; Le Vine 1964; Chem-Langhëë \& Njeuma 1980). Kofele-Kale (1980), however, argued that it was not the reality of the German experience but rather the memories (factual or otherwise) or myths that inspired the Southern Cameroonian elite to start advocating reunification. To strengthen their arguments, the Southern Cameroonian elite often referred to the close relationships that existed between ethnic groups on both sides of the British-French border. In some cases, this 
border had even divided the same ethnic groups in the so-called southwestern quadrant (see Chapter 1).

The idea of reunification was particularly promoted by settled migrant communities from French Cameroon in the Southern Cameroons. These migrants fell into two categories. The first was composed of traders, mostly Bamileke and Bamum, who were involved in a dynamic commercial traffic across the frontier. A crucial aspect of this was the existence of relatives, cultural and other support systems on both sides of the frontier. They saw reunification principally as a means of lifting the customs restrictions between British and French Cameroons. The second category consisted of a Francophone elite residing in the Southern Cameroonian urban centres. They considered reunification principally as a way to eradicate discrimination by the British Administering Authority and remove their second-class citizenship in the Southern Cameroons. One of their best-known leaders, Mr R.J.K. Dibongue, was instrumental in forming the French Cameroons Welfare Union (FCWU) in 1948 and the Kamerun United National Congress (KUNC) in 1951 to advance the political and economic position of Francophone Cameroonians and the idea of reunification (Amazee 1994; Njeuma 1995; Awasom 2000).

Another factor that encouraged the idea of reunification was the formation of a radical nationalist party in French Cameroon in 1948, the Union des Populations du Cameroun (UPC) (Joseph 1977; Mbembe 1996). This party stood for immediate independence and reunification. Soon after its formation, the UPC sought contact with the ethnically-related Southern Cameroonian leaders and tried to influence their political awareness (Takougang 1996), taking advantage of the refuge offered to some of its persecuted members to test the waters and sow the seeds of reunification in the region.

It must, however, be admitted that for a long time the idea of reunification remained a vague ideal towards which few steps were being taken. None of the Southern Cameroonian political leaders ever described or outlined the form which reunification should take. Moreover, contrary to the UPC, most were inclined to look upon reunification as an evolutionary trajectory. They appeared, in fact, to be more concerned in the meantime with internal issues, particularly the improvement of the Southern Cameroonian position within the Nigerian Federation. They often brought up the issue of reunification in their petitions to the United Nations missions as a way of gaining 'home rule' within Nigeria (Welch 1966: 150; Ngoh 1996: 187). For instance, one of the leading Southern Cameroonian nationalists, Dr E.M.L. Endeley, used the issue of reunification mainly as an instrument to embarrass the colonial administration and to create support for the push towards an autonomous province within Nigeria (Le Vine 1964: 203). In response to Southern Cameroonian pressures, the British authorities gradually increased Southern Cameroonian representa- 
tion in the Nigerian administration after the Second World War. Following successive constitutional changes, they granted Southern Cameroons a quasiregional status in 1954 and a limited degree of self-government, and in 1958 full regional status within the Federation of Nigeria (Ngoh 1990).

From the mid-1950s onwards, nationalist leaders in the Southern Cameroons became increasingly divided. Different points of view on the political trajectory of the Southern Cameroons tended to be reinforced by personality differences between the major political leaders and ethno-regional differences within the territory. The key players were Dr Emmanuel Endeley and John Ngu Foncha, both early leaders in the Southern Cameroons national struggles.

Endeley, a medical doctor by training, was from the Bakweri, an ethnic group in the coastal forest area of the Southern Cameroons (the present South West Province). He was the leader of the then-ruling South West-based Kamerun National Convention (KNC) party. Following constitutional changes Endeley became the Leader of Government Business in 1954 and the first Prime Minister of the Southern Cameroons in 1958. He had moved from an anti-Nigeria and pro-reunification stand towards a more positive view of Nigeria when Southern Cameroons became a quasi-region within Nigeria in 1954. His new position was even strengthened when Southern Cameroons achieved full regional status in 1958. From his perspective, regional status seemed an adequate answer to the problems of Nigerian domination, the lack of Southern Cameroonian participation in the Nigerian political system, and economic stagnation. With regional status, Southern Cameroonians could rule themselves, maintain their ties to the British inheritance, and avoid the violence and chaos of the civil war in French Cameroon that had been going on since 1955 when the UPC was banned by the French authorities and subsequently engaged in an armed rebellion (Joseph 1977). Being married to a woman from Yorubaland in Nigeria might have influenced his positive attitude and enthusiasm towards Nigeria (Mbile 2000). Endeley's increasing championship of integration of the Southern Cameroons into Nigeria received the overt blessings of the British authorities who intended to integrate the Southern Cameroons into Nigeria in the same way as British Togoland, another United Nations trust territory under the United Kingdom, had been incorporated into Ghana in 1956 through a UN-organised plebiscite (Brown 1980). Being a Bakweri, he was most likely to attract political support in the South West. Nevertheless, it would be a mistake to consider his party as an exclusively ethno-regional party. Endeley also enjoyed some support in the inland Grassfield part of the Southern Cameroons (the present North West Province). While he was often admired for his high educational and political achievements, all his life histories equally reveal that his personality often estranged potential voters in the South West and North West alike. 
He was widely seen as extremely arrogant. He frequently boasted of being the most highly educated citizen in the Southern Cameroons and he regarded his political contemporaries as mere intellectual minions, and villagers as outright natives. He spoke a sophisticated English and even in the heat of an election campaign he would refuse to speak to the northwestern chiefs in the language they understood (pidgin English) with the excuse 'I am sorry about speaking my "big" English ... but I cannot speak any other way'. He was also a Bakweri chauvinist. Endeley's ethnic loyalties sometimes combined with his own personal pride to generate hostility among other ethnic groups. On one occasion he is reported to have bragged to an audience in the Mamfe District of the South West that its peoples would never produce someone of the standing of the leaders produced by the Bakweri (referring, no doubt, to himself). This hurt, and the Mamfe electorate later remembered his words. In addition, Endeley's attitudes and behaviour tended to alienate the chiefs, particularly those in the North West. The northwestern population was largely controlled by powerful, or even sacred, chiefs (or Fons as they are called throughout the North West) whose authority was highly respected by their subjects, including the newly created elite. The position of chiefs in the highly centralised states of the North West contrasted sharply in this respect with that of their colleagues in the segmentary societies of the South West where chieftaincy was a weak institution in most cases and often a colonial creation (Geschiere 1993; Fisiy 1995; Konings 1999b). Firm support from chieftaincy in the densely populated North West could be crucial in elections. Though a Bakweri prince (some even said the heir-apparent), Endeley made many mistakes in dealing with the symbols and spokesmen of tradition in the territory. He would offend the fons by shaking their hands, sitting at their side on stools reserved for their fellow fons or by addressing them by the wrong title or at the wrong times. ${ }^{2}$ Endeley's attitude towards chieftaincy was nevertheless complicated. He was by no means unaware of the chiefs' prestige since he was himself the son of the most important Bakweri chief. But he was also a highly educated person living in an era when power was obviously shifting from the traditional to the modern elite. He acknowledged he could not do without the chiefs' support completely and was therefore not opposed to their repeated demands for a House of Chiefs (Johnson 1970: 162-63; Welch 1966: 190-94; Wache 1991: 6-7; Konings 1999b).

2 Endeley has been reported to have treated one of the most important northwestern chiefs, Fon Galega II of Bali, with levity. One version holds that on a trip to London, after alighting from the plane, he peremptorily asked the fon to carry his bag. N.N. Mbile, another illustrious South Western politician who was on the same trip, has recently strongly denied this story, claiming that it was an opposition plot to win the support of the Bali people. See Mbile 2000: 105-10. 
Endeley's opponent, John Ngu Foncha, was a teacher by profession and hailed from the North West. ${ }^{3}$ Foncha had been a leading figure in Endeley's KNC until 1955 when he broke away to form his own party, the North Westbased Kamerun National Democratic Party (KNDP). Foncha and his supporters blamed Endeley for no longer adhering to the original $\mathrm{KNC}$ programme of evolutionary reunification of the two Cameroons and for his new pro-Nigeria stance. While Foncha's political views on the future of the Southern Cameroons were not always consistent, he seems to have mostly crusaded for secession from Nigeria and (eventual) reunification with French Cameroon. Political dissension, however, was not the only reason for Foncha's break with Endeley's party. He thought that a North West-based party was more likely to represent and defend northwestern interests than a South West-based party. Ethnically different from the South West peoples, North Westerners had also been left at a socio-economic disadvantage during the colonial period through the more extensive development of education, infrastructural provisions, agroindustrial and other enterprises in the South West. Furthermore, leaders of the South West dominated those from the North West in political affairs. According to Ebune (1992: 152-53), Foncha, as a staunch Catholic, was also disturbed that all the four KNC members of the first executive council established in 1954 were Protestants. He was subsequently encouraged by the Catholic Church to form a more Catholic-oriented party.

Unlike the highly educated, arrogant and Protestant Endeley, Foncha was an uncomplicated, devout Catholic headmaster who perhaps felt more secure speaking pidgin English or an indigenous language than standard English. Foncha was basically a grassroots politician who would walk all day to reach a remote village of voters (Soh 1999). He presented himself as an African who was proud of wearing a sumptuous traditional boubou rather than a suit and tie, and preferred eating African food to European food. Folklore has it that on one visit to London, Foncha carted along achu (a Grassfield delicacy), which he publicly ate with relish to show his attachment to things African. Above all, Foncha displayed great respect for tradition, both its symbols and custodians. His attitude to them was scrupulously deferential if not reverent, and earned him the recognition and ear of the fons. Foncha and other KNDP leaders like Augustine Ngom Jua made good use of the support of the fons during the 1959 elections (Welch 1966: 190-94; Johnson 1970: 162-63; Wache 1991: 6-7; Konings 1999b).

With the approaching independence of Nigeria and French Cameroon in 1960, the 1959 elections became a relentless struggle for hegemony between the dominant parties and leaders in the Southern Cameroons. It was generally

3 For Foncha's biography, see Soh 1999. 
understood beforehand that the victor in these elections would be given a mandate to negotiate the political future of the territory. One of the dominant parties, Endeley's KNC had in the meantime formed an alliance with another South West-based party, N.N. Mbile's Kamerun People's Party (KPP). Pursuing the same objective - the integration of the Southern Cameroons into Nigeria both parties later merged to form a new party, the Cameroon People's National Congress (CPNC). The obvious aim of their alliance and later merger was to create a united front against the KNDP, seen and treated as a Grassfields threat to South West interests and prominence.

During the election campaign, the KNDP used various strategies to defeat the CPNC. The first was the attempt to capitalise on the widespread 'Igbo scare', an issue that the CPNC apparently underestimated. The KNDP leaders alleged that a vote for the CPNC would mean the integration of the Southern Cameroons into Nigeria and the continuation of Igbo domination. A vote for the KNDP would instead imply the separation of the Southern Cameroons from Nigeria and the end of Igbo domination. Remarkably, while singling out the issue of separation from Nigeria as a major campaign issue, the KNDP tended to underplay its championship of an eventual reunification with French Cameroon. This was a deliberate strategy as the party had become painfully aware during its campaign that reunification was not popular among the electorate who appeared to be not only afraid of the repercussions of the violent civil war going on in French Cameroon, but also unfamiliar with, and even distrustful of, the French colonial heritage. A second strategy was the attempt to present itself as a regional party, especially when campaigning in the North West. Since most of its main leaders hailed from the North West, the KNDP could easily project itself as a party that was more likely to defend North Western interests than the South West-based CPNC. Several political blunders by the Endeley government tended to confirm the party's claim. One such mistake, which seriously undermined Endeley's support in the North West, was the enforcement of contour ploughing. This threat to long-established agricultural practices infuriated northwestern women, the traditional producers of food in the area (Konings 1995a; Goheen 1996). One of the KNDP leaders, Augustine Ngom Jua, exploited female discontent in his home area by inciting the Kom traditional women's organisation called Anlu to stage various actions against Endeley's government and party (Nkwi 1985; Shanklin 1990). A third strategy was to lobby influential chiefs and chiefs' conferences, particularly in the North West, well aware that the fons still exercised a large measure of control over the local population's voting behaviour. The wide-ranging influence of northwestern chieftaincy on domestic politics was clearly recognised by one of the principal CPNC leaders, Mr N.N. Mbile, in September 
1959 when he commented as follows on the role of chiefly authority during a session of the United Nations Fourth Committee:

Much of the present struggle was really between the grassland tribes in Bamenda and the people of the southern coastal forest belt. His own opinion was that even a plebiscite would not serve to make clear what the real wishes of the people were, for they were still loyal to their tribal leadership, especially in the Bamenda Grassfields, and might well vote against that own interest if such was the wish of their chiefs. ${ }^{4}$

By employing such strategies, the KNDP was able to win the 1959 elections. On the one hand, its victory was a political event with important consequences for South West-North West relations. While the South West elite had dominated the political scene in the Southern Cameroons up to the 1959 elections, the KNDP's victory signified the start of North West hegemony in the territory. Henceforth, the North West elite began to play a dominant political and economic role at regional and national levels. In pre-empting for itself the choicest jobs and lands in the South West, it provoked strong resentment among South Westerners (Kofele-Kale 1981; Ngwane 1994). South West sentiments have been intensified by the gradual success of the entrepreneurial North Westerners in dominating most sectors of the South West economy, in particular trade, transport and housing (Rowlands 1993). On the other hand, the KNDP's victory was so narrow, winning 14 of the 26 seats, that it did not provide Foncha with a clear mandate to start negotiating the political future of the Southern Cameroons. The United Nations visiting mission, which left the territory shortly before the elections, recommended therefore consulting the population in a plebiscite unless general agreement could be reached among all the major political parties regarding the constitutional future of the territory.

\section{The 1961 United Nations plebiscite}

Less than a month after the January 1959 elections, Foncha and Endeley flew to New York to attend the resumed thirteenth session of the United Nations General Assembly, called solely to debate the future of the Cameroons. During the debate both leaders continued to defend their different views. The General Assembly finally agreed that a plebiscite should be held to decide the issue. The two party leaders then became divided on the questions that should be presented to the voters in the plebiscite.

Foncha proposed a choice between separation from the Federation of Nigeria and association with it. He stressed that the KNDP first wanted

4 UNGA A/C.4 SR 885 of 24 September 1959. 
separation from Nigeria before starting any negotiations for an eventual reunification with French Cameroon. He even suggested the trusteeship period be extended for a few years to offer the Southern Cameroons the opportunity to develop politically, economically and culturally, which would enhance its bargaining position with French Cameroon. Endeley, in turn, proposed a choice between reunification with an independent French Cameroon and association with an independent Nigeria. In his statement, he noted that during the elections campaign the issue of reunification had been pushed into the background and the question of domination by the Eastern Region of Nigeria raised instead. He stressed that secession could not be an end in itself but only a first step. Hence, voters were to choose between association with an independent Nigeria and reunification with an independent French Cameroon.

The two men refused to budge from their positions and a compromise could not be reached. The General Assembly then recommended that the wording of the plebiscite questions be decided at the fourteenth session after the Southern Cameroonian leaders had considered the matter further.

Neither Foncha nor Endeley would yield during the summer despite the General Assembly's resolution. Upon the urging of the Governor-General of Nigeria, a summit conference of chiefs and political leaders was held in Mamfe in August 1959 to discuss the matter but no agreement could be reached. Interestingly, one of the newly created South West parties, the Kamerun United Party (KUP), even proposed another option: separation from Nigeria and the establishment of an independent Southern Cameroons state. Its leader, Mr P.M. Kale (1967), questioned the necessity of a plebiscite, arguing that the terms of the Trusteeship Agreement guaranteed the Cameroons 'the right to the enjoyment of self-government or independence ... even if Nigeria had not set the ball rolling' (Ngoh 1990: 173). The chiefs supported his position of secession without reunification. In a colourful and memorable statement, their spokesman, Fon Achirimbi II of Bafut, metaphorically presented French Cameroon as 'being on fire' because of the civil war that was raging there, and giant Nigeria as the 'water' in which the Southern Cameroons would easily drown should it chose to go there. He reminded the delegates that 'we rejected Dr Endeley because he wanted to take us to Nigeria; if Mr Foncha tries to take us to the French Cameroons we shall also run away from him' (Awasom 2000: 108-9). What clearly emerged from the conference was that reunification was not a popular theme, the vast majority advocating either integration into Nigeria or secession from Nigeria (Foncha's KNDP supported secession and ultimate reunification, while Kale's KUP supported secession and complete independence).

Unable to resolve their differences at the Mamfe conference, Foncha and Endeley returned to the fourteenth general assembly of the United Nations in 
September 1959. During the debates it became manifest that the General Assembly, and in particular the African and anti-colonial delegations, opposed secession. Foncha's option of secession and continuing trusteeship was rejected because it would imply the prolongation of colonialism. Kale's option of secession and complete independence for the Southern Cameroons - an option that was even supported by both Endeley and Foncha for a brief moment during the heated discussions - was rejected for two main reasons. First, the African delegates were fearful of a further Balkanisation of Africa by granting a separate independence for the tiny Southern Cameroons. And second, the British had informed the United Nations that the Southern Cameroons was not sufficiently economically viable to constitute an independent state. The British source of information was the Phillipson Report commissioned by the Foncha government in 1959 to investigate the financial, economic and administrative situation in the Southern Cameroons (Phillipson 1959). The findings of this report, however, could be disputed for an economic survey by Dr K.E. Berill, held in the same year, came to a different conclusion (Berill 1960). Hesitant about making any large investments in a region that was supposedly unattractive economically, the British were also opposed to extended trusteeship. The British Secretary of State for the Colonies once warned the Southern Cameroonian leaders that the golden key to the Bank of England would not be handed over to the Southern Cameroons in the case of an extended trusteeship period.

Having ruled out both continuing trusteeship and an independent Southern Cameroons state, the United Nations then limited the choice of questions to be asked in the plebiscite to: Do you want to achieve independence by joining Nigeria or by reuniting with the Republic of Cameroon (the new name of former French Cameroon after independence on 1 January 1960)? It is evident that the two alternatives closely reflected Endeley's previous proposals. Foncha was eventually persuaded to accept the two options if Endeley agreed to compromise and accept a delay in the plebiscite with a view to giving the parties more time to educate the Southern Cameroonian population on the implications of the two alternatives ${ }^{5}$. The compromise between the two leaders was embedded in General Assembly Resolution 1352 (XIV) of 16 October 1959, which requested that the plebiscite be held no later than March 1961. Three smaller Southern Cameroonian parties - the Kamerun United Party (KUP) led by Paul Kale, the Cameroons Commoners' Congress (CCC) led by Chief Stephen Nyenti, and the Cameroons Indigenes Party (CIP) led by Jesco Manga Williams - immediately contested the outcome, insisting on the

5 Foncha also hoped that the continuing civil war in Francophone Cameroon, which might constitute an obstacle for the electorate to vote for reunification during the plebiscite, would come to an end during this period of delay. 
inclusion of an independent Southern Cameroons state as a third option in the plebiscite. They sent several petitions to the United Nations threatening to boycott the plebiscite if their wish was not honoured. Their protest actions, however, did not bear fruit (Ngoh 1990: 179-80).

Foncha was embarrassed. The decision by the United Nations forced him to come to grips with the issue of reunification, a matter to which he had not given serious thought and that, as he had painfully realised, was likely to enjoy little support among the vast majority of the Southern Cameroonian population. Most KNDP members felt betrayed because Foncha had made promises before his departure for New York that he would advocate an extension of the trusteeship period for another two or three years (Ebune 1992: 180). Apparently, some party leaders were even considering replacing Foncha as prime minister. His deputy, Mr Augustine Ngom Jua, in particular, challenged his leadership (Johnson 1970: 147).

To overcome the widespread opposition to his new stand, Foncha attempted to transform the concept of reunification into one of federation (Njeuma 1995: 33). From his experience with Nigeria, Foncha was familiar with federal institutions and the machinery of federal government. And, maybe even more importantly, he had witnessed at firsthand a trend in Nigeria towards a 'looser' form of federalism, with a large measure of regional autonomy (Ezera 1964; Walker 1992). Foncha then began to propagate the idea of a similar form of federation, almost a confederation, which he perceived as a safe guarantee for a large measure of autonomy for the Southern Cameroons after reunification, equal partnership and preservation of the cultural heritage of each partner. With such a federalist conception, he tried to regain the confidence of his party members and to assure the Southern Cameroonian population that no fundamental change would occur after reunification. Foncha's major problem, however, was that he would have to enter into concrete negotiations with French Cameroon - a territory with a fundamentally different political culture and constitutional set-up - about the constitutional modalities of a future union should the Southern Cameroons vote for reunification in the plebiscite.

Ahmadou Ahidjo, who was prime minister of French Cameroon for about two years before becoming president of the independent Republic of Cameroon on 1 January 1960 (Bayart 1979), appears to have been lukewarm about the ideas of reunification and federation (Awasom 2000, 2001). In his inaugural speech in the French Cameroon Legislative Assembly on 18 February 1958, he committed himself to the reunification and independence of the two Cameroons. He indicated that if reunification was the wish of British Cameroon, he could not object to it. But he hastened to warn that under no circumstances would reunification delay the independence of French Cameroon, implying that reunification was not his priority. Ahidjo's 
endorsement of reunification and independence appears to have been largely a tactical strategy to appropriate the cherished slogans of the UPC rebels and deprive them of their ideological platform and relevance. Moreover, he had ambivalent feelings about the political consequences of reunification. On the one hand, he was apprehensive that in any such reunion the Southern Cameroons would join forces with his political foes in the southern part of French Cameroon and bring about his own political downfall. His anxiety arose from his perception of the Southern Cameroons as being all too similar ethnically and politically to the rebellious elements in the southwestern part of French Cameroon. Bands of UPC maquisards were already using the frontier zones of the Southern Cameroons as a safe haven to which to escape after carrying out attacks in French Cameroon. On the other hand, however, he showed a keen interest in reunion with British Northern Cameroons, which was geographically, religiously, ethnically and culturally closer to the northern part of French Cameroon, his home region. Reunion with British Northern Cameroons could greatly enhance his political fortunes: it would widen his ethnic and political base significantly.

Given his lukewarm and somewhat ambivalent feelings about reunification, it is understandable that Ahidjo remained sceptical and evasive with regard to Foncha's repeated invitations to enter into negotiations on the establishment of a federal state after an eventual reunification. On the rare occasions when he openly expressed his views on the matter, he intimated that reunification would involve a gradual process and that it would not imply an annexation of the Southern Cameroons by the Republic of Cameroon. He also assured Southern Cameroonians that discussions about the issue of reunification would take place in an atmosphere of complete freedom and equality between representatives of the Republic of Cameroon and the Trust Territory of Southern Cameroons. When he finally entered into negotiations with Foncha, it soon became manifest that he strongly opposed Foncha's proposal of a loose federation as being incompatible with the highly centralised constitution he advocated himself. Ahidjo clearly lacked Foncha's experience with the intricate workings of federalism. His thoughts had been shaped by the centralised and assimilative administrative structure characteristic of the French colonies. He had also been engaged in the drafting of a constitution for the independent Republic of Cameroon that laid the foundation for a highly centralised state and a strong executive power largely based on the constitution of the Fifth Republic (Le Vine 1964). The March 1960 constitution had been adopted in an extremely difficult political climate and was intended to help Ahidjo consolidate his position in the newly independent Republic of Cameroon (Bayart 1979; Awasom 2001). Foncha's proposals, being tantamount to the decentralisation and deconcentration of power and the adoption of a completely new political 
framework, would have had the nefarious effect of weakening Ahidjo's newly achieved power base and erasing Francophone political culture. Moreover, the paradigm of modernisation, which dominated the literature on political and economic development in the 1950s and 1960s, reinforced Ahidjo's views on the importance of a strong unitary state for nation-building and economic reconstruction in Africa (Cameroon National Union 1968).

Foncha and Endeley had been requested by the United Nations to define publicly, prior to the plebiscite, the form of union they envisaged with Francophone Cameroon and Nigeria respectively. Less than seven months before the plebiscite, during Ahidjo's first official visit to the Southern Cameroons on 15 July 1960, Foncha had openly to confess that no form of union with Francophone Cameroon had yet been worked out. Time was running out for Foncha as the plebiscite campaign was supposed to be launched on 1 October 1960 when Nigeria acceded to independence. The position of Endeley's CPNC on the issue of integration with Nigeria was well known. In the eventuality of the Southern Cameroons opting to join Nigeria, the territory would become a self-governing region, equal in all respects to the other regions in the Nigerian Federation. Ridiculed and castigated by Endeley for gambling with the destiny of the Southern Cameroonian people, and pressured by the British to produce a document clearly spelling out the envisaged form of union with Francophone Cameroon, the KNDP panicked. Foncha was requested to bring more pressure to bear upon Ahidjo and draft a document at all costs for the purpose of the plebiscite.

Eventually, on 14 October 1960, Ahidjo and Foncha issued a joint communique announcing that they had agreed on a union of both Cameroons on a federal basis should the Southern Cameroons vote for reunification in the plebiscite. The document, however, conspicuously failed to define the exact division of power between the federal government and the component units of the federation. Some vague phrases like 'first stage' and 'second stage' were used without the slightest attempt to define them. The constitutional terms of the Southern Cameroons joining the Republic of Cameroon were laid down in barely two and a quarter pages of The Gazette in contrast to those of the Southern Cameroons joining Nigeria that covered six pages. Apparently both parties failed to make any further progress due to their diametrically opposed political traditions and interests. Ahidjo strongly dismissed Foncha's proposal of a loose federation. Given the particular situation of uniting two territories with different colonial legacies, he appeared nevertheless prepared to concede to a highly centralised form of federation, almost a non-federation, which he saw as a necessary transitory phase to his ultimate goal, namely the full integration of the two component entities into a strong, unitary state. 
Dissatisfied with the outcome of these protracted negotiations, Foncha resorted to two different strategies. On the one hand, he continued to tell the Southern Cameroonian population that a loose federation would be formed after reunification (Ngoh 1990: 191-94). He was able to do so because any report of his negotiations tended to be vague. On the other hand, he appeared to be ready to simply abandon the idea of reunification and its complex constitutional implications for some time. Like Endeley, he was under severe pressure from the majority of the Southern Cameroonian elite to continue fighting for the establishment of an independent Southern Cameroons state. When the CPNC proposed to the KNDP that the two parties request that the United Nations cancel the upcoming plebiscite and grant the Southern Cameroons independence, Foncha agreed. A conference was organised in London in November 1960 to obtain the approval of the British government.

The British authorities initially showed some sympathy for the predicament of Southern Cameroonians but eventually it rejected the proposal on the grounds that 'the United Nations in adopting the two alternatives of joining Nigeria or the Cameroon Republic, clearly ruled out a period of continuing trusteeship or separate independence for the Southern Cameroons' (Ngoh 1990: 195-98). As a result of the failure of this conference, Foncha was obliged to restart his negotiations with Ahidjo. The only noteworthy outcome of this conference was the confusion it created in the minds of the Southern Cameroonian voters due to insufficient information or even misinformation. Although the request had been rejected, some Southern Cameroonians started to believe that the second alternative had been altered into 'secession without reunification'. Others thought that the Southern Cameroons had been granted a probationary period of reunification with the Republic of Cameroon. If Southern Cameroonians did not find reunification rewarding at the end of this period, they could still pull out of the union and form a separate independent state. The KNDP politicians, realising that the confusion was to their advantage, remained unmoved, while the CPNC failed to clarify to the electorate the true outcome of the conference. As a result, a considerable number of Southern Cameroonians seemed to have voted during the plebiscite for the second alternative thinking it implied 'secession without reunification' or a 'probationary period of reunification' (Ngoh 1990: 197-98; Chem-Langhëë 1976, 1997).

The United Nations set the date of the plebiscite for 11 February 1961. Under United Nations auspices a public-education campaign was started to explain the constitutional consequences of the Southern Cameroons joining either Nigeria or the Republic of Cameroon. One hundred thousand copies of an official brochure, The Two Alternatives (Federation of Nigeria 1961), were printed and distributed as part of this campaign. It is, however, most unlikely 
that in a society with a low literacy rate such as the Southern Cameroons, complex written explanations of constitutional guarantees had any significant impact. By all accounts it is evident that the various parties appeared to be more interested in the number of votes gained than in educating the people about the constitutional consequences of their choice.

Both the KNDP and the CPNC used similar tactics to those employed during the 1959 elections to win votes. The KNDP tried to attract voters by stressing again those issues that most Southern Cameroonians resented such as Igbo domination, the British-Nigerian neglect of the territory and the possible swamping of the tiny Southern Cameroonian population within Nigeria. The party also sought to capitalise on vague sentiments of Cameroonian 'brotherhood'. The vagueness of the constitutional proposals made by Ahidjo and Foncha permitted the KNDP to proclaim that the Southern Cameroons would enjoy a large degree of autonomy and that its language and cultural heritage would be maintained. The CPNC singled out terrorism in the Republic of Cameroon in order to scare Southern Cameroonians from voting for reunification. It also tried to impress upon the electorate that reunification would mean a complete change in language, system of government and way of life (Welch 1966: 231-33; Johnson 1970: 147-52). Both parties appealed to ethnic sentiments and loyalties. For example, the KNDP used to ask the audience at their rallies in the North West whether they were going to vote in support of $\mathrm{Dr}$ Endeley, a Bakweri, or for Foncha, a Bamenda man. Foncha made good use of his position as prime minister and the fact that the KNDP was the party in power. He often underlined that a vote for reunification was a sign of loyalty to the government. The KNDP sometimes even obstructed the campaigning of the CPNC, especially in the North West. Other tactics employed to win votes included making unsubstantiated promises, telling lies, bribing people and distributing gifts to the electorate (Ebune 1992: 182-91). According to Awasom (2000: 111), the KNDP propaganda machinery was heavily supported by Francophone businessmen and politicians in the southwestern quadrant who favoured reunification with the ethnically-related Anglophone population in their pursuit of economic and political power.

The KNDP emerged victorious from the plebiscite held on 11 February 1961: 233,571 Southern Cameroonians voted for reunification with the Republic of Cameroon while only 97,741 voted for integration into Nigeria (see Table 2.1). The ratio of votes for and against reunification, however, was significantly higher in the North West (3.5 to 1) than in the South West (1.5 to 1) (Welch 1966: 235). The CPNC leaders protested strongly to the United Nations about the results, which to them were very unsatisfactory. The party held that ethnic elements had played a vital role in influencing opinions during 
Table 2.1

Results of the 1961 Southern Cameroons Plebiscite

Plebiscite Districts Number of votes
for Nigeria

North West Province

Bamenda Division

East

8,073

1,822

Central West

1,230

Central East

529

467

220

Total

12,341

1,485

3,644

1,518

2,137

8,784

Number of votes

North

East

West

for Cameroon

Total

5,962

3,845

5,059

7,051

21,917

18,839

17,858

18,027

18,193

16,142

19,426

108,485

North

Central

South

7,322

3,211

13,133

3,449

27,115

South West Province

Victoria Division

Southwest

2,552

1,329

4,744

3,291

Northwest

11,741

1,917

5,896

4,288

2,921

15,022

Total

9,466

14,738

6,105

Southwest

32,733

27,600

Mamfe Division

West

2,039

8,505

North

5,432

6,410

South

685

8,175

East

1,894

10,177

Total

10,050

33,267

Grand Total

97,741

233,571 
the plebiscite. It called on the United Nations to interpret the results on an ethnic basis. Where an ethnic group had voted in favour of union with Nigeria or the Republic of Cameroon, it should be allowed to join the country of its choice. The appeal was rejected and the United Nations accepted the results as they were.

Ahidjo was equally shocked by the plebiscite results but for a different reason. The exact opposite of what he had hoped for had happened. While the Southern Cameroons had opted to join Francophone Cameroon by a very wide margin, the British Northern Cameroons, which was of the same ethnic extraction as his home region, had voted in a separate plebiscite for integration into Nigeria. The plebiscite results thus appeared to weaken rather than strengthen Ahidjo's power position. He particularly feared an alliance between the Southern Cameroons and the ethnically-related Francophone opposition in the southwestern quadrant after reunification.

Ahidjo's first reaction to the plebiscite results in the British Northern Cameroons was that 'foul play had been committed and the results had been falsified' (Le Vine 1964, 1971). He immediately lodged a complaint with the United Nations to the effect that the plebiscite did not represent the free choice of the British Northern Cameroons voters. In one of its sessions on 21 April 1961, the United Nations General Assembly Fourth Committee rejected his complaint and approved the February plebiscite results. It then invited the administering authority and the governments of the Southern Cameroons and the Republic of Cameroon to start urgent negotiations with a view to finalising before 1 October 1961 'the arrangements by which the agreed and declared policies for a union of the Southern Cameroons and the Republic of Cameroon would be implemented' (Mukong 1990: XVIII).

The Fourth Committee proposed the appointment of three constitutional and administrative experts nominated to assist in the discussions. Given their conflicting views on the details of the federal constitution, one would have expected Foncha and Ahidjo to welcome the United Nations' initiative aimed at assisting them to finalise a constitution for the union. Paradoxically, Ahidjo, with the tacit support of Foncha, turned down international assistance on the grounds that the two Cameroons were already engaged in constitutional talks and that the involvement of international experts would constitute an unnecessary interference in a strictly Cameroonian affair. Foncha's naive complicity in this matter proved to be fatal to the Southern Cameroonians as subsequent events proved (Awasom 2001). 


\section{The 1961 Foumban constitutional conference}

Following the United Nations General Assembly's approval of 1 October 1961 as the date of termination of British trusteeship and reunification, very little time remained for the complex negotiations to establish a new constitution.

It soon became evident that Foncha's bargaining position during the negotiations had been seriously weakened by the lack of any substantial and meaningful British support. Since the Southern Cameroons had voted for union with the Republic of Cameroon against the British-preferred option of integration into Nigeria, Britain decided to play second fiddle in the postplebiscite discussions, being more anxious to quit the territory on 1 October 1961, the date prescribed by the United Nations, than to lead the Southern Cameroonian politicians through the intrigues and complexities of constitutionmaking. The British government, in a spirit of abandonment, appeared not to care whether the new constitution sufficiently protected the Anglophone minority or would survive the post-reunification era. During a session of the British parliament in August 1961, Lord Thompson, a member of the opposition, pointed out Britain's indifference to the constitutional talks between the Anglophone and Francophone leaders:

There can be no doubt that given the difficulties facing the two countries, with different systems of administration and different languages, federation is the only practical system, certainly in the interests of the Southern Cameroons. But there is no clarity as to how far this is a definite commitment from the Republic of Cameroon. I am wondering what our government is doing to ensure firm agreement in black and white that there should be a proper federal system, which will allow the two territories to work out their future harmoniously and gradually. ${ }^{6}$

The British Under-Secretary of State for the Colonies, Mr Hugh Fraser, replied that the 'actual constitutional arrangements [were] essentially matters for Cameroonians themselves', ${ }^{7}$ clearly indicating that Britain had washed its hands of the Southern Cameroons and ceded the territory to the French sphere of influence.

In contrast, Ahidjo could definitely count on France's support. France was able to win Britain over to the view that the union of the two Cameroons was bound to take place on 1 October 1961 and that any imperfections in the federal constitutional draft should be shelved for the post-reunification period (Awasom 2001). Britain subsequently decided to put pressure on the KNDP leadership to reach a modus vivendi with the other Cameroon, regardless of the

6 House of Commons debate, 1 August 1961, pp. 1337-38.

7 Ibid., p. 1347. 
form or content. This development was an unfortunate turn of events, compelling the KNDP to come to terms with the Ahidjo government at all costs.

Acting almost single-handedly, Foncha and his KNDP lieutenants still managed to oppose Ahidjo's proposals for a highly centralised federal state for some time, persistently championing the creation of a loose federal union that would allow the two Cameroons to preserve their specific identities. According to Awasom (2001), it was only after the failure of the Buea Tripartite Talks of 15-17 June 1961 that Foncha finally acquiesced in a secret deal with Ahidjo to the introduction of a highly centralised federal state and the transfer of sovereignty to Ahidjo after reunification in exchange for important portfolios.

The Buea Tripartite Talks preceded the Bamenda All-Party Constitutional Conference that was scheduled to take place on 26-28 June 1961. This conference would bring together the Southern Cameroonian political and traditional leaders for the purpose of drafting a comprehensive set of proposals as a basis for future negotiations with representatives of the Republic of Cameroon. A few days before the conference, Ahidjo handed his constitutional proposals to Foncha, asking him to discuss them with his cabinet members. Foncha came under fire from the other KNDP ministers for his secret scheming with Ahidjo and his acceptance of the majority of Ahidjo's proposals, which appeared to be a breach of the KNDP plebiscite pledge. Counter proposals were produced which adhered more closely to the loose federal union that the KNDP had propagated during the plebiscite. During the Bamenda conference, Foncha refused to report on the outcome of his secret negotiations with Ahidjo for fear that the opposition would sabotage the conference and derail the constitutional process. As a result, the delegates eventually adopted proposals for a loose federation that were greatly at variance with Ahidjo's proposals.

The Southern Cameroons proposals included a ceremonial rather than an executive head of state; a bicameral federal legislature; a governor or head of each state, with a prime minister as the head of an accountable government in each of the component states; separate state and federal citizenship; the allocation of a wide range of legislative powers to the states, particularly in the early stages after union though with an acknowledgement that some of these could be transferred to the central government at a later date; the entrenchment of a large number of provisions by means of a procedure that would make amendment difficult, and depending either on the consent of a two-thirds majority in each state legislature or approval in separate state referenda; the reservation of a certain quota of ministerial portfolios at the federal level for each state; the transfer of the federal capital from Yaoundé to Douala; the adoption of French and English as the federation's official languages; specific provisions for the protection of fundamental human rights; power vested in the president to veto legislation considered detrimental to the rights of states, or of 
minorities within them; as well as matters of some particular concern to the Southern Cameroons itself, such as the maintenance of the general legal system and of the state, the retention of the House of Chiefs, and safeguards for the continued existence of the customary court system (see Rubin 1971: 111-12). Foncha was fully aware of the fact that Ahidjo would reject these proposals but he went ahead with sending them to Ahidjo to make him realise that they expressed the popular will of the Southern Cameroonian people and not just the position of the KNDP government.

It was Ahidjo who chose the timing and setting of the constitutional conference between the Anglophone and Francophone representatives. Constitutional talks were to be held from 17-21 July 1961 in Foumban, the capital of the Bamun, an ethnic group in present-day West Province in Francophone Cameroon that is closely related to ethnic groups in the neighbouring North West Province of Anglophone Cameroon.

Mr N.N. Mbile (2000: 166-67), who was a Southern Cameroonian representative at this conference claims that Ahidjo had deliberately selected the town of Foumban for the occasion:

Foumban looked ideal for this historic come-together. Free from all the unrest that had scared Southern Cameroonians and blessed with a most congenial climate and people, the Francophone authorities had picked the place deliberately for the occasion. The entire town had been exquisitely cleaned up and houses splashed with whitewash. Charles Okala, the Foreign Minister, an amiable host ... had flown in two orchestras, one from Yaoundé, the other from Douala. Our hosts had taken meticulous care to provide the best lodging possible. Food was good and receptions lavish. As a matter of fact, we could see the weeks of effort put in by our hosts to cement the impression that the term 'brothers' went deeper than on mere lips and the climate in Foumban real or artificial went far to convince us that despite the stories of 'murder and fire', there could be at least this island of peace, east of the Mungo. ${ }^{8}$

The Foumban Constitutional Conference posed a political risk for both Foncha and Ahidjo. Both statesmen were publicly and privately committed to a federal union, and a new federal constitution had to emerge from some form of political consultation. Just before the conference, in an effort to minimise frustrations, discord and the loss of tempers, they struck a secret deal in which no direct constitutional debates would take place between the two delegations during the conference (Awasom 2001). Instead of debate, there would be a brief reception in honour of the Southern Cameroonian delegation given by President Ahidjo. Ahidjo would talk privately to Foncha first and then receive the delegates of the Southern Cameroons one at a time. The Foumban conference would therefore be brief and the delegates would then return home. Thereafter,

8 The Mungo is a river dividing Anglophone and Francophone Cameroon. 
reunification negotiations for a proper federal constitution would be worked out, and the consensual constitution would be ratified by the legislatures of the new federation.

On the first day of the conference, 17 July, the Southern Cameroonian delegates were shocked when Ahidjo communicated to them that he would prefer to talk to them individually instead of holding a bi-national constitutional debate. They angrily turned down this proposal outright, thus unknowingly but successfully torpedoing the secret agenda of Ahidjo and Foncha. Ahidjo then reluctantly agreed that the Anglophone delegates could discuss the constitutional proposals, while the Francophone delegates would await the results of the Anglophone deliberations. Both delegations were to meet in a final session that was allowed to last only one and a half hours.

Ahidjo then made the translated draft constitution to the Southern Cameroonian delegates available for study. It was presented as a simple revision of the constitution of 4 March 1960 of the Republic of Cameroon. Most Southern Cameroonian delegates felt embarrassed when they saw for the first time Ahidjo's constitutional package for a strongly centralised federal state, with only residual powers for the federated states. Overwhelmed by brotherly sentiments, however, they ignored their embarrassment and agreed to examine the proposals on the spot. In retrospect, it is now evident that Ahidjo had few illusions about the eventual relationship between the two territories: the Francophone territory, with a much larger size and population and a much higher level of economic development than the Anglophone one, had to be the dominant element in the new union. And even more importantly, by the time of these negotiations, the Southern Cameroons was obliged to achieve its independence by joining the sovereign Republic of Cameroon, enabling Ahidjo to dictate the terms for federation by capitalising on his territory's 'senior status'. Ahidjo refused to consider the Bamenda constitutional proposals and did not even hesitate in proclaiming that he would accept recommendations concerning his own constitutional proposals but that he and his delegation would be the final arbiters of what would be accepted (Stark 1976: 112; Fonge 1997: 184-85).

The Southern Cameroons delegation examined Ahidjo's proposals in three sessions and produced a number of recommendations aimed at mitigating the full impact of these proposals for a highly centralised regime on the institutions of the future Anglophone state. By no means all their recommendations were dismissed but the most important ones - those intended to safeguard the greatest degree of autonomy for each state - were clearly overwritten.

The final version of the federal constitution changed the names of the two states that came to constitute the Federal Republic of Cameroon: the former Republic of Cameroon would henceforth be called the Federated State of East 
Cameroon, and the former Southern Cameroons would be called the Federated State of West Cameroon. ${ }^{9}$ The official languages of the federal republic would be French and English. To the consternation of Anglophones, the final version of the constitution appeared to deny the equal status of both languages, stipulating in Article 59 that 'the revised constitution shall be published in French and English, the French text being authentic'. Dual citizenship, as proposed by the Southern Cameroons delegation, was rejected by Ahidjo but he eventually agreed to insert a clause into the constitution, affirming the federal state's adherence to the fundamental freedoms set out in the Universal Declaration of Human Rights and the Charter of the United Nations (Article 1). The most important constitutional arrangements were the following:

The constitution granted almost total authority to the federal state. According to Article 5, a number of tasks were to come under federal jurisdiction immediately upon independence, such as foreign affairs; the internal and external security of the federal state; development planning; foreign aid; the monetary system; taxation; civil, criminal, and contract law; and secondary and post-secondary education. Article 6 stipulated a comprehensive list of further tasks that were to become federal matters as time went on. No specific list of tasks that were to fall permanently within the jurisdiction of the state governments was provided. Article 38 reads: 'Matters other than those specified in Articles 5 and 6 and other than those which under the present constitution are to be subject of a federal law shall lie exclusively within the competence of the federated states'. The customary courts of West Cameroon and primary education had some constitutional warrant for being taken as state tasks. Other tasks left to the states in the early years, by convention rather than constitutional prescription, were local government, social welfare, archives and antiquities, agriculture, forestry, cooperatives, internal trade, state public works, and other minor projects. Moreover, the constitution provided for no autonomous financial resources for the federated states, thus depriving them of any means of exercising real power (Ardener 1967: 310; Johnson 1970: 219; Benjamin 1972: 82).

The constitution created a presidential regime at the federal level. In contrast to the Bamenda proposals, the president of the federal republic was to be an active, powerful chief executive rather than a mere figurehead. He was to be head of state, head of the federal government, and head of the armed forces. He was responsible for the conduct of the affairs of the federal republic, and was not accountable to the legislature for his actions. Since no real separation of powers was provided for by the constitution, the president could play an

9 The constitution of the Federal Republic of Cameroon is reproduced in Enonchong 1967: 253-66. 
important role in the legislative process through his ability to propose legislation or to delay or prevent the passage of legislation he did not like. Moreover, in many instances he had the power to legislate by decree and without reference to the national assembly. He could even declare a state of emergency on his own and rule entirely by decree. Nor did he need to seek legislative approval for his appointments. He appointed ministers, governors, judges and high-level civil servants, and they were entirely dependent on his favour to remain in office. It is not surprising, therefore, that the constitution has been judged in terms of its contribution to 'presidentialism' rather more than for its accomplishments in federalism (Rubin 1971).

The president was to be assisted in his duties by a vice-president. On the recommendation of the Southern Cameroons delegation, it was laid down in Article 9 of the constitution that the president and vice-president must not be natives of the same federated state. Both were to be elected on a single list by universal suffrage and direct secret ballot. The function of vice-president was held by Anglophones (Foncha, 1961-70; Muna, 1970-72) until 1972 when it was abolished following the creation of a unitary state. It should, however, be pointed out that the subordinate position of the vice-president was made very clear by the constitution. Undoubtedly, he had some potential powers - he succeeded to the presidency automatically if that office became vacant for whatever reason, although he was only to remain in office until a new president was elected not more than fifty days later - but he was not given any specific powers of his own.

While Article 4 of the constitution defined federal authority as residing in the federal president and the federal national assembly, the latter played a far inferior role within the framework of federal power. In the framing of the constitution, the Southern Cameroons proposal for a bicameral legislature was rejected, and a unicameral system was adopted. The choice was justified on the grounds of economy and efficiency but it is most likely that Ahidjo saw the proposal as a threat to the centralised character of the constitution, as well as a means of impeding the federal government. Representation of the federated states in the federal assembly was proportionate to the population of each state, and each member was to represent 80,000 citizens. On the basis of the figures given in the constitution, there were to be fifty seats in the assembly, forty of which represented East Cameroon and ten West Cameroon. Both the number and the duration of the assembly's sessions were limited by the constitution: it was to meet twice a year for sessions that were not to exceed thirty days, although it could also be convened for an extraordinary session of not more than fifteen days at the request of the president or of two-thirds of its members. The role of the legislature was both limited, in the sense that specific legislative powers were conferred on the president, and diluted in the sense that the 
president was able to exercise powers concurrently with the legislature on those tasks not exclusively set aside by the constitution for the attention of the national assembly.

Curiously, Ahidjo eventually allowed a Southern Cameroons recommendation to be incorporated into the constitution that created a potential safeguard against the adoption of federal legislation harmful to one of the federated states. Article 18 created a procedure whereby the president might require a bill to be read a second time, either of his own accord or at the request of the prime minister of either federated state. At the second reading, the bill had to receive the approval of a majority of the national assembly members from each federated state. This element of a second reading was one of the few respects in which the constitution envisaged curtailment of the powers of the federal authority through the actions of state representatives. Although this provision could have made a significant contribution to the safeguarding of West Cameroon interests, it was never actually applied. Relations between West Cameroon and the federal government in the first five years were mediated mainly by the powers of decree of the president, and from 1966 all West Cameroonian representatives in the national assembly belonged to the Cameroon National Union (CNU), the single party in the federal republic.

The constitution provided for a state structure whereby a presidential regime at the federal level was combined with a parliamentary regime at the level of the federated states. Although the federated states had almost no powers, they were furnished with separate constitutions outlining the character of their respective institutions..$^{10}$ Both states had a parliamentary form of government, with governments collectively responsible to their legislatures. Remarkably, the constitution made no major modifications to the formal governmental structures that had existed in the two states prior to reunification. West Cameroon retained its House of Assembly (renamed the West Cameroon Legislative Assembly), its House of Chiefs, and its ministerial system, complete with a prime minister and cabinet (ministers in both states are now called secretaries of state). East Cameroon retained its own legislature, unaltered save in name (from National Assembly to East Cameroon Legislative Assembly), and its ministerial system of prime minister and secretaries of state. Not wishing to create an autonomous power base for chieftaincy in the federal republic, Ahidjo reluctantly agreed to the Southern Cameroons delegation's demand for the preservation of the bicameral character of its state legislature in recognition of the important role Anglophone chieftaincy had played in the process of reunification (Konings 1999b), but he bluntly refused to create a House of

10 The constitutions of the federated states of East and West Cameroon are reproduced in Enonchong 1967: 267-91. 
Chiefs in East Cameroon where none had existed before reunification. As a result, a potentially dangerous disequilibrium was created between the two federated states, which could in the long run have frustrated the chiefs in East Cameroon. No wonder that Ahidjo was quick to abolish the West Cameroon House of Chiefs after the promulgation of the unitary state in 1972.

The constitution created a judicial system that largely reflected the governmental system established in the federal republic. The court system in both federated states remained unaltered, and the courts continued to function on the basis of the pre-unification legal systems based on French principles and procedures in East Cameroon and on the British version in West Cameroon. At the top of the legal structure, however, the constitution introduced two new courts: the Federal Court of Justice to handle appeals from the highest state courts, to adjudicate interstate or state-federal disputes, and to give advisory opinions to federal authorities in certain limited situations; and a special panel, the High Court of Justice, to try cases involving high treason, conspiracy against the state, or crimes committed by the highest-level federal or state officials.

The final version of the constitution left no room for legal secession from the federation, although some Southern Cameroons delegates had wanted a proviso inserted into the constitution sanctioning peaceful withdrawal from the federation.

The constitution laid down a federal system significantly different to the one Foncha had promised Southern Cameroonians. The majority of the Anglophone elite felt that the dominant Francophone majority had imposed its will on the Anglophone minority. What embittered them even more was that Ahidjo neither resumed the constitutional talks, as had been proposed at Foumban, nor submitted the federal constitution for final approval to a constituent assembly composed of Anglophone and Francophone representatives. The final version of the constitution was approved only by the parliament of the Republic of Cameroon on 1 September 1961, one month prior to reunification. That is why the present Anglophone movements declared in 1993 that 'the union between the Southern Cameroons and the Republic of Cameroon had proceeded without any constitutional basis' (All Anglophone Conference 1993).

\section{Conclusion}

Our narrative of the complex historical trajectory of Anglophone Cameroon towards reunification and federation with Francophone Cameroon has thrown some doubts on the widespread belief among Francophones that Southern 
Cameroonians warm-heartedly and freely embraced reunification and federation.

This chapter has shown that for a long time reunification remained a vague ideal, the political and economic implications of which were never clearly spelt out. Foncha had picked it up merely as an electoral slogan to combat Endeley's new position of advocating the territory's integration into the Federation of Nigeria. But even Foncha tended to perceive reunification not as an immediate goal but rather as an issue to be negotiated after the territory's prior separation from Nigeria and a period of continued trusteeship or independence. Immediate reunification became one of the two alternatives in the 1961 plebiscite only after the Southern Cameroonian political elite had failed to agree on the future of the Southern Cameroons and the United Nations had refused to grant the territory an extended trusteeship or independent status - options considered to be politically undesirable and economically unattractive.

The 1961 plebiscite campaign that was waged between Foncha's ruling KNDP party and Endeley's CPNC party was probably the most decisive event in the history of Southern Cameroons. The campaign clearly demonstrated that most Southern Cameroonians found neither of the two alternatives acceptable. They were inclined to reject integration into Nigeria fearing persistent Igbo domination, but they were also not sure of reunification with Francophone Cameroon, a territory with a different cultural heritage and involved at that time in a violent civil war. They failed to see why a third alternative - full independence - was denied them by the United Nations and the Administering Authority. That they eventually did vote for reunification was due not only to the fact that they preferred reunification to the sole alternative, joining Nigeria, but also to a number of other factors including lack of information or even misinformation of the political and economic implications of reunification, ethnic loyalties to the party in power, and Foncha's strong assurances that reunification would imply a loose form of federation guaranteeing Southern Cameroons a large degree of autonomy, equal partnership and preservation of its cultural heritage.

The constitutional talks after the plebiscite did not produce the form of federal state that Southern Cameroonians expected. The Foumban conference was presented to the electorate as a historic occasion where estranged brothers were to mutually agree upon the constitution of a reunified Cameroon, but it turned out to be an event largely staged to ratify earlier understandings between Ahidjo and Foncha. During the conference, Ahidjo used his superior bargaining power to control the negotiations, accepting only those suggestions and amendments of the Southern Cameroonian delegation that posed no threat to his well-prepared draft constitution. By the end of the conference, Foncha and the KNDP had nothing to offer Southern Cameroonians except what they had 
promised the electorate they would guard against: a highly centralised form of federation.

Some Anglophone authors, like Ngoh (1996) and Njeuma (1995), place the blame for these developments first and foremost on Foncha and other KNDP leading figures whom they accuse of negotiating poorly with Francophone counterparts. In their view, Foncha was naive, secretive and egoistic, and failed to involve other Anglophone parties, public opinion and experts in the negotiations with Ahidjo on the nature of the federal constitution. This type of interpretation is too restrictive and one-sided and does not take into account a number of other factors that militated against the introduction of a loose form of federation safeguarding the protection of the Anglophone minority and the preservation of the Anglophone identity, notably the serious time constraint facing the Foncha-Ahidjo constitutional talks before and after the February 1961 plebiscite, the prevailing circumstances of insecurity in the Republic of Cameroon and the still precarious power position of Ahidjo, the alien aspects of federalism to most Francophones, the abandonment of the Southern Cameroons by the British and the continuing strong support of the French for Ahidjo, the absence of UN experts, and, last but not least, the internal divisions among the Anglophone elite. 


\section{The development of an Anglophone consciousness during the federal and one-party unitary state, 1961-1990}

Having succeeded in imposing a highly centralised form of federalism upon the newly created union between East and West Cameroon, the President of the Federal State, Ahmadou Ahidjo, gradually and cautiously undertook the realisation of his ultimate goal: the establishment of a strong, unitary state. In this chapter, we highlight the various strategies he used to achieve this objective including his attempts to weaken the federal structure of the new state and to undermine the autonomy and identity of West Cameroon, his formation of a single national party in the entire federation, his replacement among the West Cameroonian political elite of supporters of state autonomy by advocates of increasing federalisation of state powers, his creation of ethno-regional clients and, last but not least, his use of severe repression.

The outcome of his moves appears to have been ambiguous. On the one hand, they succeeded in establishing a unitary state in 1972, taking advantage of the internal divisions among the Anglophone political elite and their personal ambitions in the rapidly changing power constellation in the federation. On the other hand, they created disillusion among the majority of Anglophones who strongly resented the loss of their region's autonomy and the Francophone hegemonic and assimilative tendencies. Gradually, one could observe the emergence of an Anglophone consciousness: a feeling among 
Anglophones that their community with its distinct colonial legacy was subject to marginalisation, exploitation and assimilation by the Francophone-dominated state and even by the Francophone population as a whole. During the Ahidjo period of the one-party unitary state, fear of violent treatment of those who dared to contravene its policies dissuaded Anglophones from openly protesting. It was not until a limited degree of liberalisation was introduced by Ahidjo's successor, Paul Biya, that Anglophones started voicing their grievances.

\section{Anglophones and the dismantling of the federated state of West Cameroon, 1961-1972}

From the birth of the federation on 1 October 1961 onwards, the President of the Federal State, Ahmadou Ahidjo, started weakening the federal structure of the newly created state and undermining the autonomy and identity of West Cameroon.

As already seen in Chapter 2, the 1961 federal constitution granted few powers to the federated states. Making use of the constitutional provisions, Ahidjo succeeded in bringing most of these state powers under federal jurisdiction by 1967 (Ardener 1967; Stark 1976). By claiming nearly all the most important functions of state business itself, the federal government ensured the redundancy of the governments of the federated states and denied them any raison d'être, except a political one, and even that was purely cosmetic.

Moreover, the 1961 federal constitution had not provided for any autonomous financial resources for the federated states. West Cameroon was to give up its sources of customs and other revenues and was to be financed by federal subventions until a revenue allocation prescription could be fixed. However, such a formula was never found. Although the first prime minister of West Cameroon, J.N. Foncha, regularly requested the installation of a revenue allocation committee during the first years of the federation's existence, Ahidjo simply refused to do so. As a result, West Cameroon continued to be dependent on the federal government for subventions from the beginning to the end of the federation to finance its activities. This situation served as a kind of pressure for the further federalisation of state functions. As Ardener (1967: 317) put it: 'The necessity to apply annually for federal help over the years made the economic arguments for the federalisation of many state services seem irresistible'.

1 See, for instance, the letter from the Prime Minister of West Cameroon to His Excellency Ahmadou Ahidjo, President of the Federal Republic of Cameroon, Yaoundé, dated 9 April 1962, in BNA, File Oc (1962) 3, Discussions with the President [Secret]. 
Another issue that was soon to become a source of conflict between the West Cameroon leaders and President Ahidjo was the question of territorial administration. The Anglophone delegation in Foumban gave little thought to the constitutional clause that dealt with federal administration and so the proposal advanced by the Francophone delegation was adopted. Soon after reunification, Ahidjo, in exercising the powers conferred upon him by the constitution, passed decrees that enhanced federal supervision and control over the political and administrative life of West Cameroon. Decree no. 61-DF-15 of 20 December 1961 stipulated that the territory of the federal republic be divided into six regions. Each of the regions was placed under an inspector of administration, a civil servant appointed to the post by the president and directly responsible to him. These federal inspectors were charged with 'representation of the federal government in all acts of civil life and in judicial matters, supervision of the enforcement of federal laws and regulations, and the maintenance of order according to the laws and regulations in force', having at their disposal the police force and gendarmes, as well as federal services. Under this system, West Cameroon was designated as only one of six regions. Ahidjo thus introduced an administrative system that basically ignored the federal nature of the country. The duality of authority it created in West Cameroon aimed at further weakening the authority of the West Cameroon government. In 1962, Foncha strongly protested to Ahidjo against this administrative system:

By this administrative division, West Cameroon has the same status as any of the five administrative regions into which East Cameroon is divided. We regret that this is inconsistent with the status of West Cameroon as a state in our federation of two states. Furthermore, we cannot at the same time regard West Cameroon as a state in the Federation and as a province in the same Federation. The powers given to the Inspector of Administration are far more extensive than those of either the Prime Minister of West Cameroon or the House of Assembly and Government. This system is anachronistic and in fact a resuscitation of what existed in the early colonial system. It is also derogatory to the authority and dignity of our Prime Minister and our government. It is tending to change the system of administration in this state and is causing a great deal of frustration and disappointment among citizens of West Cameroon. It is adversely affecting the operation not only of the state government but also of the federal machinery.

Unfortunately, the Francophone federal inspectors in West Cameroon were generally hungry for power and acted as though they were senior to the prime minister of West Cameroon. There was a running battle for jurisdiction

Top Secret Representation to His Excellency, the President of the Federal Republic of Cameroon by the West Cameroon Government requesting the Rectification of Certain Matters Tending to Hinder the Smooth and Effective Functioning of the Federal Republic, dated 4 October 1962, in ibid. 
between the two officials until the late 1960s (Stark 1976; Johnson 1970; Fonge 1997). In addition, the federal inspectors were not only beyond the control of the state government but also exercised authority over local officials, some of whose duties fell within both the federal and local state's jurisdictions. All this created much confusion and, at times, tension. Moreover, as federal powers expanded, these officials, like district officers, spent more and more time on federal rather than on state work.

And last but not least, the federal inspector was authorised to use the armed forces, gendarmes and police to reinforce his authority if he deemed such action necessary. Since the army and gendarmerie were federal forces, their presence in West Cameroon gave the federal inspector an edge over West Cameroon state officials, who could not employ these forces without approval from Yaoundé. The overzealous gendarmes themselves gave the impression that they were above the West Cameroon state authorities, a matter that was reinforced by the fact that Ahidjo declared a state of emergency in large parts of West Cameroon immediately after reunification for the claimed purpose of combating the UPC rebels who, he believed, used the territory of the ethnicallyrelated Anglophone peoples as a safe haven when attacking Francophone targets. On occasions, gendarmes stopped and searched top West Cameroon government officials, parliamentarians and even secretaries of state by the roadside for no apparent reason other than to demonstrate their power over these officials. The demeanour of the gendarmes generated considerable public protest in Anglophone Cameroon but it also indicated that effective power was in the hands of the federal inspector of administration who had direct control over the gendarmes (Fonge 1997: 190-91).

Simultaneously, Ahidjo put in place policies aimed at eradicating some of the Anglophone economic and cultural heritage and integrating the Anglophone community more and more into the Francophone-dominated federal state. Ardener (1967: 290) correctly observed that the story of the first few years of federation was 'one of various attempts to link West Cameroon in some effective way to its partner, and of the gradual discovery of new ways of doing this by the East'.

In 1962 Ahidjo replaced the Nigerian pound in West Cameroon with the Communauté Française d'Afrique (CFA) franc, which then became the only legal tender for the whole country. The exchange rate was 692 CFA francs to the pound. This occurred without any consultation of West Cameroonian leaders. One of the West Cameroon newspapers asserted that the pre-reunification rates had been 800 CFA francs to the pound. As a result, there was a sharp and painful decline in the standard of living in West Cameroon (Ndongko

3 The Cameroon Times, 18 June 1962, p. 1. 
1975). In the same year (1962), traffic in West Cameroon was made to drive on the right-hand side of the road in conformity with the practice then in existence in East Cameroon. In 1964, Ahidjo replaced the West Cameroon imperial system of weights and measures with the East Cameroon metric system. Of even greater significance was Ahidjo's termination of West Cameroon's ties with the Commonwealth of Nations and the sterling bloc. In their October 1960 Joint Declaration (see Chapter 2), Ahidjo and Foncha had agreed that a reunified Cameroon would at no time be a part either of the French Community or the British Commonwealth. Nevertheless, Ahidjo soon thereafter signed a series of cooperation agreements and treaties with France, which directly tied the then Republic of Cameroon to France (Joseph 1978: 16). Soon after reunification, Ahidjo cut West Cameroon's ties with the Commonwealth but left the Franco-Cameroonian accords in force. In 1963, Prime Minister Foncha reminded President Ahidjo that:

All agreements made between Britain or any other foreign country and the then Southern Cameroons as well as similar agreements or treaties made between France or any other foreign power and the then Republic of Cameroon, which were devolved on the Government_of the Federal Republic of Cameroon upon reunification should now be reviewed.

Ahidjo simply ignored Foncha's reminder. One effect of the withdrawal from the Commonwealth was the loss of 'Commonwealth preferences' for certain West Cameroonian export products. Those most threatened by the loss of preferences were West Cameroonian banana producers who had previously been allowed to export their bananas to Britain at a price that was 15 per cent higher than on the world market (Ngoh 1990: 193-94; Ndongko 1975; Konings 1993a). Another effect was the need in West Cameroon to shift away from British and Nigerian imports to French and East Cameroonian imports. Johnson (1970: 331) estimated that the difference in prices between the two states might have been as high as 100 per cent, a fact that severely affected the West Cameroon population. Moreover, the two West Cameroonian ports of Victoria (Limbe) and Tiko became virtual ghost towns as most imports and exports to and from West Cameroon were diverted to the port of Douala in East Cameroon (Ngwafor 1989). To facilitate the transfer of West Cameroon export products through Douala, the Tiko-Douala Road, known as the Reunification Road, and the extension of the Douala-Mbanga railway line to Kumba were opened in 1969. In addition, the closure of West Cameroon Electric Power (Powercam),

4 See the letter from the Prime Minister of West Cameroon and Vice-President of the Federal Republic, Honourable John Ngu Foncha, to His Excellency Ahmadou Ahidjo, President of the Federal Republic, dated 14 September 1963, in Personal Library of S.T. Muna, File no. 98 (57), KNDP correspondence. 
the company that supplied (relatively cheaper) electricity throughout West Cameroon, and its replacement with the more costly Société Nationale d'Electricité (Sonel) from East Cameroon were seen by most Anglophone Cameroonians as another attempt to exploit West Cameroon and make it economically dependent on East Cameroon (Kofele-Kale 1987).

Ahidjo's attempts to undermine and Gallicise the Anglophone cultural heritage met with stronger resistance in West Cameroon than his attacks on West Cameroon administrative and economic autonomy, as they were perceived as a direct onslaught on the Anglophone identity. Foncha, in particular, had been deeply concerned about the protection of cultural autonomy at the Foumban conference, and he consistently maintained this attitude throughout his time as prime minister of West Cameroon (1961-1965). As a consequence, Ahidjo's attempts to harmonise the educational and legal systems in favour of the Gallic system largely failed (Chem-Langhëë 1997; Fonge 1997; Stark 1976). One minor reform was the harmonisation in 1965 of the school calendar by shortening that of elementary schools in Anglophone Cameroon from eight to seven years. Although English and French were the constitutionally designated official languages, Anglophones proved incapable of warding off the decline and corruption of English. The Ahidjo government's failure to make any real efforts to implement a policy of bilingualism in a country where Anglophones formed less than one quarter of the population 'naturally tilted the scales in favour of French ascendancy' (Chumbow 1980: 298). The French language became increasingly the language of the administration, police, army, university, and so on. In short, it became the language of oppression and repression. Little wonder that Anglophones had the impression that English was only an official language of secondary importance and that official bilingualism was merely an attempt to convert English-speaking Cameroonians into Francophones, all the more so since Ahidjo himself never bothered to learn English, preferring to command directly in French or to adopt pidgin English in conciliatory moments.

These developments created disillusion with the federation among the West Cameroonian population. In 1967, the following observations were made about Anglophone attitudes towards the federation:

Though in the long run the advantages would well outweigh the disadvantages, right now West Cameroonians tend to feel they are getting a raw deal. The influence of the French-speaking East is now, for the first time, really being felt: not only are Yaoundé's powers considerable, but prices have risen considerably; French and Common market goods are replacing the familiar British and Nigerian goods; the power of East Cameroon is being felt. Good or bad, if West Cameroonians were 
today given the choice they might well choose independence - from Nigeria and the French-speaking East.

It is evident from our narrative so far that West Cameroonian political leaders, like Foncha, regularly protested against the growing loss of West Cameroonian autonomy and identity, and the blatant lack of West Cameroonian participation in the decision-making process during the first years of the federation's existence. The most articulate spokesman for West Cameroonians was to become Dr Bernard Fonlon, one of the few highly_educated leaders of the ruling KNDP and an author of international reputation. ${ }^{\text {Fonlon had studied }}$ at the Sorbonne, Oxford and the University of Ireland where he obtained a PhD. He was generally regarded as the most accomplished Cameroonian of either colonial culture. He had been the secretary at the Foumban conference and later joined Ahidjo's staff at the presidency. Owing to his educational achievements, his fluency in both English and French and his political-administrative career, Fonlon was highly respected by both West and East Cameroonian political leaders. His influence was enhanced by his election in the spring of 1964 to the Federal National Assembly and his subsequent appointment by Ahidjo to the post of deputy minister of foreign affairs. Fonlon had helped in founding the bilingual cultural journal Abbia. [n March 1964 he published an article in it entitled 'Will We Make or Mar?" in which he condemned the unequal position of West Cameroon in the federation:

The two specimens of culture that are met in the country today are not of equal strength. The Anglo-Saxon is weaker, and this, for obvious reasons. The result of this many-sided inequality is that, in this federation ... the power to introduce policy, to shape the course of events in things political, economic, social and cultural, lies, to all intents and purposes, entirely in the hands of East Cameroonians.

In three years of unification, sundry uses and institutions, thanks to articles five and six of the federal constitution, have now come from the East to the West. Furthermore, in West Cameroon, they now drive on the right, the franc has replaced sterling as legal tender, the school year has now been streamlined to fit that of the East and the scientific metric system has now replaced the unwieldy British measures.

But I have searched in vain for one such use or institution brought into the East through West Cameroon. Outside its own federal frontiers, the influence of West Cameroon is practically nil. Therefore, unless the East Cameroon leader and intellectual, in whose hands cultural initiative lies, is prepared to share this authority with his brother from West of the Mungo, unless he is prepared to make the giant effort necessary to break loose from the strait-jacket of his French education, unless he will show proof of his intellectual probity and admit candidly that there are things

West Africa, 8 July 1967, p. 880, quoted by Le Vine 1971: 102.

6 For his career and ideas, see Lyonga 1989 and Monono 1991.

7 See Abbia, no. 5, (March) 1964. 
in the Anglo-Saxon way of life that can do this country good, there is little chance of survival, neither for English influence, nor even for African values in the Federal Republic of Cameroon.

With African culture moribund, with John Bullism weak and in danger of being smothered, we will all be French in two generations or three.

Fonlon stressed that cultural equality and equal participation would have to become the guiding principles of the federation if political integration was to be fully realised. To achieve cultural equality, he argued strenuously for genuine bilingualism in terms of a specific programme for the schools, which he considered to be the principal instrument for forming Cameroonian culture. He was especially anxious to see the newly created University of Yaoundé become a unique and serious experiment in bicultural and bilingual studies. Bilingualism for Fonlon was a means of preventing West Cameroonian values and cultures from being overwhelmed but it also stemmed from a sincere intellectual cosmopolitanism (Stark 1976). In September 1964, Fonlon organised a closed-door meeting of the top leaders of the ruling parties in the two states, Foncha's KNDP and Ahidjo's Union Camerounaise (UC). During this meeting, he expressed the KNDP's dissatisfaction with the inequality of treatment of the West Cameroon state in the federation, especially in the formulation of policy at the federal level, and the need for a constitutional review in order to restore some of the authority the states had lost to the federal government. Consequently, he demanded effective KNDP participation in the conception, elaboration and application of policy in every field of government in the form of regular consultations on government policy between the parties and an equal quota of cabinet ministers in the federal government. Fonlon was thus able to stir up West Cameroon regional feelings briefly in the mid-1960s but his efforts were frustrated by Ahidjo's growing power in the federation and divisions among the West Cameroon political elite itself. Ahidjo was quick to realise that by the antagonism that developed among them, the Anglophone leaders had become like toothless bulldogs. They could bark but in no way could they bite.

The party splits and political fighting in West Cameroon during the first years of the federation's existence would fill a small volume. It is important to emphasise here that the divisions among the West Cameroonian political elite were not based on any ideological differences. It was rather their persistent struggle for the seizure, consolidation and expansion of power within the new federal state that divided the Anglophone political elite and preventing them from forming a united front against Ahidjo's attempts to weaken the federal structure and undermine the autonomy and identity of West Cameroon. Their unbridled jockeying for positions of power intensified when they understood that the source of power was rapidly shifting from the Federated State of West Cameroon to the federal state. As Le Vine (1971: 96) pointed out, the years 
1962-1966 which were a prelude to the formation of a single national party, 'witnessed a complex political ballet in which the principal parties and politicians simultaneously strove to retain their influence in the West and manoeuvred to put themselves in the best possible position for the merger of all parties at the national level'.

Ahidjo was able to dominate the federation during the first years of its existence by playing off Anglophone political parties against each other and eventually persuading them to support the idea of a single national party. Only one month after reunification, in November 1961, Ahidjo first appealed for the formation of a single national party, which he rightly perceived as a major step to the realisation of his main objective: the creation of a highly centralised unitary state. Employing various strategies including intimidation, proscription, co-option and patronage, he succeeded by 1962 in transforming his UC party into the single party in East Cameroon. He then directed his attention to West Cameroon. The internal political developments in West Cameroon combined with his skilful use of federal constitutional powers and patronage ensured the outcome of political unification so desired by Ahidjo. At one time or another, all the parties in West Cameroon were for or against the idea of a single party, depending on whether to their own estimation, it increased or reduced their power and influence, and thereby their ability to bestow patronage (Johnson 1970: 280). The speed with which the West Cameroonian political elite, who had always championed a multi-party democracy, eventually embraced the single-party concept is clear evidence of their lust for power and influence within the changing power constellation in the federal state (cf. Kofele-Kale 1987).

Dr E.M.L. Endeley, the leader of the South West-based CPNC, was the first to be converted to Ahidjo's idea of a one-party state. For example, during Ahidjo's trips to West Cameroon in 1961 and 1962, Endeley expressed his party's willingness to support Ahidjo's vision of national unity and a centralised federation, including the formation of a single national party. Apparently, there were two main reasons for his swift support of a one-party state. First, as the leader of West Cameroon's minority party, Endeley saw Ahidjo's plans not only as an opportunity for him to play a role in national politics but also as a means of preventing domination of his party by the majority KNDP. In his opinion, minority parties were constantly harassed in independent African states and were forced to stifle their vieyss for fear of being accused of subversive activities against the government. Second, he and other party members

8 For example, Endeley himself was arrested on 10 October 1962 after he had given an exclusive interview to the Nigerian Daily Times entitled 'My Country is in a Bad State' but he was later released on bail with a surety of FCFA 69,200. See letter from 
saw South Westerners as a subordinate group in West Cameroon. They were therefore inclined to embrace the one-party state and saw it as a way for the South West to escape North West domination. They regularly accused the ruling North West-based KNDP of giving preferential treatment, at the expense of the South West, to the North West in terms of development. They also frequently alleged that the KNDP government tended to discriminate against South Westerners in appointments and promotions in the civil service and to arbitrarily dismiss them from their posts, particularly if they had any history of association with opposition party members, whether by political affiliation, friendship or even marriage. Due to these two factors, the CPNC became the principal advocate in West Cameroon of the idea of a one-party state (Rubin 1971: 150; Stark 1976: 435; Johnson 1970: 265-67, 276).

The fear that an Ahidjo-Endeley agreement could undermine his authority as prime minister of West Cameroon and leader of the KNDP prompted Foncha on 27 April 1962 to agree to an alliance between his party and Ahidjo's UC in the Federal Assembly and the formation of a National Coordinating Committee between his party and the UC. Among other things, the committee was designed to explore ways of merging the two parties into a single national party. But until that goal was achieved, the agreement called on both the KNDP and the UC to restrict their political activities to their own states. Such a restriction was important to both Ahidjo and Foncha because it removed the opportunity of an alliance by either man with any political parties or groups in either East or West Cameroon that might undermine their authority. However, the idea of uniting the two parties was not immediately popular in KNDP circles and many voiced their opposition when the KNDP met in Bamenda in June that same year.

A major factor that encouraged support for the one-party state was the internal struggle for power within the KNDP itself. A rift occurred within the KNDP when Foncha, who had retained the post of prime minister of West

J.N. Foncha, Prime Minister of West Cameroon, to the Minister Delegate to the Presidency, dated 3 October 1962, in BNA, File Vb/b (1962) 2, Dr E.M.L. Endeley.

9 Due to these perceived North West injustices against the South West, a South Westerner, Walter Wilson Mbong, started propagating a Victoria-Kumba-Mamfe Alliance (VIKUMA) to destroy North West domination over the South West and to establish a separate South West state in the federation, with or without the inclusion of related ethnic groups in East Cameroon. In 1965, he was jailed and his newspaper The Cameroon Spokesman was banned. See Ngwane 1994: 9 and The Cameroon Spokesman, 14 November 1964. It is noteworthy that A.N. Jua, Foncha's successor as prime minister of West Cameroon formed a coalition government between the KNDP and the CPNC in 1965. Endeley then became leader of government business, a position he had previously held during the British trusteeship period. See Mbile 2000: 196-98. 
Cameroon along with that of vice-president of the federal republic, was requested by the constitution to relinquish one of the offices by 1965. Foncha's decision to give up the post of prime minister of West Cameroon resulted in a contest for the vacated premiership, starting in 1963, between Augustine Ngom Jua and Solomon Tandeng Muna. Jua, who was the West Cameroon minister of finance at the time, enjoyed the support of the rank and file and had cultivated an image of being determined to brook no nonsense on matters of West Cameroon's interests in the federation. Muna, who was the federal minister of transport, works and telecommunications at the time, had the support of the party leadership because of his long administrative experience. He portrayed himself as being a federalist first and then a West Cameroonian. The victory eventually went to Jua. When Muna refused to accept defeat, he and his supporters were expelled from the KNDP. They quickly formed a party of their own called the Cameroon United Congress (CUC) 'with policies and initials aimed at reflecting Ahidjo's ideas and obtaining his favour' (Stark 1976: 435; Johnson 1970: 274). The CUC pledged support for the federal constitution but advocated the creation of a single political party and a unitary system for the whole country. Its popular slogan was 'one country, one government, one flag, one currency'.

The rivalry among West Cameroon political leaders provided an excellent opportunity for Ahidjo to call for the dissolution of West Cameroon's parties and the formation of a single national party. To most West Cameroonians, the idea of a single national party was abhorrent. The newspapers, especially the usually pro-government Cameroon Times, wrote editorials and carried letters from their readers denouncing the idea of a single party, which they felt would invariably lead to dictatorship (Johnson 1970: 264). Even some KNDP leaders came out strongly against the formation of a single national party. In early 1966, Fonlon (1966: 7-8) stated that:

Everywhere in Africa, people are being told that in order to speed up the economic and social development of the continent, the one party state has become a must. But almost everywhere where the system is being implemented, we witness the suppression of liberty, the elimination of debate, the imposition of silence and the use of despotism.

Afraid of being upstaged by members of the CUC and the CPNC who had expressed support for Ahidjo's call for a single party, even those leaders of the KNDP who had initially been opposed to the single party idea were forced to embrace the idea so as not to lose positions of power and influence in the federal state. On 11 June 1966, Ahidjo summoned the leaders of the three surviving West Cameroon political parties and the prime ministers of the two federated states to Yaoundé. He then reiterated that the multi-party system 
formed an obstacle to national unity and development, leading instead to strife, conflict and embitterment. He urged the party leaders to dissolve their parties. Within two days, each and every one of them consented and agreement was reached on the creation of a national party, to be called the Cameroon National Union (CNU) (Takougang \& Krieger 1998; Johnson 1970; Fonge 1997).

Once agreement on the creation of the CNU had been reached, Ahidjo moved fast to set the month of August 1966 as the deadline for the birth of the new party. Details of its framework were left to a steering committee whose composition reflected the dominant position of the eastern state's single party, which supplied 22 of the 30 committee members. The western state's parties combined were given only 8 members: four from the KNDP and two each from the CUC and the CPNC. The West Cameroon newspapers strongly protested against the lack of West Cameroonian influence in the CNU steering committee. They insisted that Fonlon be appointed Secretary-General of the Steering Committee. In addition, they alleged that the newly presented CNU constitution did not provide any safeguards for the preservation of the culture and institutions of the Anglophone minority, and they expressed their fear that the creation of a single national party in the federation would eventually lead to the creation of a unitary state Despite such criticisms, the CNU was launched on 1 September 1966. Ahidjo became its president and Foncha became one of its vice-presidents.

While the euphoric celebrations of the birth of the CNU were still reverberating, Ahidjo attempted to introduce one of his anti-federalist reforms. On 1 October 1966, the Kumba-based newspaper, The Mirror, published a story captioned 'Federal Regions May be Recarved'. The paper stated that Ahidjo planned to redivide the existing administrative divisions in such a way that the East Cameroon administrative divisions would cross the Mungo border and incorporate the West Cameroon administrative divisions. This information alarmed Anglophones who saw in such a measure a blatant attempt to submerge them and destroy the federal character of the country. Prime Minister Augustine Ngom Jua reacted swiftly and resolutely to this alarming news:

It must be emphasised that the Federal Republic of Cameroon is a federation of two states with different backgrounds, cultures and traditions; the present arrangement was in fact envisaged as the most ideal solution to reunification... Any exercise, therefore, that is designed to alter this arrangement ... will clearly alter the basis on which the entire Federation rests and will throw our present system of government into complete disarray ... It is equally clear that since ours is a democratic republic, a matter of far-reaching significance and consequences cannot be conceived and

10 See, for instance, The Cameroon Star, 1 August 1966, 5 August 1966, 13 August 1966 and 15 August 1966; The Cameroon Times, 6 August 1966; The Iroko, 6 August 1966. 
executed in secret without the full knowledge and concurrence of the people of West Cameroon through their accredited representatives, to wit, the West Cameroon Government.

Ahidjo's rejoinder was not long in coming. He did not deny the authenticity of the newspaper report but he did question what Jua meant by 'integration and absorption of one part of Cameroon by another part', stressing that there was a single Cameroon nation in which citizens had equal rights and duties. He asserted that:

The people of West Cameroon massively voted in favour of reunification; after reunification itself we freely consented that it was necessary to create a federation between the two states, and to create federal institutions. But that does not permit us to say there are two Cameroon nations.

The controversy that the 'recarving' of the Cameroon Federation generated clearly brought Jua into the limelight as a champion of West Cameroon identity, and demonstrated the difficulties of his coexistence with centralist Ahidjo. Jua was definitely not the type of collaborator Ahidjo could work with towards the realisation of his unitary schemes.

Following the establishment of a one-party state, Ahidjo started consolidating his hold on West Cameroon by giving positions of power to supporters of a strong centralised federal state among the Anglophone political elite. In 1968, Jua, a staunch advocate of the state's rights, was replaced by Muna as prime minister of West Cameroon. In 1970, Foncha, the West Cameroonian architect of the federation, was replaced as vice-president by Muna. On this occasion, Ahidjo had the constitution amended to allow Muna to accumulate the functions of federal vice-president and prime minister of West Cameroon. Foncha did not protest against his removal. Foncha was a simple, modest, honest and religious person who was too weak and naive to be able to challenge someone of Ahidjo's cunning and subtlety. ${ }^{13}$ After Foumban, he lost control

The Cameroon Times, 29 October 1966, p. 1.

Ibid.

13 In his unofficial biography of Foncha, Soh (1999) mentions two major blunders made by Foncha in the post-reunification period, seriously weakening his power position. First, his refusal in 1965 to run for the presidency, opting instead to run for the post of vice-president for the sake of peace and stability in the young nation. Foncha's decision was not pleasing to Ahidjo's political opponents in Francophone Cameroon. In fact, the opposition leaders in the southern part of Francophone Cameroon who had been victimised by Ahidjo and the Bamileke were hoping to throw their weight behind Foncha and remove Ahidjo from power. Second, his agreement in 1966 to fuse his KNDP party with Ahidjo's UC party led to the formation of the one-party state. By so doing, he made himself a political underling 
over developments in his former party, the KNDP, and in the federation. In late 1971, Fonlon, who was considered to be too independent, was dropped from Ahidjo's cabinet. Bilingualism, the cause he had fought for within the federation, was still official government policy but was symbolic only. Fonlon might have been dropped but his support and faith in Ahidjo's leadership qualities remained firm, even at the risk of straining his relations with Paul Biya when the latter became president in 1982, with Ahidjo staying on briefly as party leader.

With the changing power relations in the federation, the Anglophone political elite appeared to be more interested in seeking Ahidjo's patronage than in safeguarding West Cameroonian autonomy and identity. The Anglophone administrative elite, too, increasingly favoured the federalisation of state services, enticed by the higher salaries and better conditions in the federal services than in the state services (Fonge 1997). Given this situation, Ahidjo played his trump card. On 6 May 1972, he announced in the National Assembly that he intended to transform the federal republic into a unitary state provided the electorate supported the idea in a referendum that would be held on 20 May, thereby abrogating Clause 1 of Article 47 of the 1961 federal constitution, which read: 'Any proposal for the revision of the present constitution, which impairs the unity and integration of the Federation shall be inadmissible'. This important clause had been specifically inserted into the constitution to assure West Cameroonians that the federation could not be dissolved. Even if the constitution were to be amended, it should not be done by referendum because Clause 3 of Article 47 stipulated that 'proposals for revision shall be adopted by simple majority vote of the members of the Federal Assembly, provided that such majority includes a majority of the representatives of each of the Federated States'.

Ahidjo probably chose the use of a referendum to avoid any public debate about the new constitution and to secure an overwhelming turnout in its favour (Le Vine 1976: 276). The president's justification for what he referred to as a 'peaceful revolution' was that federalism was too costly an administrative system for a developing country and that it fostered regionalism and impeded economic development. Yet, there were still two other even more important reasons for his proposal. First, there was the discovery of oil in West Cameroon in 1967. And second, there was Ahidjo's persistent suspicion that the Anglophones might secede from the federation. This suspicion was given added weight by the outbreak of civil war in Nigeria in 1967 - a war provoked by secessionist tendencies among the Igbo with whom the West Cameroonians had

to Ahidjo, who could move him around as he liked. As long as Foncha's KNDP party existed, Ahidjo was afraid of it because it was a vast political organisation that could mobilise votes even East of the Mungo and throw him out of power. 
shared a common colonial administration. In sharp contrast to the Cameroonian federal government, the Anglophones tended to sympathise with the breakaway Eastern Region of Nigeria that had established itself as the independent Republic of Biafra. The Ahidjo government was afraid that should the secession of the Eastern Region of Nigeria succeed, the chain reaction of the domino theory could affect West Cameroon. Ahidjo's call for a unitary state thus aimed to contain any threat of secession by West Cameroon and to ensure that the petro-dollars would not escape his control.

The Ahidjo regime claimed massive popular support for the draft constitution during the referendum, and hence the immediate establishment of the United Republic of Cameroon. Given the growing disillusionment of the West Cameroonian population with the union between Anglophone and Francophone Cameroon as sketched above, the referendum results are more likely a manifestation of the regime's autocratic nature than of the West Cameroonian population's support. In other words, fear prevented West Cameroonians from expressing their objective interests. The ballot was far from secret, election results were arranged beforehand, and it was neither politically wise nor politically safe to hold and express views different from the president's, let alone oppose in words or deeds any of his plans or actions. Anecdotes to show that the referendum was completely stage-managed by party stalwarts abound. At the Cameroon College of Arts, Science and Technology in Bambili, for example, only 'yes' ballots were provided. When students refused to vote in the absence of 'no' ballots, the army was rushed in under the pretext of preempting any disruption of the voting process. Professor Kofele-Kale noted that 'there were Bakweri villages where people had all gone to their farms and thus did not vote, yet the returning officers turned in vote tallies of 99.9 per cent, suggesting that the results were cooked' The West Cameroon political elite, too, was well aware of the widespread opposition of the Anglophone population to the introduction of a unitary state but it lacked the courage to tell Ahidjo, for fear of losing pockets of power and privilege. In 1991, Solomon Tandeng Muna, who was at the time of the referendum prime minister of West Cameroon and vice-president of the federal republic, admitted in a radio interview that he had not dared to reveal to Ahidjo the true feelings of the Anglophones in the referendum because it would have been tantamount to signing his own death warrant (Boh \& Ofege 1991: 16).

14 See Ngoh 1992 and 1996. See also the interview with François Sengat Kuo, who confessed to have drafted the 1972 constitution, in Le Messager, 9 June 1992, p. 10.

15 The government claimed that 98.7 per cent of the country's 3,326,280 voters went to the polls, 99.9 per cent of them voting 'yes'. See Mbuagbaw et al. 1987: 133.

16 Cited in The Post, 7 June 2000, p. 3. 
The new cphstitution increased the already enormous powers in the hands of the president. It eliminated the office of the vice-president, of prime minister of West and East Cameroon together with the cabinets of the two states, the two legislatures and the West Cameroon House of Chiefs. Although the post of vice-president was abolished, Muna remained second in the hierarchical order in the unitary state, becoming speaker of the largely ceremonial National Assembly. To reduce any danger of united Anglophone action, Ahidjo decided a few months later to divide the erstwhile Federated State of West Cameroon into two provinces, the South West and North West Provinces, informed by the internal contradictions within the Anglophone community between the coastal/forest peoples (in the South West) and the Grassfields peoples (in the North West). Like the other five Francophone provinces, the two Anglophone provinces were headed by a governor appointed by the president and directly responsible to him through the minister of territorial administration.

\section{Anglophones and the one-party unitary state, 1972-1990}

There is no doubt that the vast majority of the Francophone elite welcomed the abolition of the federation. Like the Ahidjo government, it tended to perceive the massive approval of the unitary state in the 20 May 1972 referendum as the final triumph in the strive for national unity after reunification.

There is sufficient evidence that the Francophone elite was never in favour of federalism. Immediately after the February 1961 plebiscite in the then Southern Cameroons, influential Francophones, who were organised in the Cercle Culturel Camerounais led by Dr Bebey-Eyidi, made it known that 'federalism was not the best form of reunification'. Nonetheless, they were willing to admit that 'federalism was appropriate for the immediate situation since it would take time to harmonise the different cultures and habits of the two territories'. They went on to add that 'federalism should be fundamentally provisional, transitory and should lead, at the earliest possible time, to a unitary state'. Even the UPC, which was at that time fighting a guerrilla war against the Ahidjo government, supported the idea of a unitary state because 'only a unitary government can guarantee the security and unity of a reunified Cameroon' (Ngoh 1990: 199).

In sharp contrast to the Francophones, the vast majority of the articulate Anglophones tended to perceive the abolition of the federation as a major threat to the preservation of their cultural identity and the representation of their

17 The constitution of the United Republic of Cameroon is reproduced in Gonidec \& Breton 1976: 55-62. 
interests. For them, the unitary state was a clear expression of the hegemonic tendencies of the Francophone-dominated state and even of the Francophone population as a whole, which would invariably lead to a further 'marginalisation, exploitation and assimilation' of the Anglophone region. They soon started to resent their region's loss of autonomy and the perceived reality of the subordinate position of the Anglophone minority in the unitary state. Their numerous grievances were mainly of a political, economic and cultural nature.

In the political domain, Anglophones complain of Anglophone exclusion from the key government and party positions and of their inferior role in the decision-making councils and organs. Anglophones have never held ministerial posts in the most important and sensitive ministries, such as the Ministries of Defence, Foreign Affairs, Territorial Administration, and National Education. They are instead usually appointed to ministerial posts in ministries with a lower status, such as the Ministries of Transport and Mines, which thus have become stigmatised 'Anglophone ministries'. It is also rare to find an Anglophone director in the civil service. A general complaint among Anglophones is that they are assumed to be only fit to play 'deputy' or 'assistant' to Francophones, even when they have clearly superior expertise.

In the economic domain, Anglophones complain of the dismantlement or neglect of their region's infrastructure, the lack of public investment in their region, and the rape, drain and squander of their region's economic resources. They claim that their region has failed to benefit from its extensive oil resources that have enriched pillaging Francophones and made them even more arrogant. Oil resources are allegedly used by the Francophone-dominated state to feed 'the bellies' of its allies (Bayart 1989) and to stimulate economic development in Francophone regions. Anglophones strongly resent the fact that the Société Nationale de Raffinage (Sonara), the oil refinery near Victoria (Limbe), continues to be headed and predominantly staffed by Francophones who treat them condescendingly and with indifference.

In the cultural domain, Anglophones complain of the continuous attempts at 'Frenchification' or what Kofele-Kale (1987) has called 'the Gallicising of public life', that is the pre-eminence of French as the official language and of inherited French institutions and bureaucratic practices in all aspects of state administration and public life. They may have experienced little real contact with the primary vehicles of Anglo-Saxon cultural values during the colonial era but today Anglophones are united by a common frustration with the devaluation and exclusion of whatever they have come to imagine as constitutive of an Anglo-Saxon way of life.

18 For the multitude of Anglophone complaints, see, for instance, Mukong 1990 and All Anglophone Conference 1993. 
Anglophone complaints about the 'Gallicising' of state and public life are not without merit. By a five to one ratio, the complaints reflect the demographic balance between the official language communities and the fact that the harmonisation of inherited political and administrative systems was bound to favour the senior (Francophone) partner of the union (Eyoh 1998a: 262). More problematic are the claims of systematic political and economic discrimination. Most analysts of Cameroonian politics agree on the effective integration of Anglophone elites into the hegemonic alliance (cf. Bayart 1979; Ngayap 1983; Kofele-Kale 1987). The conclusion or inference of much of this analysis is that these complaints are self serving. In treating Francophones as a homogeneous group, Anglophone elites suppress the fact that the grievances they seek to particularise are shared by other sub-national groups. It is worth noting, as the Anglophone economist Wilfred Ndongko (1980) has ably demonstrated, that the problem of economic deprivation in Anglophone Cameroon is not unique to the region. Summarising the most pertinent economic data, he shows that two Francophone regions, the North and the East, join Anglophone Cameroon in forming a triad of the most economically underdeveloped regions in the country. This is not to suggest that Anglophone complaints about the relative backwardness of their region should be brushed aside, especially when we take into account the fact that this region is the nation's breadbasket and the source of its considerable oil wealth. We only wish to signal that this problem cannot be explained in isolation but can be better understood when viewed within the context of inequalities among and within the regions in the country, not in Manichean terms as a distinction between a developed Francophone and an underdeveloped Anglophone Cameroon (Kofele-Kale 1987: 65-67).

A number of factors, notably severe repression, an elaborate system of ethno-regional patronage by the regime (Jua 1991), and fierce competition between the North West and South West elites for power positions in the unitary state, largely precluded the Anglophone elite from openly expressing criticism of Francophone domination during Ahidjo's presidency of the oneparty unitary state. Fonlon again appears to have been one of the few members of the Anglophone elite who dared to raise the 'Anglophone problem' in this period. In 1980, he wrote a letter to Ahidjo in which he described Anglophone feelings as follows:

There is a deep feeling of apprehension amongst the Anglophones. This fear is because after almost 18 years of unification, they still have the impression of being kept away from certain aspects of national life. Some Cameroonians do not hide it from them that they are regarded as second-class citizens. Hence, the generally held

19 For more recent economic data on Anglophone and Francophone Cameroon, see, among others, Konings 1993, 1997 and 1998; Van de Walle 1993; Mama 1996. 
view (which for some has become a firm conviction) that Anglophones can be in the best of cases only assistants, in no matter which ministry.

If the Anglophones who are so placed under Francophones were less qualified or less experienced than the latter, this situation could easily have been understood. But this is not always the case. Mr President you will thus understand why I have spoken of a deep feeling of frustration amongst the Anglophones (Collectif 'Changer le Cameroun' 1992: 265-66; our translation).

Anglophone expectations were raised when Prime Minister Paul Biya succeeded Ahidjo as president on 6 November 1982. Initially, there were some hopeful signs that the new president might end Anglophone marginalisation and their second-class status in the unitary state. In his maiden visit to the Anglophone region Biya tried to dispel the deep-seated feelings of apprehension amongst Anglophones. He addressed them in English. This was actually the first time the Anglophone population had heard their president address them in English. On this occasion, Biya raised issues that were close to the hearts of Anglophones, including the large degree of centralisation in the unitary state and the lack of infrastructural facilities in the Anglophone region. He then promised to tackle these issues immediately. Nothing more, however, was heard about them after he had returned to Yaoundé. If anything, he soon would be accused of making matters worse for Anglophones. His early honeymoon with the English language would die a natural death, as Biya would stubbornly insist on speaking French not only to his Anglophone collaborators but even to visiting English-speaking foreign dignitaries.

Even more significantly, in his inaugural speech Biya proposed a 'New Deal' to the Cameroonian people. Its main policy guidelines were to be 'rigour and moralisation' and 'national integration'. These guidelines were intended to bring about a state characterised by the judicious and stringent management of public affairs, transparency and public accountability by government officials as well as total absence of ethno-regional particularism and favouritism (Biya 1987; Takougang \& Krieger 1998). However, as Anglophones soon came to realise, these professed policies were mere slogans, probably used by Biya to extricate himself from Ahidjo's shadow (Konings 1996a: 250). Corruption and mismanagement in public life rapidly reached unprecedented levels. It was, therefore, not surprising that Anglophones were inclined to attribute the severe economic crisis that affected Cameroon from the mid-1980s first and foremost to the corruption and mismanagement of the Biya regime (Jua 1991; Konings 1996a). During the economic crisis and subsequent structural adjustment programme one could observe a mounting anxiety in Anglophone Cameroon that its major agro-industrial enterprises, particularly the Cameroon Develop-

20 For a detailed discussion of the position of Anglophones during the Biya regime, see Konings \& Nyamnjoh 2002. 
ment Corporation (CDC) and Plantations Pamol du Cameroun Ltd (Pamol), would be either liquidated or sold to Francophone or French interests (Konings 1996b, 1997). National integration soon turned out to be an ideological justification for effacing and assimilating the Anglophone cultural legacy. What fuelled Anglophone frustration was that, in spite of its promise to create a society where national concerns transcended ethno-regional interests, the Biya regime instead encouraged ethno-regional favouritism. Especially after the failed military coup in 1984, it became manifest that there was an increasing monopoly of key posts by members of President Biya's ethnic group, which is loosely classified as Beti. As of August 1991, according to Takougang \& Krieger (1998: 94-95), 37 of the 47 senior prefects were Beti, as were threequarters of the directors and general managers of the parastatals, and 22 of the 38 high-ranking bureaucrats who had been appointed in the newly created Office of the Prime Minister. Such a lion's share of positions by Francophones of Beti origin meant that even fewer positions were available to Anglophones. One of the most belittling experiences for them was to have Francophone prefects and governors speak to them through interpreters, all in the name of national unity.

In the wake of the limited degree of liberalisation that Biya introduced after assuming power in November 1982, Anglophones began voicing their longstanding grievances. In September 1983 the minister of national education promulgated an order modifying the Anglophone General Certificate of Education (GCE) examination by making it similar to the Baccalauréat. Apparently, the order was intended to facilitate the entry of Anglophone students into the professional and technical institutes in Cameroon, which were exclusively based on the French system. Anglophone students, however, interpreted the proposed reform as a subtle attempt by the Francophone-dominated state to assimilate the Anglophone educational system. They maintained that the problem of Anglophone exclusion from the professional and technical institutes in the country could not be resolved by assimilation but rather by the creation of institutes based on the English system. Ensuing demonstrations and the boycotting of classes by Anglophone students at the University of Yaoundé and in the Anglophone urban centres met with extreme police brutality (Nyamnjoh 1996a). English-speaking students at the University of Yaoundé used this protest action to voice some of their other grievances, including the dismissal of Dr Bisong, an Anglophone lecturer in the Faculty of Law and Economics, who offered one of the few courses in English in the officially bilingual university. In a petition addressed to the minister of national education, they took up the issue as follows: 
With regard to the University of Yaoundé, we strongly condemn the discrimination in the teaching languages as glaringly exemplified by the ignominious suppression of the courses offered in English by Dr Bisong (Accounting - 2nd Year; and Cost Accounting and Budgetary Control - 3rd Year, Economics Department) for the sole reason that such courses were offered in English. The Francophone students of the department had protested to the Chancellor of the university that such important courses could not be delivered in English. Immediately Dr Bisong was accused of inefficient delivery of his lessons and they were handed over to a Francophone lecturer. The inefficiency was surely the use of the wrong language and not the substance of academic stuff delivered.

The situation did not calm down until 11 days later when President Biya issued a statement calling on all students to return to classes and announcing the setting up of a commission of highly qualified and experienced Anglophones and Francophones to look into the students' grievances.

Even Solomon Tandeng Muna, the then speaker of the National Assembly and constitutionally second-in-command in the unitary state, highlighted the failure of national integration in a memorandum entitled 'Some Points of Social Justice' which he addressed to the head of state in January 1984. It is worth recalling that Muna used to be prime minister of West Cameroon and vicepresident of the Federal Republic of Cameroon, and that he had closely collaborated with Ahidjo in dismantling the federal institutions. In his memorandum, he appeared to identify with the general Anglophone feeling of frustration regarding their second-class citizenship:

Virtually every Anglo-Saxon qualification is inferior to French ones, and so AngloSaxon standards are supposed to be inferior to French ones. This gives an idea of the frustrations which English-speaking citizens face virtually at all levels in the university, in the public service and in state corporations with regard to their progress. ${ }^{2}$

Indeed, for a long time, Anglo-Saxon certificates and diplomas, held mainly by Anglophones, were grossly undervalued and belittled by the Francophone leaders and elite. Consequently, Anglophones entered the public service at points far below those of Francophones with equivalent qualifications. At the University of Yaoundé in particular, this situation hindered and delayed the promotion of Anglophone lecturers to higher positions. Anglophone complaints were ignored for a long time. It was not until the tail end of the Ahidjo administration that a petition by $\mathrm{PhD}$ holders teaching at the University of

21 Petition of English-speaking students, University of Yaoundé, to the Minister of National Education, dated 19 November 1983, reproduced in Mukong 1990: 26.

22 Some Points of Social Justice. Memorandum addressed by Honourable Solomon Tandeng Muna, Speaker of the National Assembly, to the Head of State, Yaoundé, dated January 1984, reproduced in Mukong 1990: 27. 
Yaoundé addressed to the government and some foreign embassies yielded a positive response. As a result, the notion of 'terminal degree', which virtually puts a $\mathrm{PhD}$ on a par with a Doctorat d'État, came into vogue. Nevertheless, Francophones often continued to regard Anglo-Saxon certificates and diplomas as being inferior to French ones allegedly because it took relatively fewer years to obtain them than was possible with their French equivalents (Chem-Langhëë 1997: 93).

One month later, in February 1984, President Biya, without warning or consultation, changed the official name of the country from the United Republic of Cameroon to simply the Republic of Cameroon - despite vehement Anglophone protests that this was the name of independent Francophone Cameroon prior to reunification. The new name appeared to deny that the Cameroonian state was composed of two distinct entities. Biya argued that the name change was not only a demonstration of the political maturity of the Cameroonian people after almost twenty-five years of independence but also a sign that the people had finally overcome divisions caused by seventy years of European colonisation (Biya 1987: 6). In Anglophone circles, however, Biya's unilateral name change seems to have given rise to two different interpretations.

Some Anglophones consider this action as the boldest step yet taken toward their assimilation and disappearance as a distinct founding community. For them, the new name was clear evidence that, as far as Biya was concerned, the Anglophone territory and its people had lost their identity and had become an indistinguishable part of the former Republic of Cameroon, thus carrying to its intended conclusion Ahidjo's designs of absorbing and assimilating the Anglophone minority into the Francophone-dominated state.

Other Anglophones argued that, by this action, La République du Cameroun had unilaterally seceded from the union and thus lacked a constitutional base from which to continue ruling the former Southern Cameroons. They are often inclined to appeal to the United Nations to assist its former Trust Territory in peacefully separating from La République. This view was first expressed by the eminent Anglophone lawyer and first president of the Cameroon Bar Association, Fon Gorji Dinka. On 20 March 1985, Dinka addressed a memorandum to Paul Biya entitled 'The New Social Order'. In it, he declared the Biya government unconstitutional and called for the Southern

23 Reference to the incumbent regime as the government of La République du Cameroun, the name adopted by Francophone Cameroon at independence, has become a key signifier in the replotting of the nation's constitutional history as a progressive consolidation of the recolonisation of Anglophone Cameroon by the post-colonial Francophone-dominated state. See Eyoh 1998a: 264. 
Cameroons to become independent and to be rebaptised as the Republic of Ambazonia:

[On 4 February 1984] Comrade Biya promulgated law no. 84-001 abolishing the United Republic of Cameroon whose President he was. Again either by design or by default the law failed to include a clause stating that the institutions of United Republic of Cameroon were to be retained as institutions of the newly revived Republic of Cameroon. So the law abolished all the institutions of the Republic of Cameroon with it. Since the revived Republic of Cameroon has not yet set up its own institutions, it has neither a government nor a legislature nor any other institutions of administration. So Comrade Paul Biya is neither President of the United Republic of Cameroon, which has been abolished, nor of the newly revived Republic of Cameroon.

We now come to the sad end of the story. By reviving the old Republic of Cameroon, which the Foumban Accord had submerged in order to create a Federation with Southern Cameroon-on-Ambas, the Republic of Cameroon has irretrievably seceded from the union.

So unless a new accord is included so as to create a basis for a union between the two states, any claim, by the Republic of Cameroon to govern Southern Cameroonon-Ambas, would simply mean annexation pure and simple.

Dinka was arrested and imprisoned without trial until January 1986, earning him the status of martyr for the Anglophone cause.

The Bamenda congress of the ruling party in 1985 not only changed the name of the ruling party from the Cameroon National Union (CNU) to the Cameroon People's Democratic Movement (CPDM) but was also the forum of unprecedented debate compared with previous party congresses. However, this new relative freedom of expression led to the unmasking of themes less welcome to the regime. Two memoranda submitted to the congress by Anglophone elite groups resident in Douala expressed Anglophone resentment about their region's loss of autonomy and illustrated with a multitude of examples the recolonisation of their region by the Francophone-dominated state:

Once more we respectfully seize this opportunity to draw your attention to our memorandum ... concerning the humiliating and revolting colonial status that is gradually but systematically being imposed on the English-speaking Cameroonians by the administration...

24 This name is derived from Ambas Bay at the foot of Mount Cameroon. This was the first area of permanent British settlement in the present Anglophone region. In 1858, the British Baptist missionary, Alfred Saker, purchased land from the King of Bimbia, becoming de facto governor of the little colony of Victoria named after the British queen. See Ardener 1968.

25 'The New Social Order' by Fon Gorji Dinka, 20 March 1985, reproduced in Mukong 1990: 98-99. 
We have over the years watched with increasing alarm the various unilateral manipulations of the constitution to the extent that the English-speaking region of Cameroon is now being treated by the administration either as a conquered country or as a buffer zone, and its citizens as foreigners.

Because of this colonial status which has been imposed on us both dictatorially and through political chicanery, we now find ourselves almost completely stripped of that cherished British cultural heritage to which some of us were born and nurtured. ${ }^{\text {E. }}$

In the period 1985-1990, however, the number of Ang-ophone petitions and memoranda addressed to government and party declined. This was undoubtedly due to the fact that the Biya government was stepping up repression in this period because of the deteriorating economic and political crisis in the country (Takougang \& Krieger 1998). With the introduction of multipartyism in late 1990, Anglophones started openly to organise for the defence of their interests.

\section{Conclusion}

This chapter has highlighted the various strategies used by the Ahidjo regime to abolish the federation and replace it with a one-party unitary state in 1972. These moves affirmed the original intent of the Francophone elite - to destroy the autonomy and identity of West Cameroon. Their design came to a logical conclusion in 1984 when Ahidjo's successor, Paul Biya, renamed the country, changing its name from the United Republic of Cameroon to the Republic of Cameroon. For the Anglophones, this change of name was a clear indication that the Francophone elite simply denied the fact that the Cameroon state was made up of two distinct entities, thus suggesting that either the Anglophone territory had been assimilated and absorbed by the former Republic of Cameroon or that the former Republic of Cameroon had unilaterally seceded from the union.

The hegemonic and assimilative tendencies of the Francophone-dominated state were strongly resented by the majority of the Anglophone population, leading to the development of an Anglophone consciousness with the feeling that their territory with a distinct colonial legacy was being subjected to marginalisation, exploitation and assimilation by the Francophone-dominated state and even by the Francophone population as a whole. But we have also pointed out that the Anglophone political elite bears an important share of

26 Memorandum presented to the Head of State and Chairman of the Cameroon People's Democratic Movement by a Joint Committee of the Elite of the North West and South West Provinces Resident in Littoral Province, reproduced in Mukong 1990: 63-64.

27 For the Anglophone petitions and memoranda during this period, see Mukong 1990. 
responsibility for the Anglophone predicament. Generally speaking, they did not resist the abolition of the federation, which they had initially embraced as the embodiment of the highest ideals of reunification. Apparently, as soon as they came to realise that their influence within the Federated State of West Cameroon had begun to be whittled down, the federal arrangements no longer suited their designs. They started competing for Ahidjo's favours, aspiring to positions of power and privilege within first the single party and the federal government and eventually within the unitary state, blatantly neglecting the defence of West Cameroonian autonomy and interests. The co-opting of the Anglophone political elite into the 'hegemonic alliance' (Bayart 1979) and the autocratic nature of the Ahidjo regime largely explain why Anglophones failed to protest openly against Francophone domination and recolonisation until the limited liberalisation introduced by Biya after succeeding Ahidjo as president in 1982. 


\title{
Anglophone struggles for a return to the federal state or for secession during political liberalisation, 1990-2002
}

\begin{abstract}
Anglophones have not only played a leading role in the accomplishment of political liberalisation in Cameroon, they have also used the liberalisation of political space to create or reactivate several organisations for the representation and defence of their interests. In this chapter we show that these Anglophone organisations soon came to form a major challenge to the Francophonedominated unitary state, insisting that the government should place federalism on the constitutional reform agenda. Confronted with the government's persistent refusal to enter into negotiations about a return to the federal state, they gradually adopted an even more radical stand, striving for secession and independence of the Anglophone territory.

In their pursuit of self-determination or autonomy, in the form of either a return to the federal state or outright secession, the Anglophone organisations have tried to muster the support of the international community and the Anglophone population. They have engaged in both a diplomatic offensive, regularly sending missions to relevant embassies, states and international organisations, and a 'sensitisation campaign' to inform the Anglophone population about their objectives and strategies and to mobilise it for action against the Francophonedominated unitary state. They enjoyed growing popularity in the Anglophone
\end{abstract}


territory in the period 1992-1996, having scored some successes in their struggle for autonomy. While the Anglophone movements for various reasons lost their initial momentum from 1996 onwards, the unexpected proclamation of the independence of the Anglophone territory on 30 December 1999 appears to have provided a new impetus to the Anglophone struggle.

\section{The growth of Anglophone organisations}

Given the Anglophone frustration with the Francophone-dominated state, it is not surprising that the first opposition party in the country emerged in Anglophone Cameroon. In 1990 the Social Democratic Front (SDF) was formed in Bamenda, the capital of North West Province, demanding liberalisation of the political space and capitalising on popular frustration among Anglophones following three decades of marginalisation. Its chairman was John Fru Ndi who was to enjoy widespread popularity among the urban masses because of his courage and populist style of leadership (Gwellem 1996; Takougang \& Krieger 1998; Konings 2001a). After the massive rally to launch the SDF on 26 May 1990 ended in the deaths of six young Anglophones, the state-controlled media tried to deny government responsibility for this bloody event and to distort the true facts (Nyamnjoh 1996b: 26-27). Anglophone students at the University of Yaoundé who demonstrated the same day in support of the SDF and political liberalisation were falsely accused by the regime of having marched in favour of the re-integration of Anglophone Cameroon into Nigeria and having sung the Nigerian national anthem and raised the Nigerian flag (Konings 2002). Leading members of the CPDM strongly condemned the Anglophones for this 'treacherous action' and what they considered as the premature birth of multipartyism in the post-colonial state. Their reaction to these peaceful demonstrations shocked many in the country. Anglophone Cameroonians were termed 'Biafrans', referred to as 'enemies in the house', and asked by the then Minister of Territorial Administration, Ibrahim Mbombo Njoya, 'to go elsewhere' if they were dissatisfied with 'national unity'. Indignant at his own party's behaviour, Foncha, the Anglophone architect of the federal state, resigned as first vice-president of the CPDM in June 1990. As Foncha explained:

The Anglophone Cameroonians whom I brought into the union have been ridiculed and referred to as 'les Biafrais', 'les ennemies dans la maison', 'les traitres' etc., and the constitutional provisions which protected this Anglophone minority have been 
suppressed, their voice drowned while the rule of the gun replaced the dialogue which the Anglophones cherish very much.'

There is general agreement that the launching of the SDF was a decisive factor in changing the political landscape in Cameroon. Under considerable internal and external pressure (Konings 1996a), the Biya government introduced a larger measure of political liberalisation. In December 1990 it announced the advent of multipartyism as well as a certain degree of freedom of mass communication and association, including the right to hold public meetings and demonstrations. ${ }^{2}$ As a result, several political parties, pressure groups and private newspapers were established in Anglophone Cameroon and began to express and represent Anglophone interests (Nyamnjoh 1996b: 38-49).

Subsequently, the SDF spread its influence to the South West Province and soon became the major opposition party in Anglophone Cameroon, and among Anglophones in the diaspora at home and abroad. Nevertheless, informed by not so distant experiences of perceived domination by Grassfielders, the South West elite continued to be suspicious of the aspirations of the SDF leaders for fear of renewed North West domination. With the exception of the Liberal Democratic Alliance (LDA), which has attempted with only limited success to become a serious political formation, the South West has failed to produce a strong and credible party mainly because of personal animosities. Indeed, the subsequent leadership struggle in the LDA between Mola Njoh Litumbe and Lydia Belle Effimba is but a further indication that the elite in the South West has yet to come up with an effective alternative to the SDF. ${ }^{3}$

The leaders of the SDF helped to turn the Anglophone region into a veritable hotbed of rebellion, leading to several fierce confrontations with the regime in power, especially during the 1991-1992 ghost-town campaign, which was essentially a prolonged demonstration of civil disobedience organised by the SDF and the allied opposition parties to force the Biya government to hold a sovereign national conference. ${ }^{4}$ The impact of this on the Anglophone community was particularly visible during the ensuing presidential elections when Fru Ndi received 86.3 and 51.6 per cent respectively of the votes cast in the North

1 John Ngu Foncha's letter of resignation from the CPDM is reproduced in Mukong 1990: 155 .

2 See Société de Presse et d'Editions du Cameroun (1991), Cameroon. Rights and Freedoms: Collection of Recent Texts, Yaoundé: Sopecam.

3 For reports on the leadership struggle in the LDA, see Cameroon Post, 16-22 April 1996 and The Rambler, 30 April-6 May 1996.

4 This was the period from April 1991 to January 1992 when the radical opposition issued calls, ultimatums, tracts, etc., asking the public to immobilise the economy by staying indoors, blocking streets, refusing to pay taxes and bills, and boycotting markets and offices. See Monga 1992; Mbu 1993. 
West and South West Provinces. It is hardly surprising that Biya's declared victory in October 1992 was a traumatic experience in Anglophone Cameroon, with violent protests against his 'theft of Fru Ndi's victory' throughout the North West. The president then imposed a state of emergency on the province for three months and Fru Ndi was kept under surveillance in his house in Bamenda. ${ }^{5}$ Whereas the United States, Germany, and the European Union denounced the fraudulent elections and the state of emergency in the North West and threatened to abandon their aid programmes to Cameroon until 'there was a clear advancement in the democratic process', the French continued to support Biya who appeared to be willing to safeguard their interests in Cameroon (Konings 1996a).

Paradoxically, although the SDF and Fru Ndi contributed immensely to Anglophone consciousness and action, the party increasingly presented itself as a national rather than an Anglophone party. It tried to deny persistent government charges that it was championing regional rather than national interests, and to attract a Francophone membership. The party actually proved to be so successful in its recruitment efforts in Francophone Cameroon, notably in the neighbouring West and Littoral Provinces, that Francophones soon outnumbered Anglophones in the originally Anglophone party. Most of the party's approximately 60 per cent Francophone membership is Bamileke, who are closely related to ethnic groups in the North West Province (Dongmo 1981; Warnier 1993; Tabapssi 1999). The Bamileke are inclined to see the SDF as a springboard to political power.

Increasingly presenting itself as a national party, the SDF tended to adopt a rather ambivalent attitude towards calls from newly emerging Anglophone pressure groups for a return to the federal state (see below). The leadership tried to avoid alienating either the Anglophone or Francophone members of the party but this was not an easy task. Anglophone members tended to be simultaneously supporters of the Anglophone pressure groups and were therefore inclined to bring pressures to bear upon the leadership to insert federalism in the party programme. Such pressure was usually opposed by the party's Francophone members who, like other Francophones, tended to adhere to the preservation of the unitary state, often equating federalism with secession. Given this situation,

5 For a government account of the violence that took place after the presidential elections, see Cameroon Tribune, 26 and 29 October 1992, and the Ministry of Communication's white paper on 'Human Rights in Cameroon', published in November 1993. For a detailed alternative account, see Boh Herbert, Cameroon: State of Human Rights Violations following October 11 Presidential Elections, Bamenda, 10 November 1992. The US Department of State's Country Reports on Human Rights Practices for 1992, Washington, DC, February 1993, pp. 31-40 is also relevant. 
the party leadership, dominated by Anglophones, was eager to reach a compromise between the two conflicting groups (see Chapter 6).

Since the SDF adopted a half-hearted stand towards the Anglophone problem, Anglophone interests came to be first and foremost represented and defended by associations and pressure groups which were created or reactivated by the Anglophone elite upon the introduction of political liberalisation in 1990. Some, notably the Free West Cameroon Movement (FWCM) ${ }^{6}$ and the Ambazonian Movement (AM) of Fon Gorji Dinka (see Chapter 3), advanced the liberation of the former West Cameroon state from annexation by La République du Cameroun and the creation of an independent West Cameroon or Ambazonian state, but most initially championed a return to the federal state, especially the Cameroon Anglophone Movement (CAM). ${ }^{7}$ CAM became by far the most important Anglophone pressure group. It is the only all-Anglophone association operating legally in the country, having been registered as a sociocultural, non-partisan association under law no. 90/053 of 19 December 1990. Its roots can be traced back to the South West-North West Elites Association in Douala, which in 1985 submitted memoranda to the Biya regime about the Anglophone predicament (see Chapter 3). Following the introduction of a larger measure of political liberalisation in December 1990, this association revamped its activities and changed its name to CAM in response to its expansion outside Douala. Several new branches and chapters were established in the country. On 4 July 1992 CAM held its first conference at Buea, the former capital of Southern and West Cameroon. On that occasion, its first chairman, Dr H.N.O. Enonchong, a prominent Anglophone lawyer in Douala, was forced to resign, having been accused of using the organisation for the advancement of his own political career. A new executive was elected headed by (retired) Ambassador Martin Epie (chairman), Dr Arnold Yongbang (vice-chairman) and Albert Mukong (secretary-general). ${ }^{8}$

Besides these associations aimed at representing broad-based Anglophone interests, a large number of other associations emerged hoping to represent more specific Anglophone interests. These included the Teachers' Association of Cameroon (TAC), the Confederation of Anglophone Parents-Teachers Association of Cameroon (CAPTAC), the Cameroon Anglophone Students' Association (CANSA), the Anglophone Common Law Association, the

6 See Free West Cameroon Movement (1991), The Restoration of the State of West Cameroon: The Final Solution to the Anglophone Cameroon Question, Bamenda/Victoria: WCJ.

7 CAM was later renamed the Southern Cameroons Restoration Movement (SCARM).

8 See Cameroon Post, 11-18 February 1992, p. 9; and Le Messager, 12 July 1992, pp. 2 and 8. 
Association of Anglophone Journalists, the Cameroon Anglophone Public Servants' Union (CAPSU), the Anglophone Youth Council, and the Anglophone Women's League. Some of these associations scored significant successes in their struggle against the Francophone-dominated state and its subsidiaries. For example, the TAC and the CAPTAC acting together with Anglophone churches and the media forced the government in 1993 to create a General Certificate of Education (GCE) Board. This signified an important victory for the Anglophones in their ten-year struggle against determined government efforts to destroy the GCE (see Chapter 7).

Anglophone associations and pressure groups, in particular CAM, have regularly been engaged in various forms of protest actions including strikes, boycotts and demonstrations against the Francophone-dominated state. The participation of various strata of the population demonstrates that the Anglophone problem is no longer perceived as solely an elitist concern. And how could it be so when marginalisation by the Francophone-dominated state has not been exclusively targeted at the Anglophone elite? Interestingly, these actions are partly directed against the myths and symbols of the unitary state. Anglophone movements have boycotted the celebration of the National Day on 20 May, the 'Day of the 1972 Glorious Revolution', declaring it a 'Day of Mourning' and a 'Day of Shame'. ' They have instead called upon Anglophones to celebrate the 'Day of Independence' on 1 October and the 'Day of the Plebiscite' on 11 February. On these feast days, the 1992-3 attempts by CAM activists to hoist the federation flag were reportedly answered by the security forces with 'extreme brutality'. ${ }^{10}$

Significantly, Anglophone associations and pressure groups increasingly referred to the Anglophone territory as the Southern Cameroons. Their leaders alleged (i) that the proper procedures for the enactment and amendment of the federal constitution had not been followed by Ahidjo (see Chapter 2); and (ii) that Francophone Cameroon had seceded from the union in 1984 when the Biya government unilaterally changed the country's name from the United Republic of Cameroon to the Republic of Cameroon - the name of independent Francophone Cameroon prior to reunification (see Chapter 3). From this perspective, they often claimed that the Trust Territory of Southern Cameroons had either never really ceased to exist or had been revived." ${ }^{11}$ The flag of the United Nations has therefore often been raised during Anglophone rallies to demon-

\footnotetext{
Cameroon Post, 19-26 May 1994.

10 Cameroon Post, 29 January-4 February 1992, 9 February 1993 and 6-13 October 1993.

11 For a Francophone critique on this Anglophone position, see Olinga 1994.
} 
strate the Anglophones' sustained belief in continued United Nations responsibility for the Southern Cameroons. ${ }^{12}$

Although the provocative reintroduction of this terminology has had the advantage of reminding inhabitants about the spatial and historical foundations of their Anglophone identity, Sindjoun (1995) observed that an Anglophone identity can only be claimed by inhabitants belonging to one of the territory's autochthonous ethnic groups - a distinction which tends to exclude even second- and third-generation Francophone immigrants from Southern Cameroonian citizenship. Hence the references made to the imagined 'Eleventh Province' for those who are seen and treated as 'Francophones of Anglophone culture'.$^{13}$ It should, however, be added that the Anglophone leadership has since tried to bridge the gap between 'pure' Southern Cameroonians and 'eleventh-province' members. Eleventh-province members who have shown a real commitment to the Anglophone cause have been invited to attend Anglophone conferences and have been given leadership positions within Anglophone organisations. The 1994 Bamenda Proclamation (see below) even 'declared that the notion of Eleventh Province is inconsistent with the restoration of the autonomy of Anglophone Cameroon and the governance of society within a distinct entity of Anglophone Cameroon and affirmed the necessity of all Anglophones to behave, act and be treated as sons and daughters of provinces comprised within the territory of Anglophone Cameroon'. Among Anglophone students and elites in the diaspora (North America, Europe and elsewhere in Africa), such distinctions have simply been dismissed as diversionary, and the tendency has been to emphasise a common culture and history over territorial boundedness.

\section{Anglophone struggles for constitutional reform}

A major Anglophone challenge to the Francophone-dominated state occurred in the wake of the Tripartite Conference convened by President Biya from 30

12 See 'Anglophone Independence: SCNC Adopts UN Flag, Calls for Quebec-Style referendum', in The Herald, 6-8 May 1996.

13 Indeed, in June 1995, the national radio carried an announcement on the creation of 'une association des Francophones de culture Anglophone'. Everybody knows that there are only ten provinces in Cameroon. By adopting the name of 'Eleventh Province', these immigrants express their marginalisation, being recognised neither as Francophone nor as Anglophone citizens. For a discussion on the 'eleventh province' association, see Geschiere \& Gugler 1998: 313-14; and Geschiere \& Nyamnjoh 2000. For the relationship between Anglophone identity and autochthony, see Konings \& Nyamnjoh 2000. 
October to 18 November 1991 to try to solve the severe political and economic crisis caused by the radical opposition's protracted ghost-town campaign (see above). The conference was attended by representatives of government, opposition parties and civil society. Although it was largely controlled by the government (Takougang \& Krieger 1998; Eboussi Boulaga 1997a), the nongovernmental representatives nevertheless succeeded in forcing constitutional reforms onto the agenda. During subsequent deliberations there was a clear divide between Anglophones and Francophones about the institutional configuration of a reformed state. Contrary to the majority of Francophone participants, who proposed some measure of decentralisation within a unitary state, Anglophone participants advocated the dismantling of the unitary state and the return to a federal state. The conference established a technical committee on constitutional matters consisting of seven Francophones and four Anglophones to determine the outlines of a new constitution. The committee was to be chaired by Professor Joseph Owona who at the time was secretary-general at the presidency and had an impressive track record of service in the unitary government.

The four Anglophone committee members belonged to different sociopolitical backgrounds. Mr Benjamin Itoe was then a minister and a CPDM militant; Dr Simon Munzu was a member of the CPDM (he later left the party to become secretary-general of the Buea-based LDA); Barrister Sam Ekontang Elad was an executive member of the LDA; and Dr Carlson Anyangwe had been nominated as an independent candidate even though it was soon to be revealed that he was a founding father of the SDF. The first three came from the South West Province, Carlson Anyangwe being the only North Westerner in the group. What united them was their Anglophoneness and their shared grievances about Francophone hegemony (which they could articulate both in French and English). They presented a draft proposal on a new federal structure that has come to be known as the EMIA Document (an acronym for Elad, Munzu, Itoe and Anyangwe). Itoe did not sign the document, ostensibly in a bid to keep his ministerial post, but it was not long, however, before he was sacked from the cabinet. The committee was suspended - without ever having met - on 14 February 1992 because of the upcoming parliamentary elections scheduled for March. However on 17 May 1993 its chairman, Professor Owona, presented a draft constitution to the Anglophone Prime Minister Simon Achidi Achu, which preserved the essential features of the unitary state, making no concession to the Anglophone members' federalist demands. ${ }^{14}$

14 On that occasion, he claimed that the draft constitution had been drawn up by the technical committee. See Le Messager, 8 June 1993, p. 5. 
Shortly after the October 1992 presidential elections, President Biya announced that he intended to organise a national forum (un grand ou large débat) on constitutional reform. This announcement that was probably aimed at mitigating people's anger over the controversial elections, especially in Anglophone Cameroon, was reiterated in his New Year message to the nation on 31 December 1992. It was not until 23 March 1993 that Professor Augustin Kontchou Kouomegni, the minister of state in charge of communications and also a government spokesman, informed the Cameroonian people that the national forum on constitutional reform would be held from April to June 1993. In response to this announcement, the Anglophone members of the technical committee convened an All Anglophone Conference (AAC) from 2-3 April 1993 in Buea, the former capital of the Southern Cameroons, 'for the purpose of adopting a common Anglophone stand on constitutional reform and of examining several other matters relating to the welfare of ourselves, our posterity, our territory and the entire Cameroon nation'. ${ }^{15}$

The AAC turned out to be a landmark in the history of Anglophone Cameroon. It brought together over 5,000 members of the Anglophone elite and all the Anglophone associations and organisations were represented. CAM in particular played a leading role in the organisation of this conference. After two days of deliberations, the conference issued the Buea Declaration which stated that:

- the imposition of the unitary state in Southern Cameroons in 1972 was unconstitutional, illegal, and a breach of faith;

- the only redress adequate to right the wrongs done to Anglophone Cameroon and its people since the imposition of the unitary state was a return to the original form of government of the reunified Cameroon;

- to this end, all Cameroonians of Anglophone heritage were committed to working for the restoration of a federal constitution and of a federal form of government which takes cognisance of the bicultural nature of Cameroon and under which citizens will be protected against such violations as have here above been enumerated; and

- the survival of Cameroon in peace and harmony depended upon the attainment of this objective towards which all patriotic Cameroonians, Francophones as well as Anglophones, should relentlessly work. ${ }^{16}$

15 All Anglophone Conference (AAC) 1993: 8. For an interesting report on the organisation and proceedings of this conference, see 'The Untold Story of the All Anglophone Conference' in Cameroon Life, Vol. 2, No. 8, May 1993, pp. 8-15.

16 All Anglophone Conference (AAC) 1993: 29-30. 
The Buea Declaration listed the multiple Anglophone grievances about Francophone domination. Like previous documents written by Anglophone pressure groups, ${ }^{17}$ it tended to blame the 'wicked' Francophones as a whole for the plight of the 'poor' Anglophones, and compared both in rather idealised terms: the former, in full solidarity, agree among themselves to oppress the latter who, by their very nature, are peace-loving, open to dialogue, and committed to freedom. ${ }^{18}$ Of course, this demagogic approach, which is commonplace in ethno-regional discourse, serves to emphasise the insurmountable dichotomy that justifies the AAC call for autonomy and return to the federal state. This approach may be efficient in mobilising Anglophones but has hardly helped the struggle against their real enemy, the Francophone-dominated unitary state that has allies and opponents in all parts of the country. In addition, it tends towards a frozen and geographically restricted idea of being Anglophone, denies the existence of various ethnic links between Francophones and Anglophones, and creates serious obstacles to any Francophone sympathy for the Anglophone cause. ${ }^{19}$

Henceforth the AAC became the main Anglophone organisation and mouthpiece, responsible for the defence and representation of general Anglophone interests. All the existing and newly emerging Anglophone associations became auxiliary organisations of the AAC. Under the AAC umbrella they continued to carry out their own specific responsibilities. They were represented in the 65member Anglophone Standing Committee created by the AAC. Being the most important auxiliary association, CAM was well represented in the Anglophone Standing Committee, thus exerting an enormous influence on AAC policies. The three convenors of the AAC occupied leading positions in the Anglophone Standing Committee: Elad was its chairman, Anyangwe its secretary-general, and Munzu was its spokesman.

See, for instance, Mukong 1990 and Free West Cameroon Movement, op. cit., 1991.

See Louka (undated): 78-79; Sindjoun 1995: 93-94 and Fardon 1996: 93.

19 See, for instance, the warning of Professor Maurice Kamto, an eminent Francophone legal scholar, that 'Anglophones should blame the Ahidjo and Biya regimes, not Francophones', in Le Messager, 24 June 1993, p. 12. Indeed, because of such collective condemnation the French-language newspapers have been reluctant to admit the existence of an Anglophone problem in Cameroon. See, for example, $L a$ Nouvelle Expression, 13-17 January 1994, pp. 1-3 for the hostile reception experienced by Simon Munzu when trying to explain the Anglophone problem to Francophone journalists and intellectuals. It is only recently, thanks to the trivialisation of the whole idea of minorities in the 1996 constitution, that the Francophone press appears to be waking up to the concerns of the Anglophone minority. See La Nouvelle Expression. Dossiers et Documents, 23 May 1996, pp. 128, devoted entirely to 'Minorités, Autochtones, Allogènes et Démocratie' in Cameroon. 
One of the major tasks assigned to the Anglophone Standing Committee by the AAC was the drafting of a federal constitution as the Anglophone contribution to the national forum on constitutional reform to be organised by the government. The draft constitution eventually produced by the Anglophone Standing Committee ${ }^{20}$ proposed a loose form of federation that was clearly inspired by the recommendation of the 1961 Bamenda Conference (see Chapter 2). It displayed remarkable similarities with the United States federal system, including a federal house and senate, a presidential system, and procedures for impeachment, as well as with the 1994 Nigerian federal draft constitution, which accommodated several power-sharing devices such as a system of rotating presidency amongst the federal states and the development of criteria for the sharing of federal revenues (Olukoshi \& Agbu 1996).

As to the structure of the federal state, the authors proposed two levels of federation: an external federation composed of the erstwhile federated states of East and West Cameroon, and an internal federation composed of the provinces within each of the two federated states. By introducing an internal federation, the authors hoped to solve, or at least to diminish, the persistent problems of inter-ethnic and inter-provincial conflicts over the unequal distribution of employment, social services and development projects. Undoubtedly, this proposal of internal federation served the specific purpose of allaying any South West fears of North West domination in a future federal system. The proposed federal system would accord a large measure of political, economic, financial and fiscal autonomy to the two federated states, the provinces within each of the two federated states, and even the municipalities within the provinces.

The authors further proposed a strict division of powers between the legislative, executive and judiciary:

- All legislative power was to be vested in the legislatures, which would be bicameral at all levels. The federal legislature would be composed of a senate and a national assembly; the legislature of each of the federated states would be composed of a House of Representatives and a House of Traditional Chiefs; the legislature of each province would be composed of a Provincial Assembly and a Conference of Traditional Chiefs.

- As for the executive branch, the authors opted for a presidential system at the federal level. This choice seems to have been made for the following reasons. In the specific Cameroonian context of marked ethnic and regional diversities a presidential system was more likely to forestall administrative chaos and political instability than any other form of government. Moreover,

20 See Avant-Projet de Constitution de la République Fédéral du Cameroun, Buea: AAC Standing Committee, 1993. For a summary, see Konings 1999a: 311-16. 
it would enable the party in power to assume full responsibility for its policies and actions. The president and vice-president were to be elected on a single list by direct universal suffrage. The federal draft constitution provided some guarantees that citizens of both federated states would have access to the highest executive office at the federal level. Like the 1961 federal constitution, the draft stipulated that the president and vice-president could not come from the same federated state but unlike the former, it proposed a rotational system. The office of president could not be held by the same person for more than two consecutive five-year terms and, more significantly, that person had to be succeeded by a citizen of the other federated state. A similar rotational system would also apply to the highest executive authorities at state and provincial levels. The highest executive authorities at the level of the federated states were to be the prime minister and vice-prime minister, also elected on a single list by direct universal suffrage. The prime minister of a state would be accountable to the state legislative assembly and, like the president of the federal republic, could be subject to removal from office for serious misconduct or incapacity of whatever nature. The highest authority at the provincial level would be the governor. While governors were formerly nominated by the head of state, the federal draft constitution proposed that they be elected by direct universal suffrage for a maximum of two four-year terms.

- For the judiciary, the draft constitution outlined a system of justice that closely resembled the one proposed in the 1961 federal constitution. The chief justice, presiding over the Federal Supreme Court, would head a justice system comprising a federal supreme court, the supreme courts of the federated states, the provincial appeal courts and other less-influential and customary courts created by law.

Finally, the federal draft constitution provided two ways of revising the constitution. Parliament could revise any part of the constitution provided that two-thirds of its members voted in favour. However, any proposal for amendments which might affect the unity or the federal or republican character of the state would require the verdict of the people in a referendum, and would be approved only if at least sixty per cent of the electorate of both federated states participated in the referendum and endorsed the amendment.

On 26 May 1993, the Anglophone Standing Committee submitted the federal draft constitution to the technical committee, which had been enlarged by a recent presidential decree from its original 11 members to 29 members but was still chaired by Professor Owona. The national forum on constitutional reform which had been given wide publicity by the government turned out to be nothing more than an opportunity offered to Cameroonian citizens to forward 
any comments on the Owona draft constitution to the technical committee by mail, telephone or fax (Melone et al. 1996). Owona's refusal to give an undertaking that the technical committee would examine and report on the Anglophone federal draft constitution, which he described as a copy of the Nigerian constitution, provoked Elad, Munzu and Anyangwe, the three convenors of the AAC, to suspend their participation on the committee. On 23 June 1993, Owona stated on television that the technical committee had not been able to examine the federal draft constitution due to the absence of the AAC convenors during the committee's deliberations. The Anglophone Standing Committee then decided to publish the draft in English and French so as to inform the general public about the Anglophone problem and federalism.

Confronted with the government's persistent refusal to discuss the AAC constitutional proposals, CAM, the most important and influential Anglophone association affiliated to the AAC, increasingly adopted to a more radical position. Having once been a major champion of a return to the federal state, it was becoming more and more inclined to advocate secession. CAM, supported by other Anglophone associations with a secessionist agenda such as the Free West Cameroon Movement (FWCM), then tried to convince the Anglophone Standing Committee to take a secessionist stand as well. This gave rise to regular conflicts within the Anglophone Standing Committee between moderates who continued to adhere to a federalist programme and strategy in spite of the government's apparent unwillingness to enter into any meaningful negotiations on the one hand, and radicals who were striving for a secessionist programme and strategy, on the other. The moderates proved capable of controlling the Anglophone Standing Committee's activities for some time. Given this situation, CAM officially declared itself in favour of 'zero option', i.e. total independence for the Southern Cameroons. ${ }^{21}$ However, it stressed its pursuit of Southern Cameroons' independence through peaceful negotiation rather than through armed struggle. It thus remained faithful to the motto of the AAC: 'the force of argument and not the argument of force'. On 9 February 1994, CAM's National Executive unanimously agreed upon the Buea Peace Initiative (BPI), a blueprint for the peaceful and negotiated separation between the Southern Cameroons and La République du Cameroun, which was to be discussed at the next AAC Conference (AAC II). Interestingly, the BPI was inspired by the Czechoslovak experience: Czechoslovak leaders agreed on 20 June 1992 to amicably dissolve their federation into two separate and independent states and to engage in negotiations about any possible future cooperation. The BPI presented the following proposals:

${ }_{21}$ Cameroon Post, 1-8 December 1993, pp. 7-10; and Cameroon Life, Vol. 2, No. 10, October 1993, pp. 10-16. 
- that the Southern Cameroons and La République du Cameroun should agree to a formal separation into two independent states;

- that the territory of Southern Cameroons should reactivate its independence in the same way as La République du Cameroun had done in 1984, and sever all political and constitutional links with La République du Cameroun;

- that the two entities should negotiate economic and political protocols in the following areas:

o the exploitation of oil fields located in the territory of Southern Cameroons and the sharing of revenues therefrom in a just, fair and equitable manner,

- the joint ownership of the oil refinery at Victoria (Limbe) in the Southern Cameroons,

- the joint use of the electricity generated at Edea in La République du Cameroun,

- the joint ownership and management of Cameroon Airlines and joint access to the international airport at Douala in La République du Cameroun,

- a formula for sharing the external debt of Cameroon in a just, fair and equitable manner,

- the sharing of moveable assets belonging to the armed forces in a just, fair and equitable manner,

- the sharing of assets in foreign diplomatic missions,

- a timetable for the withdrawal of the civil servants of Southern Cameroons origin from the territory of La République du Cameroun, and

- a timetable for the introduction of a separate currency in Southern Cameroons.

- that the armed forces of La République du Cameroun should be withdrawn from the Southern Cameroons and that Southern Cameroonians serving in the armed forces of La République du Cameroun should be repatriated;

- that all Southern Cameroonians jailed by La République du Cameroun for political reasons should be released; and

- that the government of La République du Cameroun should renounce the use of force, violence, torture and imprisonment of Southern Cameroonians to solve political problems. ${ }^{22}$

The two major Anglophone options emerging in the process of constitutional reform - the choice between the demand for a return to the federal state and a (negotiated) separation - were also discussed in a lively manner during the Second All Anglophone Conference (AAC II) held in Bamenda from 29 April

22 The BPI is reproduced in Today, 29 April 1994, pp. 3-6. 
to 1 May 1994. The conference sought to consider the implications for Anglophone Cameroon of the Biya government's arbitrary suspension (for nearly a year) of the constitutional reform process, to evaluate the execution by the Anglophone Standing Committee of the mandate received from the AAC meeting in its first session in Buea in April 1993, and to examine other issues concerning the people and the territory of Anglophone Cameroon.

The conference reviewed all the futile attempts of the Anglophone Standing Committee to enter into negotiations with the Biya regime about a return to the federal state. It then decided to dissolve the Anglophone Standing Committee and replace it with an Anglophone Council. The tasks and strategy assigned to the new Anglophone Council were outlined in the so-called Bamenda Proclamation adopted by the conference and reflecting the compromise reached between moderates and radicals. ${ }^{23}$

The Bamenda Proclamation insisted that the Anglophone Council should first 'seek and secure constitutional talks between Anglophone and Francophone Cameroon on the basis of the federal draft constitution which was submitted by the Anglophone Standing Committee in May 1993'. It cautioned the Anglophone Council against accepting any arrangement that did not envisage the restoration of an Anglophone federated state within a Federal Republic of Cameroon. But 'should the government either persist in its refusal to engage in meaningful constitutional talks or fail to engage in such talks within a reasonable time', the Anglophone Council should 'proclaim the revival of the independence and sovereignty of the Anglophone territory and take all measures necessary to secure, defend and preserve the independence, sovereignty and integrity of the said territory'. The Bamenda Proclamation added that, upon the declaration of independence, the Anglophone Council should 'without having to convene another session of the All Anglophone Conference, transform itself into the Southern Cameroons Constituent Assembly for the purpose of drafting, debating and adopting a constitution for the independent and sovereign state of Southern Cameroons'. Subsequently, the independent Southern Cameroons should enter into negotiations with La République du Cameroun about 'their peaceful separation on the basis of the Buea Peace Initiative and on such other terms as shall be mutually beneficial'.

On 6 August 1994, shortly after the Bamenda conference, the Anglophone Council decided to change the names of the AAC, the Anglophone Council and the newly created Anglophone Advisory Committee composed of traditional rulers, elder statesmen, senior citizens, leading politicians and religious authorities. The AAC was renamed Southern Cameroons People's Conference

23 For the proceedings of AAC II and the Bamenda Proclamation, see Cameroon Post, 6-12 May 1994. 
(SCPC), the Anglophone Council was renamed Southern Cameroons National Council (SCNC), and the Anglophone Advisory Committee was renamed the Southern Cameroons Advisory Council (SCAC). According to an SCNC press release, 'the change of name makes it clear that the struggle led by the former $\mathrm{AAC}$ is neither of an essentially linguistic character nor in defence of an alien colonial culture, as has often been alleged, in bad faith, by some misguided critics of the AAC'. It stressed that the adoption of the name Southern Cameroons showed that the aim of the struggle had always been and remained 'to restore, within a newly restructured Federal Republic of Cameroon, the autonomy of a territory - Southern Cameroons - and of a people - Southern Cameroonians - and to put an end to their annexation by La République du Cameroun'. ${ }^{24}$

Renewed attempts by the SCNC to enter into negotiations with the Biya government failed. At the end of the same year, on 14 December 1994, President Biya issued a long-expected decree, creating a Consultative Committee on Constitutional Reform and summoning the said committee to begin work in camera in Yaoundé on 15 December 1994 and to submit to the president its non-binding advice on constitutional reform by 22 December 1994. The Anglophone Prime Minister, Mr Simon Achidi Achu, would chair the committee. In all 58 persons were invited, of whom 44 belonged to the CPDM or its allied parties. Fourteen were Anglophones, having been nominated on an individual basis. Biya thus simply ignored the list of the Southern Cameroons delegates mandated by the SCNC in accordance with AAC I and AAC II resolutions sent to him in November 1994. On 18 December 1994, the SCNC strongly condemned this exercise as falling short of the expectations of Cameroonians in general and Southern Cameroonians in particular for a meaningful constitutional reform. It underlined that Southern Cameroonians would not be bound by any decision taken by the Constitutional Consultative Committee since the Anglophone delegation had not been mandated by the SCNC. ${ }^{25}$ Seven of the 14 Southern Cameroonian participants, including Foncha and Muna, the Anglophone architects of reunification, soon withdrew from the committee's deliberations due to the failure of the government constitutional proposals to address the Southern Cameroons question and the committee's unrepresentative nature. ${ }^{26}$

24 The SCNC press release was reprinted in Cameroon Post, 16-23 August 1994, p. 3. For a discussion on the issue of names and renaming in the Anglophone struggles, see Nkoum-Me-Ntseny 1996a: 81-89.

25 See Cameroon Post, 22-29 December 1994, p. 6.

26 For Foncha's Statement of Withdrawal from the Constitutional Consultative Committee, see ibid. 
In reaction to growing pressures from several auxiliary organisations, especially CAM, claiming that the 'reasonable time' as prescribed by the May 1994 Bamenda Proclamation for engagement in meaningful constitutional talks on the restoration of federalism had expired, the SCNC sent a delegation to the United Nations in May 1995. At the end of that mission the delegation signed the so-called London Communiqué that was said "to mark the beginning of an irrevocable and irreversible process of the implementation of "zero option": total and unconditional independence of the Southern Cameroons'. Any future negotiations about independence should take place under the auspices of the United Nations and the BPI would form the only basis for any such negotiations (see below).

On 7 October 1995, the SCNC executive unanimously adopted the Independence Programme for the Southern Cameroons drawn up by CAM a week earlier. This programme scheduled the following main activities:

- September-October 1995: signature referendum in the Southern Cameroons on independence. The target was 1.35 million signatures by Southern Cameroonian citizens;

- November 1995: creation of a Constituent Assembly charged with the drafting of a constitution for the Southern Cameroons;

- February-March 1996: mission to the United Nations to file an application for independence and UN membership; and

- June-July 1996: negotiations with La République du Cameroun on the basis of the Buea Peace Initiative in the presence of representatives of the United Nations and the United Kingdom.

The first phase of the Independence Programme, the signature referendum, was duly organised in spite of the usual intimidation, harassment and brutalities by security forces. This referendum aimed to test the support of Southern Cameroonian citizens for the independence course taken by the SCNC, providing legitimacy for SCNC activities against the government. In April 1996, the SCNC released the results of the signature referendum. In all, 315,000 signatures were collected. Comparing this figure with the 472,316 voters who took part in the January 1996 municipal elections in the territory, this signified a voter participation of 75 per cent. No fewer than 99.97 per cent were reported to have voted in favour of independence. A closer look at the participants throws some doubts on the representativeness of the referendum. The vast majority of the participants appear to be older people, either retired or active in agriculture. No reasons are given for the remarkably low participation in the referendum of both young people and civil servants. In addition, there also 
appears to be a regional bias: participation in the Ngokitungia, Bui and Mezam Divisions was much higher than in other divisions of the Anglophone territory. ${ }^{27}$

Despite repeated declarations on the part of the SCNC that the other phases of the Independence Programme - notably the creation of a Constituent Assembly, the drafting of a new constitution and the official proclamation of independence - were about to be implemented, nothing actually happened. For example, 1 October 1996 was one of the dates set by the SCNC for the declaration of independence for the Southern Cameroons. The date came and went with nothing but an 'Independence Day' address by the new SCNC chairman, Henry Fossung. He called upon Southern Cameroonians to use their National Day as a 'day of prayer', asking God 'to save us from political bondage', and reiterating that independence was 'irreversible and non-negotiable' ${ }^{28}$ This is not altogether surprising. For a variety of internal and external factors that will be explored in this and the next chapter, the activities of the SCPC and its affiliated organisations were becoming rare or even dormant after the end of 1995.

With the promulgation of a new constitution on 18 January 1996, the government closed the process of constitutional reform in Cameroon for the time being. As expected, the new constitution ignored Anglophone demands for a federal state, opting instead for a 'decentralised unitary state'. While stressing the continuing unitary nature of the state, it allowed for a certain devolution of powers to the 10 planned regions corresponding with the current 10 provinces. While the preamble of the constitution clearly states that 'the state shall ensure the protection of minorities and shall preserve the rights of autochthonous populations in accordance with the law', one searches in vain for any specific reference stating that Anglophones belong among those minorities or autochthonous populations. ${ }^{29}$ Little wonder then that the SCNC was quick to reject the imposed constitution 'in its entirety as having no bearing on the territory of the Southern Cameroons'. Anglophones were implored to redouble their efforts in the struggle for independence and restoration of the 'statehood of the Southern Cameroons'. ${ }^{30}$

27 The results were published in Cameroon Post, 18-24 June 1996, pp. 6-7; and 25 June-1 July 1996, p. 6.

28 Cameroon Post, 8-14 October 1994 and The Witness, 12-18 November 1996.

29 For the 1996 constitution and its relevance to Anglophones, see Melone et al. 1996; Eboussi Boulaga 1997a; Olinga 1998; Konings \& Nyamnjoh 2000.

30 The Herald, 23-24 January 1996, p. 3; see also Newsweek Comm., 18-25 January 1996, p. 1. 


\section{The Anglophone diplomatic offensive}

The Anglophone leadership has made strenuous efforts to gain international support for their territory's autonomy in the form of either a return to the federal state or the creation of an independent Southern Cameroons state.

Following AAC I in April 1993, the Anglophone Standing Committee launched a diplomatic offensive to seek international support for the Anglophone pursuit of autonomy. It visited several embassies in Yaoundé. This effort was reinforced by a similar action by Dr John Ngu Foncha and Mr Solomon Tandeng Muna, the Anglophone architects of the federal state. The Anglophone Standing Committee also dispatched missions to selected countries in Africa, Europe and North America, entered into correspondence with the United Nations Secretariat and the Commonwealth Office, and applied for membership of the Unrepresented Nations and Peoples Organisation (UNPO) in The Hague. ${ }^{31}$ The UNPO works closely with the United Nations and has been primordial in the process that led to the independence of East Timor. Most SCNC leaders therefore believed that it could play a similar role in the case of the Southern Cameroons. ${ }^{32}$

One of the most spectacular activities of the SCNC was the sending of a nine-man delegation, including Foncha and Muna, to the United Nations on 19 May 1995. This delegation led by Barrister Sam Ekontang Elad, chairman of the SCNC, followed the example of two renowned Anglophone leaders, Fon Gorji Dinka and Albert Mukong, who had already made representations to the United Nations on behalf of the Anglophone minority in the late 1980s and early 1990s. These two Anglophone leaders shared a common experience in having been subjected to imprisonment, torture and frequent harassment in the Francophone-dominated state..$^{33}$ But they had developed different views on the solution of the Anglophone problem. Fon Gorji Dinka wanted nothing short of outright secession for the Southern Cameroons which, for reason of legality, he had renamed the Republic of Ambazonia with himself as head of state (see Chapter 3). ${ }^{34}$ Albert Mukong advocated instead a return to the federal state. After his single-handed battle to raise international awareness of the issue of

31 See Report of Activity of the AAC since its inception in April 1993, Presented to AAC II held in Bamenda from 29 April to 2 May 1994 by Dr Carlson Anyangwe, Secretary-General of AAC Standing Committee, in Cameroon Post, 6-12 May 1994, pp. 8-9.

32 See The Post, 7 February 2000, p. 3.

33 For his own sufferings under the Ahidjo regime, see Mukong 1985.

34 Fon Gorji Dinka has been living in exile since 1986. He refuses to return to Cameroon for this, according to him, would imply living and working under an illegal and illegitimate regime. 
Cameroon's federation during his exile, Mukong became a leading member of CAM. In November 1992 he led an official two-man delegation by CAM to the United Nations and the US State Department to continue the battle from the point where he had stopped it while in exile. ${ }^{35}$

The sending of a mission to the United Nations had been decided upon by the SCNC after the expiry of what the 1994 Bamenda Proclamation had called 'a reasonable time period' for entering into negotiations with the Biya regime. The purpose of the mission was to file a petition against 'the annexation of the Southern Cameroons by La République du Cameroun and to commit the international community to the Southern Cameroons' search for a peaceful solution to head off the dangerous conflict that was brewing between La République du Cameroun and the Southern Cameroons. ${ }^{36}$ In its London Communiqué, ${ }^{37}$ issued after its historic mission to the United Nations, the SCNC delegation stated that La République du Cameroun had unilaterally seceded from the union in 1984 when the Biya regime changed the country's name from the Federal Republic of Cameroon to the Republic of Cameroon the name of independent Francophone Cameroon prior to reunification. As a consequence, the Southern Cameroons question was no longer an internal problem of La République du Cameroun since there now existed two de facto distinct entities that were no longer bound by any legal or constitutional bond, the Southern Cameroons having reverted to its pre-independence situation, i.e. a United Nations Trust Territory. Under these circumstances, the Southern Cameroons demanded that the United Nations terminate its annexation by La République du Cameroun and grant full independence to its Trust Territory in accordance with Article 76 of the United Nations Charter. It was only after the granting of full independence by the United Nations that the Southern Cameroons could enter into negotiations with La République du Cameroun about any future constitutional or bilateral links on the basis of the BPI and under the auspices of the United Nations.

On returning home on 28 June 1995, the delegation was given a heroic welcome at the international airport in Douala. On its way back to Buea, the capital of Southern Cameroons, the delegation stopped at the Mungo River, the natural border between Francophone and Anglophone Cameroon. In a symbolic ceremony it crossed the Mungo Bridge to celebrate its return home and hoisted the UN flag on Southern Cameroons territory as a sign of the Southern Cameroons' current trust-territory status and future full independence. During a

\footnotetext{
See Mukong 1990.

3 See SCNC, Petition Against the Annexation of the Southern Cameroons, Buea, May 1995 (mimeo).

37 SCNC, The London Communiqué, London, 22 June 1995 (mimeo).
} 
subsequent SCNC rally held at the Bamenda stadium on 4 July 1995, the Fon of Bafut, a SCNC sympathiser, conferred the title of Lord upon Foncha and Muna in recognition of their key role in the promotion of Southern Cameroons' independence in the international community. ${ }^{38}$

It is beyond any doubt that the various missions of Anglophone leaders to the United Nations contributed to a growing awareness in UN circles of the Anglophone problem. Soh (1999: 243) claims that Foncha was scheduled to address the United Nations General Assembly on the Anglophone problem in September 1999 but unfortunately died before then, on 10 April 1999. It is difficult to ascertain the truth of this claim. On the one hand, it is rare for anyone who is not a head of state to address the United Nations General Assembly. On the other hand, there is sufficient evidence that UN leaders had become increasingly concerned about the possibility of the outbreak of another violent ethno-regional conflict in West-Central Africa. During his visit to Cameroon in May 2000, the UN Secretary-General, Kofi Annan, pleaded for dialogue between Francophone and Anglophone leaders. During a press conference shortly before leaving Cameroon, he said:

I leave Cameroon with the impression that there is only one Cameroon, multilingual and multi-ethnic. I encourage a dialogue of these stakeholders. In every country there are problems of marginalisation. The way it has to be solved is by dialogue and not by walking away. ${ }^{39}$

Whereas the SCNC in conformity with its motto 'the force of argument' was ready to accept Annan's proposal, the Biya government simply turned a deaf ear. The SCNC implored the UN Secretary-General to convince Biya to accept it and 'to employ the resources and know-how of the United Nations to participate in, and oversee the success of, [this] dialogue'. ${ }^{40}$

The Anglophone leaders were also engaged in intensive lobbying to forestall the Republic of Cameroon's admission into the Commonwealth and to file instead a Southern Cameroons' application for Commonwealth membership.

Before reunification it had been agreed between Ahidjo and Foncha that the Federal Republic of Cameroon would desist from seeking membership of either the French community or the Commonwealth of Nations (see Chapter 2). In 1989, however, the Biya government reversed Cameroon's foreign policy, applying for membership of both the Francophonie and the Commonwealth.

38 See 'SCNC Homecoming' in Cameroon Post, 3-10 July and 10-17 July 1995; see also La Nouvelle Expression, 4-7 July 1995, p. 6.

39 See 'Annan Ends African Tour, Seeks Cameroon Dialogue' on scncforum website, 4 May 2000.

40 The Post, 11 August 2000, p. 3. 
While the former promptly granted admission to the Republic of Cameroon, the Biya government found it hard to join the Commonwealth.

During the 1991 Commonwealth Summit in Harare, Cameroon's application was rejected on the grounds that it still failed to meet the criteria for membership stipulated in the Harare Declaration, namely the establishment of a democratic system, good governance and respect for human rights. In June 1993, the Nigerian Secretary-General of the Commonwealth, Chief Emeka Anyaoku, visited the country at the government's request to see whether the Republic of Cameroon met the conditions for admission. Chief Anyaoku was then virtually hijacked by the Anglophone leadership, which succeeded in subverting the tight programme drawn up by the Biya government and in familiarising the Commonwealth secretary-general with their plight. Memoranda were presented by 19 Anglophone leaders, elderly statesmen and traditional rulers in Bamenda as well as by the Anglophone Standing Committee in Victoria (Limbe). ${ }^{41}$ In these memoranda, the Anglophone leadership urged Chief Anyaoku to keep Cameroon out of the Commonwealth until the government had realised significant democratic reforms, improved upon its poor human rights record and accepted the Anglophone proposal for a federal structure. As an alternative, the Commonwealth should consider granting the Southern Cameroons either full membership of the organisation or some form of status acceptable to the Commonwealth in recognition of the fact that Southern Cameroonians cherished the same values as the Commonwealth and that they, in their struggle for the preservation of their Anglophone identity, had been exposed to various acts of oppression and assimilation by successive Francophone regimes in Cameroon.

At the October 1993 Commonwealth Summit in Limassol, Cyprus, Cameroon's admission was again postponed. It was then decided that Cameroon's application would be reconsidered at the next Commonwealth summit in 1995 provided that 'the country's current efforts to establish a democratic system consistent with the 1991 Harare Declaration would by then have been completed'. There is no doubt that both Chief Anyaoku's report and the intensive lobbying by the uninvited two-man delegation sent by the Anglophone Standing Committee to the Limassol Summit influenced the Commonwealth's eventual decision to postpone Cameroon's admission.

Barely four months before the next Commonwealth summit in Auckland in July 1995, a Commonwealth Eminent Persons Mission led by Dr Kamal Hossain, chairman of the Commonwealth Human Rights Initiative, arrived in the country 'to restudy Cameroon's application for admission into the

${ }_{41}$ See Cameroon Life, July-August 1993, p. 15; and Cameroon Post, 29 June 1993, pp. 4-5. 
Commonwealth of Nations'. ${ }^{42}$ While the Biya government was pressing for admission, the SCNC made the mission understand that La République du Cameroun, with a continuously notorious record of human rights violations, had no mandate to apply for Commonwealth membership on behalf of the Southern Cameroons. After the SCNC had requested in its June 1995 London Communique that the United Nations grant full independence to its Trust Territory, the Southern Cameroons was about to acquire the sovereign status that would enable it to qualify for Commonwealth membership directly. Consequently, admission of La République du Cameroun into the Commonwealth would be considered as an act hostile to the Southern Cameroons because it would be tantamount to accepting its annexation by La République du Cameroun.

To the consternation of Anglophone leaders, it was announced on 16 October 1995 that Cameroon had been admitted into the Commonwealth. There appear to be two main reasons for its admission. First, the Commonwealth found it hard to reject Cameroon's application on the basis of the 1991 Harare Declaration as there was ample evidence that the democratic records of some of its African member states, like Nigeria and Kenya, were even poorer than that of Cameroon. Second, the Commonwealth generally believed that admission would be a more effective option than non-admission in terms of the advancement of the democratisation process in Cameroon. Once in, Commonwealth members would bring pressure to bear on the Cameroonian government to introduce political reforms. The Report of the Eminent Persons Mission and the debate in the British House of Lords a few days after the announcement of Cameroon's admission provide some evidence to support this explanation. For instance, in her reply to criticisms expressed in the House of Lords about British support of Cameroon's admission, Baroness Lynda Chalker, Minister for Overseas Development responsible for Commonwealth Matters, stated:

British support is based on the Report of the Eminent Persons Mission. The report holds that sufficient progress has been made in Cameroon consistent with the principles of the Harare Declaration, over the past five years.

The report nevertheless highlights areas that Cameroon would have to address still further. These areas include further constitutional reform: local elections, press freedom, human rights and the independence of the judiciary.

There is progress, but we shall continue to keep up pressure on Cameroon, together with our Commonwealth partners, to make sure that reforms take place. ${ }^{43}$

42 Cameroon Post, 24-31 July 1995, p. 3.

43 The debate in the House of Lords is recorded in The Herald, 26-29 October 1995, pp. 1 and 3. See also Taku 1996. 
In reaction, the SCNC strongly condemned the Commonwealth for Cameroon's admission, accusing it of a blatant lack of sensitivity in a complex and explosive situation and of frustrating the political aspirations of the Southern Cameroonian people. Britain in particular was blamed for its 'second treachery' towards the Southern Cameroons cause, the first having occurred in the pre-reunification period (see Chapter 2). ${ }^{44}$ The SCNC later sent a two-man delegation to the November 1995 Commonwealth Summit in Auckland. The delegation pointed out that the previous conditions laid down for Cameroon's admission had not been fulfilled. Simultaneously, it pleaded for a Quebec-style independence referendum for the Southern Cameroons and filed an application for separate membership. It was told to resubmit its application for separate membership at the Glasgow Summit in 1997, if by then the Anglophone problem had not been satisfactorily resolved ${ }^{45}$ Having lost confidence in the Commonwealth leadership, the SCNC did not follow this advice.

In their diplomatic offensive, the Anglophone leaders have scored some success in their relations with France. Generally speaking, France has continued to support the Francophone-dominated regime in Cameroon during the current economic and political crisis (Konings 1996a). Besides the various agreements of cooperation between France and Cameroon, there are other factors to explain this French support. First, there was the emergence of the Anglophone factor during the political liberalisation process, which appeared to threaten French interests in Cameroon. In the first years of the SDF's existence, its chairman, John Fru Ndi, never concealed his resentment of French neo-colonialism and his pro-American stance. Fru Ndi's anti-French rhetoric coupled with his call for a boycott of French goods was not well received. Not surprisingly, France opposed Fru Ndi's candidacy in the 1992 presidential elections. The growing popularity of the Anglophone movements was regarded as an additional Anglophone threat to France's superior interests in Cameroon. These movements fuelled the existing anti-French sentiments in Anglophone Cameroon, and their call for federalism or secession formed a major challenge to French control over Cameroon and its stake in the oil industry located in Anglophone Cameroon (Ndzana 1987; Jua 1993). Second, there was a widespread belief in French circles that American decision-makers in Washington were exerting too great an influence on the policies of not only the International Monetary Fund (IMF) but also of the Anglophone opposition.

Gradually, however, some changes could be observed in French policy towards Anglophone Cameroon. The following factors appear to have been

44 See L'Expression, 20 October 1995, p. 4.

45 Cameroon Report, 18 October 1995, p. 4; The Herald, 20-22 November 1995 and The Herald, 6-8 May 1996. 
responsible for this remarkable change. Discontent was growing in the French administration with the Biya government's poor economic and political performance and its condoning of large-scale corruption. The former French Prime Minister, Edouard Balladur, was reported to regard the Cameroonian political system as a one-party democracy and the government as no better than a bench of incompetent and dishonest men who had run a once-buoyant economy into ruin. ${ }^{46}$ For similar reasons, relations between President Chirac and President Biya became strained for a time, allegedly because of political miscalculation by the latter of backing the losing candidate in the race for the French presidency (Konings \& Nyamnjoh 1997: 222-23). Moreover, it was becoming manifest that France was seeking to enhance its influence in the English-speaking part of Africa, as evidenced by growing French interests in Nigeria and South Africa. Above all, the French administration had become increasingly convinced that its making of some overtures to the Anglophone opposition parties and movements could be of greater benefit to long-term French interests in Cameroon than outright hostility. Though remaining somewhat suspicious of French intentions, the Anglophone opposition parties and movements came equally to recognise that French attempts at rapprochement might be of mutual advantage.

A few months after arriving as French ambassador to Cameroon in 1993, Gilles Vidal did what none of his predecessors had ever previously done: he visited Buea and Bamenda and conferred with Anglophone leaders, including John Ngu Foncha, and later organised a meeting with members of the Anglophone Standing Committee to familiarise himself with the objectives of the AAC. The French simultaneously started funding a number of development projects in Anglophone Cameroon. Vidal's successor, Philippe Selz, was equally keen to keep in touch with the opposition, even dining with the SDF chairman, John Fru Ndi, on his ambassadorial tour of French-sponsored projects in the North West Province in April 1996. ${ }^{47}$

As a result of these rapprochement attempts by the French, Fru Ndi stopped calling for a boycott of French goods. He had visited France several times to request that the French government exert pressure on the Biya government to speed up the process of economic and political reform in Cameroon. The French authorities, in turn, appear to have not been happy with the fact that the SDF, the main opposition party in Cameroon, had been excluded from all decision-making bodies in the country for a long time. They were therefore pleased that the SDF decided to take part in the 1997 parliamentary elections and even to take their seats in parliament despite allegations of widespread

46 Cameroon Post, 16-22 April 1996, pp. 1 and 6.

47 Cameroon Post, 23-29 April 1996 and The Rambler, 30 April-6 May 1996. 
rigging of the elections by the ruling CPDM. Undoubtedly, the French were also the brains behind the later negotiations between the Biya government and the SDF about possible SDF participation in government. These negotiations failed, however, mainly because of disagreement over SDF demands for the creation of an independent electoral commission. ${ }^{48}$

While appreciating an improvement in mutual relations, the Anglophone Standing Committee and the SCNC nevertheless remained somewhat cautious of French rapprochement attempts. They have often been inclined to interpret these attempts as a French strategy to lure Anglophone movements away from pressing for a return to federalism or secession. That such caution is not completely unjustified became evident when the French presidency addressed a correspondence to the SCNC in February 1996 appealing to it to accept the decentralisation proposals in the new constitution and to seek dialogue with the Biya government, as it might be advantageous to its promotion and defence of Anglophone interests. ${ }^{49}$ The SCNC immediately rejected these recommendations but it simultaneously tried to allay French fears about an independent Southern Cameroons state by pledging protection. The SCNC equally requested the Chirac administration use its considerable influence within the UN Security Council to get the execution of a Quebec-type referendum in the Southern Cameroons approved.

\section{The Anglophone leadership's 'sensitisation campaign'}

From the start, the Anglophone leadership made considerable efforts to transform Anglophone organisations from elitist movements into mass movements. It attempted to raise the consciousness of the Anglophone people about their region's subordinate position within the Francophone-dominated unitary state and to mobilise them for action in its pursuit of federalism or secession. To this end, it organised frequent meetings and rallies throughout the Anglophone territory to make the population aware of the Anglophone organisations' goals, programmes and strategies. In this endeavour, it was given invaluable assistance by the Anglophone media, in particular the press, which constantly reported any matter related to the Anglophone cause (see Chapter 5). Of great importance to the sensitisation campaign were also the regular strikes, demonstrations and boycotts organised by the leadership of the various Anglophone organisations, notably CAM, to protest against any injustices committed by the

48 See the SDF's 10-page position statement in The Herald, 6-8 February 1998, pp. 1 and 3.

49 Cameroon Post, 16-22 April 1996, pp. 1 and 6. 
Francophone-dominated state against the Anglophone minority. A few examples will suffice here. On 11 August 1993, CAM organised a Southern Cameroons Solidarity Day to protest against the brutal occupation of the South West Province by government troops under the pretext of controlling the largescale smuggling of Nigerian goods, especially petrol, into the province. ${ }^{50}$ The Anglophone Standing Committee called for a general strike on 14 February 1994 to protest against 'the government's failure to meet the preconditions set out by trade unions for the on-going government employees' strike to be called off'. ${ }^{51}$

The Anglophone leadership's sensitisation campaign was quite successful during the 1992-1995 period This was particularly apparent during the 'sensitisation tour' organised by the SCNC throughout the Anglophone territory in July-August 1995 following the return of its delegation to the United Nations. Large crowds attended the SCNC rallies, praising the delegation for its historic mission to the United Nations and pledging their support for the SCNC's new push for total independence for the Southern Cameroons. When security forces tried to prevent the SCNC delegation from entering Kumba in the South West Province, thousands of people chased them away, thus securing the delegation's triumphant entry into the town. ${ }^{52}$

From 1996 onwards, however, the Anglophone leadership's sensitisation campaign came to a virtual standstill as a direct consequence of the general loss of momentum of the Anglophone struggle. Besides the largely successful government attempts to contain the Anglophone danger (see Chapter 5), there are also internal factors explaining this unfortunate development. One of the most important was the resignation of the founding fathers from the SCNC leadership. The SCNC chairman, Barrister Sam Ekontang Elad left mainly for health reasons..$^{53}$ Constantly harassed by security forces, Drs Carlson Anyangwe and Simon Munzu departed to take up jobs in Zambia and Rwanda respec-

50 Cameroon Post, 12-19 July 1993, p. 11; Cameroon Life, Vol. 2, No. 10, October 1993, pp. 10-26.

51 Cameroon Post, 14-17 February 1994, p. 3.

52 For these SCNC rallies, see 'SCNC Hits Kumba: 75000 Jam Town Green', in The Herald, 3-6 August 1994, p. 1, and 'As Elites Condemn Military Occupation: SCNC Plans Operation Storm Mamfe', in Cameroon Post, 14-21 August 1995. See also Cameroon Post, 28-30 August 1995, p. 3.

53 Elad had previously come under severe attack on 21 August 1995 after repeated radio and television announcements to the effect that he had issued a press release informing the Cameroonian population of the suspension of the SCNC sensitisation tour in the aftermath of the historic SCNC mission to the United Nations. Although he could prove that he had been a victim of a government plot to compromise him and the SCNC, some people nevertheless continued to accuse him of having been bribed by the government. See The Herald, 24-27 August 1995. 
tively. ${ }^{54}$ The new leadership chaired by Henry Fossung, a former ambassador, appeared incapable of devising an adequate strategy to counteract the government's divisive and repressive tactics. It clearly failed to further exploit the unexpected successes registered between 1992 and 1995. Apart from declarations and proclamations, the new leadership had little to offer the restive Anglophone population. Despite the SCNC promises in its New Year message that ' 1997 would mark a turning point in our strategy' and that 'we are determined to culminate the process of our total restoration to its logical conclusion', many Southern Cameroonians were rapidly losing confidence in the new SCNC leadership. ${ }^{55}$ Perhaps this would explain why many Anglophone youths, especially in the diaspora, began to create and execute their own agenda for reclaiming self-determination in the free spaces of the Internet. Given this leadership problem and the government's persistent reluctance to enter into any negotiations, a conflict developed within the Anglophone movement between the doves - those who continued to adhere to a negotiated separation from La République du Cameroun - and the hawks - those who had come to the conclusion that the independence of Southern Cameroons could only be achieved through armed struggle. The Southern Cameroons Youth League (SCYL) in particular opted for the latter strategy.

The SCYL emerged in the mid-1990s as one of the many Anglophone associations operating under the umbrella of the SCNC. Being composed of 'young people who do not see any future for themselves and who would prefer to die fighting than continue to submit to the fate imposed on Southern Cameroons by La République du Cameroun', ${ }^{56}$ the SCYL tried to become the militant wing of the SCNC. Its original leadership was largely made up of Anglophone members of the former University of Yaoundé students' union, the so-called Parliament, which was engaged in several violent confrontations with the university authorities and the Biya government during the 1990-1996 period (Konings 2002). The SCYL soon became dissatisfied with the SCNC whose leadership continued to cling to a strategy of peaceful dialogue with the Francophone-dominated state for either a return to a federal state or outright secession, as manifest in its motto 'the force of argument', notwithstanding the Biya government's persistent reluctance to enter into negotiations with the SCNC and its ruthless repression of SCNC activities. The SCYL leadership broke off relations with the SCNC in November 1996 and placed itself under the umbrella of CAM, that in the meantime had changed its name to the

54 See Cameroon Post, 4-9 June 1996 for 'Change at the Helm of SCNC: Elad Dropped, Fossung is New Chairman'.

55 Cameroon Post International, 2 October 1997, p. 7.

56 See Mr Fidelis Chiabi, chairman of the former Anglophone Youth Council, in Cameroon Post, 1-2 February 1994, p. 7. 
Southern Cameroons Restoration Movement (SCARM). It now aimed to create an independent Southern Cameroons state through armed rebellion.

In the process of preparing for action in both Anglophone provinces, the SCYL was unexpectedly faced with the detention of its chairman, Mr Ebenezer Akwanga, following the failure of its members to steal explosives from the Razel Company in Jakiri in the North West Province during the night of 23-24 March 1997. It immediately reacted by attacking military and civil establishments in the Bui and Mezam Divisions of North West Province between 27 and 31 March 1997. According to official reports, three gendarmes and seven unidentified assailants were killed in these operations. Government repression of this ill-planned revolt was out of all proportion. It ruthlessly killed, tortured, raped and arrested several local men and women, forcing even more to go into exile. Above all, it seized the opportunity to clamp down on the SDF and SCNC, accusing both organisations of being responsible for the uprising. ${ }^{57} \mathrm{~A}$ considerable number of SCNC members were arrested and imprisoned in Yaoundé. Some died while in prison and others were not brought to trial until 1999 when they were not treated as political prisoners but were charged with criminal offences. ${ }^{58}$

The SCNC chairman, Henry Fossung, who had gone into hiding after the revolt, publicly denied any SCNC involvement, insisting "that the SCNC motto "the force of argument and not the argument of force" has remained today as valid as yesterday' ${ }^{9}{ }^{59} \mathrm{He}$ instead claimed that the incident had been orchestrated by a desperate government in an attempt to frustrate the legitimate struggles of the Southern Cameroonian people to restore their independence. Strikingly, following this revolt, the SCNC leadership appeared to be even less inclined to sensitise and mobilise the Anglophone population. Dissatisfied with Fossung's leadership, some SCNC leaders staged an internal coup in December 1998 nominating Prince Ndoki Mukete, the then vice-chairman of the SCARM, as the new SCNC chairman. Other SCNC leaders, like Foncha and Muna, however, continued to recognise Fossung as the SCNC chairman. Factionalisa-

57 In a report that was full of factual errors and based on spurious evidence, Jeune Afrique Economie supported the Biya government's allegation that the SCNC was responsible for the revolt. See Jeune Afrique Economie, No. 239, 14 April 1997, p. 8. The journal's support of the Biya government's allegation is not altogether surprising. Titus Edzoa, a former secretary-general at the presidency, once revealed that the journal was used for public relations purposes by the regime. To this end, the regime had funded the journal to the tune of FCFA 1.5 billion (or US\$ 3 million).

58 This account is based on various SCYL reports and interviews with the SCYL leadership. For an extensive discussion of the SCYL activities during the period 1995-2002, see Konings 2003.

59 Le Messager, 23 April 1997, p. 8. 
tion within the SCNC became a frequent source of internal conflict and proved harmful to the Anglophone cause.

It was in these circumstances and in a sense of despair that Justice Frederick Alobwede Ebong, an SCNC activist with close ties to the SCYL, ${ }^{60}$ took over the Cameroon Radio and Television (CRTV) station in Buea on 30 December 1999, proclaiming the restoration of the independence of the Federal Republic of Southern Cameroons (FRSC). ${ }^{61} \mathrm{He}$ was subsequently detained in Yaoundé where he applied for FRSC membership of the United Nations, the Organisation of African Unity (OAU), the Commonwealth, the Non-Aligned Movement and the Economic Community of West African States. ${ }^{62}$ During an SCNC meeting on 1 April 2000, Ebong was nominated chairman of the SCNC and first head of state of the FRSC. Dr Nfor Ngala Nfor, who used to be the chairman of the SDF Constitutional and Political Affairs Committee, was elevated to the positions of vice-chairman of the SCNC and, in the absence of Ebong, acting president of the FRSC. The then second vice-chairman of the SDF, Dr Martin Luma, chaired the historic meeting. Fearing that these developments would cause a loss of Francophone membership, the SDF leadership decided to purge some leading separatists from the party.

With a view to endowing the FRSC with all the attributes of statehood as well as guaranteeing state continuity, the FRSC Constituent Assembly meeting in Bamenda in May 2000 adopted resolutions on the coats of arms, the flag, and the national anthem. ${ }^{63}$ Subsequently, a flag was designed and the national anthem, Freedom Land, was released. ${ }^{64}$ Undoubtedly, these developments gave a new impetus to the Anglophone struggle. This is evidenced by the fact that after years of vehement conflict about policies and strategies, four of the major Anglophone organisations, namely the SCNC, the Ambazonian Movement (AM), the SCARM and the SCYL, agreed in 2001 to form an alliance for the purpose of achieving the independence of the territory of the Ex-British Southern Cameroons. During a summit in Washington in June 2001, representatives of the territory adopted the so-called Washington Proclamation of the Statehood of Ex-British Southern Cameroons, 'confirming the declaration of separate independence of the Southern Cameroons already made by Justice

60 Justice Ebong was largely unknown to the public. In March 1998 he was elected as the chairman of the SCNC High Command Council.

${ }_{61}$ For the full text of Justice Ebong's declaration of independence of the territory, see The Post, 24 January 2000, p. 7.

62 Today, 18 April 2000, pp. 3-4.

${ }_{63}$ Postwatch, No. 6, January 2001, p. 8.

${ }^{64}$ The Post, 13 November 2000, p. 3. 
Ebong in Buea on 30 December 1999', and decided to set up the British Southern Cameroons Provisional Administration. ${ }^{65}$

A further interesting development is that Anglophones are increasingly turning to the Internet as a vehicle for airing their views on various aspects of their predicament, centring mostly on their territory and community as victim of gross mismanagement by a corrupt and inefficient Francophone-dominated state and government. Their main channels on the Internet include web pages, discussion and mailing groups such as Scncforum, Camnet, Camnetwork, and SDF Forum. These are created and managed by Anglophone youths, mostly Grassfielders of the North-West Province, and mainly by those based in the diaspora, principally the United States. Because of their influential nature, these mailing and discussion groups have attracted even the state, which has normally been indifferent in the past. Government departments and individual members of the CPDM with vested interests in the status quo now monitor the content and react to what is written or discussed on a daily basis. Given the flexible nature of the Internet, real identities of users can be hidden under ambiguous user names, making provocative and fearless exchanges easier. Those who participate in the discussions are Anglophones both in Cameroon and the diaspora, pro-government or pro-SDF or proSouthern Cameroons independence. Among them are the most radical as well as the most conciliatory. This clearly highlights the importance of the Internet in providing space for Anglophone issues where the Cameroonian state has always stifled debate or monopolised the conventional media. Strikingly however, discussions even at this level tend to reflect the same tensions and multiple divisions that the politics of belonging and autochthony have brought to the fore (see Chapter 5). The Internet not only shapes what is discussed in society but also reflects the inherent divisions that autochthony brings about.

\section{Conclusion}

The current political liberalisation process in Cameroon has offered Anglophones a long-awaited opportunity to organise for the representation and the defence of their interests. The newly created organisations, in particular the AAC and the SCPC, have managed to reintroduce federalism and secession onto the country's political and constitutional agenda. In the pre-reunification period, secession ultimately became a minority option in the Southern Cameroons, federalism being the basis of constitutional negotiations between

${ }_{65}$ See British Southern Cameroons Summit, Resolutions, Washington, 17 June 2001 (mimeo) and Washington Proclamation of the Statehood of Ex-British Southern Cameroons, Washington, 17 June 2001 (mimeo). 
La République du Cameroun and the Southern Cameroons. In the current political liberalisation period, secession became a majority option in the Southern Cameroons only after La République du Cameroun had persistently refused, during the national forum on constitutional reform, to enter into any negotiations about a return to the federal state. Having been forced by such a negative government response to abandon its preferential option of federalism, the Anglophone leadership then sought the support of the international community and Anglophone population for the proclamation of Southern Cameroons' independence.

This chapter has shown that leadership problems and growing disagreements within the Anglophone movement on the strategy to be employed in the achievement of independence for the Southern Cameroons - the choice between 'the force of argument' and 'the argument of force' - contributed to the apparent loss of momentum of the Anglophone struggle after 1996. Recent developments, including the proclamation of Southern Cameroons' independence by Justice Ebong on 30 December 1999 and the formation of a British Southern Cameroons Provisional Administration in 2001, have given a new impetus to the Anglophone struggle. 


\section{Strategies of the Biya government to deconstruct the Anglophone identity}

It is hardly surprising that the Biya government has been keen to deconstruct the Anglophone identity that has tended to unite people in the Anglophone territory across ethnic-regional boundaries based on a common colonial heritage and a collective feeling of frustration at Francophone domination in the post-colonial state.

This chapter shows the variety of strategies that the regime has employed to neutralise the Anglophone danger. The 1994 Bamenda Proclamation mentions that 'rather than address the issue', the Biya government has chosen 'to feign ignorance of the Anglophone problem ... to seek by diverse manoeuvres to create division within the Anglophone nation with the aim of giving the false impression that there is no general consensus within it on constitutional reform ... and to accuse the All Anglophone Conference and its affiliated organisations unjustly and falsely of having adopted a secession of Anglophone Cameroon as their goal'.

The strategies outlined in the Bamenda Proclamation are by no means exhaustive. In this chapter we outline the Biya government's most important strategies under the following headings:

- trivialisation and demonisation of the 'Anglophone problem';

- divide and rule; 
- the establishment of direct and indirect control over the mass media; and

- repression.

While such strategies have undoubtedly posed formidable obstacles to the advancement of the Anglophone cause, we provide evidence to show that they have never been completely successful.

\section{Trivialisation and demonisation of the Anglophone problem}

The Biya government has often tried to minimalise the Anglophone-Francophone divide by highlighting the existence of a common identity under German colonial rule and the official recognition in all the post-colonial constitutions of the bilingual and multicultural nature of the Cameroonian nation. The latter is said to guarantee the preservation of the differential linguistic and cultural heritage of the post-German colonial era. In a speech in Bamenda on 13 December 1991, Biya stressed:

Let us not oppose Anglophones and Francophones... The language barrier is not and should not be a political problem in our country. Mind you, at the start of this century Cameroonians were neither Anglophones nor Francophones. Why should the wars of others and the culture of others divide Cameroonians at the dawn of the third millennium ${ }^{1}$

Meaningful though this argument would be in any country with a clear sense of vision, it has failed in the Cameroonian context to convince the Anglophone minority in the absence of any institutionalising mechanisms for weakening the strong grip on the state by Francophones and the superiority accorded to the French language and Francophone cultural values over everything Anglophone or English.

In an attempt to convince his national and international opponents that Cameroon's policy of bilingualism had been successful, Biya claimed in 1999 that secessionist tendencies were being manifested only by a tiny Anglophone minority and that 'he was ready to even call for a referendum, if it became necessary'. ${ }^{2}$ In reaction, English-speaking Cameroonians in North America challenged him to prove his claims. They even pledged to bear the costs of the organisation of a referendum if it was organised under United Nations supervision. ${ }^{3}$

1 Speech by President Biya in Bamenda on 13 September 1991, in Playdoyer pour une Vraie Démocratie, Yaoundé: Imprimerie Saint Paul, 1991, p. 68.

2 See Jeune Afrique, No. 1990, 2 March 1999.

3 The Post, 27 September 1999, p. 3. 
The Biya government has often argued that the unitary state is a more suitable form of state in the Cameroonian multi-ethnic context than a federal state and, moreover, corresponds with the wish of the vast majority of the population. Contrary to Anglophone claims that the unitary state came into existence in 1972 as a result of Ahidjo's illegal, unconstitutional and repressive manipulation, Biya has continually insisted that the unitary state was the outcome of the massive vote by the Cameroonian people as voluntarily expressed in the 1972 referendum. In reply to the Anglophone demand for a return to the federal state, Biya has claimed, like Ahidjo, that this tends to be costly, weak as far as state power is concerned, and divisive, provoking ethnic and regional sentiments rather than a national consciousness. He has apparently overlooked the fact that the unitary state's patrimonial tendencies and its politicisation of ethnicity may be even more costly and divisive (Chabal \& Daloz 1999; Gabriel 1999). While repeatedly declining to discuss the federal or so-called 'two-state option', he eventually expressed his willingness to concede a certain degree of decentralisation within the unitary state based on the present ten provinces in Cameroon, the so-called 'ten-state/region option'. ${ }^{4}$ On 30 April 1993, Biya declared:

The unitary state is the result of a referendum ballot, being thus the wish of Cameroonians. The unitary state is the form of state that suits Cameroon best. What needs still to be done is to ameliorate this management technique ... through reforms pertaining to decentralisation. ${ }^{5}$

His preferential option of a decentralised unitary state was eventually reflected in the 1996 constitution. Significantly, Biya has failed to implement these constitutional provisions. In his 20 May 2001 address to the nation, he told the Cameroonian public that decentralisation was a 'delicate and complex matter' over which he was still having 'profound reflections'. Decentralisation, he said, touched upon natural equilibrium, national unity and also powersharing between the centre and the regions.

From the very start, the Biya government has also tried to demonise the Anglophone call for federalism by equating federalism with secession. Its persistent suspicion that secession was the 'hidden agenda' of the Anglophone strive for federalism led to brutal repression of some Anglophone demonstrations, such as their celebration of Independence Day and attendant hoisting of the federation flag on 1 October 1993. The Biya government was in the habit of presenting the generally moderate Anglophone leaders, who continued to advocate peaceful negotiations rather than armed rebellion, as extremists and

4 See 1996 Constitution, Article 61, Paragraph 1.

5 Cameroon Tribune, 3 May 1993, p. 3. 
radicals. The fact that the Anglophone elite has not been united in their quest for recognition and/or a return to federalism has only compounded the trivialisation and demonisation of Anglophoneness by the Biya regime.

\section{Divide and rule}

Like his predecessor, Biya has attempted - with considerable success - to divide the Anglophones, often capitalising on the existing contradictions between the North West and South West. In response to South West complaints about North West domination, he appointed members of the South West elite to key positions in their province (Konings \& Nyamnjoh 1997; Eyoh 1998a and b). For example, Peter Mafany Musonge replaced the North Westerner John Niba Ngu as general manager of the Cameroon Development Corporation (Konings 1993a), Dorothy Njeuma was appointed vice-chancellor of the newly created Anglophone University of Buea and Becky Ndive was transferred from Yaoundé to head the Cameroon Radio and Television (CRTV) station in the South West. In addition, Biya has sought to use his allies among the Anglophone 'traditional' and 'modern' elite for the defence of the unitary state in exchange for rewards in the form of appointments, sinecures and the turning of a blind eye to corruption and/or embezzlement by those in high office. His allies, in turn, have tended to blame the leaders of the various Anglophone movements for their 'demagogic and irresponsible' calls for federalism or secession and to dispute their claims of being spokesmen of the Anglophone community, blaming them, as did Prime Minister Peter Mafany Musonge in November 1996, for leading 'hostile campaigns at home and abroad to foster division and hatred among Cameroonians' ${ }^{6}$ They equally challenge claims of Anglophone marginalisation, preferring to talk instead of 'self-marginalisation', and they invite Anglophones to consider themselves as fully-fledged Cameroonians with the same rights and responsibilities as Francophones (Nyamnjoh \& Rowlands 1998: 335). This has led to serious confrontations between the two camps and to mutual accusations of betrayal. But to most ordinary Anglophones it is simply hard to fathom how, just for a few appointments and sinecures, their elite can be so eager to serve as gatekeepers and scavengers for a government that denies them an identity and refuses to recognise their predicaments as a community (Nyamnjoh 1999).

Following the organisation of the AAC I in April 1993, attempts were made by certain members of the South West Chiefs' Conference (SWECC) and the South West Elite Association (SWELA), who were known to be closely allied

6 See The Herald, 2-3 December 1996, p. 1. 
with the regime in power, to dissociate the South West Province from the deliberations and resolutions of the AAC I and from the Buea Declaration. A meeting was held of a previously little-known North West Cultural and Development Association (NOCUDA) in Bamenda on 14 May 1993 to dissociate the North West Province from the AAC I by branding the latter as a South West concern. This meeting seems to have been organised by northwestern members of the CPDM, who again in 1994 would actively work against the holding of the AAC II in Bamenda in a bid 'to kill the Anglophone dream'?

In September 1993, nine representatives of the SWECC undertook a mission to Yaoundé to pledge their unswerving allegiance to President Biya. They told him that 'they were alarmed at the numerous demonstrations, blackmail, civil disobedience, rebellious attitudes and recurrent activities designed to destabilise the state and the government', and strongly condemned any attempt to partition Cameroon on the basis of Anglophone and Francophone cultures. They asked the head of state to transform the present ten provinces into ten autonomous provinces, and drew his attention to the fact that, after reunification, the South West Province had been discriminated against in the distribution of strategic posts, such as prime minister, vice-president and speaker of the national assembly all of which had been regularly occupied by North Westerners. $^{8}$

Following the military brutalities in the South West during the 1993 government anti-smuggling campaign, ${ }^{9}$ a split occurred in SWELA, which had been founded in 1991 to promote the socio-economic and cultural development of the province and combat its domination by the North West. ${ }^{10}$ The split gave birth to a pro-CPDM faction keen on maintaining close links with the Biya

7 See Cameroon Post, 20-27 April 1994, pp. 2-3; Cameroon Post (Special), 29 April 1 May, 1994, pp. 1-12; Cameroon Post, 29 June - 6 July 1994, pp. 6-7; The Herald, 29 April-1 May 1994, pp. 1-2; Cameroon Post, 29 June-6 July 1994, pp. 6-7; and The Messenger, 2 May 1994, pp. 1-2.

8 The Herald, 3-10 November 1993, p. 6. For the role of chieftaincy in the Anglophone struggles, see Konings 1999b.

9 Because of its proximity to the southeastern region of Nigeria, and because of the easy access offered by its sea and river ports to and from Nigeria, the South West Province has traditionally attracted informal, often illegal, commerce between Cameroonian and Nigerian traders (Niger-Thomas 2000). A significant amount of basic consumer items sold in Cameroon are smuggled from Nigeria, often with the complicity of customs at the borders. Prior to the anti-smuggling campaign, most car users in the South West Province had turned to much cheaper fuel smuggled from Nigeria, a development the Cameroonian authorities, in dire need of liquidity from the sales of its own oil especially following the crippling effect of the 'ghost town', could not condone.

10 For SWELA, see Nyamnjoh \& Rowlands 1998. 
regime and on showing strong anti-North West sentiments. The members of this group include older and younger CPDM barons, like Emmanuel Tabi Egbe, Peter Agbor Tabi, John Ebong Ngolle, Ephraim Inoni and Caven Nnoko Mbele (secretary-general), as well as important South West chiefs such as Mola Samuel Endeley and Nfon Victor Mukete. They are all opposed to a return to the federal state and champion the ten-state option, which would retain the present separation between the South West and North West Provinces, and thus safeguard the former's autonomy. ${ }^{11}$ By way of contrast, another faction of SWELA, with Martin Nkemngu of Lebialem Division as secretary-general, was more critical of government policies and tended to be allied to the opposition, notably the SDF. ${ }^{12}$ It advocated closer cooperation between the South West and North West elites as a necessary precondition for an effective representation of Anglophone interests. It strongly supported the Anglophone demand for a return to the federal state ${ }^{13}$ - a stance heavily criticised by the pro-CPDM faction that saw Nkemngu and the entire Lebialem Division as Grassfielders and therefore North Westerners in disguise. But in order to show the powerful nature of the pro-CPDM SWELA, Secretary-General Caven Nnoko Mbelle was appointed as government delegate for the Kumba Urban Council following the January 1996 municipal elections, while Martin Nkemngu, secretary-general of the pro-SCNC SWELA, was transferred from Buea where he was provincial head of the news agency known as CAMNEWS to Yaoundé as an ordinary member of staff with the official publisher, SOPECAM. ${ }^{14}$

Since 1994 a number of southwestern and northwestern chiefs and members of the CPDM have repeatedly condemned the call for an independent Southern Cameroons state, appealing to the head of state to employ every available means to defend the unitary state. ${ }^{15}$ For example, when the SCNC was engaged

11 See Weekly Post, No. 0069 and No. 0070 of November 1994 for a comprehensive account of the pro-CPDM SWELA's ten-state option.

12 Martin Nkemngu, for instance, publicly declared to be an active member of the SDF. He later served as SDF communication secretary and presenter of its weekly party political broadcast on state television. See Cameroon Post, 29 October-4 November 1996, pp. 1 and 9.

13 See Final Communiqué of the SWELA Annual General Assembly held in Menji in Lebialem division on 18 December 1993 which states: 'The General Assembly accordingly declares that the South West Elite Association is in favour of a constitution that guarantees provincial autonomy in a bi-cultural federation'. This declaration comes close to the position held by the Anglophone Standing Committee in its 1993 federal draft constitution. See The Messenger, 30 December 1993, p. 10.

14 For an idea on the 'war' of the SWELAs, see Weekly Post, 26 January-2 February 1995, pp. 1-2.

15 See Cameroon Post, 17-24 July 1995, pp. 1 and 3, for the case of the South West Province where 'Pro-CPDM Chiefs Bargain Destruction of SCNC' at a chiefs' conference. For a detailed report, see Konings 1999b. 
in a sensitisation tour throughout the Anglophone territory after its historic May-June 1995 mission to the United Nations (see Chapter 4), it was reported that:

The latest SCNC-CPDM clash of principles and ideas cropped up in Kumba in July 1995 when more than 400 chiefs met to condemn the 'secessionist' moves of the SCNC leaders accusing them of playing off divisive politics. Before the Kumba meeting, the president (Tatah Nganga Obie III) and the secretary-general (Dr Atem Ebako) of the South West Chiefs Conference signed a communiqué condemning the SCNC delegation. The Kumba meeting was therefore meant to reinforce that first communiqué. Earlier Prime Minister Simon Achidi Achu, who hails from the North West Province, had quickly organised a meeting in Bamenda to tell President Paul Biya that rumours circulating in government circles that he had sponsored the SCNC delegation to the United Nations were totally unfounded. Interestingly enough, all the anti-CPDM participants in the meeting were driven away from the Conference Centre, prompting them to sign a counter communiqué in which they called for a referendum as the only solution to the crisis.

Other interesting facts about the CPDM-organised anti-SCNC conferences are that while the South West chiefs, afraid of being dominated by North Westerners, reiterated their preferred ten-state option, the Achidi conference members merely condemned the SCNC 'secessionist' moves, falling short of proposing an alternative. $^{16}$

The SCNC, in turn, has repeatedly reacted in strong terms to the 'evil machinations' of Biya's allies among the Anglophone traditional and modern elite. For instance, on 28 January 1995, the SCNC reacted as follows:

The Council vehemently condemns the evil machinations concocted by the so-called South West Chiefs Conference and Nnoko Mbelle posing for SWELA, on the one hand, and by the North West CPDM barons and chiefs led by Minister Chongwain Nkwain, on the other, to create divisions among the peoples of Southern Cameroons. By engaging in such activities, they attempt to enhance their own selfish interests and to perpetuate the hegemony of La République du Cameroun over the Southern Cameroons. The Council calls upon the peoples of Southern Cameroons to ignore these charlatans and not to deviate from the ultimate goal of their struggle, which is the restoration of Southern Cameroons' autonomy. ${ }^{17}$

Paradoxically, the Anglophone problem has considerably enhanced the chances of Biya loyalists being appointed to government posts that used to be reserved for Francophones. Obviously, the decision to enhance the position of Anglophones in the state apparatus is designed to belie charges that they only

16 The Star Headlines, 21-28 July 1995, pp. 1 and 4.

17 Cameroon Post, 7-14 February 1995, p. 4. 
play second fiddle in the Francophone-dominated unitary state ${ }^{18}$ and simultaneously to attract new members of the Anglophone elite into the 'hegemonic alliance' (Bayart 1979). But Anglophones generally are not deceived by such cosmetic gestures at inclusion. They have always laughed sardonically at them when government officials and praise-singer journalists have bent over backwards to refer to the Anglophone prime minister as 'Premier Ministre et Chef du Gouvernement', precisely because everyone knows, the prime minister included, that in reality he is not the head of government and can take no major decisions.

In 1992 Simon Achidi Achu, a North Westerner, and Ephraim Inoni, a South Westerner, were appointed respectively as prime minister and deputy secretarygeneral in the Presidency of the Republic. Other highly-placed Anglophones, including Peter Abety, John Ebong Ngolle, John Niba Ngu, Francis Chongwain Nkwain, Peter Agbor Tabi and Samuel Ngeh Tamfu, may also expect to be members of the delegations that are regularly sent from Yaoundé to contest the claims of the leadership of the Anglophone movements and to defend the unitary state. It should, however, be noted that Biya's policy of allocating prestigious positions within the state apparatus to Anglophones has encouraged competition among these privileged allies (Nyamnjoh 1999), leading to debates as to who the real enemy of the Anglophone people is - Biya or the Anglophone elite? Hence, Churchill Monono's argument that:

No matter the prevailing goodwill, Biya's Anglophonisation strategy can only be effective if his Anglophone appointees understand their roles in helping him to solve the Anglophone problem within a national context. It is rather unfortunate that most of Biya's Anglophone appointees perceive their positions as rewards for their technocratic or managerial 'competence', 'skills', and hard work, or as marks of 'personal confidence' from the Head of State. Few of them perceive themselves as political agents of the President to help him redress the Anglophone problem within a national context (Monono 2000).

For the first six years of the democratisation process in the 1990s, the South West elite still felt they were underrepresented in the highest government

18 That he succeeds can be seen from the dramatic change in the discourse of every Anglophone appointed to high office. Thus for example, shortly after his appointment as prime minister in September 1996, Peter Musonge told the Anglophone community in Yaoundé to desist from self-marginalisation and to consider themselves fully-fledged Cameroonians with the same rights and responsibilities as Francophones. He urged them 'to do everything possible to overcome the feeling of marginalisation and built-in complexes', and to see in Biya's appointment of an Anglophone prime minister proof that 'the Anglophone community is part and parcel of the whole nation'. See Cameroon Tribune, 2 December 1996, p. 16; and The Herald, 2-3 December 1996, pp. 1 and 3. 
offices and constantly requested that a politician from their province succeed Achidi Achu as prime minister. ${ }^{19}$ So when a South Westerner, Peter Mafany Musonge, was appointed in September 1996 to take over from Achidi Achu as prime minister and more South Westerners were kept in key cabinet positions than North Westerners,$^{20}$ the South West people reportedly 'went wild with excitement and jubilation and loudly praised the head of state' for having at last listened to the cry of despair of South Westerners who for over 36 years had been 'confined to the periphery of national politics and socio-economic development' ${ }^{21}$ In the words of Musonge himself, this being 'the first time in our history as a united nation that a South Westerner has been appointed Prime Minister', South Westerners had 'to come together to galvanise the second political awakening in the South West Province', and to 'strengthen our position and bargaining power'. ${ }^{22}$ At his CPDM congress in December 1996, Paul Biya further strengthened the position of South Westerners by admitting more of them into the central committee of the party than North Westerners; and the 22-member political bureau formed after the congress included two South Westerners, John Ebong Ngolle and Dorothy Njeuma, and only one North Westerner, Samuel Ngeh Tamfu. ${ }^{23}$

19 For example, following the January 1996 municipal elections which, according to official results, Prime Minister Achidi Achu (North Westerner) lost in his home constituency of Santa, while Minister of Higher Education Peter Agbor Tabi (South Westerner) won in Mamfe, the latter did not conceal his ambition to take over from Achidi Achu as prime minister. See The Herald, 1-3 April 1996, pp. 1 and 3; The Herald, 11-14 April 1996, pp. 1 and 2 and Weekly Post, 5-11 June 1996, pp. 1 and 4. In March 1995 Churchill Ewumbue-Monono, a southwestern political analyst and journalist, not only predicted that the next prime minister would be an Anglophone and South Westerner, but even had the prescience to name Peter Mafany Musonge as the most likely successor: 'like Achidi Achu who left Bamenda to become Prime Minister, Musonge could also leave Limbe to the Star House'. See Cameroon Post, 24-30 September 1996, pp. 1 and 3.

20 See Cameroon Tribune, 20 September 1996, pp. 1-4 and 2 October 1996, pp. 8-9.

21 See 'Significance of P.M. Musonge's Appointment' by Kome Epule, a member of the South West elite, in The Star Headlines, 20 November 1996, p. 5.

22 For reports on the reaction by South Westerners to the appointment of 'a son of the soil' as prime minister and how, thanks to Paul Biya, 'the South West Smiles ... Again', and on the grandiose reception they offered Pater Mafany Musonge in Buea, Limbe and Yaoundé, see The Herald, 2-3 October 1996, pp. 1 and 3; 11-12 November 1996, pp. 1 and 3; 13-14 November 1996, pp. 1 and 3; 2-3 December 1996, pp. 1 and 3; The Star Headlines, 20 November 1996, pp. 1 and 3; Cameroon Tribune, 12 November 1996, pp. 1 and 7-10; 2 December 1996, p. 16 and Cameroon Post, 12-18 November 1996, pp. 1 and 3.

23 See Cameroon Tribune, 20 December 1996, pp. 4-5; and The Herald, 22-24 December 1996, p. 2. 
These developments were interpreted by the North West CPDM barons as evidence that they were indicted by the head of state for their failure to contain the SDF and radical Anglophones amongst them. The subsequent creation of a North West Development Association (NOWEDA) by Peter Abety, minister for special duties at the presidency, and of two chiefs' organisations, the North West Fons' Association (NOWEFA) and North West Fons' Conference (NOWEFCO), may be seen as attempts by these barons to retrieve lost advantages.

South West ascendancy in the state apparatus followed in the wake of the January 1996 constitution, ${ }^{24}$ which promised state protection for autochthonous minorities, and boosted South West identity. In the ongoing struggle for economic and political power, the southwestern allies of the Biya regime started demanding state protection for the 'autochthonous' South Westerners against the 'dominant' and 'exploitative' Grassfields 'settlers', 'strangers' or to use the Pidgin-English expression - cam-no-goes in their region. ${ }^{25}$ The South West pro-CPDM elite became alarmed when the North West-based opposition party, the SDF, won most key urban constituencies in their region during the municipal elections which, by no means accidentally, were held only a few days after the adoption of the new constitution. The South West governor, Oben Peter Ashu, blamed the settler population, which outnumbered the indigenes in most urban areas of the province, for the CPDM's poor performance in urban areas. ${ }^{26}$ Before the elections, Nfon Victor Mukete, the Bafaw paramount chief, who had in earlier elections insisted that North Westerners acquire and present resident permits before they could vote, was reported to have organised a gang of thugs to deny victory to an SDF opposition candidate, and to punish North Westerners for having supported the latter. His tendency to single out Grassfielders among the 'ethnic strangers' was due to the fact that he, like other members of the pro-CPDM South West elite and the administration, were inclined to perceive Grassfielders as the greatest threat among ethnic strangers to the CPDM's grip on power and South West interests, and had to be contained accordingly. And to do so effectively, even the issuance of residence permits had to be limited to CPDM militants

24 For a more elaborate discussion of the 1996 constitution, see Melone et al. 1996; Konings \& Nyamnjoh 2000 and Geschiere \& Nyamnjoh 2000.

25 This appeal to the state was often accompanied by threats of 'ethnic cleansing' and 'removal of strangers' who in many cases were second or third-generation descendants of migrants. See Konings 2001b. 'Cam-no-go' literally means a visitor who refuses to leave even when he or she is no longer wanted. But it also refers to a persistent skin affliction that makes the body constantly itch. So the Grassfielders are not only unwanted visitors, they also cause great discomfort.

26 The Herald, 29-30 January 1996, p. 3. 
among Grassfields migrants. ${ }^{27}$ This move provoked protests and vehement condemnation in Kumba, Buea, Limbe and all over the South West by Grassfielders who felt stripped of their citizenship

The above sentiments were subsequently hailed by N.N. Mbile, one of the oldest and most experienced politicians in the South West Province (see Chapter 2) who had been appointed chairman of the CDC in the 1990s for his services to the regime in power, at a joint conference of the South West chiefs and elites in July 1999, and other traditional leaders were urged to emulate Chief Mukete in particular. ${ }^{28}$

Immediately after the January 1996 elections, the government provided the requested protection by appointing indigenous CPDM leaders as urban delegates in the municipalities won by the SDF. Undoubtedly, the regime rendered assistance after the municipal elections to the emerging Grand SAWA Movement, ${ }^{29}$ an alignment of the ethnically-related coastal elite in the South West Province and neighbouring Francophone Littoral Province on the basis of common feelings of exploitation and domination by Grassfields settlers (Tatah Mentan 1996; Wang Sonnè 1997; Yenshu 1998; Geschiere \& Nyamnjoh 2000; Konings 2001b). This alignment came into being after the indigenous SAWA elite in Douala had staged government-condoned demonstrations against the Francophone Grassfielders, the Bamileke, who alone accounted for 70 per cent of the Douala population, and who had provided for only one indigenous mayor in the five municipal councils where the SDF had won. ${ }^{30}$ The emergence of the Grand SAWA Movement signified an important victory for the government in its persistent efforts to tempt the South West elite away from Anglophone solidarity. Evidently, this new movement had a devastating effect on Anglophone identity with the Francophone-Anglophone divide becoming cross-cut by alliances that opposed the coastal people, the Grand SAWA, to the Grassfields

27 Another Kumba-based elite who tended to blame settlers for most of the economic, political and social problems in the South West Province was Chief Dr Atem Ebako, the then secretary-general of the SWECC. See The Herald, 19-20 March 1997, p. 1 and Geschiere \& Nyamnjoh 2000.

28 For a detailed report on the conference which was held at the University of Buea on 17 July 1999, see The Herald, 21 July 1999, pp. 1 and 3-4. See also Mbile 2000.

29 The term Sawa was originally employed by the native Douala to refer to themselves as coastal people. It has subsequently been extended to embrace related ethnic groups in the coastal areas of the Littoral and South West Provinces. Of late, even ethnic groups in the forest areas of the Littoral and South West Provinces have come to identify with the SAWA. See Yenshu 1998.

30 The SAWA demonstrators displayed placards with the following among other messages: 'Yes to Democracy, No to Hegemony', 'No Democracy without Protection for Minorities and Indigenes', 'A Majority based on Ethnic Votes is not a Sign of Democracy but that of Expansionism'. See Wang Sonnè 1997. 
people, the so-called Grand West. The alliance between the Francophone and Anglophone Grassfielders constituted the backbone of the major opposition party, the SDF.

To those who sought protection as minorities, the price to pay would increasingly be stated in no uncertain terms: 'Vote CPDM'. That is exactly what the SAWA elite has been telling the local population. In return, they have been highly rewarded for their efforts, gaining access to key positions in the state apparatus that were previously occupied by North Westerners. In fact, following his appointment as prime minister in September 1996, Peter Mafany Musonge and the pro-CPDM SAWA elite did not relent in their invitation to all coastal people to throw their weight behind President Biya and the CPDM. As Musonge put it during a reception in Buea following his appointment: 'President Biya has scratched our back, and we shall certainly scratch the Head of State's back thoroughly when the time comes', meaning that the SAWA should, together with him, resolve to manifest their total support and allegiance to the president who appointed him. ${ }^{3}$

Like Musonge, other members of the South West elite have regularly appealed to the local population to support Biya and the CPDM. According to the South West Governor Oben Peter Ashu, the South West was ready to go to war to keep Biya, Musonge and the CPDM in power. On the eve of the 1997 parliamentary elections, he issued a war cry that The Herald captured as follows:

We are ready to fight to the last man to maintain our son as prime minister. This is the time for all South-Westerners to be ready to die or survive [...] We have the Prime Minister and what we need now is only satisfaction and social amenities [...] Referring to North-Westerners resident in the South West, ... the governor said the South West was satisfied with what it had and 'anyone who is not here to safeguard the interests of the province should immediately pack back to his home' ${ }^{32}$

On 21 March 1997, the Secretary-General of the South West Chiefs' Conference (SWECC), Chief Dr Atem Ebako, equally called upon South Westerners to support the ruling party in the forthcoming parliamentary elections:

31 See Cameroon Post, 12-18 November 1996, pp. 1 and 3; The Herald, 11-12 November 1996, pp. 1 and 3; and The Star Headlines, 20 November 1996, pp. 1-7. For a critical commentary on the 'politics of back scratching' which former Prime Minister Simon Achidi Achu and his successor, Prime Minister Peter Mafany Musonge, sought to promote in their regions and elsewhere in appreciation of appointments by Biya, see Rotcod Gobata in Cameroon Post, 26 November-2 December 1996, p. 7.

32 The Herald, 6-8 June 1997, p. 1. 
Our communities, especially those in Fako and Meme Divisions, are swarmed by Cameroonians from other places and provinces ... It is possible to have Cameroonians who are not indigenous in the South West Province to become representatives of South Westerners ... at local councils, parliament, and government. This aspect of the evolution of the political life of the South West Province, which became very obvious after the 21 January 1996 municipal elections, is most repulsive, resentful, indignant, and pre-occupying.

Our choice is clear as we stated in the General Assembly Meeting in Kumba on 8 March 1997. We called on all South Westerners and all their friends of voting age without exception to register and vote massively for the candidates of the CPDM party of President Paul Biya at the forthcoming parliamentary elections. ${ }^{33}$

Like Nfon Victor Mukete during the 1996 municipal elections, Governor Oben Peter Ashu was reported to be issuing residence permits to settlers before they could vote during the 1997 parliamentary elections, a move that was clearly intended to favour the party in power. ${ }^{34}$ Following the overwhelming South West support for his candidacy during the 1997 presidential elections, Biya reappointed Musonge as prime minister in a subsequent cabinet reshuffle.

One has to be extremely careful, however, in asserting that Biya's divisive tactics have been successful in deconstructing the Anglophone identity. After Fon Njifua of Fontem declared at the joint conference of chiefs and elites in Buea in July 1999 that no true South Westerner sympathised with the SCNC, ${ }^{35}$ his declaration was immediately contested by one of his colleagues, Chief Esong Joseph Ntongwe, the new secretary-general of the SWECC. The latter cautioned that the Anglophone problem was a time-bomb that could only be defused if handed diligently, that is, by granting 'equal opportunities to all Cameroonians without any form of discrimination to participate and benefit of the proceeds of the state'. ${ }^{36}$ In a story headlined 'South West CPDM Member of Parliament Embarrasses Government on the Anglophone Problem', The Herald reported that Hon. Nzoubotame, a CPDM parliamentarian from Kupe Muanenguba, shocked his 'stalemates of the New Deal regime' by stating:

It is sheer dishonesty for anybody not to recognise the existence of an Anglophone problem in this country... Time has come to leave party loyalty and discipline aside and honestly and effectively solve the problem once and for all. ${ }^{37}$

33 See 'South West Chiefs' Conference on the Plight of South West Province' in The Pilot Magazine, May 1997, p. 8.

34 Little wonder that settlers felt disenfranchised by this move. See Yenshu 1998.

35 The Herald, 21 July 1999, p. 3.

36 The Post, 18 August 2000, p. 2.

37 The Herald, 22 April 2000, p. 1. 
Following his presentation of a memorandum to the UN General-Secretary Kofi Annan during the latter's visit to Cameroon in May 2000 (see Chapter 4), the newly elected Secretary-General Emmanuel Efase Lyonga of the revived SWELA was attacked by some members. They strongly contested his claim to have spoken on their behalf when he stated in the memorandum that the rights of minorities and autochthonous people were being catered for in Cameroon and that the decentralisation of the country into ten autonomous provinces as laid down in the 1996 constitution was 'in line with the aspirations of our people'. ${ }^{38}$

Remarkably, persistent security reports have attested to the presence of proSCNC Anglophone officials within the CPDM. One SCNC activist argued that the Anglophone gatekeepers of the regime 'support the SCNC with their hearts in private, but pretend to speak against it in public in order to protect their positions' ${ }^{39}$ There is empirical evidence to back this argument. In 1995 an SCNC appeal was made to the Southern Cameroonian population to help defray the costs of an Elad-led delegation to the United Nations. At an SCNC meeting in Bamenda, Foncha, who had been assigned to contact the Anglophone cabinet members, informed those present that these ministers had agreed in principle to contribute, their only quarrel being the amount of money imposed upon them. Similarly, when the Biya government decided to send a high-powered delegation to the South West Province to convince the local population of the need to privatise the Cameroon Development Corporation (CDC), a huge agro-industrial parastatal in the area (see Chapter 7), Anglophone ministers informed the SCNC of this mission and urged it to put up fierce resistance (Jua 2001).

\section{The establishment of direct and indirect control over the mass media}

One of the instruments that the Francophone-dominated state has relied on to implement its various strategies to disempower Anglophones has been the media. By seeking total ownership and control of the broadcast media while using draconian laws to stifle the private press, the state has over the years stunted Anglophone freedom, weakened solidarity among Anglophones and dealt their sense of identity a crippling blow. Government media policies and practices and their effect on Anglophones prior to 1990 have been well documented (cf. Nyamnjoh 1989 and 1990), so too has the particularly difficult

38 The Post, 26 June 2000, p. 2.

39 The Post, 7 February 2000, p. 3. 
legal environment in which the private press has operated since 1990 (cf. Nyamnjoh 1996b and c). In this section, we focus on how the Biya government has employed the state media, and broadcasting in particular, to deny Anglophone identity and solidarity, while tacitly encouraging the rise and proliferation of the ethnic and regional print media.

\section{Cameroon Radio and Television (CRTV) and Anglophone identity}

With the launching of the SDF in 1990, Anglophone journalists in the official media, in general, tended to distance themselves from the sort of proestablishment journalism defined by government and largely taken for granted by their Francophone colleagues. The history of turbulence in the official media was principally the history of government attempts to streamline Anglophone journalists. The launching of the SDF led to a witch-hunt amongst Anglophone journalists in CRTV, whom management identified with the new illegal party. The witch-hunt was understandable, for while Zacharie Ngniman, Antoine-Marie Ngono and other Francophone journalists presented an unsigned and undated communiqué from Minister Henri Bandolo about the killing of six Anglophones during the launch of the SDF in Bamenda in May 1990 as if it were verified information, Julius Wamey, on his part, insisted that his broadcast was the government's version of events. ${ }^{40}$ Relations between CRTV authorities and critical Anglophone journalists only worsened following the introduction of multipartyism, leading to claims in the private press of an antiAnglophone campaign mounted by the government and CRTV management. Much of this has been well documented (cf. Nyamnjoh 1996b) but here are a few examples.

The Cameroon Post ${ }^{41}$ reported a meeting held by the minister of information and culture in the first week of June 1991 with CRTV journalists during which he implicitly accused English-language programmes of being sympathetic to the opposition. Specifically cited were 'Luncheon Date' - later on modified drastically on the minister's orders, 'News Focus', the '7.30 p.m. News' and 'Cameroon Calling' from which Anembom Munjo, Wain Paul Ngam, Asonglefac Nkemleke and Julius Wamey were subsequently suspended. The minister also attacked TV news Editor-in-Chief Eric Chinje 'for reporting the resignation of CPDM Wouri Section President Jean Jacques Ekindi without

40 Until CRTV management transferred critical Anglophone journalists away from the newsroom or increasingly sanctioned them for not following 'handed-down' instructions on what to report and how, CRTV newscasts in English were more appreciated even by Francophones. Some evidence can be found in a survey that a Francophone journal, Challenge Hebdo, carried out among its readers in 1991. See Challenge Hebdo, 26 December 1991, pp. 7-10.

41 Cameroon Post, 6-13 June 1991, p. 1. 
announcing the non-resignation of Mifi Section President Joseph K. Tanyi'. The minister implied that this was part of the Anglophone journalists' attempt to sabotage the CPDM government. The suspensions were interpreted by the journalists as "part of a campaign launched by the Information and Culture Minister and CRTV General Manager Mendo Ze to stem the tide of Anglophone journalists' objectivity on CRTV'. ${ }^{42}$ The minister insisted on the need for CRTV journalists to respect the corporation's editorial policy, a euphemism for asking all journalists to see things the government's way. Julius Wamey was accused of having falsely claimed during a CRTV news flash that the South West chiefs' meeting in Kumba had called for a national conference, and that students marching in Bamenda had done the same. The governor of the North West Province, in a telex to the Ministry of Territorial Administration (MINAT), was reported to have wondered 'why government media organs are being used by journalists who are partisan to the SDF'.

In a confidential letter to the general manager of CRTV, Prime Minister Sadou Hayatou was $\operatorname{said}^{44}$ to have called for sanctions against Anglophone journalists who were using the official media to 'try the government'. The prime minister was reported to have accused among others, 'Cameroon Calling' and the English news, of having 'more and more exhibited reckless abandon ... in their analysis which have of late seemed like an arraignment of government action'. In his letter he complained that 'newscasters on radio and television have tended to express their personal standpoints as if they were those of government'. He concluded by instructing the general manager to 'verify this situation and where necessary address a severe warning to such personnel who should not turn a public service into a private media with a tendency to teleguide government action'.

While some Anglophone journalists in the public media - their disillusionment notwithstanding - identified with the PR role expected of them by government, others opted either to leave the system entirely (e.g. Boh Herbert, ${ }^{45}$ Charlie Ndichia, ${ }^{46}$ Eric Chinje, ${ }^{47}$ Victor Epie Ngome, Orlando Bama, Larry Eyong-Echaw, Ben Bongang and Julius Wamey) or to distance themselves

${ }^{42}$ Ibid.

43 Ibid.

44 See Cameroon Post, 30 July - 6 August 1991, p. 3.

45 In an interview with Challenge Hebdo, he stated his reasons for leaving CRTV and resigning from the civil service. See Challenge Hebdo, 31 October-6 November 1991, pp. 14-15.

46 For more on Charlie Ndichia and his problems as a journalist in Cameroon and in CRTV, see Le Messager (Special Edition), 25 April 1991. p. 12 and 23 January 1991, p. 11.

47 For Eric Chinje's account of why and how he left CRTV, see Fondation FriedrichEbert 1993. 
from official rhetoric whenever they could (e.g. Ebssiy Ngum, Wain Paul Ngam and Asonglefac Nkemleke). According to The Diasporan, of the nearly 50 reporters and announcers who started or joined television in its first three years of existence, 27 (21 of whom were Anglophones) had, by April 1994, 'departed in bitterness and disillusionment to seek better climes'. ${ }^{48}$ Those who opted for government PR journalism, claimed that all the government and its acolytes did was in the best interests of Anglophones and Cameroon in general, and that the SDF and Anglophone movements were void of true patriots and motivated only by selfish, regional or ethnic self-interests. The CRTV management would encourage such pro-government journalists with appointments to key positions, and eventually, the impression would be created that the critical journalists were from the North West Province while their proestablishment counterparts were from the South West Province. Selective appointments of South West journalists to strategic positions would further drive this message home.

However, the critical journalists were convinced that the 'radical' opposition and 'extremist' pressure groups they supported stood for 'the truth' and the best interests of Anglophones and of Cameroon, and that the government and its acolytes were dissemblers motivated by selfish ambition, greed for power and other self-centred pursuits. Many Anglophone journalists in CRTV who rapidly distanced themselves from their role as government spokesmen or mouthpieces following the launching of the SDF thus rechannelled their energies into the service of the marginalised Anglophone community. But using the official media to articulate societal problems and aspirations met with stiff resistance from the authorities. The turbulent history of critical English language CRTV programmes such as 'Cameroon Calling' (formally 'Cameroon Report'), 'Minute by Minute' and 'Luncheon Date' are sufficient testimony of government discomfort with Anglophone critical-mindedness and a purportedly heightened sense of public accountability (Nyamnjoh 1996b).

In June 1992, members of the 'Cameroon Calling' production team (Benn Bongang, Zac Angafor and Akwanka Joe Ndifor) amongst others, were appointed and transferred in various capacities to provincial CRTV stations. This move was seen by those concerned as a calculated attempt by government to kill a programme that had never ceased to embarrass it, especially following the decision by CRTV Deputy General Manager Emmanuel Nguiamba

48 See The Diasporan, 14 April 1995, which devotes its front and centre pages to television in Cameroon, 'a revolution that ate its children'. The articles or testimonies are by Eric Chinje, Julius Wamey, Melissa Nambangi and Orlando Bama, all of whom are former CRTV journalists living and/or studying in the United States. The Diasporan is based in the United States and has Julius Wamey as editor-inchief. 
Nloutsiri to subject 'Cameroon Calling' to unprecedented administrative censorship. ${ }^{49}$ The latter blamed the crew of 'Cameroon Calling' for disrespecting numerous warnings from the hierarchy and for continuing to use the programme 'to put the government on trial'. He accused some of the journalists of not hesitating to question the integrity of the highest authorities in the state, but often without any proof to back their allegations. Others, he said, did not hesitate to incite the population to revolt and by so doing, were endangering national unity. He called on them to understand that the CRTV was a public utility and a privileged instrument for the propagation of government activities.

To put an end to 'ce laisser-aller préjudiciable à l'action des pouvoirs publics et à la stabilité des institutions', the deputy general manager prescribed, inter alia, that 'Cameroon Calling' be henceforth taped and no longer transmitted live as was the case before. The pre-recorded programme was to be submitted for the critical appreciation of either the director of information, his deputy or the editor-in-chief for features. 'The certified approval of one of these authorities is necessary before the programme can be broadcast'. Finally, the above-named gatekeepers were expected to issue a weekly report on the effective implementation of this prescription.

On February 2 1994, the general manager of CRTV took decision No. 00012 following 'instructions from above' to send Tamfu Hanson Ghandi, Metuge Alfred Sone and Viban Napoleon Bongadzem to the Ministry of Communication. The crime of these journalists was the non-respect of CRTV editorial policy. ${ }^{50}$

Also in February 1994, Angèle Tabe Ndie was sent to the ministry because of 'indiscipline et légèreté dans le traitement de l'information' ${ }^{51}$ She had been accused, in October 1992, of having 'attended the press conference of the Minister of Communication on the 26th of October 1992, without having been assigned by CRTV Editorial Desk' and for having 'asked questions on behalf of the corporation, questions that seemed to placed [sic] the corporation on a defence'. ${ }^{52}$ Also queried in connection with that same press conference were

49 See Note of Service, No. 00060 of 8 June 1992, reproduced in Le Messager, 18 June 1992.

so See, for example, the letter from Deputy Editor-in-Chief of Information (radio) Chris Enoh Oben, dated 31 January 1994, to the CRTV general manager, accusing Tamfu Hanson Ghandi of clandestine publicity for Cameroon Post, a newspaper 'which is not only notoriously anti-government, but also an officious propaganda organ of the SDF party'. Tamfu Hanson Ghandi, he claimed, 'has the habit of selling newsroom material (e.g. GCE results) to private newspapers' for which he writes regularly using a pen-name.

${ }_{51}$ See decision no. 00027/CRTV/DG/DAF/SDPel, 25 February 1994.

52 See confidential query no. 00011/CRTV/DG/DPACRA of 28 October 1992, signed for the general manager by Peter Essoka. 
Wain Paul Ngam and Orlando Bama. Wain Paul Ngam was accused of tarnishing the image of CRTV after he suggested in his question that the minister's report on the burning to death of Mr Gideon Manko Ngum, the district officer of Muyuka, and Alhadji Tita Fomukong, the leader of the Cameroon National Party (CNP), by opposition partisans was biased. Orlando Bama, on his part, was guilty of wanting to know why Biya had been shown 'unkempt' on television despite the presence of competent image-makers. On 12 October 1992, James Achanyi Fontem was suspended for broadcasting election results that had not been issued by MINAT. Other victims of similar decisions included Victor Epie Ngome who left Cameroon to join the BBC for six months, and Francis Niba who was recalled to the ministry from Bertoua for professional indiscretion.

In general, Anglophones feel CRTV does not cater to their interests. According to Philip Ndi, ${ }^{53}$ this is because 'there is nobody who actually represents the Anglophones at CRTV', and 'decisions are taken arbitrarily and nobody raises an eye brow'. He argues that 'many decisions are taken not only to frustrate Anglophone journalists but to minimise and discredit their efforts'. Even those Anglophones who appear to hold high positions and have become slaves in the service of the institution and the state are rarely treated with dignity or given the recognition they deserve. The following excerpts from a eulogy by Victor Epie Ngome on the death in May 2000 of Luke Ananga, one of the pillars of pro-establishment Anglophone journalism at CRTV, illustrates this adequately:

...When he [Luke Ananga] analysed the President's speeches, he left you in no doubt that he had been privy to their drafting. He bubbled with conviction whenever he appeared on TV to pontificate about some new bridge the government had built where there was no stream. He talked big and looked it. And why not? He held what should be the most powerful post in any news organisation. So how could Ananga be a stress case? [....]

As Director of Information he reigned while his subjects ruled. According to inside sources, he was hardly ever part of the teams that accompanied the GM on long trips to Europe to reflect on news policy. It was his subordinates that went. Their opinions, not his, were sought, and they knew the inner workings of things far better than he. And so a swaggering Director chairing a meeting of more informed and more powerful subs cut a rather piteous and ludicrous picture. He was cordoned by a ring of young, junior collaborators who, because of their privileged ethnic and other extra-professional relations with the boss, could laugh him off when he spoke with a lot of ardour about the shadow while they knew the substance. In a word Luke lived and worked in emasculating circumstances and died betrayed by a system for which he had sacrificed everything including his principles and his personality.

53 The Herald, 13-20 January 1993, p. 4. 
Someone said what finished Luke off was the fact that CRTV's GM, Mendo Ze, could not be bothered to visit him even once during all the time he spent in the clinic a bare five hundred meters from Mendo Ze's residence. Strange that a corporation whose management has so often flaunted its overflowing charity let its own Inspector-General die virtually unattended in an obscure clinic. What would it have taken for him to be flown abroad for treatment? Should he have changed his initials to $\mathrm{CN}$, AMN, SNN, ET, JLN etc. to qualify?

A death, even that of a politically vocal person like Luke, should not be politicised gratuitously. Still, one cannot discount the probability that his physical death had a not-too-remote political component. I remember Luke's overflowing enthusiasm in a chat during AAC I in Buea. 'This is the winning ticket, doc', he said. 'This is where I belong'. Ananga certainly knew on which side his political bread was buttered but he also knew where his navel was buried. There was enough around him to keep him reminded that, however hard he tried, he did not, could not, belong to a family which even segregates the dogs that would eat of the crumbs falling off its children's table. Luke was unmistakably caught in the grip of the Anglophone lovehate predicament. They keep you forcibly in the nation but kill the nation in you. And you are not allowed even to mourn. So Ananga never sang dirges like Peter Essoka or (you name the rest) ..., but Cameroon had died in him, as indeed in most others.

Close acquaintances say Luke, in his last days, was not only bitter but desperate to 'prove to them' (whoever he meant) that he had some professional mettle. He started this talking-heads show on TV, for which he virtually went cap-in-hand before a secretary could deign to give him so much as a recording tape. As Inspector-General, he whined and rattled around in an old jalopy he inherited from Eric Chinje about a decade ago, and ran it thanks to fuel 'chipped in' by friends. 'They'll use you, and then kick you in the teeth', we often said of the system. Luke had certainly not expected it to get to him, but it did in most telling way. ${ }^{54}$

As an institution, CRTV has seldom been comfortable reporting the truth about any Anglophone movement, initiative or programme of action. An example of CRTV's unprofessional journalism in this connection is that of the 3 p.m. radio news on 27 April 1994 concerning AAC II. An announcement was made to the effect that the AAC II scheduled to be held in Bamenda from 29 April to 1 May had been postponed by the convenors. It was purported to have been signed by Dr Simon Munzu, Dr Carlson Anyangwe and Barrister Sam Ekontang Elad, a claim the three refuted. AAC spokesman, Dr Simon Munzu, prepared a disclaimer for broadcast by CRTV but this was rejected. CRTV was even unable to provide Dr Munzu with a copy of the announcement alleged to have been signed by him and his colleagues. ${ }^{55}$

Anglophones are of the impression that CRTV is there not so much to respond to their aspirations as to stifle initiative and any sense of identity in them. The decision to construct the FM transmitter for the South West Province

54 Victor Epie Ngome's eulogy for Luke Ananga, Scncforum, 9 May 2001.

55 For more details, see Cameroon Post, 29 April-1 May 1994, p. 2. 
in Douala was criticised by Anglophone interest groups (e.g. SWELA) and by the media, and taken as further proof of the government's negative position towards Anglophones. To some Anglophones, the Francophone authorities were so concerned with the possibility of oil in Victoria (Limbe) that they feared what might happen if Buea, given the prevailing trend of sentiments among critical Anglophone leaders and the public, were to be cut off from the rest of Cameroon and made capital of a seceding Southern Cameroons. Many people thought that the government wanted to be in control of access to radio technology and to be able to cut transmission should the need arise. ${ }^{56}$ This sentiment was later confirmed in December 1999 when the government swiftly arrested and detained Anglophone activists who raided and took over Radio Buea to declare independence for Southern Cameroons. Indeed, Anglophones are so suspicious of government and its designs that their first instinct is always to disbelieve that the government - which one of them describes as 'traditionally cocky, arrogant, lethargic and extremely callous ${ }^{57}$ - could be acting in good faith.

To Anglophones, it is clear from the content and language of programmes that television is predominantly for Francophones. French is the dominant language ${ }^{58}$ and French interests seem not only more important than those of the English-speaking community but are even more relevant than Cameroonian concerns and priorities. ${ }^{59}$ Quite regularly newscasts on CRTV are moved from their normal time slots to make way for the transmission of French football encounters. Rarely if ever has an English league match forced the rescheduling

${ }^{56}$ For the FM affair, see The Herald, 3-5 January 1994, p. 3 and Cameroon Post, 24 November-1 December 1993, p. 13.

57 See Cameroon Post, 27-30 May 1991, p. 6.

58 Complaints like the following by Dr Zama Kimbi Ndefru III are frequent in the Anglophone press and are shared by the entire Anglophone community:

The English-speaking viewers seem to be placed on a disadvantage even though entertainment programmes like Starcky and Hutch, Arnold and Willie, Colombo, Santa Barbara and Lucky Luke were originally in English. Taxes aside if the rights of all Cameroonians as citizens of this country mean anything, a second channel should be an unquestionable right. The two cultures have to co-exist on equal basis. See Cameroon Post, 14-21 April 1990, p. 2.

59 Eric Chinje recalls that during his years as editor-in-chief for TV news, there was a strong Francophone lobby, the membership of which ranged from a team of police investigators 'demanding to know why there was so much English on television' to the French ambassador who claimed that Eric Chinje was not a friend of France because Anglophones on TV 'were outperforming the Francophones'. See The Diasporan, 14 April 1995, p. 10. 
of a French news programme, and it is not even often that local matches or Cameroon's own international encounters are televised. ${ }^{60}$

Faced with such resistance, critical Anglophone journalists in the official media, some of them under pseudonyms, were able - thanks to the December 1990 communications law - to use the private English-language newspapers to highlight Anglophone problems, concerns and aspirations on the national political, cultural and economic agendas. Together with their counterparts in the critical English-language press, the liberation journalists of the official media were eager to expose the contradictions and inconsistencies in the policies and actions of the Cameroonian leadership. They argued that until the government started addressing the problems of the Anglophone minority in Cameroon, it would remain an obstacle to the country's economic progress and social justice. They criticised the rigid government suppression of contending social forces, especially those of Anglophone origin. They blame most of Cameroon's current socio-political and economic crises on the lack of accountability of successive Francophone-dominated governments, and present the Anglophone and the selflessness in public service in 'the good old days' of Southern Cameroons as the model. They identified with and were proud of the achievements of the Anglo-Saxon culture worldwide. Theirs, the Anglo-Saxon culture, 'has been tested and its validity adequately proved', and all Anglophones must take advantage of this identity 'rather than seeking to be Francophones only to wind up ridiculous cultural mulattos to be jeered at and patronised' ${ }^{61}$ And in this endeavour, their heroics received commendation from the Cameroon Association of English-Speaking Journalists (CAMASEJ) ${ }^{62}$

However, the rising tide of the politics of belonging, the failure of the opposition to make a marked difference and the weakening of the SCNC leadership have combined with the arrogance and confidence of those in power to silence many a once-critical CRTV journalist. Many have left and of those who have stayed on, most have chosen to conform. Once again, the policy of divide-and-rule has largely triumphed, and 'Anglophoneness' has ended up as the loser, even if only in the short term.

\section{The print media and Anglophone identity}

If in the first three years of the current democratic process a consensus on the Anglophone problem in the Anglophone press could be seen, this is much less the case today. The increased importance of regional and ethnic politics has indeed been matched by a redefinition of editorial policy on the part of some

See La Nouvelle Expression, No. 15, March 1993, p. 14

61 Cameroon Post, 27-30 May 1991, p. 6.

${ }^{62}$ See Le Messager, 28 February 1992, p. 10. 
existing papers and by the creation of new mouthpieces concerned with ethnic interests. Papers such as The Weekly Post, The Star Headlines and The Oracle have been created to focus on regional issues of interest to the South West Province and SWELA, and to highlight opposition to the Grassfielders (both the 'settlers' in the diaspora and those still in their North West and Western Provinces of origin). With the advent of the Grand SAWA Movement, they have now extended their interests to include what the movement stands for in general. Newer papers such as Elimbi, Muendi, The Beacon and Fako International (Mendi me Fako) have been created to focus more specifically on the political ambitions of the SAWA elite in the Littoral and South West Provinces, and to oppose Grassfields hegemony as a matter of policy. Since 1996, little has escaped criticism or comment by this press, including intertribal wars in the North West,${ }^{63}$ using them as an opportunity to deride the warmongering nature of Grassfielders and their penchant for fighting over land. During elections, the press sought through the rhetoric of ethnic cleansing to solve problems of political representation, and to encourage a widespread antagonism towards 'strangers', denouncing them as parasites and 'traitors in the house' (Collectif 'Changer le Cameroun' 1992; Eboussi Boulaga 1997b; Jua 1997). They sought to achieve, through a language of ethnicity and difference, the necessary level of fear that any kind of mixing with 'dubious settlers' would in the end be damaging to the minority interests.

As Wang Sonnè notes, the first issue of Elimbi on 26 March 1996 coincided with the launching of the SAWA Movement. Initially a bi-monthly, Elimbi became a weekly in November 1996 as the politics of belonging heated up. It described itself as a regional newspaper that targeted the people of the coast, paying attention in particular to the activities and news of the coastal elite. But Elimbi's most striking feature was 'the production and dissemination of ideas hostile to the Francophone Grassfielders, the Bamileke'. In this connection, Elimbi presented the Bamileke as a catalogue of weaknesses (porteur de tous les défauts), among which were stereotypes of the Bamileke as: 'sale, voleur, malin, rusé, trompeur, désordonné, sectariste, hégémonique'. In February 1997 on the eve of the March legislative elections, the proprietor of Elimbi, John Mandengué Epée, a native Douala businessman who a couple of years previously had initiated a libel case that ended in the imprisonment of Paddy Mbawa of Cameroon Post, launched a monthly publication entitled Muendi, with the mission of further defending SAWA identity and intensifying the antiBamileke feeling in Douala (Wang Sonnè 1997: 188-89).

The Grassfielders used the private press to fight back. In a similar manner, existing papers redefined their editorial focus, while new ethnic or regional

63 For these inter-tribal wars in the North West, see, for instance, Simo 1997. 
papers sprung up. The Bamileke and North West elite used established papers, most of which they owned and/or controlled, to riposte the attack by the SAWA press, interpreting the January 1996 constitutional changes as an impediment to the democratic process. The sheer volume of diatribes, commentaries, opinion and reports related to autochthony and allochthony in Grassfields newspapers such as La Nouvelle Expression, Le Messager, The Post and The Herald were an indication of how absorbing the politics of belonging had become since 1996, with equally blatantly ethnic papers like Ouest Echo and Nde Echo leading the way. Paradoxically, although about belonging, the Anglophone problem in Cameroon is being drowned by a press and government obsessed with a different kind of belonging.

In this connection, it would appear that even the South West would find it hard to remain united if the settlers from the Grassfields were to be chased out for good. For Governor Oben Peter Ashu to defend Prime Minister Musonge, as we have noted above, does not imply that the governor, as a Banyang from Manyu Division, is in total agreement with the Bakweri ethnic group of the prime minister. The politics of autochthony allows for multiple differences along regional, ethnic, tribal and clan lines such that one could agree and act together with others at a macro level but still be violently different at the micro level. Thus the very Oben Peter Ashu who defends Musonge at the macro level complains at the micro level of inter-ethnic or inter-divisional relations that the Bayang lost out to the Bakweri when the prime minister was appointed from among the Bakweri instead of from the Bayang. This is how The Herald reported his reaction to Musonge's appointment as prime minister in 1996:

South West Governor, Peter Oben Ashu, has lashed out at some Bakweri for making the appointment of Prime Minister Peter Mafany Musonge look like a 'Bakweri affair'. The Bayang, the governor said, were 'still licking their wounds after they lost out to the Bakweri, while Ndian, Lebialem, etc are grumbling'.

The governor warned at a second preparatory meeting for the Prime Minister's reception in Buea on October 9, that he was going to give the reception a 'provincial' rather than tribal dimension. He warned that all motions of support should be void of any tribal connotations and "no such things as the roads to Mamfe or Buea are bad'. 'We should be very careful not to give the impression that the Prime Minister is a Bakweri Prime Minister', he warned. [....]

It would be recalled that Peter Agbor Tabi, Higher Education Minister, a Bayang like Oben Ashu, made his lobby for the post of prime minister public knowledge. ${ }^{64}$

In fact, the Bayang, whose division is less developed and who have had to migrate to Meme and Fako Divisions, see themselves as marginalised and despised by the indigenes of these other divisions. According to a report in the

${ }^{64}$ The Herald, 18-20 October 1996, p. 1. 
Weekly Post ${ }^{65}$ a paper owned and managed by a Bayang, some Bayang complained of being 'put in the cold' when it came to awarding contracts in Meme and Fako Divisions. 'It is an open secret that contracts are not awarded to people of Manyu origin', the report claimed. 'We are told bluntly that we should go to councils in our own division and tender for contracts even though we live in these divisions (Fako and Meme) and pay our taxes here', one contractor revealed. 'In the Limbe Urban Council, the situation has always been one of hostility towards us. At a time when a Metta man [a migrant from the North West Province] was one of the Mayors, the natives were so vocal in calling only for the removal of three Manyu people holding the offices of Stores Accountant, Chief Clerk and Market Master. Today all the three have been removed and the office of Market Master handed to a Metta man. And we all know where the Metta votes would go to during elections', a leader of the Manyu community in Limbe told the newspaper. 'It seems whenever something goes wrong within the native population, the people are worked into believing that it is caused by Manyu people', the man added. Others have complained about bad and untarred roads, and blame local and national politicians for taking them for granted. Like the people of Donga-Mantung Division in the North West Province who have asked for the creation of a Far North West Province with a headquarters in Nkambe, some in Manyu Division have asked for their own province as a way of ending marginalisation and attracting administrative attention and resources. ${ }^{66}$ With the politics of autochthony, people have come to believe that it is only by having one's own administrative unit (subdivision, division or province), that one stands a good chance of benefiting from the national cake which different groups wish to appropriate to the detriment of others. The sheer increase in the number of requests for such administrative units tells the whole story. Each request is made in exchange for promises of support for the CPDM at elections. In the South West, the Bayang of Manyu are not alone in feeling that the Bakweri are receiving more than their fair share of representation in government and high office. The Bakossi elite of Kupe Muanenguba Division have also pondered why the Bakweri whose constituency is dominated by the opposition and whose numerical strength 'is negligible should occupy several key positions in government and the CPDM'. They claim not to have been adequately compensated for voting for the CPDM. ${ }^{6}$

65 Weekly Post, 8 April 1997, p. 1.

66 The Herald, 4-5 November 1996, pp. 1 and 3 and 2-4 May 1997, p. 3.

67 The Herald, 29-31 January 1997, p. 1. 


\section{Repression}

Most of the strategies employed by the government to deconstruct Anglophone identity tended to be accompanied by ruthless repression of the Anglophone population and Anglophone activities. ${ }^{68}$ The South West Provincial Governor Oben Peter Ashu became so unpopular following his decision in 1993 to brutalise the local population with the military in a bid to forcibly recover unpaid taxes and to stop smuggling that his name was corrupted to 'Obey Peter Shoot'. The North West Provincial Governor Bell Luc René a Francophone hailing from Douala, was nicknamed 'Bend Look Grenade' as a result of the security forces' excessive use of tear-gas grenades to disperse opposition rallies and demonstrations in the North West during the 1991 ghost town campaign and the 1992 state of emergency in Bamenda following 'Biya's theft of Fru Ndi's victory' in the presidential elections (Nyamnjoh 1996d: 110, footnote 129).

Major Anglophone opposition parties, like the North West-based SDF and the South West-based LDA, continued to be exposed to state intimidation and violence. As mentioned in Chapter 4, the launching of the SDF in May 1990 led to the killing by security forces of six demonstrators, the so-called Bamenda martyrs. The launching of the LDA in Buea on 19 September 1993 prompted the security forces to launch a tear-gas attack on the approximately 400 party sympathisers gathered at the premises of the party chairman, Njoh Litumbe. This act can probably be explained by the fact that the LDA executive was composed of some of the principal SCNC leaders, notably Sam Ekontang Elad, Simon Munzu, Henry Fossung and Njoh Litumbe. The government regularly prohibited the Anglophone opposition parties from holding rallies and the security forces often broke up those that did take place.

A well-publicised example occurred on Wednesday 3 November 1993 - the day set aside by the government to celebrate Liberty Week or 11 years of Biya's presidency - and involved a confrontation between a convoy led by John Fru Ndi of the SDF and the police in Yaoundé. CRTV mentioned the incident only on the Friday, after foreign broadcasters had made much of the event. The story went thus. The Mfoundi prefect had issued an order banning all political demonstrations and forbidding John Fru Ndi's scheduled news conference. The latter then organised a convoy from Tsinga towards his party secretariat behind the former Imperial Hotel (now the Prestige Hotel). The police attacked them with water canons. Fru Ndi was claimed to be injured and his car damaged. He escaped and took refuge in the residence of the Dutch

${ }^{68}$ For an extensive report on the government's violation of human rights in the Southern Cameroons, see Ayamba 2001. 
ambassador in Mvolye, and gave an ultimatum for the release of the thirty SDF militants arrested. The police were rumoured to have been intending to kill him. The notorious head of Cameroon's internal security, Jean Fochive ${ }^{69}$ gave a press conference claiming that all those arrested had been released but for a certain Shey Philip who had been found with ammunition and two walkietalkies. But even he was eventually released. He then proceeded to accuse Fru Ndi of seeking cheap publicity and of always deliberately disrespecting the law of the land. He offered to give Fru Ndi a police escort to Bamenda if the latter was afraid, as he claimed, that his life was in danger.

According to Augustine Tegomoh (interviewed by Nyamnjoh shortly after the incident) who participated in the incident and was quite close to the chairman, no stones were thrown by the crowd, contrary to claims by the official media. The chairman gave a scheduled press conference in Tsinga. On his arrival, he saw the place crowded with policemen who were molesting and arresting those who had come to attend. When they saw the chairman, the crowd started chanting 'papa ley, Yaya you' (Papa welcome! We are pleased to see you again). Having been told that he was not allowed to hold his press conference, the chairman decided to go to his party's (SDF) provincial head office situated behind the Imperial Hotel. The crowd that followed him continued to swell as he drove along. It was a real test of his popularity, Augustine claimed. Everyone who saw him followed him, shouting 'you are the man we want'. Around the prime minister's office the police, backed by lots of four- and five-star commissioners, blocked the way. The chairman told the crowd to be calm and no one threw any stones at the police. Diplomatic representatives, Vincent T'sas of Reuters and others who were there can attest to this. The police focused their water canon on the chairman's Pajero car. The chairman stayed calm but was wounded on his arm and hip by broken glass.

Minister of Communication and Government Spokesman Augustin Kontchou made it sound as if the Dutch ambassador was Fru Ndi's friend because Fru Ndi had taken refuge in the Dutch embassy but the latter had simply gone to pay him a visit. 'Monsieur Fru Ndi est allé rendre visite à son ami diplomate', and stayed there for as long as he wanted, and when he was satisfied, they shook hands and he departed. Kontchou apparently contradicted the CRTV announcement that Fru Ndi had left the Dutch embassy following the diplomatic intervention of the French ambassador. No such intervention actually occurred as there was no need for it. People are allowed to have friends among diplomats. Why the fuss?

69 For a concise description of his internal security career, see Takougang \& Krieger 1998: 93 and 227-28. 
The Anglophone movements were also frequent victims of government repression. In 1993, the government did not allow the convenors to hold AAC I in public buildings in Buea such as at the University of Buea, which would have been the most appropriate location for the occasion. The government refusal did not have the desired effect of cancelling the AAC I, since the Catholic authorities eventually gave their agreement to the use of a hall in the Mount Mary Clinic in Buea. ${ }^{70}$ In 1994, the government attempted to obstruct the organisation of AAC II in Bamenda by claiming that 'Anglophones had come together in Bamenda to declare secession' as an excuse for repression. ${ }^{71}$ On that occasion, Chairman Sam Ekontang Elad had to be smuggled out of the Mondial Hotel disguised as a steward, the hotel having been surrounded by government troops. ${ }^{72}$ Demonstrations and strikes organised by the various Anglophone associations and pressure groups were quelled by government troops. For example, 'Independence Day' celebrations on 1 October 1993 were violently disrupted by the security forces, the government again suspecting that on that day secession and independence would be declared. Leaders of Anglophone movements were harassed by the security forces, threatened with arrest, and subjected to travel restrictions, forcing some to go into exile. ${ }^{73}$ Repression increased with mounting threats of the proclamation of an independent Southern Cameroons state after 1995. SCNC rallies and demonstrations were then officially banned in Anglophone provinces. ${ }^{74}$ Repression became even more severe in the aftermath of the SCYL attack on military and civil establishments in the North West Province in March 1997 and the actual proclamation of Southern Cameroons' independence by Justice Ebong on 30 December 1999 (see Chapter 4). Press censorship by the administrative authorities, the seizure of newspapers, intimidation and imprisonment of Anglophone journalists have all continued unabated.

The government also intensified its crackdown on any event organised by scholars and activists to foster a feeling of community or to celebrate Anglo-

70 See 'The Untold Story of the All Anglophone Conference', in Cameroon Life, Vol. 2, No. 8, May 1993, pp. 11-12.

71 See Cameroon Post, 20-27 April 1994, pp. 2-3; The Herald, 28 April-1 May 1994, pp. 1-2 and Cameroon Post, 29 June-6 July 1994, pp. 6-7.

72 See Cameroon Post, 6-12 May 1994 and 12-19 May 1994.

73 See Cameroon Post, 10-17 July 1995, pp. 1 and 3 for an example in Governor Oben Peter Ashu's declaration that ' $\mathrm{SCNC}$ is ... an illegal pressure group which wants to turn Buea into a battle ground' and that 'we must chase the leaders of that group out of this province'. See also Cameroon Post, 25 June-1 July 1996, pp. 1, 7 and 11, for the article 'Arrest of SCNC Leaders Imminent' and for SCNC Chairman Henry Fossung's interview on this and other issues.

74 See Cameroon Post, 24-31 July 1995, pp. 1 and 3 and The Herald, 31 July-2 August, 1995, pp. 1-2. 
phone achievements and identity. A scheduled launching of Nyamnjoh's book The Cameroon GCE Crisis: A Test of Anglophone Solidarity (1996a) was banned at the last minute, and the author, Asong Wara (organiser) and Christian Cardinal Tumi (chief launcher) threatened with 15 days renewable detention should they proceed despite the ban. Subsequent bans were brought to bear on the launching of a booklet by lawyer and activist Charles Taku entitled For Dame Lynda Chalker and Other Anglophone Cameroonian Notes (1996), and of Ambassador Nsahlai's book Up to the Mountain Top: Beyond Party Politics (1996). At the University of Buea, any academic or student even remotely sympathetic with or politically involved in the Anglophone cause has been victimised in one way or another by a vice-chancellor and collaborators who have been bought into the regime's programme of trivialisation and demonisation of Anglophoneness in Cameroon. The University of Buea, although created as an Anglo-Saxon university to satisfy the Anglophones as a whole, has increasingly been identified first as a CPDM South West university, and then as a CPDM Bakweri university. The vice-chancellor (who is a member of the political bureau of the CDPM) and the registrar of the university are active local CPDM militants. They are both Bakweri and come from the same village in Buea. The Fako Elite Development Organisation (FEDO) frequently influences decision-making at the university, and despite complaints by other staff that neither this nor the appointment of top management from the same village and ethnic group is good for the institution, the state has allowed the situation to prevail. Dr Dorothy Njeuma, the vice-chancellor, Registrar Herbert Endeley and other Bakweri members of staff as Bakweri 'sons and daughters' treat the university as 'our university'.

\section{Conclusion}

In this chapter it has been shown that the Biya government has made a determined effort to deconstruct Anglophone identity and to contain the threat of Anglophone organisations. It has employed several strategies that have dealt a heavy blow to the initially powerful Anglophone opposition parties and movements. These strategies have included the trivialisation and demonisation of the Anglophone problem, the establishment of control over the state media, the punishing of any journalist and/or public intellectual who has dared to propagate Anglophone identity and solidarity, and encouragement of the ethnic-regional print media, as well as outright repression.

The most important strategy, however, has been divide and rule, capitalising on the existing contradictions between the South West and North West. Seeing themselves as having suffered greater disadvantage than North Westerners in 
the distribution of state power, the South West elite were inclined to see more political capital in the promotion of regional identity and organisation than in working to consolidate an Anglophone identity and organisation. The government, therefore, found it increasingly lucrative and politically expedient to tempt the South West elite away from Anglophone solidarity with strategic appointments and the idea that their real enemy was the North West elite and not the Francophone-dominated state.

Government divide-and-rule tactics culminated in the 1996 constitution. This constitution stretched the conventional notion of autochthonous minorities to such ambiguous proportions that historical minorities like the Anglophones had themselves denied the status of minority, while ethnic-regional minority groups like the South West ethnic groups and the SAWA (Douala), which appeared to distance themselves from the opposition, have met with government support. The constitution fuelled existing tensions between South Westerners and North Westerners in the Anglophone territory. The pro-CPDM South West elite increasingly tended to accuse the large-scale northwestern settler population of domination and exploitation, land grabbing and ingratitude to the welcoming indigenes. They have not hesitated to use the settler presence to explain all political disturbances in the South West Province, even going as far as insinuating that the poor performance by the ruling CPDM and secessionist tendencies among Anglophones could be attributed wholly to the settler opposition and dissidents. The litmus test for 'South-Westness', it would appear, has become membership and militancy in the CPDM.

The constitution has equally stimulated an alliance between the ethnicallyrelated Anglophone and Francophone coastal elite (Grand SAWA Movement) on the basis of common feelings of domination and exploitation by Anglophone and Francophone Grassfielders (Grand West). The Grand SAWA Movement is opposed to wider Anglophone ambitions, including separation from Francophone Cameroon or the creation of a two-state federation. Like most Francophones, the pro-CPDM South West elite continues to strive for a ten-state option, which they regard as a safe guarantee against North West domination. The Grand SAWA Movement demonstrates strong allegiance to the regime in power for the latter's protection and strategic appointments in government.

It is with this divide in the Anglophone identity that the Biya government has made considerable progress in undermining support both for the North West-based SDF and the Anglophone movements' pursuit of autonomy in the form of either a two-state federation or an independent Southern Cameroons state. We have, however, provided evidence that the regime has failed to fully deconstruct the Anglophone identity, even among elites who support the CPDM and the government. A growing number of CPDM leaders appear to 
identify with Fuh Stanley, the president of the Bafut section of the CPDM in the North West when he openly confessed in February 2000: 'I am CPDM in blood and bones, but we must admit that Anglophones have a problem' ${ }^{75}$ The proclamation of Southern Cameroons' independence by Justice Ebong on 30 December 1999 appears to have given added impetus to the Anglophone struggle.

75 The Post, 14 February 2000, p. 3. 


\section{The Anglophone struggle for the preservation of its educational and economic legacy}

Among the many confrontations between the Francophone-dominated state and Anglophone organisations, two deserve particular attention. The first is the Anglophone demand for an autonomous General Certificate of Education (GCE) Board in the 1990-1993 period and the second concerns Anglophone protests against the government-announced privatisation of the Cameroon Development Corporation (CDC) in 1994. During these confrontations Anglophones displayed a sense of solidarity never seen before. In this chapter we show that their exceptional unity may be attributed to the fact that they were determined to forestall the Francophone-dominated state's total dismantlement of their educational and economic legacy. Two of the remnants of Anglophone heritage and identity, the GCE and the CDC, were in danger of being taken over by Francophones.

Confronted with this unexpected Anglophone solidarity, the regime was forced to make concessions but the Anglophone victory was short-lived. When the Anglophone movements started losing momentum and internal divisions among them reappeared, the regime began to regain its lost terrain and to withdraw previously offered concessions. 
The Anglophone struggle for the preservation of its educational legacy

\section{The GCE crisis}

Following reunification, the Francophone-dominated government strove to harmonise the two different colonial educational systems. Initially, the Anglophones tended to support this harmonisation drive on the assumption that it would eventually result in the adoption of the best elements in both colonial legacies. They became increasingly worried when harmonisation turned out to be an ill-concealed Francophone attempt at assimilation and even dismantlement of their educational system, which they rightly perceived as a direct threat to the preservation of their Anglophone identity.

Harmonisation attempts, in fact, posed many problems to Anglophone students and began to lower educational standards in Anglophone Cameroon. A few examples suffice here. Technical colleges in the region were systematically subjected to harmonisation and were obliged to introduce the Francophone curriculum and examination system. They became almost exclusively staffed by Francophones, with most teaching either in French, Pidgin English or what Anglophones tend to call 'Franglais'. No wonder that the students had little chance of passing their examinations. Students who turned to external examinations, like the City and Guilds and the Royal Society of Arts (RSA) were likely to be frustrated by the ministry of national education. Moreover, in sharp contrast to Francophone Cameroon, Anglophone Cameroon had once been proud of its excellent teacher-training traditions characterised by high standards of professional and ethical formation and Spartan discipline. By the end of the 1960s there were twelve teacher-training colleges in the region almost exclusively owned and run by the established churches. All were boarding institutions that offered a five-year course for primary school teachers. By the middle of the 1970s practically all the colleges had closed as a result of a subtle policy of asphyxiation on the part of the Francophone-dominated state. Their closure had a negative effect on the quality of primary education.

Against this background, it is understandable that Anglophones began to openly resist the Francophone onslaught on Anglophone education. In 1983, Anglophone students at the University of Yaoundé strongly opposed government attempts to harmonise the Anglophone GCE Ordinary and Advanced Levels with the Francophone Baccalauréat (BAC). In a ministerial circular of 27 September 1983, René Ze Nguele, the Francophone minister of national education proposed a new group certificate GCE, ' stressing that 'it would make the GCE look a little more like the BAC' and help Anglophones to gain

This ministerial circular is reproduced in Nyamnjoh 1996a: 42-47. 
admission to higher institutions of learning in Cameroon. Anglophone university students became infuriated when they gained access to the circular following its publication in the national weekly, the Cameroon Tribune, on 16 November 1983. They spontaneously agreed that they had to take action for 'the Francophones had gone too far'.

It is not surprising that these students took the initiative to defend Anglophone interests. They themselves were facing hardship in the highest institute of learning. Though officially a bilingual institution, the University of Yaoundé was clearly a Francophone institution. This was once again illustrated by the dismissal of Dr Bisong, an Anglophone lecturer in the department of economics, simply because he was not yielding to Francophone pressures in the university to teach in French and 'Frenchify' his course content (see Chapter 3). The students strongly condemned the assimilationist tendencies in the ministerial circular, arguing that the problems faced by Anglophone students in the higher institutes of learning were not due to their inadequate educational background but rather to these institutes' Francophone orientation and curriculum. They then vowed to save the GCE from the fangs of Francophone assimilation and reiterated the need for true bilingualism in the university. They drew up a petition demanding the repeal of the proposed reforms. On 22 March, they marched to the ministry of national education where they were met by security forces who prevented them from presenting their petition to the minister. They then decided to boycott classes and organise daily demonstrations. For eleven days they braved all odds, being constantly surrounded and attacked by heavily armed troops and being described in the government-controlled media as enemies of national integration. ${ }^{2}$

Eventually, on 2 December, a meeting was arranged between student representatives and a government delegation, including a substantial number of prominent Anglophone politicians such as Solomon Tandeng Muna, the then speaker of the national assembly, John Ngu Foncha, Emmanuel Agbor Tabi and Professor Bernard Fonlon. The government delegation informed the students that President Biya was requesting they resume classes while their grievances and other matters affecting education received appropriate attention. Meanwhile, the proposed reforms were suspended indefinitely. After some hesitation, the students decided to call off their strike. ${ }^{3}$

In an attempt at appeasement, President Biya set up a commission in 1984 to study problems related to the GCE. This commission, chaired by Professor Joseph Mboui, the Francophone secretary-general at the ministry of national education, spent huge sums of money touring Cameroon, West Africa, Britain

2 See The Messenger, 25 November 1993, p. 11.

3 For a full account of the students' protest actions, see Nyamnjoh 1996a: 19-70. 
and Canada, but never submitted a report. In 1989, another Francophone minister of national education, Professor Georges Ngango, attempted to introduce a new GCE reform scheme that would impose on Anglophones the Francophone structure of four years for the first cycle and three years for the second cycle. Fierce opposition and widespread demonstrations by Anglophone students and parents forced the Biya regime to sack the minister and halt the scheme. Loss of confidence in the Biya regime increased with this new attempt to destroy the GCE.

By 1990, there was ample evidence that the ministry of national education was managing the GCE examinations poorly, leading to severe abuse of the system and numerous irregularities in the conduct of these examinations. Francophone officials attempted to establish control over the GCE, notwithstanding the fact that most either lacked competence or neglected their responsibilities. Financial problems compounded the situation. The ministry proved incapable of paying their local examiners and the University of London regularly for their services and in 1990, the University of London decided to suspend its cooperation with the ministry as a result of debts amounting to FCFA 350 million. The consequences were disastrous. Typists who did not understand a word of English were recruited to type examination questions. The proofreading, printing and packaging of examination questions were badly handled. The GCE examinations were rapidly losing their traditional high standards and reputation as gross errors were made at all levels. It was only a matter of time before its credibility started to sink too. ${ }^{4}$

Given these circumstances, Anglophone secondary and high-school teachers organised a meeting at Government School Atuakum in the North West Province on 25 April 1991 to discuss the problems related to the GCE examinations. Discussions focused on the non-payment of examiners for their services and the continuing existence of Yaoundé as one of the marking centres. ${ }^{5}$ The teachers resolved that all dues owed to the GCE examiners for the period 19841990, including marking fees and out-of-station allowances, be paid to them by the ministry of national education before the commencement of the correction of the 1991 GCE scripts. 'Money for left hand, red pen for right hand', they stated in Pidgin English. They agreed that there should be only two marking centres, Bamenda and Buea. Most of the examiners lived in these two centres and this would thus require fewer payments of living allowances. At the end of the meeting they decided to organise themselves into an association, the Teachers' Association of Cameroon (TAC), for the defence of their interests.

4 See Nyamnjoh 1996a: 11-12.

5 See Cameroon Now, 5-12 June 1991, p. 3. 
Becoming increasingly concerned with the falling standards of GCE examinations, the TAC soon broadened its objectives to include the creation of an autonomous GCE Board as a matter of utmost urgency. In fact, it made the marking of the 1992 GCE examination scripts dependent on the government installation of such a board.

The Anglophone struggle for an autonomous GCE board

In its struggle for the establishment of an autonomous GCE board, the TAC received much-needed support from parents, students, churches, associations, political parties and the private press in Anglophone Cameroon, all being convinced that the TAC's struggle was of great importance to the preservation of Anglophone education and identity. In the course of the struggle, the existing Anglophone Parent Teacher Associations (PTAs) ${ }^{6}$ formed an umbrella organisation, the so-called Confederation of Anglophone Parent Teacher Associations of Cameroon (CAPTAC). Following their foundation in 1992/93, the Cameroon Anglophone Movement (CAM) and the All Anglophone Conference (AAC) joined the fight. Most political parties also became involved though to differing degrees. The majority of the pro-CPDM elite and chiefs, however, either kept silent or condemned the struggle, often seeing it as another ploy by the Anglophone parties, in particular the SDF, to attack the government. Interestingly, while most Francophones did not understand what the struggle was all about, some of the Francophone opposition papers backed the struggle, as did popular Francophone intellectuals like Mongo Beti.?

Confronted with the persistent refusal of the TAC to mark the June 1992 GCE examinations until the government had approved the installation of an autonomous GCE board, the newly appointed Anglophone Prime Minister Simon Achidi Achu finally decided on 11 September 1992 to appoint a committee charged with making recommendations on the structure, organisation and operation of such a board. Apart from the intensified pressure from the TAC and parents, other considerations may have influenced the prime minister's decision. First, the 1992 presidential elections were rapidly approaching and the GCE question could further undermine Anglophone support for the incumbent president. Secondly, the prime minister tried to win time and lure the TAC into marking the GCE examination scripts. The examiners were promised that the GCE Board would be in operation before the June 1993 examinations. As a result, the striking examiners marked the $1992 \mathrm{GCE}$ examination scripts.

6 For the PTAs in Cameroon, see Boyle 1996 and 1999.

7 See Mongo Beti 1993: 77-82. 
After two months of intensive work, on 20 November 1992, the committee, which was mainly composed of Anglophone experts and headed by Professor Luc Beiban Sondengam, submitted its report to the minister of national education. Its report contained both a project for the decree creating the board ${ }^{8}$ and a project for the text of application of the decree. It was widely commended as an excellent piece of work and even the minister of national education appeared to be impressed.

Significantly, it was only after a series of follow-up sessions and extreme pressure by TAC and parents that the minister forwarded the report with favourable comments to the prime minister on 7 January 1993. The latter said that he would immediately pass it on to the presidency for the final decision to be made, assuring the National Executive of the TAC that the decree creating the board would be signed by the end of February 1993.

By March 1993, the TAC was sending out warning signals. The June 1993 examinations were not going to be marked before the creation of the board. The government nevertheless ignored these signals. The TAC then took the initiative of installing a board in Buea on 16 April 1993. According to its executive, this was to ensure that the board would have adequate time to handle the $1994 \mathrm{GCE}$ examinations effectively. At that point, TAC members pledged to continue fighting till their objectives had been realised. The ministry of national education quickly declared the board illegal, and everything was done to discourage its effective operation.

When no examiners showed up at the marking centres in mid-June, the government was obliged to devise a new scheme to mark the 1993 GCE examination scripts. The Francophone secretary-general at the presidency, Professor Joseph Owona, returned the draft decree to the minister of national education, Dr Robert Mbella Mbappe, with clear instructions on how to proceed. Interestingly, Anglophone Prime Minister Simon Achidi Achu was ignored in this endeavour. A carefully selected team of directors in the ministry of national education, nearly all Francophones, was called upon to study the draft decree on the board and make recommendations to the presidency.

As a result of the work of this team, President Biya signed a vague decree creating the GCE Board on 1 July 1993. The decree deliberately left out a text of application as recommended by the report of the Sondengam Committee. Moreover, it tended to restrict the board's responsibility to the GCE only, thus ignoring the frequently expressed TAC demand for a board that would cater for the entire Anglophone education system and examinations. After some hesita-

8 The Sondengam Report proposed a Cameroon Examinations Board (CEB) that would take care of all Anglophone examinations. This was in agreement with the TAC's initial proposal. 
tion, the TAC nonetheless accepted the decree in principle, arguing that a future text of application of the decree could reflect its aspirations. However government hopes that the signing of the decree would encourage the TAC to start marking the 1993 GCE examinations were dashed. The TAC made the government understand in no uncertain terms that marking would be conditional on the government's publication of the text of application and the actual installation of the board. It did not want to be deceived once again by the government. Minister of National Education Mbella Mbappe then employed all the weapons at his disposal to get the GCE examinations marked. His greatest miscalculation was to think that threats, insults and intimidation would create panic and disunity among the teachers. Armed with a long history of militancy (Verdzekov 1969), capable leadership and strong support from the vast majority of the Anglophone community, the teachers stood firm.

On 19 August 1993, Mbella Mbappe called a meeting at the ministry of national education attended by members of the Final Award Committee, moderators and chief examiners. While many had expected that the minister would use this occasion to arrive at a final settlement with the Anglophone teachers and parents, he instead strongly attacked the TAC and CAPTAC. To the consternation of the Anglophone community, he even displayed a large measure of insensitivity with regard to the educational system in the country, boasting that he himself had no children studying in Cameroon. He summoned all examiners to report to the marking centres by 24 August 1993. They were given two weeks to finish marking and he threatened those who dared to disobey his orders (Nyamnjoh 1996a: 14).

Realising very soon that intimidation had not had the desired effect, the minister altered his strategy, now being prepared to make some concessions. $\mathrm{He}$ created an ad hoc committee mainly composed of former members of the Sondengam Commission to rewrite and re-table the text of application for the GCE Board. Yet, he assured the committee members that they could take their time and that there was no hurry! Being aware of the explosive mood in the Anglophone community, the committee ignored the minister's instructions. It worked day and night to complete the assignment and submitted the text on 14 September 1993. In addition, the minister signed an order on 12 September 1993 that closed the Yaoundé marking centre, leaving Bamenda and Buea as the only marking centres.

Furious that the teachers were still refusing to start marking after these concessions, the minister ordered the armed forces to remove the GCE examination scripts from Bamenda and Buea a few days later. During the night of 14 September 1993, soldiers secretly broke into the Bamenda and Buea marking centres and took the scripts to Yaoundé. It took some days before the minister actually admitted that the scripts were in Yaoundé. 
With the assistance of Anglophone CPDM leaders like Dr Peter Agbor Tabi, the rector of the University of Yaoundé, the minister then started recruiting new markers, particularly among Francophone students, who were often not properly qualified for the job. Recruiters and markers appear to have been well rewarded for their work. A budget of FCFA 600 million was reserved for the purpose. Agbor Tabi's wife was reported to have received FCFA 22 million for her delivery of identification badges for the markers. At the same time, Mbella Mbappe and other government officials continued to tell Anglophone teachers to start marking in Yaoundé or face the consequences.

These developments shocked Anglophones. The Anglophone Roman Catholic bishops and the Presbyterian Church leaders appealed to the government, and particularly to the Anglophone Prime Minister Simon Achidi Achu to intervene in the matter, to return the GCE examination scripts to Bamenda and Buea, and to sign the text of application of the decree creating the GCE Board (Nyamnjoh 1996a: 117-45; Nyansako-ni-Nku 1993: 49-54). On the request of the prime minister, the Roman Catholic bishops organised a tripartite meeting on 3 October 1993 between the prime minister, the TAC and themselves to finally resolve the GCE stalemate. While the participants were convinced at the end of this meeting that they had come close to a solution, Mbella Mbappe, without awaiting the results of the meeting, issued an order the following day requesting that the newly recruited markers proceed with their work.

On 7 October 1993, CAPTAC warned Mbella Mbappe that it would never accept the results of GCE examinations marked by unqualified staff. It threatened to withdraw its children from school if the government refused to negotiate with the TAC for the effective marking of the GCE examinations. The minister provoked the CAPTAC delegation by replying that 'he and the government were always right', that 'he intended to restore the authority of the state', and that 'he would make sure that the GCE would be marked by all means'. In addition, he remarked that 'if they disapproved of the present markers, they should bring pressure to bear upon their own examiners to start marking'.

The situation deteriorated quickly. On 12 October 1993, Anglophone parents turned out in large number and demonstrated in front of the ministry of national education in Yaoundé and the provincial delegation of education in Bamenda. In Yaoundé, they were brutally dispersed by security forces but in Bamenda, the crowds held the Provincial Delegate for National Education Chief Martin Forbuzie hostage for six hours..$^{10}$

The Herald, 13-20 October 1993, p. 5.

10 Cameroon Post, 20-27 October 1993, especially the report on the Yaoundé demonstration by Julius M. Wamey entitled 'The GCE Saga: Vidi Aquam (I saw water)'. 
This time the regime reacted promptly to these demonstrations. On the same day, a text of application creating the GCE Board was read on the national radio in French. Anglophones, however, rejected this text since it excluded technical examinations from the board's control. Prime Minister Simon Achidi Achu sent an envoy to Bamenda the next day to negotiate a more acceptable version with the TAC. This text was published on 15 October 1993.

The final text still remained a far cry from what the TAC and the Anglophone community had been clamouring for. It was a clear reflection of the compromises made between the government and Anglophone organisations. While Anglophones strove for an autonomous board, the text still provided the government with a measure of control. The government had a considerable say in strategic appointments. The text did not conceal government intentions of keeping the board under close supervision. Article 4 reads: 'The Minister of National Education shall be responsible for the supervision of the Board'. And Article 45 states: 'The financial management shall be handled according to regulatory provisions applicable to public corporations of administrative nature'."1

Having lost faith in the regime, teachers still refused to start marking the GCE scripts until the board members were appointed and installed. Their lack of faith appeared to be justified when Minister Mbella Mbappe declared during a press conference on 19 October 1993 that the appointment and installation of the GCE Board was not an urgent matter and that schools were to re-open on 21 October 1993 even if the marking of the GCE scripts had not yet been completed. ${ }^{12}$

On 25 October 1993 Anglophones savoured a rare moment of triumph when the board was finally installed in Buea and Mr Sylvester Dioh, an experienced educational administrator, was appointed as its first chairman. Later on, $\mathrm{Mr}$ Andrew Azong Wara, the TAC president, was nominated as its first registrar. The Anglophone victory was short-lived, however, Since the GCE Board was more or less forced upon him, it was to be expected that Minister Mbella Mbappe would do all in his powers and means to destroy it. He used several strategies to this end.

Immediately after the installation of the board, he attempted to undermine its authority. When Anglophone teachers took over the marking of the GCE scripts in Yaoundé, he claimed that almost the entire budget reserved for the marking exercise had already been allocated to the former examiners appointed by the ministry of national education. Determined not to endanger the board's continued existence, the teachers then decided to mark without compensation.

11 For the text, see Nyamnjoh 1996a: 179-92.

12 Cameroon Post, 27 October-3 November 1993, p. 8. 
Although the marking period resulted in much personal hardship, including problems with paying for food and transport to and from the marking centres, they still persevered. Parents assisted in various ways and contributed a paltry sum of FCFA 250,000, and the Anglophone Prime Minister Simon Achidi Achu donated FCFA 2 million as a personal contribution. It was only after the completion of the marking and publication of the results that parents sent their children back to school.

Following this failure, Mbella Mbappe began to withhold the necessary subventions to the board. According to the board's authorities, the minister gave a financial subvention of FCFA 166 million during the first year of its operations, FCFA 44 million during the second year, and nothing in the third year. This compared most unfavourably with the ministry of national education's yearly subventions amounting to FCFA 3.2-3.6 billion prior to the creation of the board. ${ }^{13}$ As a result, the board was obliged to rely heavily on the benevolence of the teachers and parents and to take out loans in order to organise the examinations. ${ }^{14}$ Due to continuous financial problems, it was also forced to lay off a number of staff.

Another strategy to cripple the board was the minister's attempt to shift the debt of over FCFA 500 million owed by the ministry's department of examinations to the London University Examinations Board to the GCE Board. Although this attempt eventually failed, it led to strained relations between the GCE Board and the London University Board - a situation that did not augur well for the young institution. ${ }^{15}$

On 5 September 1995, Mbella Mbappe again declared that the government was not going to recognise the technical examinations organised by the GCE Board. It was not until the personal intervention of the Anglophone Prime Minister Simon Achidi Achu that the minister was prepared to settle the matter with the angry TAC leadership. ${ }^{16}$

The most important strategy was the minister's attempt to replace TAC activists on the GCE Board with pro-CPDM leaders who tended to be less committed to the Anglophone cause. He directed his attacks foremost at Azong Wara, who doubled as registrar of the GCE Board and TAC president. In 1996, the position of the North Westerner Azong Wara, who continued to champion an autonomous GCE board, was seriously undermined by two factors.

13 See National Express, 12-18 June 1996, p. 2 and The Herald, 21-23 March 1997, p. 5.

14 The Post, 8 May 2000, pp. 1 and 5.

15 Cameroon Post, 24-31 July 1995, pp. 1 and 5.

16 The Herald, 9-11 October 1995, pp. 1-2; Today, 2 October 1995, p. 3 and Cameroon Post, 24-31 July 1995, pp. 1 and 5. 
First, there was the unfortunate GCE examinations leakage in that year. ${ }^{17}$ Mbella Mbappe then quickly set up a dubious commission of enquiry - something he had never done with the Francophone BAC and Brevet leakages in 1995. He appointed as its chairman a South Westerner, Dr Herbert Endeley, son of Emmanuel Endeley and registrar of the University of Buea, a staunch CPDM member who was generally known to be more interested in advancing southwestern than Anglophone interest (see Chapter 5). Significantly, when interviewed during a CRTV 'Cameroon Calling' programme on 18 August 1996, Endeley suggested that part of the organisation and running of the GCE examinations be handed back to the government. ${ }^{18}$

Second, there were the two strikes by teachers in 1996 aimed at an improvement in their conditions of service. TAC members soon lost confidence in their leader Azong Wara who did not support the first strike and - after initial support - even called off the second strike. TAC members then accused him of being a traitor and demanded his resignation as leader of the association. ${ }^{19}$ There is no doubt that the government took advantage of this situation to bring about Azong Wara's downfall as registrar of the GCE Board.

After the presentation of his report of enquiry into the 1996 GCE examinations leakage, Herbert Endeley was appointed chairman of the GCE Board. On 12 March 1997, he convened an extraordinary session of the GCE Board, ostensibly on the instructions of Mbella Mbappe. During this meeting, Azong Wara was replaced by Dr Omer Yembe, a North Westerner with a more conciliatory nature..$^{20}$ The latter used to be a member of the 'Gang of Five' that tried to forestall the holding of AAC II in Bamenda in 1994 (see Chapter 4). A number of TAC hardliners and Anglophones committed to an autonomous GCE board, notably Mr John Fodji, Rev. Yufanyi, Rev. Dr Ndingwan, and Dr Nsai, were equally removed as board members. ${ }^{21}$

The government was sure that those now in power at the GCE Board would implement the provisions of a secret decree (no. 97/046) signed by President Biya on 5 March 1997 that 'placed the GCE Board under the authority of the Minister in charge of National Education'. This new decree gave the minister of national education overall power to control the board. It thus contrasts sharply

17 Many Anglophones believe that this leakage was engineered by the government itself.

18 Cameroon Post, 27 August-2 September 1996, p. 2.

19 The Herald, 3-5 January 1997, pp. 1-2.

20 Azong Wara was not immediately re-instated in his position as teacher or redeployed. Feeling frustrated and abandoned, he gradually turned his energies and intellect to SCNC activism.

${ }_{21}$ Cameroon Post, 11-17 March 1997, p. 1. 
with the decree of 15 October 1993 that granted the minister only supervisory powers

\section{The Anglophone struggle for the preservation of its economic legacy}

\section{CDC privatisation}

Privatisation has been put forward by international donors as one of the magic formulas that could cure the ailing Cameroonian economy. For many years until the mid-1980s, the economy of Cameroon had been viewed as one of the rare success stories in Africa. This was not without foundation: Cameroon's economic performance was impressive, registering a phenomenal growth rate of 6-7 per cent during the 1970-1986 period (Jua 1991). However, as Hugon (1968) was the first to point out, this optimistic view tended to ignore certain weaknesses in the domestic economy which constantly threatened the 'growth miracle' - in particular the economy's almost total dependence on the export of agricultural raw materials and, more recently, of oil. This particular weakness became increasingly manifest from the mid-1980s onwards when a sharp fall in the prices of these commodities on the world market, together with a 40-percent depreciation of the US dollar relative to the CFA franc, plunged the domestic economy into severe crisis (Mama 1996). This situation was worsened by large-scale mismanagement, embezzlement and capital flight estimated at FCFA 150 billion a year - a quarter of the annual national budget. Apparently the much-trumpeted slogans of 'rigour and moralisation', which Paul Biya had coined on succeeding Ahmadou Ahidjo as president in 1982, had been nothing more than hollow phrases. After some procrastination, the government was forced to adopt a structural adjustment programme (SAP) in 1988/89 containing such conventional prescriptions as cuts in public expenditure, increased state revenues, privatisation and rigorous liberalisation (Van de Walle 1993; Konings 1996a).

At the start of the economic crisis, there were some 175 public enterprises in the country employing around 80,000 people. A considerable number of agroindustrial parastatals had been created or expanded after independence with the aid of international donors (Konings 1993a). These public enterprises served both economic and political ends. Besides being political avenues to economic modernisation and growth, they allowed the government to engage in prebendal politics and to cement a hegemonic alliance, incorporating the country's emerging elite into the state apparatus (Bayart 1979). A patrimonial logic existed in many post-colonial African states (Chabal \& Daloz 1999) but it was particularly strong in Cameroon, a country with stark ethnic and regional 
cleavages (Nyamnjoh 1999; Gabriel 1999). It is beyond any doubt that this logic contributed to the poor performance of most public and para-public enterprises (Tedga 1990; Van de Walle 1994). Prior to the economic crisis, the Cameroonian government was subsidising parastatal sector losses to the tune of some FCFA 150 billion a year. Though much of the oil revenue was initially kept in secret bank accounts abroad, its primary function soon became the covering of parastatal deficits.

From the very start of the economic crisis, the World Bank made parastatal reform a cornerstone of its lending conditions. Given the growing budgetary constraints, the Biya government officially agreed to cooperate. In May 1987 it appointed a national commission to recommend reform measures for the parastatal sector. One year later the commission reported back to the president, having determined which institutions should be liquidated, sold to the private sector or rehabilitated. However, few public enterprises were effectively privatised, only six between 1988 and 1994 (Mama 1996). Van de Walle (1994: 162) offered the following reasons for the slow pace of privatisation:

Although the government is proceeding with care on the politically sensitive issue of lay-offs, this does not appear to be the major constraint on rapid implementation of the reform agenda. Rather, intra-elite competition and haggling over the rents freed up by privatisation, along with the lack of technical expertise within the state, served to slow down the process of institutional reform.

Dissatisfied with the government's performance, the World Bank threatened in early 1994 to suspend credit of US\$ 75 million to Cameroon if the government did not accelerate the process of privatisation. Subsequently, on 14 July 1994, the government announced the privatisation of fifteen large public enterprises. Five agro-industrial parastatals, including the CDC, were among them. For various reasons, the announced privatisation of the CDC led to considerable commotion in the country, particularly in Anglophone regions.

The CDC is one of the oldest agro-industrial enterprises in the country, with its history being closely linked to the political and economic history of Anglophone Cameroon. It was founded in 1946 but its roots can be traced back to the German colonial period (1884-1914) (Ardener et al. 1960; Epale 1985; Konings 1993a). During that period many large-scale private plantations were created on the fertile volcanic soils around Mount Cameroon in the present South West Province. The establishment of a plantation economy in the region led to the expulsion of the original occupants of the land, notably the Bakweri, into prescribed native reserves (Courade 1981/82; Molua 1985). With the British occupation in 1914/15, the property of German planters was confiscated and turned over to the custodian of enemy property. When, shortly afterwards, the 
British took over the administration of the area, the plantations were merged and a government department was formed to manage them. By 1922, however, the British Mandate Authority had already decided to get rid of them as the administrative costs of maintaining them were said to be prohibitive. It then seriously considered returning the plantation lands to the original owners but in the end it dropped the idea. Instead, it concluded that it would be in the best interests of the territory and its inhabitants to put the plantations back into the hands of foreign private enterprise. At an auction held in London in November 1924 almost all the estates were bought back by their former German owners.

At the start of the Second World War, German estates were again expropriated by the custodian of enemy property and after the war, a decision had to be reached once more on how to dispose of the properties. The educated Bakweri elite, organised in the so-called Bakweri Land Committee, immediately began agitating for the return of its ancestral lands. It sent several petitions, first to the British Crown and subsequently to the United Nations, as Britain had assumed responsibility for the administration of the territory under United Nations trusteeship after the war. However, after considerable deliberation, the British Trusteeship Authority again declined to surrender the ex-German plantation lands to their original owners. Instead, it announced in November 1946 that they would be leased to a newly established statutory corporation, the Cameroon Development Corporation (CDC).

The corporation came into being with the passage of two ordinances in December 1946. The first of these, the Ex-Enemy Lands (Cameroons) Ordinance no. 38 (1946), provided for the acquisition of the ex-German plantation lands that had been vested in the custodian of enemy property for the duration of the Second World War. Under the terms of this ordinance, the Governor of Nigeria, responsible for the administration of the Southern Cameroons, was to declare them 'native lands' and hold them in trust for the common benefit of all inhabitants of the territory. The second ordinance, the Cameroons Development Corporation Ordinance no. 39 (1946), provided for the setting up of the corporation. All the lands acquired by the governor under the first ordinance were to be leased to this corporation for a period of sixty years. Significantly, the corporation was charged with a double responsibility: it was to develop and manage the approximately 100,000 hectares of estate lands in the interests of the people of the Trust Territory and it was to provide for the spiritual, educational and social welfare of its employees. After fulfilling all its obligations, the corporation was to pay direct taxes to the government of Nigeria and all profits were to be used for the benefit of the people of the Trust Territory.

The CDC was, and still is, the largest agro-industrial enterprise in the country. It is the second largest employer of labour, surpassed only by the government. It formerly employed 25,000 workers. At present, it still engages 
about 12,500 permanent workers and a few thousand seasonal and casual workers..$^{22}$ Interestingly, while the South West Province has remained the largest supplier of land to the CDC, the North West Province has become by far the largest supplier of labour to the $\mathrm{CDC}$, being responsible for about three-quarters of the corporation's labour force (Konings 1993a: 68). The CDC is one of the few agro-industrial enterprises in the world that specialises in a variety of crops: its four major ones are rubber, palm oil, tea and bananas. It has for a long time been dependent on foreign management. In 1960, the Commonwealth Development Corporation (COMDEV) took over the management of the corporation until 1974 when a North Westerner, Mr J.N. Ngu, was installed as the first Cameroonian general manager. The CDC management has since become almost completely Cameroonianised. Following independence and reunification in 1961, the corporation expanded its area of cultivation from 20,000 to more than 40,000 hectares with the help of huge loans from several well-known financial institutions including the World Bank, the International Development Association (IDA), the European Development Fund (FED), COMDEV, and the (French) Central Fund for Economic Cooperation (CCCE). In 1977 the government ordered the CDC management to expand outside its original base, the South West Province, in an attempt to transform the corporation from a regional to a national corporation. As a result, the CDC now owns a few estates in the North West Province and in the neighbouring Francophone West and Littoral Provinces. Nevertheless, the people of Anglophone Cameroon in general, and the South West Province in particular, have continued to perceive the CDC as 'their' corporation.

The CDC, in fact, has been of great importance to development in the Anglophone territory. Students of plantation agriculture, such as Beckford (1972), have blamed the persistent poverty and underdevelopment of Third World economies on this mode of production. In the case of the CDC, however, this thesis finds little support. The corporation has been a major instrument of modernisation and is largely credited with whatever socio-economic development has occurred in Anglophone Cameroon. It has created employment for many men and women, constructed numerous roads, supplied water and electricity, built and staffed schools, awarded a substantial number of scholarships, provided medical care for a large proportion of the local population, stimulated the supply of goods and services to itself and its workers and it has played a key role in the commercialisation and modernisation of peasant production. It worked as an intermediary in marketing the Bakweri peasantry's banana production in the 1950s and in the establishment of regional smallholders' oil-palm and rubber schemes from the early 1960s onwards (Ardener

22 CDC, Staff and Labour Force Return, October 1995. 
1958; Konings 1993b). Of late, it has handed over a substantial part of its oilpalm plantations to local contractors. The CDC has, as a result of all this, often been seen as the economic lifeline of Anglophone Cameroon.

The government announcement of the privatisation of this important agroindustrial enterprise was all the more shocking to the Anglophone population since the CDC (i) had been one of the rare public enterprises in Cameroon to perform relatively well until the economic crisis; (ii) had been able to survive this crisis mainly because the management and the workers had agreed to adopt a series of drastic adjustment measures; and (iii) was on the way to economic recovery following the 50-per-cent devaluation of the CFA franc in early 1994.

From its inception, the CDC has generally yielded positive results, though these have fluctuated over the years. In the three years preceding the crisis (1983/84-1985/86), the corporation was still making substantial profits, totalling FCFA 3.2 billion. The crisis, however, had a dramatic impact on the corporation's financial situation: during the 1986/87-1990/91 period it suffered a loss of about FCFA 18 billion (Konings 1993a and 1995b). Evidently, the sharp fall in commodity prices on the world market together with the 40-percent depreciation of the US dollar relative to the CFA franc were the principal causes of the near bankruptcy of the corporation. Nevertheless, other factors also contributed to the emergence and continuation of the crisis. First, there was the political elite's inability or unwillingness to control the impact of cheap tea and palm oil, which impeded CDC sales on the domestic market. Second, there have been frequent reports of the managerial elite's involvement in massive embezzlement, reckless expenditure, waste, and power struggles frequently based on ethnic and regional considerations.

The South West-North West divide, in fact, has often paralysed the corporation's administration. ${ }^{23}$ Since independence and reunification, the chairman of the CDC Board of Directors has usually been a South Westerner. Prominent SWELA members like Chief Victor Mukete, Chief Sam Endeley and Messrs John Ebong Ngolle and Nerius Nomaso Mbile have all occupied this position. The daily management of the corporation, however, has been dominated by North Westerners. The appointment of the North Westerner, Mr J.N. Ngu, as CDC general manager in 1974 occurred on the 'advice' of the corporation's external financiers but was strongly resented by the southwestern managerial elite. First, there were also some suitable southwestern candidates for the post, particularly Mr I.N. Malafa who used to be senior to Mr Ngu in the corporation's hierarchy having served as the deputy general manager during the last years of the COMDEV management. Second, the southwestern managerial elite

23 For a similar phenomenon in Pamol Ltd, a former Unilever subsidiary and another large agro-industrial enterprise in the South West, see Konings 1998. 
feared that Ngu's appointment would reinforce northwestern domination of the CDC management. Ngu's fourteen years in office (1974-1988) were marked by strong anti-North West feelings, he himself being regularly accused by the southwestern managerial elite of favouring his own countrymen. Ngu's conflicts with two of the southwestern CDC chairmen, Chief Victor Mukete and Chief Sam Endeley, have become almost legendary.

When Biya started to appoint South Westerners to key positions in the South West to reduce North West domination and to achieve a regional balance (Nkwi \& Nyamnjoh 1997), his close friend Ngu was replaced in 1988 by Mr Peter Mafany Musonge, a Bakweri. Ngu was then appointed as minister of agriculture, a post that, incidentally, had meanwhile become supervisory minister of the CDC. In this capacity Ngu continued to interfere in the running of the CDC, denying his successor the freedom to discharge his duties. The southwestern managerial elite alleged that Ngu was using his brothers among the management staff to harass or even get rid of Musonge. Together with other sections of the southwestern elite, they put constant pressure upon Musonge to reduce North West influence in the corporation. Particularly after the foundation of the SDF, the pro-CPDM elite associations in the South West and especially in the Bakweri area urged Musonge to sack northwestern managers suspected of being SDF supporters. In a strongly worded petition, the so-called Bakweri Elite Youth Wing declared in July 1991:

This is a reminder of an earlier letter to you this year in which we required you to support our fight against SDF and their 'Graffi' domination that has caused the Bakweri people to be deprived of what belongs to them. Mola, you have to redundant the following 'Grasslanders' who are strong supporters of SDF. They are Ngeh F., Che W., Tatani, Ndenesho, and Fomuso. Do this now. We are behind you. You are also supported by Chief Justice S.M.L. Endeley and all Vikumas. ${ }^{24}$

Just a few months before the announcement of the privatisation of the CDC, the South West-North West divide created such a severe managerial crisis that it even attracted the attention of the North West Prime Minister Simon Achidi Achu who, in turn, dispatched an investigation team from Yaoundé to reconcile the warring factions. Eventually, two northwestern managers, namely $\mathrm{Mr} \mathrm{Che}$, the Group Palms deputy manager, and Mr Tanyi, the Bota Palms manager, were sacked. These two men had the courage to admit that they were party to a memo by 22 management staff members of northwestern origin. The memo accused the CDC general manager, Peter Mafany Musonge, of ethnic discrimination and of favouring the Bakweri and victimising North Westerners. When it was leaked to Musonge before it had been signed, all of its authors except Che

24 See The New Standard, 30 July 1991. 
and Tanyi cowardly disowned it and apologised. After two regional papers both well known for their anti-North West views, The Sketch and The Weekly Post, had informed the public of the memo, the Bakweri elite organised a 'march of shame' in support of Musonge, with the participants carrying spears, machetes, dane guns and sticks, singing war songs and displaying placards proclaiming 'Sack all those North West managers', 'CDC is our own', and so on. ${ }^{25}$

Without doubt, these internal conflicts within the CDC management impeded management's ability to combat the economic crisis. Managerial problems were aggravated by the fact that the government was no longer prepared to render financial assistance to the ailing parastatal during the crisis. To save the company from total collapse, the management and the trade unions on the CDC estates agreed to adopt a series of adjustment measures aimed at reducing costs and increasing productivity (Konings 1995a and b). On 23 August 1987, the union presidents and management agreed on a substantial increase in the productivity of estate workers. For example, the daily quota required of tea pickers was raised from 26 to $32 \mathrm{~kg}$ of green leaves. And as the corporation's financial position continued to deteriorate, management proposed further austerity measures to the union's presidents. Following negotiations, a new agreement was signed on 6 January 1990 that involved drastic cuts in the salaries and fringe benefits of all workers and managerial staff, amounting to some 30 to 40 per cent of their previous incomes. The corporation had formerly supplied the workers with free housing, water, electricity and medical facilities but from now on they would be obliged to make substantial contributions towards these services. The most draconian measure, however, was the introduction of a compulsory savings scheme, forcing workers to save at least 15 per cent of their basic wages to assist the corporation's recovery. It was not until 27 June 1997 that this agreement between the unions and management was abrogated and conditions of service existing before 1990 were restored. ${ }^{26}$

This managerial strategy for economic recovery was reinforced in 1989/90. The IMF- and World Bank-inspired SAP obliged the CDC management to sign a four-year performance contract (1989/90-1993/94) with the government, stipulating that the corporation achieve a set of objectives relating to plantation management, production costs, quantity and quality of output, and personnel productivity (Tedga 1990; Mama 1996). In return, the government was to write

25 See The Herald, 21-24 July 1994, p. 3 and The People's Voice, Vol. 3, No. 14, May 1994, pp. 1 and 3-8.

26 See report on meeting held on 27 June 1997 between CDC management and the presidents of the Agricultural Workers' Union, presented by the provincial delegate of labour and social insurance for the South West Province, Ebot Ayuk Charles, to the honourable minister of labour and social insurance in Yaoundé on 10 July 1997, in File MTPS/DPTPS/SWP/BU.22, CDC General Correspondence, Vol. 1, 1997. 
off some of the corporation's debts amounting to FCFA 9 billion and to exempt it from the payment of certain taxes. The various adjustment measures did bring some relief to the company's liquidity problems but, due to the continuing decline in commodity prices, its existence remained precarious. It was not until early 1994 that any prospect of economic recovery appeared. ${ }^{27}$ The devaluation of the CFA franc made CDC products more competitive on the world market and then, a few months later, the government surprisingly announced the privatisation of the corporation, which prompted vehement protests in Anglophone Cameroon.

\section{Anglophone opposition to CDC privatisation}

During the economic crisis there were frequent rumours in Anglophone Cameroon that the Biya government was hoping to privatise the CDC and sell it to French or Francophone interests. ${ }^{28}$ Although the government strongly denied such rumours, Anglophones remained on the alert, ready to act if their regional patrimony was threatened. This is a clear sign that they had lost all faith in the corrupt, authoritarian regime and were not prepared to tolerate any further attempts by the Francophone-dominated state to dismantle their cultural and economic heritage. They were particularly determined to keep control over the $\mathrm{CDC}$, the pride and economic lifeline of Anglophone Cameroon.

In 1992, for instance, it was rumoured that the French were about to take over the corporation. This occurred after the French CCCE, which had previously already invested FCFA 2 billion in the CDC, offered another FCFA 7 billion low-interest loan to the ailing company. Although this loan provided much-needed capital for investment purposes, the increased control by France over the CDC was highly resented by the Anglophone population who saw it as a first step towards the ultimate takeover of the corporation by the CCCE. When local newspapers subsequently reported that the CCCE wanted to take over the CDC oil-palm estates, there were again widespread protests in Anglophone Cameroon. SWELA in particular was engaged in several protest actions in 1992. In February it collected the signatures of persons agitating against the alleged impending sale of the CDC to French interests, and it petitioned the head of state and British government on the issue. SWELA cautioned the government against a unilateral decision on any future privatisation of the CDC. Any such move, it said, would require dialogue with all the parties concerned, namely the landowners, the workers and the beneficiaries for whom the CDC

27 For the current financial position of the corporation, see the CDC Annual Reports and Accounts for the Years 1995-2002, Bota: CDC Head Office.

28 See, for instance, The Messenger, Vol. 2, No. 4, 1992, pp. 1 and 4 and Cameroon Post, 11-18 February 1992. 
had been created in 1946. On 12 August 1992, SWELA organised demonstrations in the South West Province on the CDC issue. ${ }^{29}$

This outcry against expanded French control of the corporation contrasted sharply with Anglophone sentiments regarding transfers by the management of two major CDC crops to Anglo-American companies. Few protests were voiced in Anglophone Cameroon when the corporation entrusted the management of the banana sector to the American multinational Del Monte in 1987 (Fonsah \& Chidebelu 1995). And Anglophone newspapers even lauded the agreement between the CDC and COMDEV in February $1993^{30}$ that stipulated that management of the corporation's three tea estates be transferred to COMDEV for a period of ten years (Konings 1995a and b). Anglophones argued that these two Anglo-American companies had extensive experience in plantation management, and COMDEV even had experience in Anglophone Cameroon, having satisfactorily managed the CDC from 1960 to 1974. Above all, Anglophones strongly believed that Anglo-American companies would be less inclined than French ones to dominate and exploit an English-speaking region and that the Anglo-American business culture fitted in well in Anglophone Cameroon.

When the government did finally announce the privatisation on 15 July 1994, Anglophones were deeply incensed. It even appeared that the Anglophone minister of agriculture who was responsible for CDC matters, $\mathrm{Mr}$ Stephen Njinyam, had threatened to resign if the CDC were placed on the list of enterprises to be privatised. He was soon replaced by Mr A.F. Kodock, a Francophone, who had no scruples about privatising the CDC. ${ }^{31}$ While a few months earlier the South West-North West conflict had still divided Anglophones inside and outside the corporation (see above), all the existing parties, associations and pressure groups in Anglophone Cameroon now formed a united front to resist the government's decision. It would be wrong to conclude from this opposition that Anglophones were against privatisation per se. In fact, privatisation of poorly performing public enterprises has been included in the programmes of most Anglophone parties, including the SDF (see Konings 2001a). In a memorandum addressed to the head of state after the announced privatisation of the $\mathrm{CDC}$, which was co-signed by the various Anglophone pressure groups and Bakweri chiefs, it is equally stated that

29 See Cameroon Post, 11-18 February 1992, p. 5 and The Herald, 6-9 October 1992, p. 3 .

30 The agreement failed to function because of the government's inability to fulfil some of the conditions, notably the payment to COMDEV of £1 million (FCFA 450 million pre-devaluation) which was part of the debt owed to COMDEV.

${ }_{31}$ See Cameroon Post, 26 July-2 August 1994, p. 12 and La Nouvelle Expression, 26 July-1 August 1994, p. 12. 
in principle, the Bakweri and other Anglophones have no quarrel with the idea of privatisation or sale of companies in which government enjoys majority control since we fully understand the logic behind such an exercise, i.e. the relocation of the management of inefficiently managed parastatals in more efficient hands. We recognise that government, as the controlling shareholder in these companies, has an obligation to the majority shareholders and the Cameroonian taxpayers to ensure that their tax revenues are not wasted in failing parastatals. ${ }^{32}$

Anglophones, however, claimed that the CDC should have been excluded from this privatisation exercise for various reasons.

First, the CDC was one of the few remaining large-scale enterprises in Anglophone Cameroon still largely controlled by Anglophones. Many regional enterprises, such as the West Cameroon Electricity Corporation (Powercam), the Cameroon Bank, the West Cameroon Development Agency and the West Cameroon Produce Marketing Board, had all been systematically dissolved by the Francophone-dominated state after reunification (Mukong 1990; All Anglophone Conference 1993). Another leading regional agro-industrial enterprise, the Plantations Pamol du Cameroun Ltd, a Unilever subsidiary, decided in 1987 to go into liquidation after the government refused to provide it with similar bank and infrastructural facilities to those enjoyed by the agro-industrial parastatals. It was widely believed in Anglophone Cameroon that the principal reason for government refusal was to force a company with British connections to wind up its activities in the region. A Frenchman was appointed as liquidator but instead of selling the company to the highest bidder, he ran it as an on-going business for several years, earning himself a comfortable income in the meantime (Konings 1998). Another leading enterprise in Anglophone Cameroon, Sonara, the oil-refinery near Victoria (Limbe), could hardly be called a regional enterprise: its oil is transported through a gigantic pipeline to Douala and its managerial staff and workers are predominantly recruited among Francophones (Ndzana 1987; Ngu 1989; Jua 1993).

Second, the CDC was a unique enterprise in Cameroon and economically vital to Anglophone Cameroon. From its inception, it had been oriented not only to capital accumulation but also to regional development. One Anglophone columnist, Mr Jing Thomas Ayeh, captured the essence of what the CDC meant for Anglophones:

The CDC is unlike any other corporation. It means native lands, especially those of the Bakweri. It means jobs for Cameroonians, especially the Anglophones. It is a

32 For this memorandum, see Fako International, Vol. 1, No. 2, January 1995, p. 14. 
symbol of Anglophone survival against all odds... If the CDC falls ... the last act of internal colonialisation would have been completed. ${ }^{33}$

Third, unlike many other Cameroonian enterprises, the CDC had performed well until the economic crisis, and the announcement of its privatisation came at a time when there were good prospects for the corporation's economic recovery following the devaluation of the CFA franc.

Fourth. in accordance with the agreement between the management and the unions in 1990, the workers had injected FCFA 5.5 billion into the corporation as compulsory savings during the crisis. Therefore, the CDC could not be privatised without consulting the unions and workers. ${ }^{34}$

All the Anglophone movements, like the SCPC, CAM and the FWCM, were unanimous in their opposition to the announced privatisation of the CDC, which they regarded as 'a declaration of war against the people of Southern Cameroons by the Biya regime' ${ }^{35}$ and as 'a government ploy to hand over the profitable CDC to French interests' ${ }^{36}$ In a press release issued at the end of an extraordinary session in Buea on 23 July 1994, the SCNC warned 'France, French interests, French nationals and their Biya acolytes that we hold them jointly and separately responsible and liable for this recent scheme against our territory and our people', pointing out that 'the proposed privatisation ... is designed to transform the Southern Cameroons into an economic and industrial desert, and its people into perpetual slaves to France'. It called upon all Anglophone movements to engage in concerted action 'so as to settle this threat to our inheritance'. It also declared 16 August 1994 as CDC Solidarity Day, requesting that Southern Cameroonians mark this day by staying at home. ${ }^{37}$ Subsequently, there were protest marches in Anglophone towns organised by Anglophone movements and the SDF. Posters carried banners with slogans such as 'France: Hands off Anglophones' and 'Hands off or we will burn the plantations'. ${ }^{38}$

On 31 July 1994, SWELA, too, vehemently warned all investors, particularly the French, to stay clear of the corporation or 'meet with far-reaching consequences'. It stated that 'it totally rejected government design to re-

Cameroon Post, 26 July-2 August 1994, p. 12.

34 See, for instance, the statement of Mr C.P.N. Vewessee, president of the Fako Agricultural Workers' Union, in Cameroon Post, 6-13 September 1994, p. 9.

35 CAM Resolution, On the Privatization of the CDC, Bamenda, 31 July 1994 (mimeo).

36 Cameroon Post, 26 July-2 August 1994, p. 6.

37 Ibid.

${ }_{38}$ New African, No. 326, January 1995, p. 25 and Africa International, Nos. 279/280, January-February 1995, p. 39. 
colonise and dehumanise South Westerners in particular and Anglophones in general', and it strongly requested the government to revoke its decision forthwith. It invited all South Westerners 'to collaborate with any group that try to call for strikes and other forms of mass action intended to stop the privatisation'. In addition to 16 August, it declared 12 August as another CDC Solidarity Day. ${ }^{39}$ Although demonstrations organised by SWELA on 12 August were readily broken up or prevented by the police, a determined group of SWELA members led by their secretary-general, Mr Martin Nkemngu, marched successfully to the office of the South West Governor in Buea where they handed in a memorandum for the attention of the head of state..$^{40}$

Unsurprisingly, the most vehement opposition to the announced privatisation of the CDC came from the landowners, both in the South West and in the North West of Anglophone Cameroon.

The Bakweri in the South West Province, whose lands had been expropriated under German colonial rule and later leased to the CDC for a term of 60 years, felt particularly aggrieved. On 23 July 1994, the Bakweri chiefs and elite met in Buea under the chairmanship of Paramount Chief S.M.L. Endeley of Buea and Paramount Chief F. Bille Manga Williams of Victoria (Limbe) to discuss the implications of the government decision. They agreed to oppose the announced privatisation on the grounds that CDC lands were Bakweri lands and thus could not be sold to non-natives without Bakweri consent. ${ }^{41}$ After lengthy and passionate discussions, an ad hoc committee was elected by acclamation to prepare a detailed memorandum on the Bakweri position to be presented to the government and all other interested parties. ${ }^{42}$

On 4 August 1994, over 500 Bakweri elite and notables gathered at the Buea Youth Cultural and Animation Centre approved the memorandum drawn up by the ad hoc committee. They later presented it to the provincial governor for onward transmission to President Biya. On the same day, the eminent Bakweri scholar, Professor Ndiva Kofele-Kale, secretary of the ad hoc committee, was designated counsel for the Bakweri people with instructions to present their case before the United Nations and other international fora.

The Herald, 4-7 August 1994, p. 2.

Ibid.

${ }^{41}$ According to the Bakweri, the 1974 Land Law (Ordinance No. 74-1 of 6 July 1974 to establish rules governing land tenure) does in fact ground Bakweri land rights in positive law in its classification of all 'land tenured into the Grund Buch (the case with all CDC lands)' as 'land ... subject to the right of private property'. See BLCC, Open Letter to All Prospective Buyers of CDC Plantations, Buea, 12 October 2000. For the 1974 Land Law, see Republic of Cameroon (1981), Land Tenure and State Lands, Yaoundé: Imprimerie Nationale.

${ }^{42}$ Fako International, Vol. 1, No. 2, January 1995, pp. 14-16. 
The Bakweri case was emphatically supported by Anglophone movements. A strongly worded petition to the head of state, co-signed by the Anglophone movements and the Bakweri chiefs, reiterated that the Bakweri had never relinquished ownership of CDC lands and that the corporation could not be sold without Bakweri consent. It pointed out that the Bakweri had not been paid royalties for the use of their lands since the creation of the CDC in 1946. It also stressed that the Bakweri were not inclined to renew the 60-year CDC lease and wanted to reclaim CDC lands after its expiry in 2007.

Concerned about the mounting anger in the Anglophone region in general and the Bakweri community in particular, the Biya government decided to send a delegation of high-ranking Anglophone allies to the South West to appease the population. The delegation was led by Chief Ephraim Inoni, deputy secretary general at the presidency and Chief of Bakingili, a village located on the territory of a Bakweri subgroup. The delegation met a number of Bakweri representatives in Buea to discuss the land problem. Though speaking on behalf of the government, Chief Inoni appealed to the Bakweri representatives not to forget that he was one of them. He acknowledged that there should have been contact between the government and the Bakweri prior to the announcement of the corporation's privatisation but he denied the widespread rumours in Anglophone Cameroon that the French and some high-ranking Francophones had masterminded the whole operation. While admitting that the financial situation had improved after the devaluation of the CFA franc, he argued that privatisation would enable the corporation to obtain new capital for necessary investments in production and processing. The Bakweri Paramount Chief S.M.L. Endeley, who had always been a staunch supporter of the regime until the Bakweri land issue arose, then took the floor. Amid thunderous applause he declared that he, as the custodian of the ancestral lands, and the Bakweri population as a whole were against the privatisation of the CDC and requested that Chief Inoni report this to President Biya:

We are in a country where we like to cheat ourselves, where government hands decisions through dictatorship... We say no, no [to privatisation], go and tell $\mathrm{Mr}$ Biya that he cannot afford to go down in history as the man who sold the CDC. ${ }^{43}$

The delegation had an equally tough time when they met CDC workers at Tiko, Victoria (Limbe) and Kumba. They were jeered and questioned as to why Anglophones had been chosen to deliver the unhappy message of privatisation. Was it because they would benefit from the spoils? Workers requested they take

${ }^{43} \quad$ Ibid., p. 16. 
home one message to the government - that the CDC would be sold to the French only over their dead bodies. ${ }^{44}$

In the North West Province, the Wimbum of the Donga-Mantung Division, owners of the CDC Ndu Tea Estate (Konings 1995a), also strongly protested against the privatisation of the CDC. During a meeting in Bamenda on 22-24 July 1994, the Mbum Abi, the Wimbum People's Congress, resolved as follows:

We completely reject the proposed sale of this corporation around which the livelihood of all Anglophones revolves and depends... The people of Donga-Mantung in general and the Wimbum in particular shall not stand idly by and see the Ndu Tea Estate go. We shall resist with all our might!

In this light, we shall no longer lease our land to any person (moral or physical). Mbum Abi and the workers are prepared to take over the running of the estate.

Once more we launch a fervent appeal to all people of goodwill within and outside the country to rally behind us in this just cause. The CDC shall not go! ${ }^{45}$

Another Anglophone delegation headed by the North Westerner Peter Abety, minister for special duties at the presidency, was sent to Ndu by the Biya government to try to calm the population.

After these government delegations had returned to Yaoundé, the government took no further action with regard to CDC privatisation. However this apparent victory of Anglophone resistance turned out to be short lived. Particularly after 1997, rumours of an imminent privatisation of the CDC became more and more persistent. In conformity with the agreement concluded with the IMF and the World Bank within the framework of the Enhanced Structural Adjustment Programme (ESAP) in 1997, the privatisation of the CDC was soon expected to be launched. That the government, under severe pressure from the Bretton Woods institutions, was preparing the ground for the privatisation of the CDC could be deduced from the speeches and interviews of leading government and CDC officials at the opening ceremony of the corporation's golden jubilee celebration in Bota-Victoria on 1 December 1997. In his speech on that occasion, Prime Minister Peter Mafany Musonge, who still simultaneously occupied the post of CDC general manager, said:

Since the traditional international funding agencies no longer finance corporations like CDC, the establishment should be prepared ... to foster new business relationships to raise new money while the state plays the role of facilitator... Traditional rulers within CDC's areas of operation, workers and other Cameroonians must

44 See Cameroon Post, 29 August-5 September 1994, p. 4.

45 Cameroon Post, 26 July-2 August 1994, pp. 6-7. See also The Herald, $22-24$ August 1994, pp. 1-3 and La Nouvelle Expression, 26 July-1 August 1994, p. 12. 
understand perfectly well and make sure that peace reigns for conclusive investment. ${ }^{46}$

The CDC chairman, Mr N.N. Mbile, added that 'privatisation should not scare us as we are confident that government will protect the interests of the Cameroonian people, the original landowners, the workers, new investors and the state itself' ${ }^{47}$ Moreover, the CDC deputy general manager, Mr Richard Grey, then revealed that the reputable international consultancy firm, Coopers and Lybrand, had already been selected by the World Bank and the government to carry out a study on the privatisation of the CDC which would be completed by 30 June 1998. The Bakweri chiefs who attended the ceremony, notably Chief S.M.L. Endeley of Buea, were frustrated by these statements and revelations, and condemned any future privatisation.

The CDC was finally put up for sale in January 1999. Very little protest was heard from the now almost dormant Anglophone movements. Just a few weeks before his death on 10 April 1999, John Ngu Foncha and Ambassador (retired) Henry Fossung signed a strongly worded statement on behalf of the SCNC warning prospective buyers of the CDC to desist from investing in the purchase of the CDC. Traditional rulers and elite in the South West Province, however, quickly rallied again. In a meeting with southwestern members of parliament and government, they strongly denounced the privatisation of the CDC, saying that the latter's acceptance of the sale of the CDC 'was tantamount to a betrayal of their people'.$^{48}$ The Bakweri Land Claims Committee (BLCC) ${ }^{49}$ officially wrote to President Biya on behalf of the Bakweri people on 3 March 1999 requesting that it be included in the privatisation negotiations and that compensation be paid for the use of Bakweri lands. When rumours became widespread that multinational companies like Fruitiers/Dole, Chiquita and Del Monte were already negotiating with individual government officials about the purchase of the whole or parts of the CDC at throwaway prices, the Bakweri in the diaspora once again addressed the head of state on 1 October 1999 in support of the BLCC position..$^{50}$

Since no reply was forthcoming from the presidency, the BLCC, with much support from the Bakweri chiefs, SWECC and SWELA decided to start a highprofile public relations campaign involving the extensive sensitisation of national and international opinion through the writing of open letters, petitions

${ }^{46}$ The Post, 5 December 1997, pp. 1-2.

47 Ibid.

48 Isaha'a Boh Cameroon, Bulletin No. 405.

49 The BLCC is the revived Bakweri Land Committee founded in 1946.

50 See letter from the Bakweri around the world to President Paul Biya of Cameroon, dated 1 October 1999. 
and newspaper articles and the use of the Internet. The BLCC-USA in particular became very vocal, creating its own website on the Internet. ${ }^{51}$

In a letter to the managing director of the IMF, Mr Horst Köhler, on 16 June 2000 , the BLCC warned him about the growing unrest among the Bakweri and threatened legal action should the privatisation of the CDC be pursued without its involvement:

As the current impasse in Zimbabwe and Kenya demonstrate, land expropriated from African natives by European colonialists a century ago is the source of much contemporary unrest and instability. All Cameroonians of goodwill bear witness that the Bakweri people have over the years opted for a peaceful resolution of the CDC Bakweri land problem. However, should the privatisation of the CDC go ahead without the input of the Bakweri on whose land most of the corporation's agroindustrial activities are located, we preserve the right to seek legal redress against the government of the Republic of Cameroon, the IMF, the World Bank as well as all lessees who derive title to the land by whatever means, in any country of the world where such bodies are located. ${ }^{52}$

In a press release on 5 August 2000, the BLCC revealed that it was going to take its campaign for land restitution and compensation a notch higher by seeking consultative status within the United Nations Economic and Social Council (ECOSOC). It believed that the granting of such consultative status would provide it with a global platform to proclaim its struggle for land rights, 'bringing it into contact with other NGOs which claim to represent the interests of indigenous groups from around the world as well as with sympathetic UN members who have championed the cause of dispossessed people on the floor of the General Assembly and at the numerous ECOSOC meetings over the years'. Soon thereafter, on 21 August 2000, the counsel of the BLCC, Professor Ndiva Kofele-Kale, was invited by the United Nations to make a representation on the Bakweri lands issue to the UN Human Rights Commission in Geneva.

Following the government's renewed call for tenders for the sale of the CDC in September 2000, the BLCC cautioned prospective buyers in an open letter as follows:

It is our duty to advise you to think twice before you commit the resources of your shareholders in a venture that is still mired in controversy and whose promised financial and economic rewards may prove to be illusory in the long run..$^{53}$

${ }^{51}$ See http://www.bakwerilands.org. Most of the documents quoted in this section can be found on this website.

52 Letter from Dr Lyombe Eko, executive director of BLCC-USA, to Mr Horst Köhler, managing director of the IMF, dated 16 June 2000.

53 BLCC, An Open Letter to All Prospective Buyers of CDC Plantations, 12 October 2000. 
It soon became evident that the BLCC found it hard to defend Bakweri interests at a national level after 'their own son', Peter Mafany Musonge, had been appointed prime minister in 1996. It is beyond doubt that one of the main reasons for his appointment in this position was that President Biya regarded him, being an ex-CDC general manager and a Bakweri himself, as the most suitable candidate for handling the delicate issue of CDC privatisation.

The appointment of Musonge had initially raised high expectations among the Bakweri. They were convinced that 'their son' would pay particular attention to the land question and take Bakweri interests into consideration during the eventual sale of the CDC. Their expectations appeared to have a sound foundation because, in his former capacity as CDC general manager, Musonge had publicly declared during a radio interview in 1994 that any privatisation of the CDC should be 'not only economically effective but also socially equitable'. For that matter, the following groups should be directly involved in this endeavour: (i) the indigenous landowners; (ii) the workers; and (iii) the investors. Once appointed prime minister, however, he came under immense pressure from the IMF and his master, Paul Biya, to champion the economic advantages of CDC privatisation and to forget about the payment of any compensation to the Bakweri landowners. Unable to convince his ethnic group to give up its claim to what could possibly amount to tens of billions of CFA francs after more than fifty years of CDC existence, he is reported to have resorted to intimidation, using the Buea sub-prefect and the Fako prefect for such purposes.

In March 2000, the Buea sub-prefect banned a BLCC general assembly meeting for which he had earlier given approval. The prime minister appears to have quickly ordered a halt to the meeting when he learnt that compensation was high on the agenda, but he failed to intimidate the committee that had just elected a new executive composed of some of the most respected Bakweri elite such as Chief Peter Moky Efange (chairman) and Mola Njoh Litumbe (secretary-general). The committee was subsequently ordered by the Fako prefect, Jean-Robert Mengue Meka, to halt its activities, and it was accused of being an illegal organisation. Efange and Litumbe, in response, told Mengue Meka that he himself was acting illegally by claiming that the BLCC, which was founded as long ago as 1946, was an unlawful association. The prefect was reminded that the committee had been received by the South West governor in 1994 and could thus not now have its legality questioned.

Musonge and other senior southwestern government officials also tried to persuade the BLCC to curtail its ongoing national and international campaign, arguing that this campaign had resulted in the refusal of several multinational 
enterprises to submit tenders until the land issue had been resolved. ${ }^{54}$ During a meeting in October 2000, Musonge and Chief Ephraim Inoni, the Bakweri deputy secretary-general at the presidency, requested that BLCC leaders allow the process of CDC privatisation be completed before tackling the land issue. Through such manoeuvres, Musonge even succeeded, albeit temporarily, in dividing the BLCC into two camps: one radical faction led by Chief Efange which stood its ground, and one moderate faction led by the Bakweri Paramount Chief of Buea Sam Endeley that was more sensitive to Musonge's arguments. Later on, both factions agreed again that the government should recognise Bakweri ownership of CDC lands prior to any sale of the corporation and involve the BLCC in its actual sale.

Of late, some Anglophones, especially North Westerners, have blamed the BLCC for turning the privatisation of the CDC into an exclusively Bakweri affair. They stress that the BLCC has not been playing its cards well by ignoring the equally legitimate claims of the entire Anglophone community to the CDC. In September 2000, one of the most respected northwestern opinion leaders, N.N. Susungi, observed in this respect:

The United Nations Trusteeship Council resolution of March 1950 is very clear in its language that the $\mathrm{CDC}$ is the common property to the people of the British Trusteeship Territory of Southern Cameroons. The problem is that the BLCC has never accepted the principle that the CDC is the common property of the people of Southern Cameroons, because over the years the land and the company have come to signify one and the same thing to the BLCC. ${ }^{55}$

To protect both the general Anglophone and specific Bakweri interests in any future privatisation of the $\mathrm{CDC}$, he suggests the need for a common front. $\mathrm{He}$ is thus proposing to the BLCC that it spearhead the convening of a joint conference of North West and South West chiefs and parliamentarians. Such a conference of Anglophone representatives would discuss the consequences of the UN Trusteeship Council resolution of March 1950 for the current government's role in the privatisation of the CDC and to take a common stand on (i) the BLCC land compensation claims; and (ii) the use of the proceeds of the sale of the CDC. It is evident that Susungi's suggestions would greatly enhance the Anglophone bargaining position.

When the government announced in October 2002 that the CDC tea estates had been sold to Brobon Finex PTY, a South African consortium, a different reaction could be observed from the side of the BLCC and the Anglophone

${ }_{54}$ See Report of the SWECC Meeting on 27 January 2000 focused primarily on 'the question of privatisation of the CDC, and the role of the BLCC in relation thereto'.

55 See the intervention of N.N. Susungi on Scncforum, 25 September 2000. 
movements - a clear sign of disrespect for Susungi's call for Anglophone unity in respect of the CDC's privatisation.

The BLCC reiterated that it was not opposed to privatisation per se, being in agreement with the government that privatisation of the CDC estates could contribute to better management of the giant corporation, attract capital for the necessary investment in the corporation's modernisation, and lead to increased productivity. However, it expressed its 'total bewilderment' at the sale of the CDC estates without any consultation or compensation of the landowners in spite of previous deliberations between the government and the BLCC. It then resolved to resist the sale by all possible means, including legal proceedings. ${ }^{56}$

In sharp contrast to the BLCC, the SCNC claimed that the government of La République du Cameroun, which had unilaterally seceded from the union in 1984, had 'no locus standi whatsoever to privatise, sell or transfer the CDC Tole Tea Estate and the CDC Ndu Tea Estate located undisputably and exclusively within the territorial boundaries of the Southern Cameroons to the South African consortium Brobon Finex PTY or to any other person'. ${ }^{57}$ Like the BLCC, it threatened to resist the 'illegal deal' by all means possible.

\section{Conclusion}

Both the Anglophone demands for an autonomous GCE Board and their protests against the privatisation of the CDC basically originated from widespread concern among the local population about what had happened to its educational and economic legacy after reunification. Anglophones were no longer prepared to tolerate any further Francophone onslaught on their identity. Their initial successes, however, were largely undermined when internal divisions reappeared. The regime was then able to re-establish a large measure of control over the GCE Board. Strikingly, the government has not yet been able to sell the CDC. While the Anglophone movements, being increasingly paralysed by both leadership problems and government divisive and repressive tactics, have, since 1995, almost stopped protesting against the privatisation of the CDC, the Bakweri - the owners of the CDC lands - have not yet given up their resistance. The latter have launched a national and international campaign

56 See BSCNation, 13 June 2002, 'Statement by the BLCC following the Announcement on the Privatisation of the Tea Estates of the Cameroon Development Corporation'.

57 SCNC, 'Privatisation of the CDC or part thereof by La République du Cameroun is illegal and unacceptable', BSCNation, 1 November 2002. See also SCNC Press Release on CDC Privatisation, Bamenda, 24 October 2002. 
192

for the defence of their interests, insisting that the corporation cannot be sold without their consent and without them receiving compensation. 


\section{The Anglophone problem: impasse and suggestions for a solution}

In this book we have attempted to show how the Anglophone problem has become a major challenge to the post-colonial state's nation-state project that has continuously stressed the importance of national unity and national integration to the achievement of political stability and economic development. The various Anglophone movements that were created or reactivated during political liberalisation have been at the forefront of region-centred political protests and demands for the rearrangement of state power. In the first section of this concluding chapter we summarise the major findings of this study and argue that the relations between the Anglophone movements and the regime have been at an impasse since the mid-1990s. In the second section we suggest some proposals that might put an end to the existing stalemate and, hopefully, solve the Anglophone problem.

\section{Impasse in relations between the Anglophone movements} and the regime

The various Anglophone movements have made a significant contribution to raising Anglophone consciousness and have been able to put the Anglophone problem on the national and international political agenda. They have claimed that reunification, the federal constitution for a reunified Cameroon and the 
post-colonial nation-state project have been unwelcome and unfortunate events, being contrary to the aspirations, interests and assumed values of the Anglophone minority. Our study has shown that such claims are not without foundation.

The idea of reunification appears to have been much more popular among the Francophone population than among Anglophones in the southwestern quadrant. Its devoted and consistent flag-bearers were UPC loyalists and Francophone immigrants who converted some Anglophone leaders to the reunification doctrine. Significantly, the latter largely regarded the reunification idea in the first instance as an effective weapon to bring pressures to bear upon the British trusteeship administration to grant their territory either a larger measure of autonomy within the Nigerian Federation or separation from Nigeria altogether. Although the Southern Cameroons population ultimately voted by a majority of seven to three in favour of union with the former French Cameroon during the $1961 \mathrm{UN}$-organised plebiscite, there is overwhelming evidence to suggest that if a third alternative of either independence or continued trusteeship had been put forward, it would have been considered in a favourable light. Being deprived of this preferred option by the United Nations and with the complicity of the British, the Southern Cameroons population was given what amounted to Hobson's choice: independence by either joining Nigeria or reunification with the then independent Republic of Cameroon. The eventual vote in favour of reunification appeared to be more of a rejection of continuous ties with Nigeria than a vote for union with Francophone Cameroon. While most Southern Cameroonians dismissed outright integration into Nigeria because of the territory's previous neglect and domination by the Igbo under Nigerian colonial administration, they were also reluctant to join Francophone Cameroon fearing that reunification might entail domination by the Francophone majority and loss of their cultural heritage and identity. In the end, the majority of Anglophones opted for the lesser of the two evils because the ruling party in the Southern Cameroons, the KNDP, had assured them that the constitutional provisions for a reunified Cameroon would guarantee equality of both partners and the preservation of their cultural legacies. As Susungi (1991) aptly put it, the reunification episode was far from being the reunion of two prodigal sons who had been unjustly separated at birth but was more like a loveless marriage arranged by the United Nations between two people who hardly knew each other. Indeed, prior to reunification in 1961 the two Cameroonian communities had not only gone through two completely different colonial experiences but had lived longer apart than together in a body politic (Fombad 2001). Playwright and journalist Victor Epie Ngome captures this mismatch remarkably well in a play implying that the United Nations had no business bringing together What God Has Put Asunder (1992). The marriage 
has only subjected Anglophones to the whims and caprices of their Francophone overlords, whose imperial presidents have inspired other Anglophone playwrights to dream of Requiem for the Last Kaiser (Besong 1991), celebrate the end of the Dance of the Vampires (Butake 1999), and make Anglophones long for the day Palm-Wine Will Flow (Butake 1990) when recognition and representation of their expectations become reality.

By reuniting with the former French Cameroon, the Anglophone political elite had hoped to enter into a loose federal union as a way of protecting their territory's minority status and cultural heritage. However it soon became manifest that the Francophone political elite preferred instead a highly centralised, unitary state as a means of promoting national unity and economic development. This difference of opinion about the future form of state during constitutional talks for reunification was the beginning of a fierce and protracted struggle between Francophone unitarists and Anglophone federalists in Cameroon's constitutional history. While the Francophone elite received strong support from the French during the constitutional negotiations, the Anglophone elite was virtually abandoned by the British who deeply resented the Southern Cameroons option for reunification with Francophone Cameroon. As a result, Southern Cameroons, according to Charles de Gaulle, 'became a small gift of the Queen of England to France'. In the end, the Francophone elite was only prepared to accept a highly centralised federation that, moreover, was regarded merely as a transitional phase to the unitary state. Such a federation actually demanded relatively few amendments to the 1960 Constitution of the Republic of Cameroon. Interestingly, Pierre Messmer (1998: 134-35), one of the last French high commissioners in Cameroon and a close advisor of Ahidjo, points out that he and others knew at the time that the so-called federal constitution provided merely for 'a sham federation', which was 'safe for appearances, an annexation of West Cameroon'. Under the new constitution, West Cameroon lost most of the limited autonomy it had enjoyed as part of the Nigerian Federation. Even worse, a few months after reunification Ahidjo created a system of regional administration in which West Cameroon was designated as one of six regions, basically ignoring the federal character of the country. These regions were headed by powerful federal inspectors who, in the case of West Cameroon, in effect overshadowed the prime minister with whom they were in frequent conflict concerning jurisdiction. Besides, the West Cameroon government could barely function properly since it had to depend entirely on subventions from the federal government that controlled the major sources of revenue. When, in 1972, Ahidjo created a unitary state in blatant disregard of constitutional provisions, there was in reality little left of the federation except perhaps in name. What many considered as one of the last visible symbols of the 1961 union was removed in 1984 when Ahidjo's 
successor, Paul Biya, abolished the appellation 'United Republic of Cameroon' and replaced it with 'Republic of Cameroon', which significantly was the name the French-administered part of the country adopted when it became independent in 1960.

There appear to be sufficient grounds to justify the claim of the Anglophone movements that the nation-state project after reunification has been driven by the firm determination of the Francophone elite to dominate the Anglophone minority in the post-colonial state and to erase all cultural and institutional foundations of Anglophone identity. Various studies have shown that Anglophones have regularly been relegated to inferior positions in the national decision-making process and have been constantly underrepresented in ministerial as well as senior and middle-level positions in the administration, the military and parastatals (cf. Fonlon 1964; Kofele-Kale 1986; Takougang 1993). There is general agreement that the Anglophones have been exposed to a carefully considered policy aimed at eroding their language and institutions despite the fact that the Francophone political leaders had assured their Anglophone counterparts during the constitutional talks on reunification that the inherited colonial differences in language and institutions were to be respected in the bilingual union. And, last but not least, the relative underdevelopment of the Anglophone region shows that it has not benefited sufficiently from its rich economic resources, particularly oil.

Strikingly, the Anglophone movements have been inclined to lay all the blame for the Anglophone problem on the Francophone-dominated state and to gloss over the co-responsibility of the Anglophone elite who have dismally failed to form a united front in the pre- and post-reunification period for the representation and defence of Anglophone interests, being preoccupied with their own internal power struggles. Of course, their one-sided presentation of Francophones as 'exploiters and oppressors' and Anglophones as 'poor victims' has served first and foremost the purpose of mobilising the Anglophone population and advancing their goal of autonomy. By presenting their community as beyond impeachment and by making a golden age of the past, Anglophone movements have been able to harness uncritical support against 'Francophoneness' as a collective enemy.

Although the regime has often attempted to present the Anglophone movements as organisations that merely serve the interests of some disgruntled power-seekers, notably members of the Anglophone elite who have been in one way or another excluded from power in the national arena, their narrative of untold Anglophone suffering in the Francophone-dominated state appears to be widely supported by Anglophones irrespective of class, ethnicity, age and sex. Most Anglophones have multiple grievances about Francophone domination, assimilation and exploitation on the basis not only of their own personal 
experiences but also their frequent exposure to the sensitisation activities of Anglophone leaders, journalists and artists. Similar to the Anglophone movements, they are often inclined to compare their present predicament with an idealised colonial past. The older generation, born in the colonial era, often transmits to the youth the myth or nostalgia for the good old days when there was political pluralism, good governance based on principles of representation, transparency and accountability, and high moral standards in society. Compared to this imagined colonial paradise, the post-reunification era is bound to appear unattractive to Anglophones who have been confronted with unprecedented state violence in the wake of the extension of the brutal campaign against the UPC to their region, manifest in the frequent occurrence of various forms of intimidation and repression like arbitrary arrests, beatings and torture of socalled subversive elements and even peaceful civilians by police and gendarmes, widespread corruption and bureaucratic incompetence as a result of the over-centralisation of administrative authority, and economic mismanagement leading to a breakdown in public services and infrastructure as well as growing impoverishment. Anglophones are often inclined to attribute such vices to French traditions, values and institutions inherited by the Francophonedominated state. Daily encounters with the predominantly Francophone administrators and security officers in their own region, many of whom have no even basic knowledge of English, give them the impression of complete loss of power over Anglophone space (Eyoh 1998a: 165-66). That such encounters are traumatic is best evidenced by how rural pottery in the Ndop plains of the Bamenda Grassfields has sought to domesticate or neutralise gendarmes and military officials as vehicles of state repression, through the mass production of their figures for public consumption by potential victims of the brutality they bring.

The first years of political liberalisation raised high expectations among the Anglophones of an imminent change in the regime and a reconfiguration of state power in their favour. The corrupt and authoritarian Biya regime had been seriously weakened during the deepening economic and political crisis, having lost legitimacy among the vast majority of the population. The enormous expansion of the SDF and the emergence of several Anglophone organisations strengthened the conviction of a growing number of Anglophones that the regime could be forced either to hand over power to the SDF or to make farreaching concessions including the granting of Anglophone autonomy. By the end of 1991, the SDF and other opposition parties succeeded in forcing the Biya regime to accept constitutional reform and Anglophones immediately started demanding the dismantlement of the unitary state and a return to federalism. Biya's alleged 'theft of Fru Ndi's victory' in the fraudulent 1992 presidential election was a traumatic experience for Anglophones. Nevertheless, it 
reinforced their feelings that the regime, supported by France, would do everything to prevent an Anglophone from seizing power. This made them even more determined to achieve autonomy.

Given these circumstances, it is not surprising that the Anglophone movements had their heydays during this era. Under a capable and committed leadership, they organised frequent meetings, rallies, strikes, demonstrations and boycotts throughout the Anglophone territory and started a diplomatic offensive to acquire international recognition for their cause. Major achievements were the organisation of AAC I and AAC II attended by a large number of the Anglophone elite, which put first federalism and later secession on the constitutional reform agenda. Some important though temporary victories were booked in this period, in particular the creation of a GCE Board and the postponement of the CDC privatisation. On these occasions, the leadership was capable of mobilising Anglophones against government encroachment on their educational and economic legacies. Widespread euphoria could be observed in Anglophone Cameroon when the SCNC delegation returned from the United Nations in 1995 announcing that independence was only a matter of time.

From the mid-1990s onwards, the situation changed dramatically, with the Anglophone movements rapidly losing their initial momentum. Two main factors appear to be responsible for this unfortunate development: first, the apparent ability of the government to regain control over political events in the country and to contain the Anglophone threat; and second, the complex of internal problems faced by the Anglophone movements.

The government proved increasingly capable of neutralising the opposition parties and the Anglophone movements to a large extent by employing a number of long-standing tactics including divide-and-rule, co-opting party and ethno-regional leaders in the regime, and severe repression. Its major strategy was to divide the Anglophone elite by capitalising on existing rivalries between the South West and North West elite. Feeling dominated by the North West elite in numerical, economic and political terms, most of the South West elite are inclined to explain and solve the Anglophone problem in a way different from the Anglophone movements: they tend to make the North West elite, who led the Anglophone territory to reunification and controlled power in the federated state of West Cameroon, co-responsible for the current Anglophone predicament and propose a ten-state federation so as to forestall renewed North West domination in a future federal state. The government has found it increasingly rewarding to tempt the South West elite away from Anglophone solidarity with strategic appointments and the idea that the North West elite rather than the Francophone-dominated state is their major enemy (cf. Eyoh 1998a; Mbile 2000). Following the 1996 constitution that provided state protection to autochthonous minorities, it became instrumental in cementing an 
alliance between the South West elite and the ethnically-related Francophone coastal elite, the so-called Grand Sawa Movement - an alliance that appears to transcend the Francophone-Anglophone divide. In addition to its divisive strategies, the government has enhanced its repressive tactics after the SCNC's adoption of a secessionist programme.

A series of closely related problems has also contributed to the dramatic backdrop in the Anglophone struggle for autonomy. First, there is the problem of leadership. Since the resignation of the founding fathers (Sam Ekontang Elad, Simon Munzu and Carlson Anywange) from the leadership, the SCNC has lacked competent and committed leadership. The SCNC became almost dormant under their successor, Ambassador (retired) Henry Fossung. A poorly orchestrated attempt in 1998 to replace him with Prince Ndoki Mukete led to a factionalisation of the leadership. The two leaders appeared to be more concerned with contesting each other's position of power than promoting the Anglophone cause. An indication of their lack of commitment was their attitude to the proclamation of the restoration of the sovereignty and independence of the Southern Cameroons by Justice Fred Alobwede Ebong on 30 December 1999. Both not only dissociated themselves from this action but also resigned from the SCNC leadership.

Second, there is the problem of regular disunity among the various Anglophone organisations and ambiguity in their objectives. Subsidiary organisations like the Free West Cameroon Movement (FWCM), the Ambazonian Movement (AM), the Southern Cameroons Restoration Movement (SCARM) and the Southern Cameroons Youth League (SCYL) often develop objectives and strategies different from the umbrella organisation, the SCNC. Whilst most of them nowadays champion in various ways the independence of the Southern Cameroons, some appear never to have altogether dropped the idea of a return to a federal state. This ambivalence tends to create confusion among the Anglophone population. In June 2001, four of these organisations - namely the SCNC, the AM, the SCARM and SCYL - agreed to form an alliance to achieve the independence of the Ex-British Southern Cameroons. Strikingly, the AM immediately withdrew from the alliance when its leader, Fon Gorji Dinka, was not elected as head of the British Southern Cameroons Provisional Administration.

Third, there is the problem of strategy. Although the government has persistently refused to start negotiations about either a return to a federal state or peaceful separation, the SCNC has never been prepared to drop its motto of 'the force of argument' and adopt a more confrontational strategy or even armed struggle as propagated by the SCYL. Such a strategy is unlikely to bring about a change in government position or international recognition. There is ample evidence that appeals and petitions of separatist movements to the United 
Nations, the Commonwealth, the OAU and other international organisations are usually ineffective since these organs tend to respect the sovereignty and territorial integrity of their member states. The case of Eritrea is a clear example. The right to Eritrean self-determination was never recognised despite the fact that the Eritreans had an excellent case for self-rule based on the abrogation of international agreements by successive governments in Addis Ababa and the fact that they had physical control over at least some of the land they claimed. Instead, Eritrea was recognised as an independent state once a military victory had been won over the government in Addis Ababa, the traditional way that international society recognises new states. Moreover, with their tendency to make the entire Francophone community responsible for the Anglophone predicament, the Anglophone movements have managed to alienate even Francophones who have shown sympathy for their cause. Obviously, this tendency tends to be harmful to their planning of viable strategies for the achievement of their objectives and the formation of alliances with Francophone groups that sympathise with the Anglophone cause.

However, it would be a grave error to assume that the Anglophone movements have become fully paralysed or even defeated by divisive and repressive government tactics and their own organisational and strategic shortcomings. Following the proclamation of the restoration of the sovereignty and independence of the Ex-British Southern Cameroons by Justice Fred Alobwede Ebong on 30 December 1999 and the subsequent nomination of a provisional government, the Anglophone struggle appears to have acquired a new impetus. Moreover, the new SCNC leadership appears to have adopted a more radical posture in the face of oppression. One of its boldest initiatives was the organisation of the celebrations of the $40^{\text {th }}$ anniversary of independence of the Southern Cameroons on 1 October 2001. Despite government orders banning all demonstrations throughout the Anglophone region, a considerable number of SCNC activists decided to march on that day in the North West Province, defying the massive presence of police and armed forces. At Kumbo, five peaceful demonstrators were killed and many injured. Over 200 SCNC activists were arrested in Bamenda and elsewhere, including the new leaders. Remarkably, when Anglophone magistrates eventually ordered the release of the detainees, court orders were flouted by the regime. In addition to the tragic events in Kumbo, the government's gross lack of respect for the Anglophone courts was another shocking experience for Anglophones.

In 2001, the Ex-British Southern Cameroons Provisional Administration created a new body, the Southern Cameroons People's Organisation (SCAPO), for the specific purpose of pursuing legal avenues to address 'the claims of the peoples of Southern Cameroons to self-determination and independence from $\mathrm{La}$ République du Cameroun'. SCAPO, led by the SCNC chairman and chancellor of 
the provisional administration Dr Martin Luma, and Dr Kevin Gumne, rapidly filed a lawsuit against the Nigerian government in the Federal High Court in Abuja 'for the purpose of obtaining judicial relief to restrain the government of the Federal Republic of Nigeria from treating or continuing to treat or regard the Southern Cameroons or the people of that territory as an integral part of La République du Cameroun'. ' SCAPO had two reasons for taking Nigeria to court in its legal battles for the recognition of an independent Southern Cameroons state. First, the trust territory of Southern Cameroons had been administered by Britain as an integral part of Nigeria. Consequently, SCAPO was inclined to regard Nigeria as a co-conspirator with Britain in the process that led to the annexation of the Southern Cameroons by La République du Cameroun. Second, Nigeria had ratified the OAU Banjul Charter of Human Rights that lays down in Article 20 the right of all colonised or oppressed people to free themselves from the bonds of domination by resorting to any means recognised by the international community.

In the end, SCAPO scored a landmark victory when, in March 2002, the Nigerian Federal High Court ruled that 'the Federal Republic of Nigeria shall be compelled to place before the ICJ and the UN General Assembly and ensure diligent persecution to the conclusion the claims of the peoples of Southern Cameroons to self-determination and their declaration of independence'. It also placed a perpetual injunction, restraining 'the government of the Federal Republic of Nigeria from treating the Southern Cameroons and all the peoples of the territory as an integral part of La République du Cameroun'. ${ }^{2}$ This ruling may pave the way for international recognition of the Anglophone struggle for the creation of an independent state.

Significantly, owing to these and previous events, an increasing number of the Anglophone and Francophone CPDM elite now acknowledge, after long years of public denial, that there is indeed an Anglophone problem. In January 1999, Biya for the first time admitted, albeit in a dismissive fashion, that such a problem existed, even if he perceived it as one promoted by a handful of hotheads and vandals. Still, he has not yet shown any interest in negotiations with the Anglophone movements in spite of regular appeals by Anglophone, Francophone and international dignitaries to solve the Anglophone problem through dialogue.

Another interesting development is that the youth, frustrated by the various strategies of containment of the Anglophone community's legitimate aspirations for recognition and representation, have turned to alternative channels for mobilisation and strategy. Increasingly, they are using the Internet as a vehicle to air their views on various aspects of their predicament, centring mostly on their

Cited in http://yahoo.groups.com/group/BSCNation/message/6830.

West Africa, 31 March 2002, p. 19. 
territory and community as having suffered from the gross mismanagement of a corrupt and inefficient Francophone-dominated state and government. Their Internet sites and discussion groups are created and managed by Anglophone youths mostly based in the diaspora, the United States in particular. Because of their influential nature, these mailing and discussion groups have attracted even the state, which has normally been indifferent in the past. Given the flexible nature of the Internet, the real identities of users can be hidden under ambiguous usernames, making provocative and fearless exchanges easier. The implication of these developments is that future negotiations on the Anglophone problem can afford to ignore neither the youth nor the diaspora.

\section{Suggestions for a solution to the Anglophone problem}

Given the current stalemate and the SCNC's continuous adherence to its motto of 'the force of argument and not the argument of force', it would appear that future negotiations between the Anglophone and Francophone elites, like the 1961 constitutional talks in Foumban, are the most likely way of solving the Anglophone problem. Increasing numbers of the Anglophone and Francophone elite are beginning to support a negotiated solution.

A major opportunity to lay the long-standing Anglophone problem to rest was missed during the constitutional reform debate in the 1991-96 period when the Anglophone elite proposed a return to the federal state and even drew up a federal draft constitution. At the end of this process, which was fully controlled by the government, the 1996 constitution introduced a new classification of Cameroonians: those who belong to autochthonous minorities and those who do not. No attempt was made to define this bizarre concept but the Anglophone minority problem was carefully fudged. This attempt by the regime to reconceptualise 'belonging' was obviously aimed at safeguarding its survival. Finding it hard to win free and fair elections in the new multi-party system and to meet the Anglophone challenge to the unitary state, it felt obliged to encourage the resurgence of local identities which were likely to support its continued stay in power and to stretch the conventional ideas of minorities to such ambiguous proportions that historical minorities like the Anglophones were denied minority status in the 1996 constitution (Konings \& Nyamnjoh 2000).

It has become increasingly evident that Biya forms the major obstacle to the multiple calls for negotiations between the Anglophone and Francophone elite. As recently as December 2001, he declared in his New Year message that it would be a betrayal of the founding fathers of nation-building to make any concessions to forces seeking secession or the fragmentation of Cameroon. He 
appears not yet to realise that his present strategies of appointing a few Anglophones in strategic positions previously reserved for Francophones and brutalising the Anglophone movement are more likely to radicalise Anglophone demands than offer a lasting solution to the problem. The emergence of the SCYL with its advocacy of armed struggle, the election of a new and apparently bolder SCNC leadership, and the heated discussions of the Anglophones in the diaspora on the Internet furnish proof for possible radicalisation. At present, the gap between the Biya camp and the Anglophone leadership is so wide that there are no political or religious leaders in the country who command enough trust among both sides to be able to serve as credible intermediaries or facilitators of any discussion on the sensitive Anglophone problem. That is why the Anglophone leadership strongly believes that no meaningful dialogue is possible without the involvement of the United Nations, the supervisory organ of the former Cameroon trust territories. During his visit to Cameroon in May 2000, the UN Secretary-General Kofi Annan pleaded for dialogue between the Anglophone and Francophone leaders. To forestall any further bloodshed and an escalation of the conflict between the Anglophone movements and the Francophone-dominated state, he should bring more pressure to bear upon Biya to accept dialogue and help organise constitutional talks under the auspices of the United Nations.

Unlike the constitutional talks in Foumban in 1961, it would be advisable that, prior to the negotiations, the Anglophone and Francophone populations were to be actively involved in the constitutional process about the future form of state and eventually consulted in a referendum. We have stressed in this book that Anglophones and Francophones are by no means monolithic blocs. Both are divided along various lines, including ethno-regional ones (for example, the South West-North West divide in Anglophone Cameroon and the BamilekeBeti divide in Francophone Cameroon), political ones (supporters and opponents of the regime), and constitutional ones (different opinions about the future form of state).

During the actual negotiations, the various options for a future form of state are to be discussed freely and frankly. The major options appear to be the following:

- The formation of two independent states. The Anglophone call for an independent state has a long tradition. It was the most popular option in the Southern Cameroons in the years preceding reunification but the local population was eventually not given the chance by the United Nations to vote for it during the 1961 plebiscite. The Anglophone movements renewed this call during political liberalisation in the early 1990s. Contrary to the prereunification period, the renewed pursuit of an independent state was 
initially a minority option with most Anglophone movements striving for a return to a federal state. It was only after Biya's persistent refusal to discuss the federal option that the leadership of the Anglophone movements started championing a non-violent separation between Anglophone and Francophone Cameroon into two sovereign states along the lines of what happened between the Czechs and Slovaks in 1992. Such a peaceful separation would be accompanied by an equitable sharing of assets and liabilities, and perhaps supported by the establishment of other cross-border confidence-building institutions. Most leaders of the Anglophone movements now argue that this solution possibly holds the best chance for peace in the long run because any attempts to engage belatedly in democratic and institutional reforms just to placate the Anglophones and preserve international appearances may only prolong the agony of the Anglophones and postpone the day of reckoning. An increasing number of scholars like Ghai (1998) and Sandbrook (2000) also regard secession as the best solution in cases where there are no prospects for any peaceful coexistence of territorial units within dysfunctional and deeply divided nation-states. Eritrea's peaceful separation from Ethiopia in 1994 following a referendum the previous year reassured those who feared that secession in any African country would open a Pandora's box of violence and fragmentation.

The question, however, arises of whether there is sufficient support for the Anglophone movements' call for the creation of an independent Southern Cameroons state. They themselves claim widespread support in the Anglophone region, often referring to the 1996 signature referendum. Since there are several indications that the results of this referendum were clearly biased, a new referendum held under UN supervision would form a more reliable source of information about the Anglophone population's aspirations. Our own research instead provides evidence that the majority of the Anglophone elite tends to favour a federation, albeit differing on the number of states. Even some SCNC leaders, like the late John Ngu Foncha and the late Solomon Tandeng Muna (the Anglophone architects of reunification), appear never to have abandoned their federalist ideal although they continued to support the SCNC line in public for strategic reasons.

It is, however, unlikely that the Anglophone movements' call for an independent Southern Cameroons state will receive any support from the Francophone elite and the international community. The majority of the Francophone elite is clearly in favour of a decentralised unitary state and is determined to keep control of Anglophone Cameroon's rich natural resources, in particular oil. International organisations continue to respect the territorial integrity of member states and to disapprove of any move towards a further Balkanisation of Africa. That is why, during his recent 
visit to Cameroon, the UN Secretary-General Kofi Annan made the Anglophone movements understand, in no uncertain terms, that dialogue and reconciliation rather than separation were instrumental in solving the Anglophone problem.

The question of the fiscal prospects of an independent Southern Cameroons state deserves more attention to justify the SCNC's pursuit of independence. The same question was posed in the period preceding reunification and the then existing British doubts about the economic viability of a tiny independent Southern Cameroons state turned out to be one of the main reasons for the UN's refusal to consider this option. The area has in the meantime become the country's breadbasket and the source of its considerable oil wealth and a detailed study of the post-colonial Southern Cameroonian economy is needed to re-assess the economic viability of an independent Southern Cameroons state.

- A return to the federal state. Since the formal dismantlement of the sham federation in 1972, federalism has been rejected by the regime as alien and synonymous with fragmentation and secession. However, more than forty years of centralisation has not brought about the declared goals of national unity and integration, or economic progress. Why not start an experiment in true federalism, requiring among other things, the transfer of power to a lower level of jurisdiction with clear geographical boundaries, a legal status, specified functions, fixed financial resources and autonomous personnel. Of course, federalism per se offers no magic and ultimate solution to the Anglophone problem but properly conceived and implemented it might enhance the chances of regulating deep divisions within society and prevent them spilling over into inter-communal violence. The past fifty years have witnessed a federalist revolution. According to one estimate, nearly 40 per cent of the world's population now live within polities that are partly federal, and another third in polities that apply federal arrangements in some way (Fombad 2001). The seeming viability and durability of the Nigerian federal experiment in the face of severe odds has turned the country into an important reference point of constitutional efforts to engineer unity and peace in Cameroon and other deeply divided societies on the African continent (cf. Suberu 1999). At the same time, however, the continuing Nigerian problem of developing criteria for the sharing of federal revenues requires us to devote ample attention to the economic implications of federalism (Olukoshi \& Agbu 1996). The 1961 federal constitution did not provide for any autonomous financial resources for the federated state of West Cameroon and this quickly became a source of fierce conflict between the West Cameroonian authorities and the federal government. The high 
costs of federalism later allegedly became a pretext for the central government in Cameroon to abolish the federation and to oppose the re-introduction of a federal state.

Secessionist tendencies may disappear in Anglophone Cameroon if the present situation is turned in the direction of federalism and Anglophones are constitutionally guaranteed equal status and the preservation of their language and cultural identity. Federalism is widely supported in Anglophone Cameroon but Anglophones clearly differ on the number of states there should be. The Anglophone movements used to propose a return to the two-state (Anglophone-Francophone) federation but in sharp contrast to the pre-1972 federal arrangement, they have devised a federal draft constitution that provides for true autonomy for the federated states and even for the provinces within the federated states. The South West elite in particular are proponents of the ten-state option that calls for radical decentralisation of power based on the current ten provincial administrative units. For them, multi-party electoral competition and advocacy of a return to a two-state federal arrangement amplify fears of the domination of 'their' political space by North Westerners (Eyoh 1998a). The major opposition party in the country, the North West-based SDF, proposes a four-state federation so as not to alienate its majority Francophone membership. Anglophone pursuit of a federal state is also backed by certain ethno-regional groups and opposition parties in Francophone Cameroon, albeit differing, like Anglophones, on the number of states.

- Regional decentralisation. Decentralisation within the unitary state is an option that has been supported by the vast majority of the Francophone elite and a small minority of the Anglophone elite from the very start of the constitutional reform process in 1991. At present, many appear to be disappointed by the decentralisation clauses laid down in the 1996 constitution and their actual implementation. While the constitution provides for the possibility of some deconcentration of powers through the creation of regional and local authorities, these provisions are stated in such dubious, obscure and circumlocutory language that it is doubtful if there were ever any serious intentions of implementing them (Fombad 2001). None of these so-called new institutions, like regional councils, have been established. Moreover, recent official statements by senior government officials, including the president, have called for the postponement of their implementation.

Some Francophone scholars, such as Olinga (1994) and Donfack (1998), are now proposing the introduction of regional states with larger powers than the regime has been willing to grant, occupying a middle position on 
the constitutional spectrum between decentralisation and federalism. The formation of such states that in their view form an adequate answer to the widespread desire for autonomy in both the Anglophone and Francophone parts of the country could be based on the ten existing provinces or on new constitutionally recognised regions. The latter makes it possible to recognise one Anglophone region. The creation of an Anglophone region could be even more acceptable to the Anglophone movement if given a special status on the grounds that the Anglophone population perceives itself as a distinct community defined by differences in official language and inherited colonial traditions of education, law, and public administration. Similar experiments have been tried in countries such as Canada where Quebec enjoys a special status, and in Spain.

Ultimately such constitutional talks can only succeed if the regime is prepared to abandon its Gallic centralist conception of the state and the participants are allowed to think constructively and imaginatively about the most suitable solution to the Anglophone problem. This also requires Anglophones knowing where their best interests lie and having leaders capable of articulating their community's concerns and aspirations. 



\section{6}

\section{Anglophone and Francophone responses to the views of the Anglophone movements}

The Anglophone movements are inclined to look upon the Anglophone and Francophone population as homogeneous blocs, with the Anglophones usually being seen as loyal supporters and Francophones as fierce opponents. In this chapter a more refined picture of reality is presented.

On the one hand, evidence is provided to substantiate the Anglophone movements' perception. Generally speaking, Anglophones support the grievances articulated by these movements and their call for a return to a federal state, in sharp contrast to Francophones who tend to deny the existence of an Anglophone problem and favour the creation of a decentralised unitary state. On the other hand, the internal divisions in both groups are highlighted. Anglophones are clearly divided on the number of states there should be within a future federal state. Some support the two-state option championed by the Anglophone movements, while others favour a four- or ten-state option. Significantly, a minority of Francophones tends to sympathise with the Anglophone cause and even supports the creation of a federal state, albeit differing, like the Anglophones, on the number of states within a future federal state.

Of late, the situation has become even more complicated. Following the SCNC's adoption of a secessionist stand, a growing number of Anglophones appear to support the achievement of an independent Southern Cameroons state. 
Moreover, some members of the Francophone elite have begun to demand a larger measure of decentralisation than the Francophone-dominated state is willing to concede.

\section{Anglophone views}

As already pointed out in previous chapters, the feeling of communal disadvantage has become widespread in Anglophone Cameroon in the aftermath of reunification. Most Anglophones claim that their region has become subject to recolonisation, the coloniser having merely changed colour, and that they are being treated as second-class citizens in their own country. They often tend blame not only the Francophone-dominated state for their predicament but also the Francophone population as a whole. This is not surprising since they are in almost daily confrontation with overbearing Francophone government officials and oppressive Francophone soldiers and structures both in the Francophone region and in their own region. A young, highly educated Anglophone woman interviewed by Eyoh (1998a: 263) expresses her frustration about the secondclass citizenship of Anglophones as follows:

No matter how bilingual you are, if you enter an office and demand something in French, because of your accent, the messenger may announce your arrival simply as 'une Anglo' or respond in a manner intended to mock. You know that stereotypes are a normal part of life in Cameroon and the world over. But the constant reminder that as an Anglophone you are different creates the impression that we are secondclass citizens. This is what irritates Anglophone elites. You can imagine the frustrations of older and less educated Anglophones who have to deal with a bureaucracy which operates mostly in French and state officials who are so rude to the people they are supposed to serve.

Again, a young Anglophone musician who returned to Cameroon in 2001 after a five-year stay in South Africa was shocked by the behaviour of one of the Francophone cashiers in a large bakery in Douala, feeling like a stranger in his own so-called bi-lingual country. When he wanted to pay, he received a cool reception: 'What do you want? Stop speaking English. We don't speak that language here. Return to where you come from, John Fru Ndi'.

There is ample evidence to illustrate the increase in the distrust between the two parties to the union since reunification. It is even manifest, for instance, in Cameroon's political grammar: in common parlance, Anglophones often refer to Francophones as 'frogs' while Francophones tend to refer to Anglophones as

$1 \quad$ Le Messager, 30 November 2001, p. 6. 
'Anglo-fools' or 'Biafrans'. By using the term Biafran, Francophones are expressing their strong belief that Anglophones are inclined to be secessionist. This led the Lord Mayor of Yaoundé, Emah Basile, to designate Anglophones as 'enemies in the house'. As such, they should either voluntarily 'go across our borders' as Mbombo Njoya, the former minister of territorial administration and present Sultan of Foumban, once remarked after the launch of the SDF in Bamenda in May 1990 or be chased away (Ngniman 1993: 51). Owing to Anglophone opposition to the Francophone-dominated state, Francophones are also often inclined to perceive Anglophones as being ungrateful. In a CRTV interview, Charles Assale, the first prime minister of East Cameroon, told the Anglophone population that the British built only one house on its territory, which they destroyed on the eve of their departure. Reunification with Francophone Cameroon brought about the level of development Anglophones currently enjoy. He also stated that the costs of the plebiscite campaign incurred by Foncha and his party were largely defrayed by Francophones. He further claimed that he himself was the one who personally handed over money for the West Cameroon budgetary envelope to Foncha. ${ }^{2}$ Assale's interview was repeatedly broadcasted by CRTV as proof of Francophone kindness and Anglophone ingratitude.

Stereotypes are commonplace in Cameroon to mark the assumed differences in values and attitudes between the two parties. In an article on Francophone 'Anglophobia', Ngome (1993: 28) provides some striking examples of such stereotyping:

Anglophones see Francophones as fundamentally fraudulent, superficial and given to bending rules: cheating of exams, jumping queues, rigging elections and so on (...). The Francophones are irked by what they see as the Anglophone air of selfrighteousness and intellectual superiority.

In his pamphlet The Path to Social Justice, Ngam Chia (1990: 2) stresses the Francophone 'neo-colonial' mentality that compares most unfavourably with Anglophone independent-mindedness:

The Francophone psycho-social background is neo-colonised and as such one must not expect them to be as independent-minded as the Anglophones. For instance, Anglophones see themselves as people who can live without depending on Britain and France for aid, but the Francophones do not even believe that they can run a simple administration in the Civil Service without the so-called expert directives from France. To blame them, nonetheless, is to undermine the deep French cultural alienation of East Cameroon.

2 Le Témoin, 3 June 1993, p. 12. 
Anglophone leaders, some of whom speak impeccable French, have made use of such stereotypes to highlight the seemingly insurmountable gap between Anglophones and Francophones that allegedly prevents both parties from living together peacefully in the union. Of course, this was helpful in rallying the Anglophone population behind them in their pursuit of autonomy, either in the form of a return to the federal state or outright secession.

Besides the various Anglophone organisations and political parties, some social groups in Anglophone Cameroon have played a significant role in sensitising the local population on Francophone domination and exploitation, and mobilising it in defence of its interests, particularly writers, journalists and church leaders.

Several Anglophone writers have identified with the Anglophone struggle and contributed greatly to raising Anglophone consciousness and action (Lyonga et al. 1993). Three of the most important are mentioned here. Bate Besong, Anglophone Cameroon's most versatile and charismatic playwright and poet, has always maintained that the Anglophone creative writer 'must arouse his Anglophone constituency from the apathy and despair into which it has sunk' and transform his writing into 'hand-grenades' to be used against Francophone oppressors (Ngwane 1993: 35). A cursory overview of his own writing leaves one in no doubt that Bate Besong has lived up to his own prescription. His Beasts of No Nation (1990) is a bitter indictment of the Francophone exploitation of the Anglophones who are reduced to 'night-soil men' (a metaphor for slavery). Throughout the play, the Francophones are presented as reckless destroyers of the nation because of their unbridled appetites and moral insensitivity. They are 'ravenous wolves' or 'roaring lions' seeking to devour all that crosses their path. They are 'locusts' who 'eat tons of green'. They are 'thieves of no nation' who belong to a secret cult of 'greed, grab and graft'. The exploited 'Anglos', however, are going to demand their full civil rights or, what the dramatist calls, their 'identification papers'. The narrator, a kind of priest who will lead the down-trodden Anglos to the New Jerusalem, makes it clear that they will have their freedom - perhaps a nation of their own - or death. And the leitmotiv that runs through the play is: 'A hero goes to war to die' (cf. Ako 2001).

Bole Butake in And Palm-Wine Will Flow (1990) uses the Grassfields Fon (chief) as a metaphor, an epitome of institutionalised corruption, greed and dictatorship in the country. He predicts participatory democracy for his people through a grassroots revolution. The presence of pro-democracy forces and imagery from the North West Province leaves the audience in no doubt about where Butake believes his revolution will start.

For his part, Epie Ngome in What God Has Put Asunder (1992) uses an extended marriage metaphor to denounce the unitary state system and to uphold 
the idea of a two-state federation for Anglophones and Francophones. It is the story of Weka, a child brought up in an orphanage under Reverend Gordon and Sister Sabeth. When Weka reaches marriageable age, two suitors ask for her hand in marriage. One is Mr Miché Garba and the other Mr Emeka, who grew up in the orphanage with Weka. Despite Emeka's solid claims over Weka as a childhood friend, Garba has his way, but Weka accepts him reluctantly. Weka soon discovers that Garba is no good: he maltreats and neglects her. He exploits the rich cocoa farm left by her father and squanders the money on his concubines. He does not tolerate her questioning attitude. When she can stand him no longer, Weka escapes with her children to her father's compound to rebuild his dilapidated house and their shattered lives. Garba pursues her there, threatening to forcefully take them back home to his house. Clearly, the marriage metaphor relates to the political union between Anglophone Cameroon and its Francophone counterpart, with Weka standing for the former West Cameroon, Emeka for Nigeria, and Garba for La République du Cameroun. Weka's parents represent the British government that relinquished responsibility over Southern Cameroons. Reverend Gordon and the orphanage stand for the United Nations trusteeship mandate over Southern Cameroons. Garba's neglectful but exploitative attitude towards Weka represents the attitude of the Francophone leadership towards Anglophone Cameroon, behaviour that has come to represent the central grievance in what Anglophones have identified as the 'Anglophone problem' in Cameroon (Nyamnjoh 1996e: 350-51; Ambanasom 1996: 218-22). The major suffering inflicted by Miché Garba on Weka symbolises the creation of the unitary state in 1972:

Once the festivities were over, he brought a fleet of trucks and bundled all my children and me out of our house. His drivers gathered all our stuff trampling and damaging many things etc ... and so he forced me to settle in with him. Since then, he has been forcing my children to learn his own mother tongue and to forget mine with which they grew up; I must abide by the customs of his clan, not mine, and ... in short he has simply been breathing down my neck since then (Ngome 1992: 53).

The ultimate social relevance of What God Has Put Asunder to the Anglophone community lies in the fact that it has contributed in no small way to the overall education of the Anglophones. Its metaphorical style has been especially relevant during a period when censorship and repression made it virtually impossible to speak the language of freedom and survive. For a long time under the Ahidjo regime for example, when it was quite possible to become a prisoner without having committed a crime (cf. Mukong 1985), Mind Searching (cf. Nyamnjoh 1991) was about the only freedom Anglophones had to contemplate their predicament. 
Anglophone drama written by these and other playwrights has been made accessible to the common man by various theatre groups including the Yaoundé Theater Troupe and the Flame Players (Doho 1996). They have not only played in Yaoundé and other Francophone towns but have also toured both Anglophone provinces. Some groups have even performed in Europe. Plays staged by the Mountain Mourners in Germany have contributed inordinately to bringing the Anglophone plight to international attention. ${ }^{3}$

The second group that has contributed immensely to Anglophone awakening are the Anglophone journalists and columnists such as Charlie Ndichia, Boh Herbert, Julius Wamey, Sam Nuvala Fonkem, Joseph Bannavti, Jing Thomas Ayeh, Hilary B. Fohtung, Taadom Sultan, the Postman and Rotcod Gobata (Nyamnjoh 1996e: 351-56). Their journalism is very similar in language, style, theme and value assumptions to the creative writings of Bate Besong, Bole Butake and Epie Ngome. Like the plays and novels of the creative writers, this journalism deals with present Anglophone frustrations as well as memories of the glorious past: myths, legends and fairy tales of the good old days when the Southern Cameroons was still under British colonial rule. The impression is given of a formerly virtuous community now corrupted by unification with the Francophones, an essentially dishonest lot. These journalists are eager to expose the contradictions and inconsistencies in the policies and actions of the Francophone-dominated leadership of Cameroon and do not hesitate to recall the prereunification situation in Southern Cameroons marked, according to them, by transparency, accountability and selflessness in the management of public affairs.

Church leaders form the third group that has played a significant educational role in Anglophone Cameroon. Discussion here is restricted to the leaders of the three major mainstream Christian churches in Anglophone Cameroon, namely the Roman Catholic Church (RCC), the Presbyterian Church in Cameroon (PCC) and the Cameroon Baptist Convention (CBC).

It is noteworthy that the RCC is well represented in both the Anglophone and Francophone parts of the country, in sharp contrast to the PCC and CBC, which have their main bases in Anglophone Cameroon. In fact, the RCC is the dominant Christian church in the Beti region of Francophone Cameroon, the region of the ethnic group in power (Ngongo 1982; Mveng 1990). As a result, the Biya government expected the RCC to maintain cordial relations with the state. Some of the leading Beti ideologues of the regime, like Professor Mono Ndjana, even pleaded for the RCC and the state to fuse (Pokam 1987). Indeed, until political liberalisation in 1990, the RCC leaders broadly identified with the

3 The Post, 2 March 2001, p. 3. 
regime. The Archbishop of Yaoundé, Jean Zoa, himself a Beti, became the personification of the entente between the church and the regime in this period.

Although the RCC leaders usually attempted to present a united front in public, one could nevertheless observe from time to time internal divisions along ethno-regional lines, in particular between Anglophones and Francophones. The consecration in 1988 of the Anglophone Archbishop of Garoua, Christian Tumi, as the first Cameroonian cardinal appears not to have been well received by the Archbishop of Yaoundé who had been the leading figure in the $\mathrm{RCC}$ in the post-reunification period. It also sparked off much acrimony and discontent among Francophone Catholics, in particular in the Beti region. In a recent interview, in which he once again pointed at the exclusion of Anglophones from real positions of power in the Francophone-dominated state, Cardinal Tumi remarked that 'were it the prerogative of Cameroonians to choose a cardinal, he would not have been the one'. ${ }^{4}$ Another conflict between the two church leaders occurred in March 1990, when a CPDM-organised march against a precipitate introduction of liberal democracy ended with a mass in Yaoundé cathedral. This mass, which according to the CPDM organisers was intended 'to pray for peace', was celebrated by Jean Zoa. The media and the opposition, however, immediately interpreted this event as an expression of the archbishop's support for the regime and the one-party system. In an interview given after the event, Cardinal Tumi seemed to agree with this interpretation, stating that he himself would never have officiated at such a service. Obviously irritated by the cardinal's statement, Jean Zoa accused him of interfering in matters of the Yaoundé archdiocese that were not within his jurisdiction (Nwel 1995: 172).

Strikingly, the appointment in February 1987 of a Bamileke priest as auxiliary bishop in the Douala diocese gave rise to vehement protests from the autochthonous Douala priests against the Vatican's refusal to elevate one of the many qualified indigenous priests to this high position and the alleged domination of the church hierarchy by the ethnically-related Francophone and Anglophone Grassfielders. ${ }^{5}$ A similar event occurred in Yaoundé in 1999 when the autochthonous Beti priests and elite protested against the appointment of a Bamileke bishop, André Wouking, as successor to Archbishop Jean Zoa who had died in 1998. ${ }^{6}$ Apparently the autochthonous Douala and Beti clergy and elite were determined to forestall an extension of alleged 'Anglo-Bami'

4 The Herald, 28-29 November 2001, pp. 1 and 3.

5 The Vatican-addressed memorandum of the Douala priests on these issues can be found in Politique Africaine 35: 85-96.

6 For Beti reactions to his appointment as Archbishop of Yaoundé, see, for instance, Cameroon Tribune, 19 July 1999, pp. 8-9 and La Nouvelle Expression, 21 July 1999, p. 6. 
domination ${ }^{7}$ from the economic and political domains to the religious domain (see Chapter 5).

Following political liberalisation in 1990, both Francophone and Anglophone bishops became increasingly critical of the regime. The National Episcopal Conference of Cameroon issued a number of pastoral letters in which it held the regime largely responsible for the deepening economic and political crisis manifest in the growing impoverishment of the population, widespread corruption, intensification of ethno-regional tensions and conflicts, and violation of human rights. In addition, the Anglophone hierarchy, especially Cardinal Tumi and Paul Verdzekov, Archbishop of Bamenda, regularly expressed their views on issues of Anglophone concern. As such, they became frequent targets of vehement government attacks.

After his transfer from the distant archdiocese of Garoua to the archdiocese of Douala in 1991, Cardinal Tumi soon became one of the most notable figures in public life, constantly being tipped as a potential chairman whenever a national forum on politics or the constitution seemed imminent. Two events in 1994 exemplified his continuing defence of Anglophone interests. In February 1994, he publicly declared that he favoured federalism, citing diocesan autonomy in his own church and Swiss cantons as models. ${ }^{8}$ In December 1994, he, together with some other Anglophone leaders, withdrew from the Consultative Committee on Constitutional Reform ordered by the Biya government (see Chapter 4). In an interview with the journal L'Effort Camerounais in 1996, ${ }^{9}$ he declared that the new (1996) constitution 'had not thoroughly examined the Anglophone problem which has become a national problem'. He added that, in the absence of any constitutional provision for the Anglophone problem, a new constitution would be required sooner or later.

Following a period of relative silence, Cardinal Tumi recently started to voice his opinions on national and Anglophone issues once again. Since the year 2000 he has called, like the SDF and other opposition parties, for the installation of an independent electoral commission, ${ }^{10}$ stressing that the Francophone-dominated state has never organised any fair and free elections since reunification. He has also strongly condemned the extra-judicial killings by Special Forces of between 500-1000 criminal suspects in Douala.

7 In the autochthony-allochthony discourse, the Beti and Doula are inclined to lump the Anglophones (and even more specifically the Anglophone Grassfielders) and Bamileke strangers together as 'Anglo-Bami' whom they perceive as supporters of the main opposition party, the SDF. (See Geschiere \& Nyamnjoh 2000 and Konings 2001b.)

8 Cameroon Post, 14-17 February 1994, p. 4.

$9 \quad$ L'Effort Camerounais, 24 February-8 March 1996, p. 3.

10 Jeune Afrique Economie, No. 317, 2-15 October 2000. 
Unsurprisingly, he was quickly accused by the government of lying, antipatriotism, tribalism, ambitions of becoming president, violation of the principle of separation between state and church, lack of respect for those who govern, and insidious attempts to turn Cameroonians and the international community away from the determined efforts and sacrifices made by the government to bail Cameroon out of its economic crisis and insecurity. During an interview with $L e$ Messager in November 2001, ${ }^{11}$ he declared that it was an understatement to say that Anglophones are marginalised since they have been simply silenced and abandoned in all aspects of public life following reunification. He called upon President Biya to enter into dialogue with the SCNC and implement regional autonomy as provided for in the 1996 constitution, claiming that the SCNC would become more militant if the government continued to ignore the plight of Anglophones.

Compared to Cardinal Tumi, Archbishop Verdzekov's demeanour appears quiet, but his convictions are equally direct and, therefore, contentious in the eyes of the government. During the state of emergency imposed by the regime on the North West Province after the fraudulent presidential election in 1992, Archbishop Verdzekov strongly criticised the government for the mass arrests and torture of SDF militants. Torture, he said, was a heritage of French colonialism but it had been intensified and extended to the Anglophone region after reunification (Eboussi Boulaga 1997a: 399). He subsequently hosted several RCC human rights groups in the 'Bishop's House'. In 'A Humble and Earnest Appeal' co-signed by the other Anglophone bishops, he urged Prime Minister Achidi Achu on 25 September 1993 to preserve autonomous Anglophone education (Nyamnjoh 1996a: 117-31). In 1993-1994, he and Bishop Pius Suh Awa of Buea allowed the Anglophone movements to hold AAC I and AAC II on church premises. In 1996, he said that he had no doubt that 'an unwritten policy of absorption and assimilation of Anglophones had been actively pursued, and Anglophones felt that only through Frenchification could they be accepted as bona fide Cameroonians'. ${ }^{2}$

Although the PCC and CBC are smaller and less influential churches in Cameroon, their leaders, too, have regularly acted as spokesmen for Anglophone grievances and demanded a return to the federal state. For example, in a memo presented to President Paul Biya during his visit to Buea on 27 December 1991, ${ }^{13}$ the PCC leaders expressed their support for the Anglophone

${ }^{11}$ Le Messager, 26 November 2001, pp. 5-8. See also The Herald, 28-29 November 2001, pp. 1 and 3.

12 Paul Verdzekov, Archbishop of Bamenda, 'A Talk at the Presentation of a Book Entitled The Cameroon GCE Crisis: A Test of Anglophone Solidarity', 1 July 1996.

13 This memo can be found in Nyansako-Ni-Nku 1993: 25. 
struggle and a return to the federal state as follows:

Our founding fathers established this country on the cornerstone of unity in diversity and bilingualism. But our experience of unification is that the Anglophones are being treated with benign neglect by all successive regimes since independence. Today the Anglophone Cameroonian has become terribly marginalised. Even the utterances of some leading Francophone Cameroonians only go to make the Anglophones feel unwelcome in their own country.

Thirty years after independence, Anglophones are still being contemptuously referred to as 'strangers'. Despite their competence, they are still for the most part only considered as second best in administrative and political appointments.

Thirty long years after independence, the entire Anglophone Cameroon is still backward, underdeveloped., and tottering on a very rudimentary economy. Yet the entire Anglophone territory is absolutely rich in natural resources, and we see these resources being exploited every day. In fact, the more they are plundered, the more our territory reclines into poverty.

Mr President, political systems are not static. In fact, they are supposed to evolve from one stage to another improving themselves in the process. Now we can confidently say that the unitary system has not been satisfactory at all. Consequently, we advocate the return to a federal system like most other liberal democratic societies today. The new federation should have a defined system of revenue allocation.

In 1994 the PCC welcomed the AAC II after security forces had prevented it from holding its meetings in the Roman Catholic cathedral in Bamenda. During the ghost town campaign, on 15 May 1991, the Cameroon Baptist Convention (CBC) leadership delivered a message to the prime minister supporting a sovereign national conference. It was quite pointed about an Anglophone university and a federation (Takougang \& Krieger 1998: 224-25).

Unlike the leadership of these three major mainstream Christian churches, the leaders of the Pentecostal and Charismatic churches in Anglophone Cameroon have never directly addressed the Anglophone problem. Their message of revivalism, proposing religion as an alternative source of salvation and God as the answer to the sensitivities of power and to moral decadence, appears nevertheless to be indirectly relevant to the Anglophone predicament. Directly or indirectly, therefore, all the churches have contributed to the advancement of the Anglophone cause. Many Anglophones look forward to their Sunday sermons when pastors and priests are at their best in highlighting the socio-political and economic problems facing their congregations, and in castigating officialdom for power without responsibility (cf. Wirba 1992, 1993).

While most Anglophones tend to support the grievances of the Anglophone movements about Francophone domination and their call for a federation, they disagree on the number of states in a future federal state. 
The Anglophone movements propose a two-state (Anglophone-Francophone) federation, though lately they have tended to advocate an independent Southern Cameroons state. One of the South West-based political parties, the Liberal Democratic Alliance (LDA), has always supported their position. This is not surprising since many LDA leaders, such as Barrister Sam Elad, Dr Simon Munzu, Ambassador (retired) Henry Fossung and Mola Njoh Litumbe acted simultaneously as SCNC leaders. What is peculiar to the LDA is that it tries to forestall North West domination in a future two-state federation or in an independent Southern Cameroons state.

The pro-CPDM elite and chiefs, particularly in the South West Province, propose a ten-state federation, considering it a guarantee against renewed North West domination - a position supported by another South West-based political party, the Conservative Republican Party (CRP) (Menthong 1998: 21).

Some Anglophone political parties champion a four-state federation. This used to be the position of the erstwhile South West-based National Democratic Party (NDP) of Ambassador (retired) Henry Fossung. In a 1992 party pamphlet, ${ }^{14}$ Fossung explains his party's choice for a four-state federation as follows:

The federal system in Cameroon is necessitated in the first place by the country's bicultural heritage with its two distinct Anglo-Saxon and Francophone cultures. However, for the purpose of balanced regional development and to redress the existing imbalance of the Francophone majority and the Anglophone minority (a legacy of our colonial heritage) a further division of the larger French-speaking territory into three separate states is proposed. Such a division should be on the lines of local socio-economic, cultural and geographical considerations.

The four federated states would be the Western Federated State composed of the South West and North West Provinces, the Midwest Federated State made up of the West and Littoral Provinces, the Southern Federated State consisting of the Centre, South and East Provinces, and the Northern Federated State including Adamaoua, North and Far North Provinces. The federal capital Yaoundé would have a special status to be referred to as the Federal Government Territory. Following his party's merger with Njoh Litumbe's Liberal Democratic Party (LDP) in 1993 to form the Liberal Democratic Alliance, Fossung was converted to the two-state federation, and after his election as SCNC chairman in 1996 he started to propagate an independent Southern Cameroons state. In the meantime, his original idea of a four-state federation had been taken up by the SDF.

14 See NDP, The New Cameroon as a Four-State Federation, Buea, 1992, pp. 10-11. 
The position of the SDF, by far the most important party in the Anglophone region, on the future form of state has been evolving since its foundation in 1990. It first championed a large measure of decentralisation within the unitary state. In its 1991 Proposals on Devolution of Power, the party attempted 'to put into concrete form and detail its avowed slogan of "Power to the People". By introducing a large measure of decentralisation, the party intended 'to put an end to the former system bedevilled by overcentralisation of decision-making with a huge bureaucracy at the centre', and 'to get the common people themselves directly involved in their own governance'.

Given its growing membership in Francophone Cameroon, particularly among the Bamileke, the party increasingly presented itself as a national rather than an Anglophone party and adopted an ambivalent attitude towards calls from the newly emerging Anglophone movements for a return to a two-state federation (see Chapter 4). Its leadership tried to avoid alienating either its Anglophone or its Francophone members but this was not an easy task. The party's Anglophone members tended to be simultaneously supporters of the Anglophone movements and were therefore inclined to bring pressure to bear upon the party leadership to insert federalism into the party programme - a move increasingly opposed by the party's Francophone members. Like most other Francophones, the latter tended to adhere to the preservation of the unitary state, often equating federalism with secession. They rightly pointed out that some of the party's basic documents, like the 1990 SDF Manifesto and the 1991 SDF Proposals on Devolution of Power stressed the importance of national unity, allowing only for a large measure of decentralisation within the unitary state. The Francophone position was even backed by some of the party's Anglophone leaders, notably by its founding secretary-general, Dr Siga Asanga. On some occasions, Asanga publicly stated that the party's embracement of the Anglophone cause and federalism would endanger its social-democratic ideology and national appeal. ${ }^{15}$ The issue became even more pertinent when the Francophone majority demanded a more equal representation in the still predominantly Anglophone party executive. Since the party chairman was an Anglophone, the Bamileke, who formed the largest part of the Francophone membership, claimed entitlement to the post of secretary-general that was second in the party's hierarchy.

The party chairman, John Fru Ndi, was under pressure from both sides to clarify his position on the growing Anglophone-Francophone divide in the party. Eventually, he appeared to yield to Anglophone pressure. He openly

15 See, for instance, Today, 20 March 1995, pp.1 and 5; and Weekly Post, 26-31 July 1995, p.4. For some detailed discussion of Asanga's opposition to the introduction of federalism into the party programme, see Konings 2001a. 
declared himself to be opposed to Francophone domination of the SDF since the party owed its existence to the courageous initiatives and sacrifices of Anglophones. He bluntly added that 'it was unacceptable that a Bamileke would ever become Secretary-General of the SDF' - a statement reminiscent of a similar declaration by Joseph Owona during his term as secretary-general at the presidency: 'A Bamileke as President? Never!' Fru Ndi's clarification reinforced Anglophone influence in the party's decision-making organs, but served to temper enthusiasm for the party among the Bamileke elite. At its Bafoussam Convention in July 1993 the SDF had already endorsed in principle the idea of a federal form of government. To appease the Francophones, the party refused to adopt the two-state federation as advocated by the Anglophone movements, leaving it instead to the people themselves to decide on the exact form of federation during a future sovereign national conference. Only one year later, on 22 August 1994, the SDF National Executive Committee modified the Bafoussam declaration of federalism. It now clearly opted for a four-state federation (an Anglophone state and three Francophone states as originally proposed by Fossung's NDP) and Fru Ndi himself became a member of the Southern Cameroons Advisory Council (see Chapter 4). Partly as a result of his disagreement with the party's endorsement of federalism, Secretary-General Siga Asanga was expelled from the party in 1995. A number of Bamileke and other Francophone party leaders also left the party voluntarily or forcibly. One of them, Dr Basil Kamdoum, then founded the Social Democratic Party (SDP) that was intended to form a social-democratic alternative to the SDF. However, it never really got off the ground, nor did the Social Democratic Forum created by Siga Asanga to protest his expulsion from the SDF.

The SCNC's adoption of a secessionist stand gave rise to repeated and sometimes serious conflicts with the SDF leadership. When SCNC leaders proposed boycotting the 1996 municipal elections, claiming that any elections called by the government of La République du Cameroun were irrelevant to an independent Southern Cameroons state, the SDF leadership refused to comply. Relations deteriorated after the proclamation of the restoration of the independence of the Federal Republic of Southern Cameroons (FRSC) by Justice Ebong on 30 December 1999. On 6 May 2000, the SDF National Executive Committee met to discuss the new developments on the Anglophone scene. During a stormy debate it decided to demand the resignation of some important party leaders. Dr Nfor Ngala Nfor, who used to be the chairman of the SDF Constitutional and Political Affairs Committee, was asked to resign because of his recent acceptance of the positions of vice-chairman of the SCNC and vicepresident of the FRSC. Dr Luma, the second vice-president of the SDF, was asked to resign because he chaired the historic meeting on 1 April 2000 during which Justice Ebong was proclaimed president of the FRSC and Dr Nfor Ngala 
Nfor was appointed as vice-president. Interestingly, this decision was later revoked on the grounds that Dr Luma had not yet accepted a leadership position in the SCNC and, above all, was one of the few South Westerners at the top of the party's hierarchy. Albert Mukong, a human rights activist and founding member of the SDF, was also asked to resign because of his persistent militancy in the Southern Cameroons cause (see Chapter 4). The departure of these persons is clear proof that the SDF leadership is determined to purge the party of 'extremist' and separatist elements in order to maintain the support of its Francophone membership. ${ }^{16}$ Another SDF founding father and former SCNC leader, Professor Carlson Anyangwe who is still working abroad, has also recently distanced himself from the party, identifying himself more closely with the SCNC struggle for an independent Southern Cameroons state. That the SDF leadership is under strong pressure from its Francophone membership to maintain a certain distance from the Anglophone separatist tendencies was manifested again in June 2000, when Mr Chrétien Tabetsing, a Bamileke member of the SDF living in France who failed to unseat John Fru Ndi as party chairman during the SDF's 1999 convention, called for the holding of an extraordinary convention. The purpose of this convention, he said, was to debate the Anglophone problem that had become a sensitive issue in Cameroon and was dividing the party into two opposing camps. He claimed that the SDF would disintegrate and cease to exist should Anglophone wishes prevail. ${ }^{17}$

On 7 May 2000, the chairman of the SDF, John Fru Ndi, openly confessed that his party was at variance with the SCNC over the strategic options for solving the Anglophone problem. While his own party continues to view a fourstate federation as a panacea for the Anglophone problem, the SCNC was, he lamented, beating the drums of outright secession. He strongly condemned some SCNC activists who were issuing threats against the SDF 'in a bid to persuade the party to dance to their independence song'. Instead of combating the Biya regime, the SCNC, he alleged, was now engaged in fighting the SDF. He blamed the SCNC authorities for 'cowardly staying away when Anglophones were being tried on questionable charges at the Yaounde military tribunal'. Nevertheless, he urged them to bury their leadership squabbles and forge ahead to achieve their goals. ${ }^{18} \mathrm{~A}$ few weeks later a new clash between the SDF and the SCNC occurred when the SDF decided to participate in the 20 May demonstrations - to commemorate the creation of the unitary state - while

16 See Scncforum, 26 May 2000, 'Can the SDF Solve the Anglophone Problem?' by N.N. Susungi.

17 The Herald, 11 June 2000.

18 Scnsforum, 19 May 2000, 'Fru Ndi Dissociates SDF from Southern Cameroons Independence'. 
the SCNC had called for a boycott. ${ }^{19}$ Recently, Fru Ndi has blamed President Biya for the radicalisation of the SCNC. Like Cardinal Tumi, he called on the president in 2001 to enter into negotiations with the SCNC leadership with a view to solving the Anglophone problem.

\section{Francophone views}

The Anglophone movements are inclined to present the Francophone population as a monolithic bloc. They claim that the Francophone population as a whole tends to be deaf or hostile to Anglophone grievances and calls for a return to a federal state. They even regularly allege that the Francophone population is actively involved in Anglophone marginalisation and exploitation and firmly supports the unitary state system. It cannot be denied that the majority of the Francophone population tends to deny the existence of an Anglophone problem and strongly disapproves of Anglophone agitations. Two factors appear to be largely responsible for this situation.

First, most Francophones have no idea what Anglophones are complaining about. They often stress that some Francophone regions are more marginalised than the Anglophone region and that there are close links between the ethnic groups on both sides of the Anglophone-Francophone divide that transcend any Anglophone-Francophone cleavage. Realising how ignorant most Francophones are of the history of the political union between the Southern Cameroons and $\mathrm{La}$ République du Cameroun and how little they know about federalism, Anglophone leaders decided to intensify their efforts to educate Francophones about the Anglophone problem and the federal option. Some Francophone papers, especially those controlled by the Bamileke, began to devote more attention to the Anglophone cause and to interview Anglophone leaders. ${ }^{20}$ While they mostly did not support the federalist option advocated by the Anglophone movements and parties, ${ }^{21}$ they called upon the government to start negotiating with the Anglophones. The presence of bilingual Anglophone journalists in the editorial or news teams of these Francophone papers helped to popularise Anglophone issues among their Francophone readership. At one point, the main Anglophone papers (Cameroon Post, The Herald and Post Watch) even ran French editions of their papers, which usually consisted of translations of

19 Scncforum, 18 May 2000, 'SDF Disagrees with SCNC over May 20 Boycott'.

20 See, for example, La Nouvelle Expression, 13-17 January 1994, pp. 1-13, devoted almost entirely to AAC spokesman, Dr Simon Munzu's 'special club de la presse' dubbed: 'çe que veulent les Anglophones'.

${ }^{21}$ See Cameroon Today, 11 September 1992, p. 11, which reviews some reports of Francophone papers on the Anglophone problem. 
English news stories. This has helped to bring the Anglophone problem to the Francophone consciousness.

Second, Francophones are being constantly exposed to their elite's usual defence of the unitary state and hostile reactions towards the Anglophone movement. In a recent article, for example, Professor Mono Ndjana (1996: 56) presents the establishment of the unitary state in 1972 as a manifestation of the Cameroonian people's rejection of the Anglophone-Francophone divide introduced by colonialism and their willingness to live together:

Dans sa marche vers l'unité, le Cameroun a plutôt choisi la voie de la centralisation en vue d'une grande union nationale, non par annexion d'une partie par un autre, mais par consensus comme expression d'un vouloir-vivre-ensemble. Les deux grands ensembles concernés étaient les deux états du Camerounais ex-anglais et du Cameroun ex-français, à savoir les deux parties d'une entité initiale que la parenthèse coloniale avait accidentalement divisée. Le réferendum du 20 mai 1972, par lequel les deux états occidental (Anglophone) et oriental (Francophone) décidaient de quitter le statut d'états féderés, pour effacer la dualité qu'implique la fédération et de devenir la 'République Unie du Cameroun', était donc ... une sorte de retour institutionnel aux sources, ou, si l'on veut, une récupération politique d'un paradis. Ce retour sur soi de la nation, à travers un consensus de $99.97 \%$, est une sorte de rejet symbolique de l'intermède colonial qui avait consacré une éphémère dichotomie sur la base d'éléments culturels importés.

He strongly condemns all those 'misguided' Anglophone leaders who continue to propagate an Anglophone-Francophone divide for the purpose of advancing their own political careers.

One should not, however, overlook the fact that there are even in Francophone Cameroon some political activists and intellectuals who tend to sympathise with the Anglophone cause, albeit without necessarily supporting the Anglophone call for federalism. Most of them belong to the opposition.

Initially, this minority group had a largely UPC background. In 1972, the UPC in exile was the only political organisation that dared to condemn Ahidjo's abolition of the federal state as 'a thinly veiled attempt at annexation' (Louka n.d.: 7). Henceforth it has never stopped drawing national attention to the frustrations and claims of the Anglophone community. Two UPC intellectuals have devoted some space to the Anglophone problem in their publications. In his book Introduction à la Politique Camerounaise, Abel Eyinga (1984: 271) denounces the Frenchification of Anglophone Cameroon and severely criticises the Francophone-dominated state's neo-colonialism and repression. He looks upon the creation of the unitary state as the final step in the 'dismantlement' of Anglophone Cameroon. A few years later, in 1989, Elenga Mbuyinga (pseudonym for Moukoko Priso), the present secretary-general of the UPC- 
MANIDEM, ${ }^{22}$ published a book entitled Tribalisme et Problème National en Afrique Noire in which he underscored the explosive nature of the Anglophone problem in Cameroon.

Following the emergence of Anglophone movements during political liberalisation, the number of Francophone supporters of the Anglophone struggle has been expanding outside UPC circles. In a contribution to the Cameroonian opposition paper Challenge Hebdo in 1991, ${ }^{23}$ Achille Mbembe accused the regime of repressing the Anglophone minority and warned it of the harmful consequences of its policy:

The failure to maintain national cohesion and to guarantee cultural pluralism without systematically resorting to repression has equally been manifested towards the question of the Anglophone minority....

The insistence of the regime to pursue a policy of political cohesion in line with the 1972 referendum on 'unification' has led to a growing malaise, notably among the youths and some intellectuals of the North West and South West Provinces. This malaise which the government did not want to admit ... has spread recently and has led to an increasing radicalisation of demands for autonomy. Hence the calls for a return to a federation or outright secession...

The situation is potentially explosive and is superimposed particularly on the South West in a larger dispute concerning the exploitation of oil.... The situation being created in Anglophone Cameroon is no different from what has happened in countries like Senegal (Casamance) and Sudan (South), where real civil or undeclared wars exist. Once again it brings to light the inability of the present regime to assume in an inventive manner the cultural pluralism inherent to the country.

Speaking to the journal Cameroon Life in July 1992, ${ }^{24}$ another well-known Francophone intellectual and political activist, Célestin Monga, stated that the Anglophone problem was the major challenge for Cameroon in the coming years. In the following year (1993), the famous Francophone writer, Mongo Beti (pseudonym for Alexander Biyidi Awala), a long-time political dissident and - since his return home from exile in France at the beginning of the 1990s a loyal member of the SDF, equally expressed his support for the Anglophone cause as well as for federalism. ${ }^{25}$

Some of those Francophone sympathisers, however, strongly disapprove of the way the Anglophone movements tend to present their cause. They maintain

22 UPC-MANIDEM stands for UPC Manifesto for the Institution of Democracy. It was launched by the UPC in exile in August 1974, three years after the execution of Ernest Quandie, the last historical leader of the party.

23 Challenge Hebdo, 10-17 July 1991.

${ }^{24}$ Cameroon Life, Vol. 2, No. 7, July 1992, p. 6.

${ }_{25}$ See The Herald, 1-8 September 1993, p. 5. 
that the tendency of Anglophone leaders to make the Francophone population as a whole responsible for the Anglophone predicament is likely to arouse misunderstandings and suspicion among Francophones, thus undermining their much-needed support. For example, Mr François Sengat-Kuoh, who used to be one of the regime's leading figures before joining the opposition, regularly cautioned Anglophone leaders about this tendency. In 1995, he admitted that Ahidjo had charged him with writing the 1972 constitution that abolished the federation. He nevertheless blamed the Anglophone leaders in particular for this event, alleging that they had lacked the courage to push their case and state their problems. He stressed that Francophones shared Anglophone frustrations with the highly centralised unitary state but that they tended to present their desire for a larger measure of autonomy less vigorously than Anglophones. He, too, considers the Anglophone problem as one of the most important problems facing the country and found the attitude of the government in this respect irresponsible. ${ }^{26}$ The eminent Francophone professor of public law, Maurice Kamto, agrees with most of Sengat-Kuoh's arguments. He insists that the Anglophone problem should be discussed frankly and in a spirit of patriotism and urges Francophones to desist from looking at federalism as a first step to secession..$^{27}$

Some Francophone scholars have started to carry out research on the Anglophone problem. Political scientists like Sindjoun (1995) and Nkoum-Me-Ntseny (1996a and b, 1999) have studied the current Anglophone struggle in some detail but without giving any indication of how the problem could be solved. Legal scholars like Olinga (1994) and Donfack (1998) appear to believe that the Anglophone problem can be solved by the introduction of a larger degree of decentralisation in the unitary state than the government is currently proposing. Olinga (1994) in particular argues that the creation of a truly decentralised state structure, possibly - but not necessarily - based on the existing ten provinces (see also Donfack 1998), would kill two birds with one stone. First, decentralisation offers a neat formula to fulfil the widespread wish in both Anglophone and Francophone Cameroon for a large measure of autonomy and to avoid the present dramatisation of the Anglophone-Francophone divide. Second, decentralisation would bring about a significant and necessary modernisation of the country's administration, providing the state with an adequate tool to experiment with new forms to manage the geographical, human and sociopolitical space. Olinga concludes that if one abstracts the Anglophone problem from its historical context, it is merely a problem of the Cameroonian state and it should take more seriously the potential benefits of a decentralised state

26 See Galaxie, 11 September 1995, p. 6 and Le Messager, 9 June 1992, p. 11.

27 See Le Messager, 24 June 1993, p. 2. 
structure. An anonymous Francophone scholar appears to have arrived at a similar conclusion:

The Anglophone problem appears to be foremost a problem of the existing institutions in the Cameroonian state rather than a problem of a national minority. Besides the Anglophones, there are also the Northerners and Westerners whose relations with the central power are equally tense, but not of a linguistic nature. ${ }^{28}$

Olinga's proposed solution to the Anglophone problem and his conception of the future form of state appear to be widely supported by Francophone political activists and intellectuals. There is, nevertheless, a tiny Francophone minority that favours a return to the federal state.

Compared to Anglophone Cameroon, the idea of a federal state has fewer historical roots in Francophone Cameroon. Nevertheless, it was not totally absent in the period preceding independence and reunification. In 1956 and 1957 before Ahidjo's accession to power, the Fulbe elite in Northern Cameroon brought strong pressure to bear upon the French to institute a federal system in Francophone Cameroon, similar to the one in Nigeria. They felt that France had promoted the development of the south to the detriment of the north and, as a result, they advocated the creation of a federal state after independence to forestall southern domination over the north. After the accession to power of their 'brother' Ahmadou Ahidjo in 1958, who replaced the Southerner AndréMarie Mbida as prime minister (Bayart 1979: 46-52), the Fulbe elite withdrew their federalist demands. Ironically, dismissed from power, Mbida immediately requested the United Nations and France create a Southern State and institute a federation (Louka n.d.: 50-51; Fogui 1990: 81-83). His request was rejected. Influenced by France and steeped in French Jacobine political culture, Ahidjo and the vast majority of the Francophone elite advocated a strong unitary state for an independent and reunified Cameroon. They were only prepared to accept a federation between Anglophone and Francophone Cameroon as a temporary arrangement (see Chapter 2).

The issue of federalism reappeared in Francophone Cameroon in the wake of political liberalisation and the Anglophone call for federalism. While most Francophone parties began to propagate a more or less decentralised unitary state, a few, some of them belonging to the (erstwhile) alliance of the extraparliamentary opposition, the Front of Allies for Change (FAC), supported the creation of a federation.

The FAC, comprising 16 opposition parties, included the SDF, by far the most important member and a supporter of a four-state federation. In 1995, the

28 L.P., 'Les Minorités Nationales', Le Courrier des ACP, No. 140, July-August 1993, p. 81 . 
FAC decided to join forces with the SCNC in order to exert additional pressure on the Biya regime to redress the Anglophone problem. ${ }^{29} \mathrm{FAC}$ members agreed upon three major points: (i) the establishment of a democratic state; (ii) the creation of a national, representative forum to debate the future form of state; and (iii) the approval of any new institutions by the people through a referendum (Louka n.d.: 39). They clearly differed on the future form of state.

Some FAC members, like the Union des Forces Démocratiques $d u$ Cameroun (UFDC) of Hameni Bieleu and the Mouvement pour la Démocratie Populaire (MDP) of Samuel Eboua opted for a large measure of decentralisation within the unitary state. ${ }^{30}$ Although these parties were prepared to support the Anglophone cause for strategic reasons (to bring down the regime and win votes among the Anglophones), they, like most other Francophones, actually denyed the existence of an Anglophone problem as such. In an interview with The Herald in June 1993, Hameni Bieleu declared:

The 'Anglophone problem' is not just a problem of the Anglophones. It is a problem of all Cameroonians. Look at the Eastern Province. If we have to consider the plight of the inhabitants of the Eastern Province in terms of infrastructural development, there is nothing to write home about in the East. Yet their forest and other resources are being exploited at a devastating rate. We must not divide Cameroon between Anglophones and Francophones. ${ }^{31}$

The position of the UPC-MANIDEM is somewhat more complicated. For this party, it is not the form of state that matters at this stage but the distribution of power within society. While the UPC-MANIDEM dismisses an internal federation, it proposes a progressive pan-Africanist federalism, which would unite Cameroon with Gabon, Congo, Equatorial Guinea, the Central African Republic and Chad. The party still claims to support the Anglophone struggle but is strongly opposed to Anglophone secession. This is understandable. Having fought for many years for a genuine reunification of Francophone and Anglophone territories, the UPC-MANIDEM rejects any partition of Cameroon (Louka n.d.).

It is necessary to emphasise that the position of the UPC-MANIDEM deviates from other factions in the UPC that are allied in one form or another to the ruling CPDM. One of these factions is led by Secretary-General Augustin Kodock, who was appointed minister of planning and regional development by Biya in 1992. This UPC faction is strongly opposed to a federation as demanded by the Anglophones. In 1993, Kodock declared:

29 See The Herald, 6-8 February 1995, p. 3 and 17-19 August 1995, pp. 1-2.

$30 \quad$ See Le Messager, 5 December 1994, p. 5.

31 The Herald, 9-16 June 1993, p. 6. 
A federation is a sure recipe for bringing in the Nigerian army. Linguistic fractioning brought about by colonisation cannot determine the future course of our country. The return of Anglophone Cameroon and the unification are the greatest achievements of Cameroon since independence. ${ }^{32}$

Another faction of the UPC led by Professor Hogbe Nlend (secretarygeneral) claims, like the UPC-MANIDEM, to sympathise with the Anglophone struggle. After running for the presidency in 1997, Hogbe Nlend was co-opted into the Biya government as minister of scientific research and had the courage in this function to challenge the continuing refusal of the government to enter into negotiations with Anglophone leaders. ${ }^{33}$ In an interview with the paper Le Messager in June 2000, he stated that the government had continued to pursue a policy of 'accelerated Frenchification and assimilation' of Anglophones rather than to seek viable solutions to the Anglophone problem. The solution, he said, was to provide Anglophone Cameroon with a special status. This would guarantee it the legitimate right to preserve its own cultural identity and its socio-political aspirations. ${ }^{34}$

A few FAC members appear to support a federation. One of them is the Mouvement Progressive (MP) of Jean-Jacques Ekindi. Unfortunately, the position of this party on the future form of state reflects the opportunist behaviour of its leader..$^{35}$ On 4 February 1992, Ekindi declared his support for a federal state. He appealed to President Biya to address the Anglophone problem immediately rather than to pretend that it did not exist. Dismissing the fears within government circles that federalism might be a first step towards separation, he said that none of the Anglophones parties had yet opted for secession. ${ }^{36}$ Curiously, only a few months later in April 1992, he rejected federalism as a future form of state, saying that a federal system was more costly than a unitary one. ${ }^{37}$ True to his contradictory spirit, three years later in 1995, he attacked the

32 The Herald, 9-16 June 1993, p. 6.

33 Professor Hogbe Nlend had already previously condemned the refusal of the regime to negotiate with the Anglophones. See, for example, Dikalo, 21-28 December 1995, p. 4.

34 See SCNC forum, 7 June 2000.

35 Ekindi used to be CPDM Wouri section president. In this capacity, he organised well-attended CPDM rallies in Douala after the launching of the SDF in May 1990, condemning multipartyism as being 'precipitate' and 'an imported model'. Following the introduction of multipartyism in December 1990, he started opposing 'the Kaiser of Mvomeka' (Paul Biya) and his 'dubious regime'. Eventually, he formed his own party. See Cameroon Post, 30 April-6 May 1992, p. 2.

36 Cameroon Post, 19-26 February 1992, p. 3.

37 Cameroon Post, 30 April-6 May 1992, p. 2. 
SCNC's adoption of the 'zero option' (an independent Southern Cameroons state), calling it a declaration of war. He then declared that he still looked upon federalism as the best form of government for Cameroon but he warned that the most suitable type of federation should be an issue of national debate. He stressed that he was willing to contribute to the solution of the Anglophone problem, adding that his party stood for a ten-state federation..$^{38}$

Another FAC member that advocates federation is Dr Adamou Ndam Njoya's Union Démocratique du Cameroun (UDC). The UDC has always insisted on government dialogue with the Anglophones and champions, like the MP of Jean-Jacques Ekindi, a ten-state federation. ${ }^{39}$ In July 1997, Dr Njoya declared that a federal constitution would be the only antidote to the economic and socio-political cancer that has penetrated so deeply into the fabric of Cameroonian society. ${ }^{40}$

Interestingly, some small Francophone parties aligned to the regime in power appear to favour federalism as well. The Parti de l'Alliance Libérale (PAL) under Célestin Bedzigui proposes a ten-state federation. In an interview with Le Messager in 1992, Bedzigui remarked:

Germany and the United States are no less united than France just because they have a federal system of government. We should put an end to the centralist Gaullist spirit inherited from France and then create efficient state structures. The national territory could be divided into ten states that are culturally homogeneous, demographically consistent and economically viable. ${ }^{41}$

Two other Francophone parties aligned to the regime champion a four-state federation, namely the Congrès Panafricain du Cameroun (CPC) led by Dr Djoumbi Sango and the Parti de Solidarité du Peuple (PSP) led by Woungly Massaga, the former secretary-general of the UPC in exile. While both leaders propose to group the two Anglophone provinces (South West and North West Provinces) and the two neighbouring Francophone provinces (the Littoral and West Provinces) into one state, Woungly Massaga still leaves room for a separate Anglophone state (Menthong 1998: 21-22; Donfack 1998: 44).

Finally, some Francophone political entrepreneurs have called from time to time for the creation of an ethnically-based federation, usually without mentioning the number of states. In 1991, for example, Enoh Meyomesse, editor-in-chief of the journal Le Courrier, proposed a Beti state comprising the

${ }_{38}$ The Herald, 26-29 October 1995, p. 2.

39 The Herald, 16-18 May 1994, p. 3 and 4-7 August 1995, p. 2. See also Donfack 1998: 39.

40 Cameroon Post, 22 July 1997, p. 4.

41 This part of his interview with Le Messager can be found in Cameroon Today, 11 September 1992, p. 11. 
Beti Central, South and Eastern Provinces. Others have called for a Bamileke and a Bassa state. Again, others have called for an ethnically-based state that even transcends Cameroonian borders. Professor Joseph Owona, one of the regime's strong men, once called for a Fang state comprising the Fang population in Cameroon, Gabon, Equatorial Guinea and Congo. The Mouvement de Renaissance Pahwin (MOREPAH) strives for a Pahwin state comprising the Pahwin and Pahwin-related groups in Cameroon, Gabon, Equatorial Guinea and Congo (Donfack 1998; Menthong 1998).

\section{Conclusion}

The tendency of the Anglophone movements to present Anglophones as supporters and Francophones as opponents of the Anglophone struggle is simplistic and even dangerous. Clearly, such a presentation tends to be harmful to the planning of these movements' viable strategies for the achievement of their objectives and to undermine any Francophone sympathy and support.

It cannot be denied, however, that there are significant differences between the Anglophone and Francophone responses to the Anglophone struggle. We have provided in this chapter some evidence that the majority of the Anglophones tend to support the claims of the Anglophone movements, while the majority of the Francophones continue to deny the existence of an Anglophone problem. Obviously, this tends to reinforce mutual distrust, suspicion and stereotypes.

On the other hand, Anglophones appear to be more divided than Francophones on the future form of state. Although the majority of Anglophones agree in principle upon a federation as proposed by the Anglophone movements, they clearly differ on the number of states. The situation has become even more complicated by the fact that the Anglophone movements have increasingly opted for secession. In sharp contrast to the Anglophones, most Francophones simply dismiss a federation and favour a more or less decentralised state. Moreover, the tiny Francophone minority that sympathises with the Anglophone struggle and champions the return to a federal state strongly rejects the current Anglophone separatist tendencies. 


\section{References}

ABBINK, J. (1995), 'Breaking and making the state: the dynamics of ethnic democracy in Ethiopia', Journal of Contemporary African Studies 13, 2: 149-163.

ABBINK, J. (1997), 'Ethnicity and Constitutionalism in Contemporary Africa', Journal of African Law 41: 159-174.

AKashambatwa (2001), Barotseland: Bastion of Resistance: What we Mean by SelDetermination. Paper presented at regional workshop on Interrogating the New Political Culture in Southern Africa, Harare Sheraton Hotel, 13-15 June 2001.

AKo, E.O. (2001), 'Nationalism in Recent Cameroon Anglophone Literature', Epasa Moto 1, 4: 3-28.

All Anglophone Conference (1993), The Buea Declaration, Limbe: Nooremac Press.

AmaAzeE, V.B. (1990), 'The "Igbo Scare" in the British Cameroons, c. 1945-61', Journal of African History 31: 281-293.

AmaAzEE, V.B. (1994), 'The Role of the French Cameroonians in the Unification of Cameroon, 1916-1961', Transafrican Journal of History 23: 195-234.

Ambanasom, S.A. (1996), 'Pedagogy of the Deprived: A Study of the Plays of Victor Epie Ngome, Bole Butake and Bate Besong', Epasa Moto 1, 3: 218-227.

ANDERson, B. (1991), Imagined Communities: Reflections on the Origins and Spread of Nationalism, London: Verso.

ARDENER, E. (1962), Divorce and Fertility: An African Study, London: Oxford University Press.

ARDENER, E. (1967), 'The Nature of the Reunification of Cameroon', in A. Hazlewood (ed.), African Integration and Disintegration: Case Studies in Economic and Political Union, pp. 285-337, Oxford: Oxford University Press.

ARDENER, E. (1996), Kingdom on Mount Cameroon: Studies in the History of the Cameroon coast 1500-1970, Providence/Oxford: Berghahn Books, Cameroon Studies, Vol. 1 (edited by S. Ardener).

Ardenter, E., Ardener, S., AND WARMIngton, W.A. (1960), Plantation and Village in the Cameroons, London: Oxford University Press.

ARDENER, S.G. (1958), 'Banana Co-operatives in the Southern Cameroons', Conference Proceedings, pp. 10-25, Ibadan: Nigerian Institute of Social and Economic Research.

ARDENER, S.G. (1968), Eye-Witnesses to the Annexation of Cameroon 1883-1887, Buea: Ministry of Primary Education and West Cameroon Antiquities Commission.

Atanga, M.L. (1994), The Political Economy of West Cameroon: A Study in the Alienation of a Linguistic Minority, M.Sc. Thesis, Ahmadou Bello University, Zaria. 
AwaSOM, N.F. (1998), 'Colonial Background to the Development of Autonomist Tendencies in Anglophone Cameroon, 1946-1961', Journal of Third World Studies 15, 1: 168-183.

AwASOM, N.F. (2000), 'The Reunification Question in Cameroon History: Was the Bride an Enthusiastic or a Reluctant One?', Africa Today 47, 2: 91-119.

AwASOM, N.F. (2001), Cameroon's Constitutional Developments 1960-1984, Ph.D. Thesis, University of Ibadan.

AYAMBA, L. PRINCE (2001), The Rights of the People of the Southern Cameroons to Self-Determination, Brussels, July.

AZARYA, V. (1978), Aristocrats Facing Change: The Fulbe in Guinea, Nigeria and Cameroon, Chicago: University of Chicago Press.

BACH, D.C. (ed.) (1999), Regionalisation in Africa: Integration and Disintegration, Oxford: James Currey.

BASTA, L.R., AND IBRAHIM, J. (eds.) (1999), Federalism and Decentralization in Africa, Fribourg: Institut du Fédéralisme.

BAYART, J.-F. (1978), 'The Neutralisation of Anglophone Cameroon', in R. Joseph (ed.), Gaullist Africa: Cameroon Under Ahmadou Ahidjo, pp. 82-90, Enugu: Fourth Dimension Publishers.

BAYART, J.-F. (1979), L'Etat au Cameroun, Paris: Presses de la Fondation Nationale des Sciences Politiques.

BAYART, J.-F. (1989), L'Etat en Afrique: La politique du ventre, Paris: Fayard.

BECKFORD. G.L. (1972), Persistent Poverty: Underdevelopment in Plantation Economies of the Third World, New York/London: Oxford University Press.

BenJamin, J. (1972), Les Camerounais occidentaux: la minorité dans un état bicommunautaire, Montréal: Les Presses de l’Université de Montréal.

BERRILL, K.E. (1960), The Economy of the Southern Cameroons Under United Kingdom Trusteeship, Buea (mimeo).

Besong, BAte (1990), Beasts of No Nation, Limbe: Nooremac Press.

Besong, BAte (1991), Requiem for the Last Kaiser, Calabar: Centaur Publishers.

BESONG, BATE (1993), 'Literature in the Season of the Diaspora: Notes to the Anglophone Cameroonian Writer, in N. Lyonga, E. Breitinger and B. Butake (eds.), Anglophone Cameroon Writing, pp. 15-18, Bayreuth African Studies 30: Weka No.1.

BIYA, P. (1987), Communal Liberalism, London/Basingstoke: Macmillan.

Boh, H., AND Ofege, N. (1991), Prison Graduate: A True Story of Cameroon Calling, Calabar: Apcon Ltd.

BoYLE, P.M. (1996), 'Parents, Private Schools, and the Politics of an Emerging Civil Society in Cameroon', The Journal of Modern African Studies 34, 4: 609-622.

Boyle, P.M. (1999), Class Formation and Civil Society: The Politics of Education in Africa, Aldershot: Ashgate.

Bratton, M., AND WaLle, N. VAN DE (1997), Democratic Experiments in Africa, New York: Cambridge University Press.

Brown, D. (1980), 'Borderline Politics in Ghana: The National Liberation Movement of Western Togoland', The Journal of Modern African Studies 18, 4: 575-609.

Burnham, P. (1996), The Politics of Cultural Difference in Northern Cameroon, London: Edinburgh University Press. 
Butake, Bole (1990), And Palm-Wine Will Flow, Yaoundé: Ed. Sopecam.

BUTAKe, Bole (1999), Lake God and other plays, Yaoundé: Ed. Clé.

CAmeroon National Union (1968), The Political Philosophy of Ahmadou Ahidjo, Yaoundé: Paul Bory Publishers.

Chabal, P., AND Daloz, J.-P. (1999), Africa Works: Disorder as Political Instrument, Oxford: James Currey.

CHEM-LANGHËË, B. (1976), The Kamerun Plebiscites 1959-1961: perceptions and strategies, Ph.D. Thesis, University of British Columbia.

CHEM-LANGHËË, B. (1995), 'The Road to the Unitary State of Cameroon, 1959-1972', Paideuma 41: 17-25.

Chem-LAnghËË, B. (1997), 'Anglophone-Francophone Divide and Political Disintegration in Cameroon: a psychological perspective', in P.N. Nkwi and F.B. Nyamnjoh (eds.), Regional Balance and National Integration in Cameroon: Lessons Learned and the Uncertain Future, pp. 88-99, Yaoundé/Leiden: ICASSRT.

Chem-Langhë̈̈, B., AND NJEumA, M.Z. (1980), 'The Pan-Kamerun Movement, 19491961', in N. Kofele-Kale (ed.), An African Experiment in Nation Building: The Bilingual Cameroon Republic Since Reunification, pp. 25-64, Boulder, Colorado: Westview Press.

Chia, NGAM (1990), The Path to Social Justice, Bamenda (mimeo).

CHIABI, E. (1982), Background to Nationalism in Anglophone Cameroon, Ph.D. Thesis, University of California, Santa Barbara.

Chumbow, S.B. (1980), 'Language and language Policy in Cameroon', in N. KofeleKale (ed.), An African Experiment in Nation Building: The Bilingual Cameroon Republic Since Reunification, pp. 281-311, Boulder, Colorado: Westview Press.

COLlECTIF « Changer le Cameroun » (1992), Le Cameroun Éclaté?: Une anthologie commentée des revendications ethniques, Yaoundé: Editions C3.

COLLECTIF « Changer le Cameroun », and Fondation Friedrich-Ebert (1994), Ethnies et Développement National: Actes du Colloque de Yaoundé 1993, Yaoundé: Editions C3/Editions du CRAC.

COURADE, G. (1981/82), 'Marginalité volontaire ou imposée: Le cas des Bakweri (Kpe) du Mont Cameroun', Cahiers ORSTOM, sér.Sci.Hum. 18, 3: 357-388.

DARBON, D. (ed.) (1995), Ethnicité et nation en Afrique du Sud : Imageries identitaires et enjeux sociaux, Paris : Karthala.

DeLAnCEY, M.W. (1989), Cameroon: dependence and independence, Boulder/San Francisco: Westview Press.

DerricK, J. (1992), 'Cameroon: One Party, Many Parties and the State', Africa Insight 22, 3: 165-177.

DoHO, G. (1996), 'Théâtre Universitaire et Instances en Post-Colonie', Epasa Moto 1, $3: 240-249$.

DonfaCK, L. (1998), 'Le renouveau de la question fédérale au Cameroun', Penant 826 (January-April): 30-61.

DongMO, J.-L. (1981), Le dynamisme bamiléké, Yaoundé: CEPER (2 vols.).

EBoussi Boulaga, F. (1997a), La démocratie de transit au Cameroun, Paris/Montréal: L'Harmattan.

Eboussi Boulaga, F. (ed.) (1997b), Democracy in the Throes of Tribalism, Yaoundé: Fondation Friedrich-Ebert \& Gerddes Cameroun. 
Ebune, J.B. (1992), The Growth of Political Parties in Southern Cameroons 19161960, Yaoundé: CEPER.

ElAigWU, J.I., AND OlORUNSOLA, V.A. (1983), 'Federalism and Politics of Compromise', in D. Rothchild and V.A. Olorunsola (eds.), State versus Ethnic Claims: African policy dilemmas, pp. 281-303, Boulder, Colorado: Westview Press.

EnONCHONG, H.N.A. (1967), Cameroon Constitutional Law: federalism in a mixed common-law and civil-law system, Yaoundé: Centre d'Edition et de Production de Manuels et d'Auxiliaires de l'Enseignement.

EPALE, S.J. (1975), Plantations and Development in Western Cameroon, 1885-1975: A Study in Agrarian Capitalism, New York: Vantage Press.

Esman, M.J. (1994), Ethnic Politics, Ithaca/London: Cornell University Press.

EYINGA, A. (1984), Introduction à la politique camerounaise, Paris: L'Harmattan.

EYOH, D. (1998a), 'Conflicting Narratives of Anglophone Protest and the Politics of Identity in Cameroon', Journal of Contemporary African Studies 16, 2: 249-276.

EYOH, D. (1998b), 'Through the Prism of a Local Tragedy: Political Liberalisation, Regionalism and Elite Struggles for Power in Cameroon', Africa 68, 3: 338-359.

EzERA, K. (1964), Constitutional Developments in Nigeria: an analytical study of Nigeria's constitution-making developments and the historical and political factors that affected constitutional change, Cambridge: Cambridge University Press (second edition).

FARDON, R. (1996), “ " Destins croisés »: histoires des identités ethniques et nationales en Afrique de l'Ouest', Politique Africaine 61: 75-97.

FEDERATION OF Nigeria, Federal Information Service, Lagos, for Southern Cameroons Information Service (1961), Southern Cameroons Plebiscite, 1961, The Two Alternatives, Buea: Printed by Authority of United Nations Plebiscite Commission.

FISIY, C.F. (1992), Power and Privilege in the Administration of Law: Land Law Reforms and Social Differentiation in Cameroon, Leiden: African Studies Centre, Research Report no. 48.

FISIY, C.F. (1995), 'Chieftaincy in the Modern State: An Institution at the Crossroads of Democratic Change', Paideuma 41: 49-61.

Fogui, J.-P. (1990), L'Intégration politique au Cameroun: Une analyse centrepéripherie, Paris: Librairie Générale de Droit et de Jurisprudence.

FOMBAD, C.M. (2001), 'Cameroon's Troubled Democratic Transition and the Deconstruction of the Federalist Problematic', unpublished paper.

FONDATION FRIEDRICH-EBERT (1993), Séminaire sur le rôle des médias dans la démocratisation au Cameroun, Yaoundé.

Fonge, F.P. (1997), Modernization without Development in Africa: Patterns of Change and Continuity in Post-Independence Cameroonian Public Service, Trenton, NJ: Africa World Press, Inc.

Fonlon, B. (1964), 'Will we Make or Mar', Abbia 5 (March): 9-34.

Fonlon, B. (1966), The Task of Today, Victoria: Cameroon Printing and Publishing Co.

FonsAH, E.G, AND CHIDEBELU, A.S.N.D. (1995), Economics of Banana Production and Marketing in the Tropics: A Case Study of Cameroon, Montreux/London/Washington: Minerva Press. 
GABRIEL, J.M. (1999), 'Cameroon's Neopatrimonial Dilemma', Journal of Contemporary African Studies 17, 2: 173-196.

GAILlARD, PH. (1994), Ahmadou Ahidjo (1922-1989), Paris: Jalivres.

GARDINIER, D.E. (1963), Cameroon: United Nations challenge to French policy, Oxford: Oxford University Press.

Geschiere, P. (1993), 'Chiefs and Colonial Rule in Cameroon: Inventing Chieftaincy, French and British Style', Africa 63, 2: 151-175.

GesChIERE, P., AND GUGLER, J. (1998), 'The Urban-Rural Connection: Changing Issues of Belonging and Identification', Africa 68, 3: 309-319.

GESCHIERE, P., AND KONINGS, P. (eds.) (1993), Itinéraires d'accumulation au Cameroun, Paris: Karthala.

GESCHIERE, P., AND NYAMNJOH, F.B. (1998), 'Witchcraft as an issue in the "politics of belonging": democratization and urban migrants' involvement with the home village', African Studies Review 41, 3: 69-91.

GeSCHIERE, P., AND NYAMNJOH, F.B. (2000), 'Capitalism and Autochthony: The Seesaw of Mobility and Belonging', Public Culture 12, 2: 423-425.

GHAI, Y. (1998), 'Decentralization and the Accommodation of Ethnic Diversity', in C. Young (ed.), Ethnic Diversity and Public Policy: A Comparative Inquiry, pp. 31-71, Houndsmills, Basingstoke: Macmillan Press Ltd.

GoHeEn, M. (1996), Men Own the Fields; Women Own the Crops, Madison, WI: University of Wisconsin Press.

Gonidec, P.-F. (1969), La République Fédérale du Cameroun, Paris : Ed. BergerLevrault.

Gonidec, P.-F., AND BREton, J.M. (1976), La République Unie du Cameroun, Paris: Ed. Berger-Levrault.

Grosh, B., AND MAKANDALA, R.S. (eds.) (1994), State-Owned Enterprises in Africa, Boulder/London: Lynne Rienner Publishers.

GwaN, E.A. (1975), Types, Processes and Policy Implications of Various Migrations in West Cameroon, Ph.D. Thesis, University of California.

GwELleM, J.F. (1996), Fru Ndi and the SDF Revolution, Bamenda: Unique Printers.

HENRY, A., TCHENK, G.H., AND GuILLERME-Dieumegard, P. (1991), Tontines et banques au Cameroun, Paris: Karthala.

Hugon, PH. (1968), Analyse du sous-développement en Afrique noire: L'exemple de l'économie du Cameroun, Paris: Presses Universitaires de France.

JEMBERE, A. (1999), 'Ethiopia : The Major Institutional Arrangements of Federation and Decentralization', in L.R. Basta and J. Ibrahim (eds.), Federalism and Decentralization in Africa, pp. 167-193, Fribourg: Institut du Fédéralisme.

JoHNSON, W.R. (1970), The Cameroon Federation: political integration in a fragmentary society, Princeton: Princeton University Press.

JOSEPH, R.A. (1977), Radical Nationalism in Cameroun: social origins of the U.P.C. rebellion, Oxford: Oxford University Press.

JoSEPH, R.A. (ed.) (1978), Gaullist Africa: Cameroon under Ahmadou Ahidjo, Enugu: Fourth Dimension Publishers.

JUA, N. (1991), 'Cameroon: Jump-starting an Economic Crisis', Africa Insight 21, 1: $162-170$. 
JuA, N. (1993), 'State, Oil and Accumulation', in P. Geschiere and P. Konings (eds.), Itinéraires d'accumulation au Cameroun, pp. 131-159, Paris: Karthala.

JuA, N. (1997), 'Spatial Politics and Political Stability in Cameroon', Keynote Address presented at a workshop on 'Cameroon: Bibliography of a Nation' held at Amherst College, USA, November 20-23, 1997.

JuA, N. (2001), 'Struggle for Definition and Resolution: The Anglophone Problem in Cameroon', unpublished paper.

Kale, P.M. (1967), Political Evolution in the Cameroons, Buea: Government Printer.

KLEIS, G.W. (1980), 'Confrontation and Incorporation: Igbo Ethnicity in Cameroon', African Studies Review 23, 3: 89-100.

Kofele-KaLe, N. (1980), 'Reconciling the Dual Heritage: Reflections on the "Kamerun Idea", in N. Kofele-Kale (ed.), An African Experiment in Nation Building: The Bilingual Cameroon Republic Since Reunification, pp. 3-23, Boulder, Colorado: Westview Press.

Kofele-Kale, N. (1981), Tribesmen and Patriots: political culture in a poly-ethnic African state, Washington, DC: University Press of America.

Kofele-Kale, N. (1986), 'Ethnicity, Regionalism, and Political Power: a post-mortem of Ahidjo's Cameroon', in M.G. Schatzberg and I.W. Zartman (eds.), The Political Economy of Cameroon, pp. 53-82, New York: Praeger Publishers.

Kofele-Kale, N. (1987), 'Class, Status, and Power in Postreunification Cameroon: The Rise of an Anglophone Bourgeoisie, 1961-1980', in I.L. Markovitz (ed.), Studies in Power and Class in Africa, pp. 135-169, New York/Oxford: Oxford University Press.

Konings, P. (1993a), Labour Resistance in Cameroon, London: James Currey.

Konings, P. (1993b), 'Contract Farming and Capital Accumulation in Cameroon: The Case of the CDC Smallholder Schemes', in P. Geschiere and P. Konings (eds.), Itinéraires d'accumulation au Cameroun, pp. 217-239, Paris: Karthala.

Konings, P. (1995a), Gender and Class in the Tea Estates of Cameroon, Ashgate: Avebury, African Studies Research Series no.5.

Konings, P. (1995b), 'Plantation Labour and Economic Crisis in Cameroon', Development and Change 26, 3: 525-549.

Konings, P. (1996a), 'The Post-Colonial State and Economic and Political Reforms in Cameroon', in A.E. Fernández Jilberto and A. Mommen (eds.), Liberalization in the Developing World: Institutional and economic changes in Latin America, Africa and Asia, pp. 244-265, London/New York: Routledge.

KonINGS, P. (1996b), 'Privatisation of Agro-Industrial Parastatals and Anglophone Opposition in Cameroon', Journal of Commonwealth \& Comparative Politics 34, 3 : 199-217.

Konings, P. (1996c), 'Le « problème anglophone » au Cameroun dans les années 1990’, Politique africaine 62 : 25-34.

Konings, P. (1997), 'Agro-Industry and Regionalism in the South West Province of Cameroon during the National Economic and Political Crisis', in P.N. Nkwi and F.B. Nyamnjoh (eds.), Regional Balance and National Integration in Cameroon: Lessons Learned and the Uncertain Future, pp. 289-305, Yaoundé/Leiden: ICASSRT. 
Konings, P. (1998), Unilever Estates in Crisis and the Power of Organizations in Cameroon, Hamburg: LIT Verlag.

KoningS, P. (1999a), 'The Anglophone Struggle for Federalism in Cameroon', in L.R. Basta and J. Ibrahim (eds.), Federalism and Decentralisation in Africa, pp. 289325, Fribourg: Institut du Fédéralisme.

Konings, P. (1999b), 'The "Anglophone Problem" and Chieftaincy in Anglophone Cameroon', in E.A.B. van Rouveroy van Nieuwaal and R. van Dijk (eds.), African Chieftaincy in a New Socio-Political Landscape, pp. 181-206, Hamburg: LIT Verlag.

KoningS, P. (2001a), 'National Populism and Social Democracy in Africa: Feasible Alternatives to the Current Neoliberal Hegemonic Project?', Working Paper, University of Amsterdam: Department of International Relations.

KonINGS, P. (2001b), 'Mobility and Exclusion: Conflicts between Autochthons and Allochthons during Political Liberalization in Cameroon', in M. de Bruijn, R. van Dijk and D. Foeken (eds.), Mobile Africa: Changing patterns of movement in Africa and beyond, pp. 169-194, Leiden/Boston/Köln: Brill

KoningS, P. (2002), 'University Students' Revolt, Ethnic Militia, and Violence during Political Liberalization in Cameroon', African Studies Review 45, 2: 179-204.

KonINGS, P. (2003), 'Anglophone University Students and Anglophone Nationalist Struggles in Cameroon', Leiden: ASC.

KoningS, P., AND NYAMnJoH, F.B. (1997), 'The Anglophone Problem in Cameroon', The Journal of Modern African Studies 35, 2: 207-229.

KonINGS, P., AND NYAMNJOH, F.B. (2000), 'Construction and Deconstruction: Anglophones or Autochtones?', The African Anthropologist 7, 1: 5-32.

Konings, P., AND NyAmnJoH, F.B. (2002), 'President Biya and the Anglophone Problem', in J. Takougang and J.M. Mbaku (eds.), The Leadership Challenge in Africa: Cameroon under Paul Biya, (forthcoming).

LAfon, I. Shey (1990/91), Divided We Stand, Let My People Go, Kumbo (mimeo).

LE VINE, V.T. (1964), The Cameroons: from mandate to independence, Berkeley/Los Angeles: University of California Press.

LE VINE, V.T. (1971), The Cameroon Federal Republic, Ithaca/London: Cornell University Press.

LE VINE, V.T. (1976), 'Political Integration and the United Republic of Cameroon', in D.R. Smock and K. Bentsi-Entchill (eds.), The Search for National Integration in Africa, pp. 270-284, New York: The Free Press.

Lisinge, A.D. (not dated), The Philosophy behind the University Crisis, (no publisher mentioned).

LOGO, P.B. (1999), 'Changement politique et dynamiques d'instrumentalisation de «l'ethnicité kirdi » : l'ingénierie ethnopolitique', in L. Sindjoun (ed.), La Révolution passive au Cameroun : État, société et changement, pp. 230-268, Dakar : CODESRIA.

LoukA, B. (not dated), Crisis of the State in Kamerun: The Stakes of Federalism, (no publisher mentioned).

LyONGA, N. (ed.) (1989), Socrates in Cameroon: The Life and Works of Bernard Nsokika Fonlon, Yaoundé/Leeds: Tortoise Books. 
Lyonga, N., Breitinger, E., AND Butake, B. (eds.) (1993), Anglophone Cameroon Writing, Bayreuth African Studies 30: Weka No.1.

Mama, T. (ed.) (1996), Crise Economique et Politique de Déréglementation au Cameroun, Paris: L'Harmattan.

MBAKU, J.M. (1996), 'Effective Constitutional Discourse as an Important First Step of Democratization in Africa', Journal of Asian and African Studies 31, 1-2: 39-51.

MBEmBe, A. (1993), 'Crise de légitimité, restauration autoritaire et déliquenscence de l'état', in P. Geschiere and P. Konings (eds.), Itinéraires d'accumulation au Cameroun, pp. 345-374, Paris : Karthala.

MbemBe, A. (1996), La Naissance du Maquis dans le Sud-Cameroun, 1920-1960, Paris: Karthala.

Mbile, N.N. (2000), Cameroon Political Story: Memories of an Authentic Eye Witness, Limbe: Presbyterian Printing Press.

MBU, A.N.T. (1993), Civil Disobedience in Cameroon, Douala: Imprimerie Georges Freres.

Mbuagbaw, T.E., Brain, R., AND Palmer, R. (1987), A History of the Cameroon, Harlow: Longman.

Mbuyinga, E. (1989), Tribalisme et Problème National en Afrique Noire, Paris: L'Harmattan.

McGarry, J., AND O'Leary, B. (eds.) (1993), The Politics of Ethnic Conflict Regulation, London/New York: Routledge.

MedArD, J.-F. (1977), 'L'état sous-dévéloppé au Cameroun', L'Année Africaine, Paris : Pedone.

MeHLer, A. (1993), Kamerun in derÄra Biya, Hamburg: Institut für Afrika-Kunde.

Melone, S., MinkoA She, A., And Sindjoun, L. (eds.) (1996), La Réforme Constitutionelle du 18 Janvier 1996 au Cameroun: Aspects Juridiques et Politiques, Yaoundé: Foundation Friedrich Ebert/GRAP.

MENTHONG, H.-L. (1998), 'La question locale dans le débat constitutionnel au Cameroun: chassé-croisé entre unité et pluralisme', Africa Development 23, 1: 5-40.

Messmer, P. (1998), Les Blancs s'en Vont : Récits de décolonisation, Paris : Albin Michel.

MKANDAWIRE, T. (1994), 'The Political Economy of Privatization in Africa', in G.A. Cornia and G.K. Helleiner (eds.), From Adjustment to Development in Africa: Conflict, Controversy, Convergency, Consensus?, pp. 192-213, New York: St. Martin's Press.

MoluA, H.N. (1985), The Bakweri Land Problem 1884-1961: A Case Study, M.A. Thesis, University of Ibadan.

MongA, C. (1992), 'La recomposition du marché politique au Cameroun (1991-1992)', Forum Démocratique (Bulletin de Gerddes-Cameroun) no.1.

MongA, Y. (2000), ' « Au vilage ! » Space, Culture, and Politics in Cameroon', Cahiers d'Études africaines 160, XL-4 : 723-749.

Mongo Beti (1993), La France contre l'Afrique : Retour au Cameroun, Paris : Éditions La Découverte/Essais.

Monono, C. Ewumbue (1991), The Torch and the Throne: The Political Philosophy of Bernard Fonlon, Yaoundé: Editions SOPECAM.

Monono, C. Ewumbue (2000), 'Effective Anglophone Agents', scncforum, 1 May. 
Mouiche, I. (1996), 'Mutations Socio-Politiques et Replis Identitaires en Afrique: Le Cas du Cameroun', African Journal of Political Science 1, 2 : 176-201.

Mukong, A. (1985), Prisoner without a Crime, Limbe: Alfresco.

MuKong, A. (ed.) (1990), The Case for the Southern Cameroons, Uwani-Enugu: Chuka Printing Company Ltd.

Mveng, E. (ed.) (1990), Catholic Church in Cameroon: 100 Years of Evangelization, Rome: Presso Grafiche Dehoniane.

NDJANA, H.M. (1996), 'Le dépassement ethnique: esquisse d'une théorie de l'identité', Epasa Moto 1, 3: 51-65.

NDOngKo, W.A. (1975), Planning for Economic Development in a Federal State: The Case of Cameroon, 1960-1971, Munich: Weltforum Verlag.

NDONGKO, W.A. (1980), 'The Political Economy of Regional Economic Development in Cameroon', in N. Kofele-Kale (ed.), An African Experiment in Nation Building: The Bilingual Cameroon Republic Since Reunification, pp. 227-250, Boulder, Colorado: Westview Press.

NdZAna, V. Ombe (1987), Agriculture, Pétrole et Politique au Cameroun: Sortir de la crise?, Paris : L'Harmattan.

NgAYAP, P.F. (1983), Cameroun: qui gouverne?, Paris : L'Harmattan.

NGniman, Z. (1993), Cameroun: La Démocratie Emballée, Yaoundé: Editions CLE.

NGOH, V.J. (1990), Constitutional Developments in Southern Cameroons, 1946-1961: from trusteeship to independence, Yaoundé: CEPER.

NGOH, V.J. (1992), 'The Peaceful Revolution, 1972-1992: Twenty Years After', Cameroon Life, May, pp. 8-13.

NGOH, V.J. (1996), History of Cameroon Since 1800, Limbe: Presbook.

NGOH, V.J. (2001), Southern Cameroons, 1922-1961: A Constitutional History, Aldershot: Ashgate.

NGome, V.E. (1992), What God Has Put Asunder, Yaoundé: Pitcher Books Ltd.

NGOME, V.E. (1993), 'Anglophobia', Focus of Africa 4, 3: 27-29.

NGONGO, L. (1982), Histoire des Forces Religieuses au Cameroun, Paris : Karthala.

NGU, J.N. (1989), 'The Political Economy of Oil in Cameroon', in P. Geschiere and P. Konings (eds.), Proceedings/Contributions of the Conference on the Political Economy of Cameroon - Historical Perspectives, Leiden, June 1988, pp. 109-146, Leiden: African Studies Centre, Research Report no. 35, vol. I.

NgWAfOR, E.N. (1989), May Former Victoria Smile Again, London: Institute of Third World Art and Literature.

NGWANE, G. (1993), Bate Besong (or the Symbol of Anglophone Hope), Limbe: Nooremac Press.

NGWANE, G. (1994), The Anglophone File, Limbe: Presbook.

Ngwane, G. (1996), Settling Disputes in Africa: Traditional Bases for Conflict Resolution, Yaoundé: Buma Kor.

Niger-THOMAS, M. (2000), "Buying Futures": The upsurge of female entrepreneurship crossing the formal/informal divide in South West Cameroon, Ph.D. Thesis, University of Leiden.

NJeUmA, M.Z. (1995), 'Reunification and Political Opportunism in the Making of Cameroon's Independence', Paideuma 41: 27-37. 
NKOUM-ME-NTSENY, L.-M.M. (1996a), 'Dynamique de positionnement anglophone et libéralisation politique au Cameroun: de l'identité à l'identification', POLIS: Cameroonian Political Science Review 1: 68-100.

Nkoum-Me-NTSENY, L.-M.M. (1996b), 'Les « Anglophones » et le processus d'élaboration de la constitution du 18 janvier 1996', in S. Melone, A. Minkoa She, and L. Sindjoun (eds.), La Réforme Constitutionnelle du 18 Janvier 1996 au Cameroun: Aspects Juridiques et Politiques, pp. 200-227, Yaoundé: Fondation Friedrich Ebert/GRAP.

NKOUM-ME-NTSENY, L.-M.M. (1999), “ «Question anglophone », libéralisation politique et crise de l'état-nation: « les ennemis dans la maison? »', in L. Sindjoun (ed.), La Révolution Passive au Cameroun: Etat, Société et Changement pp.157229, Dakar: Editions Démocraties Africaines.

NKWI, P.N. (1985), 'Traditional female militancy in a modern context', in J.-C. Barbier (ed.), Femmes du Cameroun: Mères pacifiques, femmes rebelles, pp.181-191, Paris: Orstom/Karthala.

NKWI, P.N., AND NYAMNJOH, F.B. (eds.) (1997), Regional Balance and National Integration in Cameroon: Lessons Learned and the Uncertain Future, Yaoundé/Leiden: ICASSRT Monograph no.1.

NKWI, P.N., AND WARNIER, J.-P. (1982), Elements for a History of the Western Grassfields, Yaoundé: SOPECAM.

NsaHlaI, C. (1996), Look Up to the Mountain Top: Beyond Party Politics, Yaoundé: Imprimerie Adventiste.

NwEL, P. TITI (1995), 'The Churches and the Democratic Upheaval in Cameroon 1982-1993, in P. Gifford (ed.), The Christian Churches and the Democratisation of Africa, pp. 168-187, Leiden/New York/Köln: Brill.

NyAMNJOH, F.B. (1989), Broadcasting for Nation-Building in Cameroon: Development and Constraints, Ph.D. Thesis, CMCR, University of Leicester.

NyAMNJOH, F.B. (1990), 'How to "Kill" an Underdeveloped Press: Lessons from Cameroon', Gazette 46, 1: 57-75.

NyamnjoH, F.B. (1991), Mind Searching, Awka: Kucena Damian Nigeria Limited.

Nyamnjoh, F.B. (ed.) (1996a), The Cameroon G.C.E. Crisis: A Test of Anglophone Solidarity, Limbe: Nooremac Press.

NyamnJoH, F.B. (1996b), Mass Media and Democratisation in Cameroon, Yaoundé: Foundation Friedrich-Ebert.

NyAMnJOH, F.B. (1996c), 'Media and Multi-Party Politics in Transitional Cameroon', Nord-Süd Aktuell 10, 4: 738-752.

NyAMNJOH, F.B. (1996d), 'The English Language Media and the Exigency of Conviviality', in C.G. Mbock (ed.), Cameroun: Pluralisme Culturel et Convivialité, pp.101-117, Ivry: Editions Nouvelles du Sud.

NyamnJoH, F.B. (1996e), 'Protest Journalism as a Literary Genre: The Case of Anglophone Cameroon Journalism Today', Epasa Moto 1, 3: 350-357.

NyAmNJOH, F.B. (1999), 'Cameroon: A Country United by Ethnic Ambition and Difference', African Affairs 98, 390: 101-118.

NyAmnJOH, F.B., AND Rowlands, M. (1998), 'Elite Associations and the Politics of Belonging in Cameroon', Africa 68, 3: 320-337. 
NYANSAKO-NI-NKU (ed.) (1993), Cry Justice!: The Church in a Changing Cameroon, Limbe: Presbook Press.

OLINGA, A.D. (1994), 'La « question anglophone» dans le Cameroun d'aujourd'hui', Revue Jurique et Politique 3: 292-308.

OLINGA, A.D. (1998), 'La protection des minorités et des populations autochtones en droit public camerounais', African Journal of International and Comparative Law 10, 2: 271-291.

Olukoshi, A.O., AND AgBu, O. (1996), 'The Deepening Crisis of Nigerian Federalism and the Future of the Nation-State', in A.O. Olukoshi and L. Laakso (eds.), Challenges to the Nation-State in Africa, pp. 74-101, Uppsala: Nordiska Afrikainstitutet.

OluKoshi, A.O., AND LAAKSO, L. (eds.) (1996), Challenges to the Nation-State in Africa, Uppsala: Nordiska Afrikainstitutet.

PHILLIPSON, SIR SYDNEY (1959), Report on the Financial, Economic and Administrative Consequences to Southern Cameroons of Separation from the Federation of Nigeria, Buea: Prime Minister's Office, Southern Cameroons.

POKAM, S. (1987), La philosophie politique trahie: le monofacisme, Paris : Silex.

RothCHILD, D. (1997), Managing Ethnic Conflict in Africa: Pressures and Incentives for Cooperation, Washington, D.C.: Brookings Institution Press.

Rowlands, M. (1993), 'Accumulation and the Cultural Politics of Identity in the Grassfields', in P. Geschiere and P. Konings (eds.), Itinéraires d'accumulation au Cameroun, pp. 71-97, Paris: Karthala.

RuBIN, N. (1971), Cameroun: an African federation, London: Pall Mall Press.

RudiN, H.R. (1938), Germans in the Cameroons: A Case Study in Modern Imperialism, New Haven: Yale University Press.

SANDBRooK, R. (2000), Closing the Circle: Democratization and Development in Africa, Toronto: Between the Lines.

SCHILDER, K. (1994), Quest for self-esteem: State, Islam and Mundang ethnicity in northern Cameroon, Leiden: African Studies Centre Research Series no. 3.

SHANKLIN, E. (1990), 'Anlu Remembered: The Kom Women's Rebellion of 1958-61', Dialectical Anthropology 15: 159-181.

SiMO, J.A. Mope (1997), 'Land Disputes and the Impact on Disintegration in Contemporary Western Grassfields: Case Study of the Ndop Plain Chiefdoms', in P.N. Nkwi and F.B. Nyamnjoh (eds.), Regional Balance and National Integration in Cameroon: Lessons learned and the uncertain future, pp. 225-241, Leiden/Yaoundé: ASC/ICASSRT.

SINDJOUN, L. (1995), 'Mobilisation politique du pluralisme culturel et crise de l'étatnation au Cameroun', in I. Mane (ed.), Etat, démocratie, sociétés et culture en Afrique, pp. 87-115, Dakar: Editions Démocraties Africaines.

SoH, P.B. (1999), Dr. John Ngu Foncha: The Cameroonian Statesman (A Biography), Bamenda: Unique Printers.

STARK, F.M. (1976), 'Federalism in Cameroon: the shadow and the reality', Canadian Journal of African Studies 10, 3: 423-442.

SuBERU, R. (1999), 'Integration and Disintegration in the Nigerian Federation', in D.C. Bach (ed.), Regionalisation in Africa: Integration and Disintegration, pp. 91-101, Oxford: James Currey. 
Susungi, N.N. (1991), The Crisis of Unity and Democracy in Cameroon, (no publisher indicated).

TABAPSSI, F.T. (1999), Le modèle migratoire Bamiléké dans le Moungo (Cameroun) et sa crise actuelle: Perspective économique et culturelle, Ph.D. Thesis, University of Leiden.

TAKougang, J. (1993), 'The demise of Biya's New Deal in Cameroon, 1982-1992', Africa Insight 23, 2: 91-101.

TAKougAng, J. (1996), 'The « Union des populations du Cameroun » and its Southern Cameroons connection', Revue française d'histoire d'outre-mer 83, 340: 7-24.

Takougang, J., AND KrIEger, M. (1998), African State and Society in the 1990s: Cameroon's Political Crossroads, Boulder/Oxford: Westview Press.

TAKU, C.A. (1996), For Dame Lynda Chalker \& Other Anglophone Cameroonian Notes, Aba: Iduma Industries (Nigeria) Limited.

TANGRI, R. (1995), 'The Politics of Africa's Public and Private Enterprise', Journal of Commonwealth and Comparative Politics 33, 2: 169-184.

TANGri, R. (1999), The Politics of Patronage in Africa: Parastatals, Privatization and Private Enterprise, Oxford: James Currey.

Tatah Mentan, E. (1996), 'Constitutionalism, Press, and Factional Politics: Coverage of SAWA Minority Agitations in Cameroon', in S. Melone, A. Minkoa She, and L. Sindjoun (eds.), La Réforme Constitutionnelle du 18 Janvier 1996 au Cameroun: Aspects Juridiques et Politiques, pp. 182-198, Yaoundé: Fondation FriedrichEbert/GRAP.

Tedga, P.J.M. (1990), Enterprises publiques, état et crise au Cameroun, Paris: L'Harmattan.

Thomas-WoOlley, B., AND Keller, E.J. (1994), 'Majority Rule and Minority Rights: American Federalism and African Experience', The Journal of Modern African Studies 32, 3: 411-427.

TitA, J.C. (ed.) (1993), A Time of Hope: Anglophones on the Anglophone Problem, Limbe: Nooremac Press.

VERDZEKOV, P.B. (1969), The Relationship between Trade Unions and Political Parties in West Cameroon, Ph.D. Thesis, Pontifical University Gregoriana.

WACHE, F.K., 'The Plebiscite: Thirty Years After; The Choice between Fire and Deep Water', Cameroon Life 1, 8: 6-10.

WALKER, S. TJIP (1992), 'The Poverty of African Federalism: Lessons from the Federal Republic of Cameroon', unpublished paper, Indiana University: African Studies Program.

Walle, N. VAN DE (1993), 'The Politics of Nonreform in Cameroon', in: T.M. Callaghy and J. Ravenhill (eds.), Hemmed In: Responses to Africa's Economic Decline, pp. 357-397, New York: Columbia University Press.

Walle, N. VAN DE (1994), 'The Politics of Public Enterprise Reform in Cameroon', in B. Grosh and R.S. Makandala (eds.), State-Owned Enterprises in Africa, pp. 151174, Boulder/London: Lynne Rienner Publishers.

Walle, N. VAN DE (2001), African Economies and the Politics of Permanent Crisis, 1979-1999, Cambridge Cambridge University Press. 
WANG SONNE (1997), 'De la Dynamique de la Qualité d'Autochtone dans la Démocratisation au Cameroun: Cas de la Région de Douala', in D. Zognong and I. Mouiche (eds.), Démocratisation et Rivalités Ethniques au Cameroun, pp. 179-199, Yaoundé: CIREPE.

WARNIER, J.-P. (1993), L'esprit d'entreprise au Cameroun, Paris: Karthala.

Welch, C.E. (1966), Dream of Unity: Pan-Africanism and Political Unification in West Africa, Ithaca, N.Y.: Cornell University Press.

Wilmsen, E.N., AND MCAllister, P. (eds.), The Politics of Difference: Ethnic Premises in a World of Power, Chicago/London: The University of Chicago Press.

Wirba, Dinayen Fr. (1992), Sunday Politics, Calabar: Scale Printing Press.

Wirba, DinAYEn Fr. (1993), Sunday Report, Calabar: Scale Printing Press.

Woodward, P., AND Forsyth, M. (eds.) (1994), Conflict and Peace in the Horn of Africa: federalism and its alternatives, Aldershot: Dartmouth.

WunsCH, J.S., AND Olowu, D. (eds.) (1990), The Failure of the Centralized State: Institutions and Self-Governance in Africa, Boulder, Colorado: Westview Press.

Yenshu, E. (1998), 'The Discourse and Politics of Indigenous/Minority Peoples Rights in Some Metropolitan Areas of Cameroon', Journal of Applied Social Sciences 1, 1: 59-76.

Young, C. (ed.) (1998a), Ethnic Diversity and Public Policy: A Comparative Inquiry, Houndsmills, Basingstoke: Macmillan Press Ltd.

Young, C. (1998b), 'Ethnic Diversity and Public Policy: An Overview', in C. Young (ed.), Ethnic Diversity and Public Policy: A Comparative Inquiry, pp. 1-30, Houndsmills, Basingstoke: Macmillan Press Ltd.

ZoGNONG, D. (1997), 'La Question Bamiléké Pendant l'Ouverture Démocratique au Cameroun', in D. Zognong and I. Mouiche (eds.), Démocratisation et Rivalités Ethniques au Cameroun, pp. 123-155, Yaoundé: CIRIPE.

Zognong. D., AND Mouiche, I. (eds.) (1997), Démocratisation et Rivalités Ethniques au Cameroun, Yaoundé: CIRIPE. 



\section{Index}

A

AAC (All Anglophone Conference) . 84-86, 88-91, 94, 100, 106, 111, $127,135,147-148,153,166,172$, 198

Achu, Simon Achidi · 83, 91, 114-116, $119,147,166-167,169-171,178$

Africa $1-2,6,10,18-19,24,33,36$, $57,61,82,94,96,100,140,164$, $173,183,201,204$

Ahidjo, Ahmadou · 4-7, 10-13, 16, 3438, 40- 66, 68-69, 71-72, 74-75, 81, $85,94,96,110,143,154,156-157$, 173, 195

Akwanga, Ebenezer $\cdot 104$

allochthony $\cdot 131,146$

Ambazonia $\cdot 19,73,94$

Ambazonian Movement (AM) $\cdot 80$, 105, 199

Anglo-Bami · 13, 145, 146

Anglophone Advisory Committee $\cdot 90$

Anglophone Cameroon · 2, 5, 8-14, 16, 19-21, 43, 48, 54, 56, 68-69, 72, 77$80,82,84,90,95,99-100,108,136$, $140,142-144,148,154-155,157$, $159,163,166,174,176,180-182$, 184-185, 198, 203-204, 206

Anglophone Council · 90

Anglophone problem · 2, 9-11, 21, 22$23,68,80-81,85,88,94,96,99$, 108-109, 114-115, 120, 129, 131, 136, 139, 143, 146, 148, 152-159, 161, 193, 196, 198, 201-203, 205, 207

Anglophone Standing Committee $\cdot 85$ 88, 90, 94, 97, 100-102, 113

Anlu $\cdot 30$

Annan, Kofi · 96, 121, 203, 205 annexation $\cdot 35,73,80,91,95,98,154$, 195,201

Anyangwe, Carlson $\cdot 83,85,88,94$, $102,127,152$

armed rebellion $\cdot 27,104,110$

autochthonous $\cdot 15,17,82,93,117$, $121,137,145,198,202$

autochthony $\cdot 82,106,131-132,146$ autonomy $\cdot 2,4,9,11-12,16,18,20$ $21,25,34,38,44,49,51-52,56-58$, $64,67,73-76,82,85-86,91,94$, $113-114,137,142,146-147,155-$ 156, 194-197, 199, 206, 207

Azong Wara, Andrew · 170-172

B

Bakweri - 27-28, 38, 65, 131-132, 136, 174-176, 178-179, 181-182, 184$185,187-191$

Bakweri Land Committee (BLC) 175 , 187

Bamenda $\cdot 8,31,38-39,42,44-45,60$, $73,77,79-80,82,86,89-90,92,94-$ $97,100,105,108-109,112,114$, 116, 121-123, 127, 133-135, 141, 146-148, 165, 168-170, 172, 183, 186, 191, 197, 200

Bamenda Proclamation $\cdot 82,90,92,95$, 108

Bamileke · 6-7, 9, 12-13, 20, 26, 63, 79, $118,130-131,145-146,150-153$, 161,203

Bamoun 9

Basil, Emah $\cdot 151$

Bayang $\cdot 131-132$

Beti $\cdot 6-9,13,70,144-146,155,160$, 166, 203 
Biafra $\cdot 19,65$

bilingualism $\cdot 56,58,109,148,164$

Bisong, Bate $\cdot 70-71,164$

Biya, Paul · 6-8, 11, 13, 17, 21, 52, 64, 69- 75, 78, 80-82, 84-85, 90-91, 9598, 100-101, 103-104, 108-112, $114-117,119-122,126,133,136-$ $137,144,146-147,152,158-159$, 164, 167, 172-174, 178, 180, 183, 184-187, 189, 196-197, 201-202, 204

BLCC (Bakweri Land Claims Committee) $\cdot 184,187-191$

BPI (Buea Peace Initiative) · 88-89, 92, 95

Britain $\cdot 13,19,41,55,99,141,164$, 175,201

British administration $\cdot 14$ authorities $\cdot 15,26-27,37$ Cameroon $\cdot 22,24,34$

Buea $\cdot 21,42,80,83-86,88-90,92,95$, $100,105-106,112-113,116,118-$ 120, 127-128, 131, 133, 135-136, $147,149,165,167-170,183-185$, 187, 189-190

Buea Declaration · 84-85, 112

Butake, Bole $\cdot$ 142, 144, 195

C

CAM (Cameroon Anglophone Movement) $\cdot 80-81,84-85,88,92$, 95, 101-103, 166, 183

CANSA (Cameroon Anglophone Public Servants' Union) $\cdot 80$

CAPTAC (Confederation of Anglophone Parents-Teachers' Association of Cameroon) $\cdot 80-81$, $166,168-169$

Casamance $\cdot 19,155$

CBC (Cameroon Baptist Convention) · $144,147-148$

CDC (Cameroon Development corporation) $\cdot 70,118,121,162$, 173-191, 198

centralisation $\cdot 4,18,69,154,197,205$
Chief (see also Fon) · 33, 97, 118-120, $122,125,132,169,177,178,184-$ $185,187,189-190$

chieftaincy $\cdot 14,28,30,47,112$

civil war · 1, 4, 18, 27, 30, 32-33, 49, 64

CNU (Cameroon National Union) · 4, $7,47,62,73$

colonial

administration $\cdot 26,65,194$

borders $\cdot 2,10$

rule $\cdot 2,144$

colonialism · 33, 99, 147, 154

Commonwealth · 55, 94, 96-99, 105, 176,200

constitution federal · 40-41, 43-44, 48, 50, 52, $57,59,61,64,81,84,86-87,160$, 193, 195, 205

CPDM (Cameroon People's

Democratic Movement) · 7, 9, 20, 73, 77-78, 83, 91, 101, 106, 112114, 116-122, 132, 136-138, 145, 149, 158-159, 166, 169, 171-172, 178,201

CPNC (Cameroon People's National Congres) $\cdot 30,36-38,49$, 59-62

CRTV (Cameroon Radio and Television) $\cdot 105,111,122-129$, 133-134, 141, 172

CUC (Cameroon United Congress) . 61-62

D

de Gaulle, Charles · 195

decentralisation $\cdot 20,35,83,101,110$, $121,140,150,156,158,206-207$

decolonisation $\cdot 9,15,17$

democratisation $\cdot 18,98,115$

development

economic $\cdot 2,18,24,36,44,64,67$, $116,176,193,195$

political $\cdot 23-24,59$ regional $\cdot 24,149,158,182$

diaspora $\cdot 78,82,103,106,130,187$, 202-203 
Dinka, Gorji · 19, 72, 73, 80, 94, 199 diplomatic offensive $\cdot 76,94,99,198$ domination

Francophone $\cdot 11,68,75,85,108$, $142,148,151,196$

Nigerian $\cdot 25,27$

North West · 16, 60, 78, 86, 111 , $137,149,178,198$

Douala $\cdot 42-43,55,73,80,89,95,118$, $128,130,133,137,140,145-146$, 159,182

\section{$\boldsymbol{E}$}

East Cameroon $\cdot 46-48,53,55-57,59$ $60,62,66,141$

Ebong, Frederick Alobwede · 105-107, $113,115-116,135,138,151,177$, 199-200

education

Anglophone $\cdot 21,70,147,163,166-$ 167

national · 70, 163, 164-165, 167-172

Elad, Sam Ekontang · 83, 85, 88, 94, $102-103,121,127,133,135,149$, 199

elite

Anglophone - 2, 9-11, 15-16, 18, 20$21,48,50,68,73,80-81,84,111$, 115, 140, 195-196, 198, 202, 204, 206

Francophone $\cdot 2$, 9-12, 16-18, 20, $26,66,74,140,157,195,196$, 202, 204, 206

North West · 14, 16-17, 31, 113, $131,137,198$

South West · 13, 15-18, 20, 31, 68, 78, 111, 115-119, 137, 198-199, 206

Endeley, Emmanuel · 15, 26-33, 36-38, 49, 59-60

Endeley, Samuel · 113, 177-178, 184$185,187,190$

Eritrea $\cdot 17,19,200,204$

Ethiopia $\cdot 17-19,204$

ethnic

balance $\cdot 5-7$ cleansing $\cdot 17,117,130$

groups - 4-7, 12, 25, 28, 43, 60, 79, $82,118,137,153$

links $\cdot 11-12,85$

relations $\cdot 9,20$

ethno-regional

conflict $\cdot 96$

groups $\cdot 1,17,206$

protest $\cdot 2$

exploitation $\cdot 52,67,74,89,118,137$, $142,153,155,196$

\section{F}

Fako Division · 131-132

federal

government $\cdot 11,34,36,45-47,52$, $53,58,65,75,195,205$

inspector $\cdot 53-54,195$

state $\cdot 11,16,18,20-21,35,42,44-$ $45,49,54,58-59,61,63,76-77$, 79-80, 83, 85-86, 88-90, 93-94, 103, 107, 110, 113, 139, 142, 147-148, 153-154, 157, 159, 161, 198-199, 202, 204-206

system · 41, 48, 86, 148-149, 157, $159-160$

Federal Republic of Cameroon - 4, 44$45,52-53,55,58,62,71,90-91,95$ 96

federalism · 1-2, 16-20, 34-35, 46, 5051, 64, 66, 76, 79, 88, 92, 99, 101, 106-107, 110-111, 146, 150-151, 153-160, 197-198, 205-207

federation · $4,10,16-18,20,22-23,34-$ $37,41-42,44,48-54,56-64,66,74-$ $75,81,86,88,95,110,113,137$, $143,148-152,155-161,195,198$, 204-206

Fon (see also Chief) · 19, 28, 32, 72, 73, 80, 94, 96, 120, 142, 199

Foncha, John Ngu · 10, 12-13, 15-16, $27,29,31-38,40-44,46,48-50,52-$ 53, 55-58, 60, 62-63, 77-78, 91, 94, $96,100,104,121,141,164,187$, 204 
Fossung, Henry · 93, 103-104, 133, $135,149,151,187,199$

Foumban conference $\cdot 43,49,56-57$ constitutional talks $\cdot 16$

France $\cdot 4,13,41,55,99-100,128$, $141,152,155,157,160,180,183$, 195,198

Francophone Cameroon · 2, 4, 6, 9-13, $15,20,22,26,33,36,40,43,48-49$, $63,65,68,72,79,81,90,95,137$, $141,144,148,150,154,156-157$, 163, 194-195, 203-204, 206

French administration $\cdot 100$ authorities $\cdot 27,100$

FRSC (Federal Republic of Southern Cameroons) $\cdot 105,151$

Fulbe $\cdot 4,6-7,9,12-13,157$

FWCM (Free West Cameroon Movement) $\cdot 80,88,183,199$

G

GCE (General Certificate of Education) . $70,81,125,136,147,162-172$, 191, 198

GCE Board · 166-172, 191, 198

gendarmerie $\cdot 54$

German colonial rule $\cdot 14,25,109,184$

German Kamerun Protectorate · 10, 12, 22-23

Ghana $\cdot 17,27$

ghost town $\cdot 55,112,133,148$

Grand Sawa Movement (see also Sawa) $\cdot 13,199$

Grand West · 20, 119, 137

Grassfields · 2, 6, 9, 12-14, 16, 30-31, $66,117-118,130-131,142,197$

\section{$\boldsymbol{H}$}

Harare Declaration · 97-98

harmonisation $\cdot 56,68,163$

hegemonic alliance $\cdot 5-6,8,11,16,68$, $75,115,173$
House of Chiefs (see also Chief) $\cdot 28$, $43,47,66$

human rights $\cdot 6,42,97-98,133,146$ 147,152

I

identity

Anglophone $\cdot 2$, 9-10, 14, 16, 21, 50, $56,82,97,108,118,120,122$, $129,133,136-137,163,196$

cultural $\cdot 66,159,206$

ethnic $\cdot 11$

North West $\cdot 13$

South West · 15-16, 117

Igbo $\cdot 24-25,30,38,49,64,194$

IMF (International Monetary Fund) $\cdot 8$, $99,179,186,188-189$

independence $\cdot 1-2,4,6,12,18-19,25$ $26,29,32-37,44-45,49,57,72,76-$ 77, 88-90, 92-95, 98-99, 102-107, $128,135,138,148,151-152,157$, 159, 173, 176-177, 194, 198-201, 205

independent state $\cdot 19,33,37,88-89$, 200-201, 203

Inoni, Ephraim · 113, 115, 185, 190

$\boldsymbol{J}$

journalist

Anglophone $\cdot 81$

Jua, Augustine Ngom · 5, 7, 29-30, 34, $60-63,68-69,99,121,130,173,182$ judiciary $\cdot 86-87,98$

\section{$\boldsymbol{K}$}

Kale, P.M. · 11, 16, 25, 31, 32-33, 56, $59,65,67-68,184,188,196$

Kenya $\cdot 17,98,188$

Kirdi $\cdot 7,9$

KNC (Kamerun National Congress) · $15,27,29-30$ 
KNDP (Kamerun National Democratic Party) · 12-13, 15-16, 29-32, 34, 3638, 41-43, 49-50, 55, 57-64, 194

KPP (Kamerun People's Party) · 30

Kumba · 39, 55, 60, 62, 102, 113-114, $118,120,123,185$

$\mathrm{Kumbo} \cdot 200$

KUNC (Kamerun United National Congress $) \cdot 26$

KUP (Kamerun United Party) · 19, 3233

\section{$\boldsymbol{L}$}

labour migration $\cdot 14$

language

English $\cdot 69,124$

French $\cdot 56,109$

LDA (Liberal Democratic Alliance) $78,83,133,149$

liberalisation political · 1, 2, 8, 11, 13, 17, 21, 76$78,80,99,106-107,144,146$, $155,157,193,197,203$

Limbe (see also Victoria) · 55, 67, 89, $97,116,118,128,132,182,184-$ 185

Littoral Province $\cdot 12-13,74,79,118$, 149, 176

Litumbe, Njoh · 78, 133, 149, 189

London · 28-29, 37, 92, 95, 98, 165, 171,175

London Communiqué · 92, 95, 98

Luma, Martin · 105, 151, 201

\section{M}

Mamfe $\cdot$ 28, 32, 39, 60, 102, 116, 131 marginalisation $\cdot 2,52,67,69,74,77$, $81-82,96,111,115,132,153$

Mbelle, Mbappe $\cdot 113-114$

Mbile, N.N. · 27-28, 30, 43, 60, 118, $177,187,198$

media $\cdot 77,81,101,106,109,121-124$, $128-129,134,136,145,164$

migrant $\cdot 26,132$
MINAT (Ministry of Territorial Administration) $\cdot 123,126$ modernisation · 36, 156, 173, 176, 191

Mukete, Victor · 104, 113, 117-118, 120, 177, 199

Mukong, Albert · 19, 40, 67, 71, 73-74, $78,80,85,94-95,143,152,182$

Muna, Solomon Tandeng · 46, 55, 61, 63, 65-66, 71, 91, 94, 96, 104, 164, 204

Munzu, Simon $\cdot 83,85,88,102,127$, 133, 149, 153, 199

Musonge, Peter Mafany · 111, 115-116, 119-120, 131, 178-179, 186, 189

$N$

national

assembly $\cdot 5,46-47,86,112,164$ integration $\cdot 7,18,69,71,164,193$ unity $\cdot 4,6,20,59,62,66,70,77$, $110,125,150,193,195,205$

nationalism $\cdot 21,23,25$

nationalist

leader $\cdot 12,27$

movement $\cdot 25$

nation-building $\cdot 1,10,36,202$

Ndi, John Fru · 8, 77-79, 99-100, 126, 133-134, 140, 150-152, 197

New Deal $\cdot 11,69,120$

Nfor, Ngala Nfor $\cdot 105,151$

Ngome, Epie · 123, 126-127, 141-144, 194

Nigeria $\cdot 1,10,12-13,15,17-19,23-24$, 26-27, 29-34, 36-41, 49, 57, 64, 77, $98,100,112,143,157,175,194$, 201

North West · 2, 8-9, 11, 13-17, 20, 27$31,38,39,43,60,66,68,74,77-80$, $83,86,100,104,111-112,114-117$, 119, 123-124, 130-133, 135-138, $142,147,149,155,160,165,171-$ 172, 176-179, 181, 184, 186, 190, 198, 200, 203, 206

North West Province · 2, 8-9, 11, 13, $16,27,39,43,66,77,79,100,104$, 
$112-114,123-124,132,135,142$,

$147,149,160,165,176,186,200$

North Westerner · 14-17, 29, 31, 83, 111-117, 119, 136-137, 171-172,

176-178, 186, 190, 206

Northern Cameroons · 12, 23-24, 35, 40

\section{$\boldsymbol{O}$}

OAU (Organisation of African Unity) 19, 105, 200-201

Oben, Peter Ashu · 117, 119-120, 125, $131,133,135$

oil $\cdot 6,64,67-68,89,99,112,128,155$, 173-174, 176-177, 180, 182, 196, 204-205

one-party state $\cdot 59-60,63$

option

ten-state $\cdot 113-114,137,139,206$

two-state $\cdot 110,139$

zero $\cdot 88,92,160$

Owona, Joseph $\cdot 83,87,151,161,167$

$\boldsymbol{P}$

patronage $\cdot 6,7,59,64,68$

PCC (Presbyterian Church in

Cameroon) $\cdot 144,147-148$

peasantry $\cdot 21,176$

plantation $\cdot 14,174-176,179,181$

plebiscite $\cdot 12-13,15,19,22-23,27,31$, 32-34, 36-38, 40-42, 49-50, 66, 141, 194, 203

post-colonial state $\cdot 2,5,8,11,77,108$, 193, 196

Presbyterian $\cdot 144,169$

press $\cdot 85,91,96,98,101-102,121$ -

$122,125,128-130,134,166,170$, 183,188

privatisation $\cdot 162,173-174,177-178$, 180-191, 198

Protestant $\cdot 29$

\section{$Q$}

Quebec $\cdot 82,99,101,207$
RCC (Roman Catholic Church) - 144, 145,147

recolonisation $\cdot 11,72-73,75,140$

referendum · 10, 64-66, 82, 87, 92, 99, $101,109-110,114,155,158,203$, 204

repression · 4, 6-7, 51, 56, 68, 74, 103$104,109-110,133,135-136,143$, 154-155, 197-198

Republic of Cameroon · 3, 33-38, 4042, 44, 48, 50, 55, 72-74, 81, 95-97, 184, 188, 194-196

République du Cameroun · 72, 80, 8892, 95, 98, 103, 107, 114, 143, 151, $153,191,200-201$

reunification $\cdot 2,4,9-10,12-13,15,19$ 20, 22-27, 29-30, 33-38, 40-42, 44, 47-49, 53-55, 59, 62-63, 66, 72, 75, $81,91,95-96,99,106,112,140$, 144-147, 157-158, 163, 176-177, 182, 191, 193-198, 203-205

Roman Catholic $\cdot 144,148,169$

$S$

SAP (Structural Adjustment Programme) $\cdot 8,173,179$

Sawa (see also Grand Sawa Movement) $\cdot 20,118$

SCAC (Southern Cameroons Advisory Council $) \cdot 91$

SCAPO (Southern Cameroons People's Orgnisation) $\cdot 200-201$

SCARM (Southern Cameroons Restoration Movement) · 80, 104105, 199

scholar

Francophone $\cdot 156,206$

SCNC (Southern Cameroons National Council) · 82, 91-96, 98-99, 101$105,113-114,120,-121,129,133$, $135,139,147,149,151-153,158-$ $160,172,183,187,191,198-200$, 202-205 
SCPC (Soutern Cameroons People's Conference) $\cdot 91,93,106,183$

SCYL (Southern Cameroons Youth League) $\cdot 103-105,135,199,203$

SDF (Social Democratic Front) · 8-9, 13, 16, 18, 20, 77-80, 83, 99-101, 104-106, 113, 117-118, 122-125, 133-134, 137, 141, 146-147, 149$153,155,157,159,166,178,181$, 183, 197, 206

secession $\cdot 2,11,17-21,29,32-33,37$, $48,65,76,79,88,94,99,101,103$, 106-108, 110-111, 135, 142, 150, $152,155-156,158-159,161,198$, 202, 204-205

self-determination $\cdot 2,9,76,103,200$ 201

self-government $\cdot 24-25,27,32$

sensitisation · 76, 101-102, 114, 187, 197

separation · $12,30-32,45,49,88-90$, 103, 113, 137, 147, 159, 194, 199, 204-205

settler $\cdot 117,137$

Somali $\cdot 19$

South West · 2, 9, 11, 13-18, 20, 27-32, 38-39, 59-60, 66, 68, 74, 78-80, 83, 86, 102, 111-121, 123-124, 127, 130-133, 136-137, 149, 152, 155, $160,172,174,176-179,181,184-$ 185, 187, 189-190, 198-199, 203, 206

South West Province · 2, 9, 12-13, 27 , $39,74,78-79,83,102,112-113$, $116,118,120-121,124,127,130$, $137,149,155,174,176,179,181$, 184,187

South Westerner · 14-15, 31, 60, 115 $117,119-120,137,152,172,177-$ 178,184

Southern Cameroons · 10-12, 15, 22$50,55,66,72,80-81,84,88-99$, 101-107, 113-114, 128-129, 133, $135,137-139,143-144,149,151-$ $153,160,175,183,190-191,194-$ 195, 199-201, 203-205 student

Anglophone $\cdot 70,77,82,163-165$

Sudan $\cdot 17,19,155$

SWECC (South West Chief's

Conference) $\cdot 17,111-112,118-120$, 187, 190

SWELA (South West Elite

Association) · 9, 17, 111-114, 121, 128, 130, 177, 180, 183-184, 187

$T$

Tabi, Emmanuel Egbe · 113, 115-116, $131,164,169$

TAC (Teachers' Association of Cameroon) $\cdot 80-81,165-172$

Tanzania $\cdot 19$

Togoland $\cdot 27$

trust territory $\cdot 13,25,27,201$

trusteeship $\cdot 25,32-34,37,41,49,60$, $143,175,194$

Tumi, Christian Cardinal · 136, 145 147,153

$\boldsymbol{U}$

UC (Union Camerounaise) · 13, 58-60, 63

unitary state $\cdot 2,8-11,16-18,20-22,36$, $46,48,51,59,62,64-69,71,74-76$, $79,81,83-85,93,101,110-111$, $113,115,139,142,150,152-154$, 156-158, 195, 197, 202, 204, 206

United Kingdom · 10, 27, 92

United Republic of Cameroon · 65-66, 72-74, 81, 196

United States (US) · 79, 86, 106, 124, 160,202

University of Buea $\cdot 111,118,135-136$, 172

University of Yaoundé · 58, 70-71, 77, 103, 163-164, 169

UPC (Union des Populations $d u$ Cameroun) · 4, 12, 26-27, 35, 54, 66, 154-155-160, 194, 197 
Victoria (see also Limbe) $\cdot 14,39,55$, $60,67,73,80,89,97,128,182$, 184-186

W

West Cameroon · 11, 16, 45-48, 51-66, $71,74-75,80,85-86,88,141,143$, $182,195,198-199,205$

West Province · 4, 6, 11-13, 43, 104, $106,112,118,120,130,132,160$, 176
$\boldsymbol{Y}$

Yaoundé · 4, 42-43, 52, 54, 56, 61, 69$72,78,91,94,104-105,109,111-$ $113,115-116,133,141,144-145$, $149,152,165,168-170,178-179$, 184,186

youth $\cdot 4,197,201$ 